UNIVERSIDADE DE SÃO PAULO

ESCOLA DE EDUCAÇÃO FÍSICA E ESPORTE

MODELAGEM ESTRATÉGICO-TÁTICA EM ESPORTES COLETIVOS

DE INVASÃO: APLICAÇÃO AO BASQUETEBOL

LEONARDO LAMAS LEANDRO RIBEIRO

SÃO PAULO

2012 


\section{MODELAGEM ESTRATÉGICO-TÁTICA EM ESPORTES COLETIVOS DE INVASÃO: APLICAÇÃO AO BASQUETEBOL}

\section{LEONARDO LAMAS LEANDRO RIBEIRO}

Tese apresentada à

Escola de Educação Física e Esporte da Universidade de São Paulo, para obtenção do título de doutor em Educação Física.

Área de concentração:

Biodinâmica do Movimento Humano

ORIENTADOR: PROF. DR. CARLOS UGRINOWITSCH

São Paulo 
Autorizo a reprodução e divulgação total ou parcial deste trabalho, por qualquer meio convencional ou eletrônico, para fins de estudo e pesquisa, desde que citada a fonte.

\section{Catalogação da Publicação}

Serviço de Biblioteca

Escola de Educação Física e Esporte da Universidade de São Paulo

Ribeiro, Leonardo Lamas Leandro

Modelagem estratégico-tática em esportes coletivos de invasão:

aplicação ao basquetebol / Leonardo Lamas Leandro Ribeiro. -

São Paulo : [s.n.], 2012.

$197 \mathrm{p}$.

Tese (Doutorado) - Escola de Educação Física e

Esporte da Universidade de São Paulo.

Orientador: Prof. Dr. Carlos Ugrinowitsch.

1. Esporte - Pedagogia 2. Esportes coletivos de invasão 3. Modelagem I. Título. 
Nome: RIBEIRO, Leonardo Lamas Leandro

Título: Modelagem estratégico-tática em esportes coletivos de invasão: aplicação ao basquetebol.

Tese apresentada à

Escola de Educação Física e Esporte da Universidade de São Paulo, para obtenção do título de doutor em Educação Física.

Aprovado em:

\section{Banca Examinadora}

Prof. Dr. Instituição:

Julgamento: Assinatura:

Prof. Dr. Instituição:

Julgamento: Assinatura:

Prof. Dr. Instituição:

Julgamento: Assinatura:

Prof. Dr. Instituição:

Julgamento: Assinatura:

Prof. Dr. Instituição:

Julgamento: Assinatura: 
Ainda que eu fale as línguas dos homens e dos anjos, se não tiver amor, serei como o bronze que soa, ou como o címbalo que retine.

Ainda que eu tenha o dom de profetizar e conheça todos os mistérios e toda a ciência; ainda que eu tenha tamanha fé ao ponto de transportar montes, se não tiver amor, nada serei.

Paulo, I Coríntios 13:1-2. 


\section{AGRADECIMENTOS}

Ao Prof. Dr. Carlos Ugrinowitsch, minha profunda gratidão pela confiança e dedicação, que ao longo dos anos tanto contribuíram para minha formação profissional e pessoal;

Ao Prof. Dr. Junior Barrera, pelo irrestrito suporte para elevar nossas pesquisas ao mais alto nível que possamos atingir;

Ao Prof. Dr. Luiz Dantas, pela amizade e disposição para me ajudar nas mais variadas questões;

Ao Prof. Dr. Valmor Tricoli, por apoiar minhas decisões e estar sempre pronto a ajudar;

Ao Felipe, Edu e Eran, grandes amigos com quem pude compartilhar muitas reflexões e estudos sobre o basquetebol além das habituais piadas;

À turma do Levantamento Olímpico: Carlos, Rene, Marcão, Cora, Maíra, Salomão, Jean, Maria. Especialmente pelas risadas, fundamentais nos dias difíceis;

Ã turma do Laboratório: Hamilton, Barroso, Edu, Mauro (!), Giba, Carlinha, Everton, Anderson, Xuxa (!), Lucas, Ronaldo, Kátia, Saulo, Claudião, por sempre me receberem tão bem;

À FAPESP, por subsidiar esta pesquisa, gerando tantas boas oportunidades acadêmicas;

À minha família, fonte constante de inspiração e amor;

À Vanessa e ao Ariel, que me ajudam a perceber a vida como uma experiência cada vez mais especial; 
SUMÁRIO

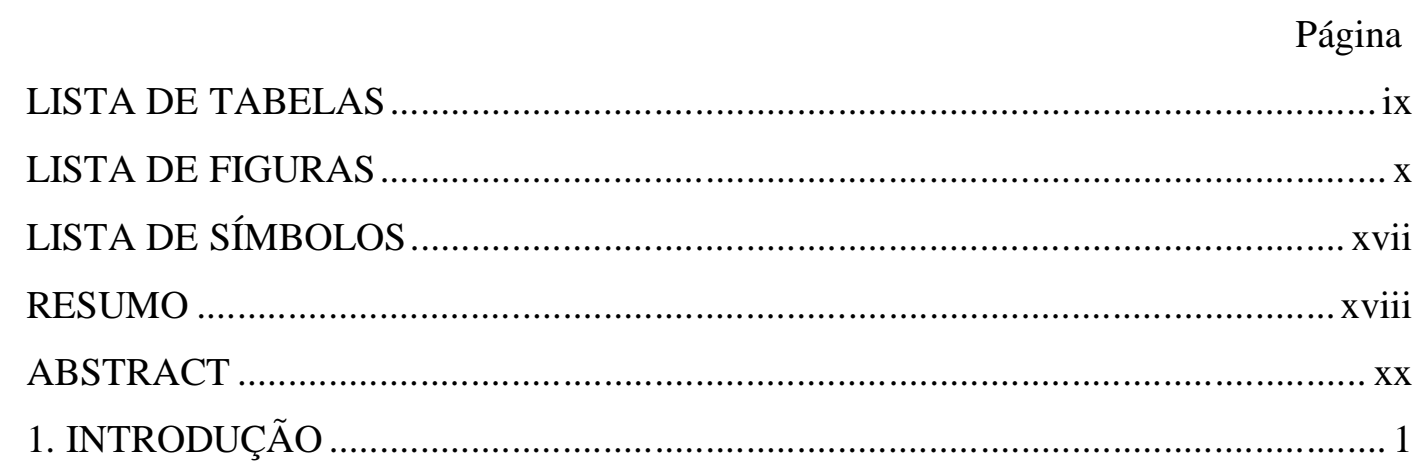

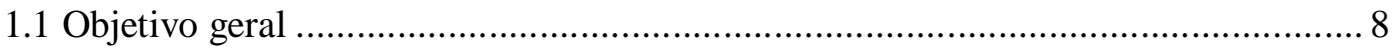

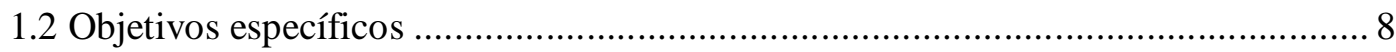

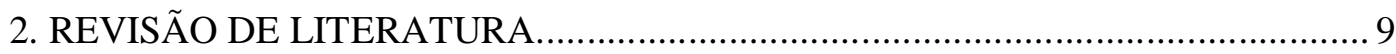

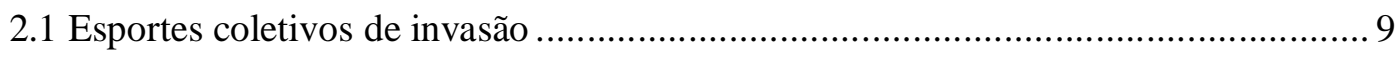

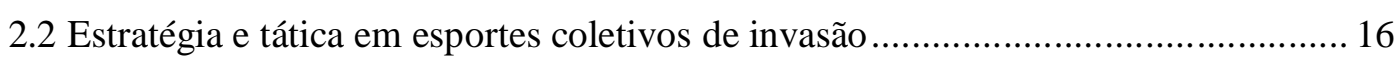

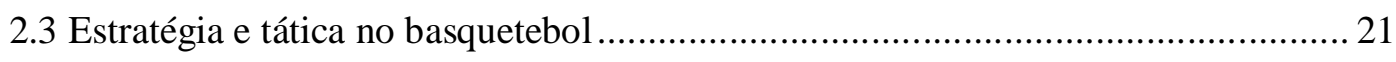

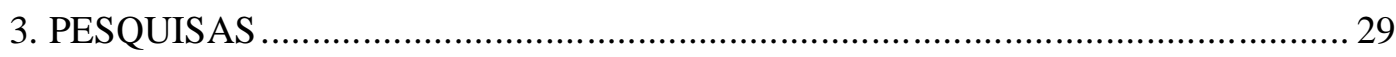

3.1 Modelagem da estratégia em esportes coletivos de invasão ................................29

3.1.1 Controle multi-nível de ação dos jogadores .................................................. 29

3.1.2 Estrutura de representação da estratégia da equipe........................................ 35

3.1.3 Representação paramétrica da estratégia da equipe ......................................... 46

3.1.4 Estrutura dinâmica da estratégia da equipe .............................................. 51

3.1.5 Metodologia hierárquica para desenho de estratégias ...................................... 63

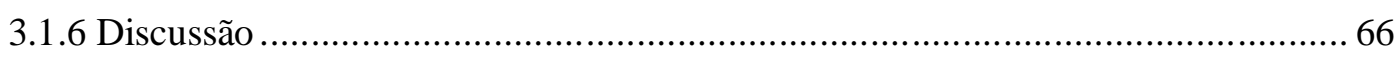

3.2 Modelagem do jogo em esportes coletivos de invasão ..................................... 73

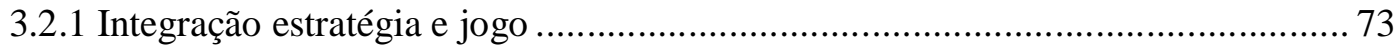

3.2.2 Metodologia de representação da dinâmica do jogo ....................................... 76

3.2.2.1 Linguagem formal de representação dos processos do jogo ……..................... 76

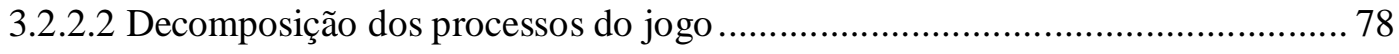

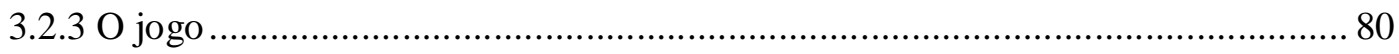

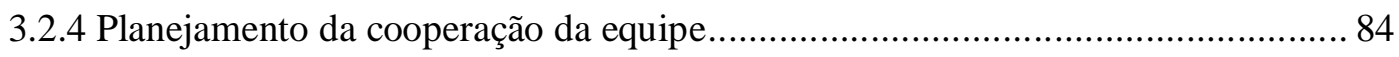

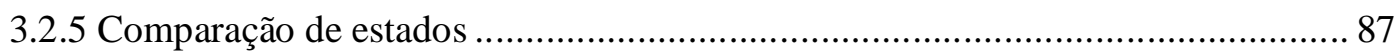




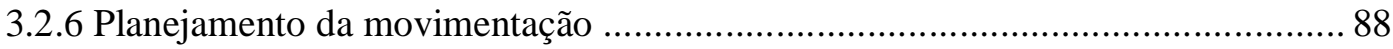

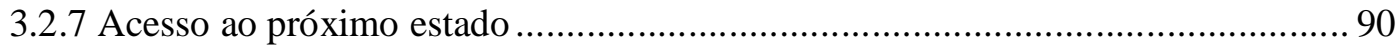

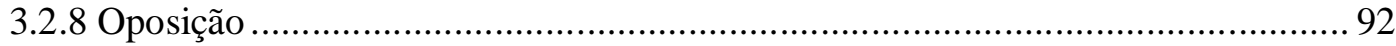

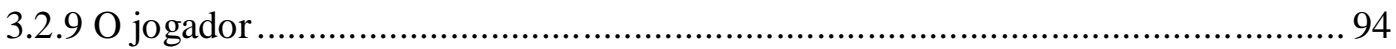

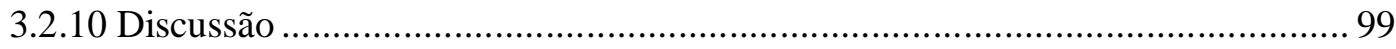

3.3 Classificação das dinâmicas ofensivas e defensivas no basquetebol ..................... 104

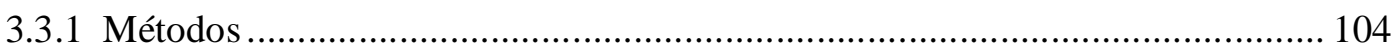

3.3.1.1 Formulação das classes de dinâmicas ........................................................ 105

3.3.1.2 Testagem da reprodutibilidade ......................................................... 106

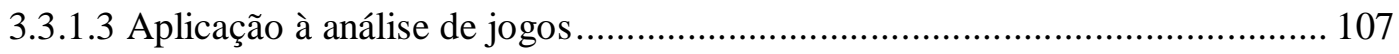

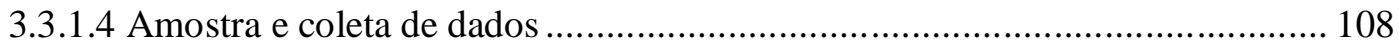

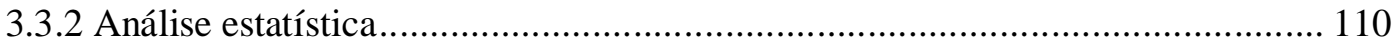

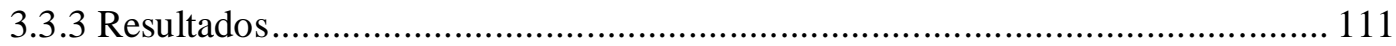

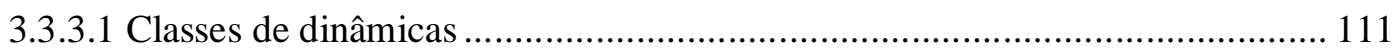

3.3.3.2 Reprodutibilidade intra e inter-observadores............................................ 121

3.3.3.3 Análise ofensiva, defensiva e da oposição entre equipes de basquetebol ........ 122

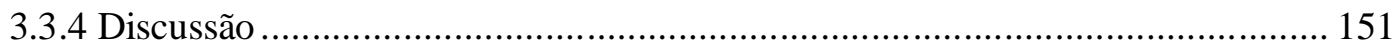

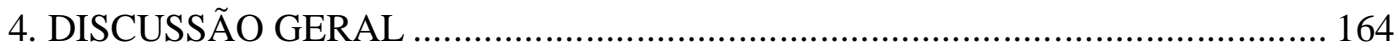

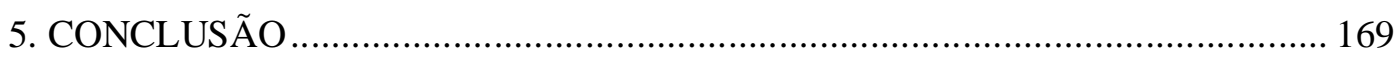

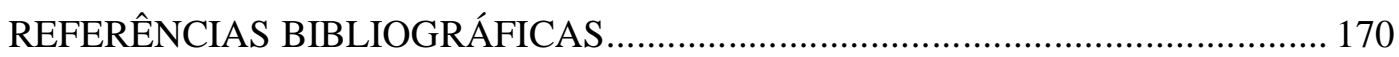




\section{LISTA DE TABELAS}

Tabela 1:Dinâmicas de criação de espaço e as correspondentes dinâmicas de proteção de

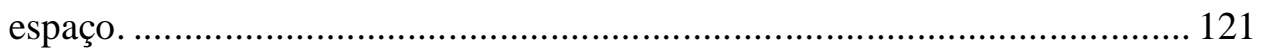

Tabela 2: Coeficientes Kappa intra- e inter-observadores para os critérios de DCEs e DPEs são indicados para três momentos distintos (dia1 x dia2, dia1 x dia3, e $\operatorname{dia} 2 \times \operatorname{dia} 3)$ 122

Tabela 3: Classes de dinâmicas de criação de espaço (DCEs) para as posses de bola que terminaram em oportunidade de finalização, sendo valores expressos em

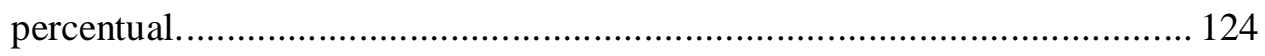

Tabela 4: Valores da análise de correspondência e inércia relativa expressas para cada nível das duas variáveis: dinâmicas de criação de espaço (DCEs) e seleções nacionais. 


\section{LISTA DE FIGURAS}

Figura 1: Estrutura hierárquica em quatro níveis constituintes de um modelo lógico dos ECIs, onde: I: a equipe (i.e., jogadores e comissão técnica), o nível mais alto da estrutura; IIT: a comissão técnica; IIA: grupo de jogadores; IIIT1 to IIITn: membros da comissão técnica; IIIA1 a IIIAn: cada jogador do grupo de jogadores; IVA1a IVAn: sistemas internos de cada jogador (LEBED, 2007).

Figura 2: Categorias táticas de conhecimento sobre o jogo. Adaptado de GREHAIGNE e GODBOUT (1995)

Figura 3: Configuração inicial da ofensiva de triângulos. Onde: setas pretas contínuas indicam deslocamento dos jogadores; setas pontilhadas indicam alternativas de passes, sendo o número de traços transversais nestas setas a indicação da prioridade do passe. Adaptado de WINTER (1962).....................................23

Figura 4: Corte externo de entrada. Figura 4a: Mão-para-mão e penetração; Figura 4b: Mão-para-mão e arremesso; Figura 4c: Mão-para-mão e giro. Onde: setas pretas contínuas indicam deslocamento dos jogadores; setas pontilhadas indicam alternativas de passes, sendo o número de traços transversais nestas setas a indicação da ordem de prioridade do passe; setas pretas com ziguezague indicam deslocamento com drible; seta pontilhada conectada ao aro indica arremesso. Adaptado de WINTER (1962).

Figura 5: Corte duplo sobre o pivô a partir da zona morta (post split off corner pass).

Onde: setas pretas contínuas indicam deslocamento dos jogadores; setas pontilhadas indicam alternativas de passes, sendo o número de traços transversais nestas setas a indicação da ordem de prioridade do passe. Adaptado de WINTER (1962). .25

Figura 6a: Descrição das ações dos jogadores de uma equipe. Figura 6b: descrição das dependências entre jogadores e grupos de jogadores de uma equipe.

Figura 7: Decomposição de um estado em seus elementos, ilustrado por diagramas convencionais de quadras de basquetebol. Onde: a) estado de movimento- 
entrada; b) transformação: b1) deslocamentos; b2) interações cooperativas; c) estado de movimento-saída... 38

Figura 8a: Grafo com estados (En) e conexões entre estados indicadas pelas setas pretas; 8b: Sequência de estados que descreve uma movimentação de uma estratégia no basquetebol. Cada estado é representado por seus componentes: estado de movimento-entrada, transformação (diagramas de deslocamentos e interações cooperativas) e estado de movimento-saída.....41

Figura 9: Uma variação da estratégia ofensiva do basquetebol, a ofensiva em Triângulo, representada por um grafo construído a partir do ESTf, no qual: En designa o nome de um estado em um caminho do grafo. .43

Figura 10: Representação de duas sequências de estados de uma variação da estratégia ofensiva de basquetebol denominada Ofensiva em triângulos, na qual: círculos com números no interior: jogadores; setas pretas: deslocamentos; círculos cinzas: regiões de cada jogador; segundo círculo externo: jogador da bola

Figura 11: Um conjunto de três estados não paramétricos, denotados por $\operatorname{Ek}\left({ }^{-} \mathrm{p}\right)$, sendo k a designação do estado. Um círculo estáa na posição de uma tarefa representada por um índice $\mathrm{i}$ (i.e., $1 \leq \mathrm{i} \leq 3$ ) $\mathrm{de}^{-} \mathrm{p}$. ${ }^{-} \mathrm{p}[\mathrm{i}]$ representa a identificação de um jogador. No quadro intermediário de cada estado, uma seta pontilhada especifica a transformação .47

Figura 12: Um grafo estratégico paramétrico com a inicialização do estado E1(- p) pelos jogadores com as identificações X, Y, Z 48

Figura 13: Sequência de estados de movimento gerada a partir do primeiro estado de movimento. Cada par adjacente de estados de movimento caracteriza um estado do grafo estratégico: A,B,...,I.

Figura 14: Comparação toplógica entre o grafo estratégico (Parte a) e o grafo estratégico paramétrico (Parte b). Na Parte a, os caminhos que partem do nó central em direção aos nós periféricos são destacados. Na Parte b, os caminhos fechados que passam pelo nó central são destacados. .50

Figura 15: Diagrama das fases do jogo, no qual: Defesa X versus Ataque Y (XDef / YAtq); Disputa defensiva $\mathrm{X}$ versus Disputa ofensiva $\mathrm{Y}$ (XDptDef / YDptAtq); Defesa Y versus Ataque X (YDef / XAtq); Disputa defensiva Y versus Disputa ofensiva X (YDptDef / XDptAtq). 
Figura 16: Um grafo que representa uma variação da estratégia ofensiva em triângulos. No qual: $\bigcirc$ - nó inicial; $\bigcirc$ - nó de continuidade; $\bigcirc$ - nó organizador inicial; - nó organizador central; $\mathbf{Q}$ h- nó de decisão; $\mathbf{O}$ - nó de finalização; (ID - nó de disputa....................................................................56

Figura 17: Grafo esqueleto de estratégias ofensivas.....................................................58

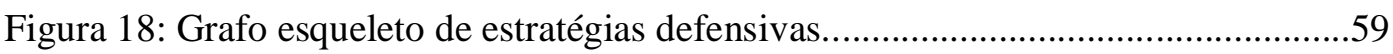

Figura 19: Integração dinâmica dos sub-grafos das fases estratégicas do jogo...............61

Figura 20: Representação da constituição das UESTs pela partição dos jogadores das UESTs e associação da partição dos jogadores com a partição do campo de jogo. 20a) partição das UESTs, 20b) partição do campo de jogo, 20c) ações das UESTs. .64

Figura 21: Um exemplo de partição do campo de jogo, destacando o mapa de interações cooperativas (Figura 21a), a região da bola (Figura 21b) e as ações dos jogadores (Figura 21c).

Figura 22: Representação do sistema controlado composto por dois sistemas dinâmicos discretos (estratégias das equipes A e B) e um sistema dinâmico contínuo (Jogo). As linhas pretas representam o fluxo de controle com retroalimentação. As linhas pontilhadas representam o fluxo de dado do SCESTjogo para o "Planejamento". .75

Figura 23: Processo competitivo em ECIs, com seus fluxos de controle e de dados, nos quais: retângulos são processos, losangos são testes Booleanos, estruturas em formato de papel são dados, setas contínuas são sinais de controle e setas pontilhadas são associações. 78

Figura 24: Representação esquemática da decomposição do "Jogo" em seis níveis hierárquicos. Onde: 1. "Jogo"; 2. "Planejamento da cooperação" (primeiro processo do "Jogo"); 3. "Oposição" (segundo processo do "Jogo"); 4."Comparação de estados"; 5. "Planejamento da movimentação"; 6. "Planejamento do estado". Processos sem legenda não são decompostos no modelo.

Figura 25: Processo "Jogo": fluxos de controle e de dados, nos quais: SC-ESTjogo: Sub-conjunto da estratégia para o jogo; Si-1 e Si: dados referentes aos parâmetros do estado do jogo atual e do estado gerado após a oposição, respectivamente; Ji-1 e Ji: dados referentes à semântica da intervenção do árbitro no momento atual e após a oposição, respectivamente. 
Figura 26: Planejamento da cooperação da equipe: fluxos de controle e de dados, nos quais: Si-1: estado atual do jogo.

Figura 27: Comparação de estados: processos e fluxos de controle e de dados, nos quais: Si-1: estado atual do jogo

Figura 28: Planejamento da movimentação: processos e fluxos de controle e de dados, nos quais: Si-1: estado atual do jogo; SC-ESTjogo: sub-conjunto da estratégia para o jogo.

Figura 29: Acesso ao próximo estado: processos e fluxos de controle e de dados.........91

Figura 30: Oposição: processos e fluxos de controle e de dados. .93

Figura 31: Regra de ação estratégica de alto nível que especifica a execução de um corta-luz. Em 31a, o passe prévio para 5 foi realizado por 1. Em 31b, o passe prévio para 5 foi realizado por 3 .

Figura 32: Modelo da seleção de um gesto esportivo e execução da sua sequência de primitivas por um jogador. 32a): execução da primeira habilidade de movimento básico, 32b): execução da segunda habilidade de movimento básico. No qual: O Percepção; - Decisão. H.E.: Habilidade esportiva; H.M.B.: Habilidade motora básica. .98

Figura 33: a) Desmarque com bola com drible (DBCD); b) desmarque com bola sem drible (DBSD); c) isolamento no perímetro (IPe), d) isolamento interior (II), e) desmarque sem bola (DSB); f) bloqueio direto (BD); g) bloqueio indireto (BI), nos quais: 0 - jogador com bola; $\longrightarrow$ - defensor; - atacante sem bola; $\widehat{W}$ deslocamento com bola; $\longleftarrow$ - finta sem drible; $\longrightarrow$ - bloqueio; $\longrightarrow$ - finalização; região cinza (33c and d) indica uma área vazia ou congestionada por defensores.....................112

Figura 34: DPEs para defesa de DCEs em situações de 1x1 (DBCD, DBSD, IPe): a): neutro, b) orientado para o fundo, c) orientado para o meio

Figura 35: DPEs para defesa do DCE isolamento interior (II), no momento que precede o passe a partir do perímetro: a) neutro; b) 3/4 para cima; c) 3/4 para baixo; d) pela frente.

Figura 36: DPEs para defesa do DCE desmarque sem bola (DSB): a) afastado; b) próximo

Figura 37: DPEs para defesa do DCE bloqueio direto (BD)- defesa do homem da bola: a) por cima; b) pelo meio; c) por baixo; d) inversão; e) troca defensiva; f) dobra defensiva. 
Figura 38: DPEs para defesa do DCE bloqueio direto (BD) - defesa do bloqueador: a) sustentar; b) mostrar; c) afastar; d) abrir; e) troca defensiva; f) dobra defensiva. 118

Figura 39: DPEs para defesa do bloqueio indireto (BI) - receptor do bloqueio: a) por cima; b) pelo meio; c) por baixo; d) inversão; e) trocar; f) dobrar. 119

Figura 40: DPEs para defesa do bloqueio indireto (BI) - bloqueador: a) sustentar; b) mostrar; c) afastar; d) abrir; e) colidir; f) troca defensiva; g) dobra defensiva.

Figura 41: Percentual de ataques posicionais, contra-ataques e interrupções entre equipes nacionais: Australia (AUS), Argentina(ARG), China (CHI), Croacia (CRO), Espanha (ESP), Estados Unidos (EUA), Grécia (GRE), Lituania (LIT) Posicional - PO, contra-ataque -CA, não houve $\mathrm{NH}$.

Figura 42: Percentual de ocorrência das dinâmicas de criação de espaço (DCEs) para cada seleção nacional. BI: bloqueio indireto; BD: bloqueio direto ; DSB: desmarque sem bola; II: isolamento interior; IPe: isolamento no perímetro; DBSD: desmarque com bola sem drible; DBCD: desmarque com bola com drible. AUS: Austrália; ARG: Argentina; CHI: China; CRO: Croácia; ESP: Espanha; EUA: Estados Unidos; GRE: Grécia; LIT: Lituânia.

Figura 43: Análise de correspondência: mapa de simetria com as variáveis seleções nacionais e dinâmicas de criação de espaço, nas quais: ARG: Argentina; AUS: Australia; CHI: China; CRO: Croacia; GRE: Grécia; LIT: Lituania; ESP: Espanha; EUA: Estados Unidos da América. DBCD: desmarque com bola com drible; DBSD: desmarque com bola sem drible; IPe: isolamento no perímetro; II: isolamento interior; DSB: desmarque sem bola; BD: bloqueio direto; BI: bloqueio indireto. 128

Figura 44: Percentual de ocorrência dos tipos de ataque (posicional - PO, contra-ataque - CA, e não houve ataque - NH) em cada categoria etária.

Figura 45: Percentual de ocorrência das dinâmicas de criação de espaço (DCEs) realizadas em posses de bola contra defesa individual. Onde: DBCD: Desmarque com Bola com Drible; DBSD: Desmarque com Bola Sem Drible; IPe: Isolamento no Perímetro; II: Isolamento Interior; DSB: Desmarque sem Bola; BD: Bloqueio Direto; BI: Bloqueio Indireto........130

Figura 46: Percentual de ocorrência das dinâmicas de criação de espaço (DCEs) realizadas em posses de bola contra defesa por zona. Onde: DBCD: 
Desmarque com Bola com Drible; DBSD: Desmarque com Bola Sem Drible; IPe: Isolamento no Perímetro; II: Isolamento Interior; DSB: Desmarque sem Bola; BD: Bloqueio Direto; BI: Bloqueio Indireto........131

Figura 47: Eficiência das dinâmicas de criação de espaço (DCEs) (i.e., frequência de êxitos na finalização decorrente da realização da DCE e a frequência total de ocorrência da DCE) por faixa etária. Onde: DBCD: Desmarque com Bola com Drible; DBSD: Desmarque com Bola Sem Drible; IPe: Isolamento no Perímetro; II: Isolamento Interior; DSB: Desmarque sem Bola; BD: Bloqueio Direto; BI: Bloqueio Indireto.................................................132

Figura 48: Estrutura de decomposição da interação DCE x DPE, a partir da ação dos seguintes jogadores atacantes: i) jogador com bola; ii) receptor do bloqueio; iii) receptor da bola; iv) bloqueador...

Figura 49: Descrição das alternativas de desfecho da oposição para o jogador com bola.

Figura 50: Descrição das alternativas de desfecho da oposição para o receptor da bola

Figura 51: Descrição das alternativas de desfecho da oposição para o receptor do bloqueio.

Figura 52: Descrição das alternativas de desfecho da oposição para o bloqueador....139

Figura 53: Descrição das alternativas de desfecho da oposição quanto às alternativas de finalização.

Figura 54: Percentual dos tipos de ataque (posicionado, contra-ataque, e não houve) para as equipes semi-finalistas e finalistas do campeonato espanhol masculino adulto -2011. Posicional - PO, contra-ataque - CA, e não houve ataque $-\mathrm{NH}$.

Figura 55: Percentual de ocorrência das dinâmicas de criação de espaço (DCEs) realizadas pelas equipes semifinalistas. Onde: DBCDlocal: Desmarque com Bola com Drible sem deslocamento; DCBgarrafão: Desmarque com Bola em direção ao garrafão; DCBfundo: Desmarque com Bola em direção à linha de fundo; DSBlocal: Desmarque sem Bola pela permanência em região sem marcação; DSBcorte: Desmarque sem Bola com corte para região sem defesa; Bdfundo: Bloqueio Direto orientado para o fundo da quadra; Bdgarrafão: Bloqueio Direto orientado para o garrafão; BDhandoff: Bloqueio Direto com passagem da bola de mão para mão; 
BIdentro: Bloqueio Indireto orientado para região interior da oposição; Bifora: Bloqueio Indireto orientado para região exterior da oposição; BIseq: Bloqueio Indireto sequencial. 142

Figura 56: Percentual de ocorrência das dinâmicas de criação de espaço (DCEs) realizadas pelas equipes finalistas. Onde: DBCDlocal: Desmarque com Bola com Drible sem deslocamento; DCBgarrafão: Desmarque com Bola em direção ao garrafão; DCBfundo: Desmarque com Bola em direção à linha de fundo; DSBlocal: Desmarque sem Bola pela permanência em região sem marcação; DSBcorte: Desmarque sem Bola com corte para região sem defesa; Bdfundo: Bloqueio Direto orientado para o fundo da quadra; Bdgarrafão: Bloqueio Direto orientado para o garrafão; Bdhandoff: Bloqueio Direto com passagem da bola de mão para mão; Bidentro: Bloqueio Indireto orientado para região interior da oposição; Bifora: Bloqueio Indireto orientado para região exterior da oposição; Biseq: Bloqueio Indireto sequencial....................................................143

Figura 57:Frequência absoluta das três DCEs e respectivas DPEs mais recorrentes nos dois primeiros jogos semifinais do campeonato espanhol profissional de 2011 e percentual de sucesso no desfecho da oposição........................146

Figura 58: Frequência absoluta das três DCEs e respectivas DPEs mais recorrentes no terceiro jogo semifinal e primeiro jogo final do campeonato espanhol profissional de 2011 e percentual de sucesso no desfecho da oposição.....148

Figura 59: Frequência absoluta das três DCEs e respectivas DPEs mais recorrentes nos dois últimos jogos da final do campeonato espanhol profissional de 2011 e percentual de sucesso no desfecho da oposição. 


\section{LISTA DE SÍMBOLOS}

\section{Atacante com bola}

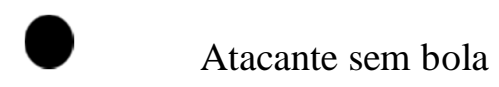

- Jogador de defesa

ר Deslocamento com bola
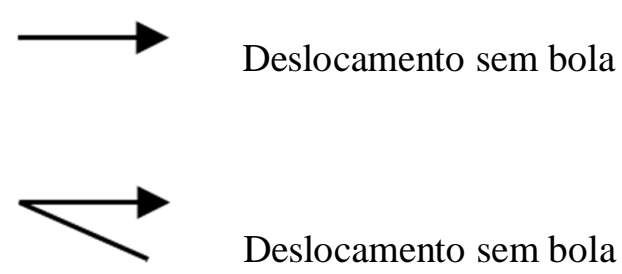

Deslocamento sem bola com mudança de direção

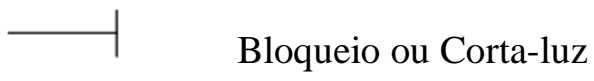

$\longrightarrow$

Finalização à cesta (arremesso ou bandeja) 


\section{RESUMO}

LAMAS, L. Modelagem estratégico-tática em esportes coletivos de invasão: aplicação ao basquetebol. 2012. 197 páginas. Tese (Doutorado) - Escola de Educação Física e Esporte, Universidade de São Paulo, São Paulo, 2012.

O objetivo do presente trabalho foi elaborar um modelo formal de descrição do jogo em esportes coletivos de invasão (ECIs) e instanciar o modelo a um esporte particular, o basquetebol, com a formalização de suas classes de comportamento ofensivos e defensivos. A estratégia foi modelada como um sistema dinâmico discreto. Este modelo tem como elemento lógico fundamental a regra de ação, que descreve as decisões de um jogador. As regras de ação também são usadas para a especificação da transformação de um estado e, consequentemente, da sequência de transformações de estados em um grafo representativo de uma estratégia. As propriedades estruturais, que são requisitos para uma estratégia eficiente, foram introduzidas na modelagem estratégica através de um conjunto de delimitadores (i.e., fases do jogo, tipos de conexões entre os nós por fase, regras de conexão, e regiões estratégicas), que especializam a definição da estratégia excluindo aquelas que não atendem aos requisitos dos delimitadores. $\mathrm{O}$ conjunto restante é denominado modelo da estratégia $\left(\mathrm{EST}_{\mathrm{M}}\right)$. A formalização do $\mathrm{EST}_{\mathrm{M}}$ apresentada neste trabalho estabelece uma metodologia para descrever, desenhar e avaliar a estratégia de uma equipe de um ECI. De maneira integrada à formalização da estratégia, a dinâmica do jogo foi modelada e a relação entre as estratégias desenhadas para duas equipes oponentes e a dinâmica do jogo foi apresentada. As estratégias atuam como bases de dados acessadas para subsidiar as decisões dos jogadores de uma equipe e permitir que eles atuem coletivamente durante as diferentes circunstâncias da oposição. A relação entre as estratégias desenhadas para duas equipes e a oposição no jogo entre estas equipes pode ser formalizada como um caso particular de sistema dinâmico, no qual dois sistemas dinâmicos discretos, representados pelas estratégias das equipes, e um sistema dinâmico contínuo, representado pelo jogo, são integrados por fluxos de controle e dados. Após formalizado o sistema dinâmico que representa a 
relação entre estratégia e oposição, no contexto do jogo, os elementos desse sistema foram decompostos, de forma hierárquica, levando em conta os principais módulos funcionais que compõem o fenômeno. Por fim, é apresentado o processo de validação das classes de comportamentos ofensivos e defensivos do jogo, constituídas por um conjunto limitado de dinâmicas individuais, grupais e coletivas, das quais a comissão técnica pode se valer para elaborar a estratégia da equipe, definir os conteúdos de treinamento, assim como selecionar aqueles, dentre eles, cujo desempenho deverá ser avaliado no jogo. $\mathrm{O}$ modelo proposto constitui uma contribuição original à pedagogia dos esportes coletivos de invasão, tanto pelos avanços imediatos no entendimento das características estruturais desses esportes quanto pelos possíveis desdobramentos tecnológicos, que podem igualmente contribuir no processo de ensino-aprendizado nos mais diversos níveis competitivos.

Palavras-chave: modelagem matemática, pedagogia do esporte, regras de ação, grafo paramétrico, dinâmica do jogo, fluxos de controle, processos. 


\begin{abstract}
LAMAS, L. Strategic and tactic modelling in invasion team sports: application to basketball. 2012. 197 pages. Thesis (Doctorate) - School of Physical Education and Sport, University of Sao Paulo, Sao Paulo, 2012.
\end{abstract}

The aim of this study were: a) to develop a formal model to describe the game in invasion team sports (ITS) and instanciate the model to a particular sport, the basketball; b) to validate classes of offensive and defensive behaviors in basketball. The strategy of ITS was modeled as a discrite dynamics system. This model has as a logical fundamental element named action rules, which describes the decisions of a player. The action rules are used to specify the transformations within a state and, consequently, the sequence of transformations of the states in a graph that representes the strategy of a team. The structural properties, pre-requisetes of an efficient strategy, were introduced in the model through a set of delimeters (i.e. game phases, types of connections between nodes per phase, rules of connections, and strategic regions) that specialize the the definition of strategy excluding those that do not posses the pre-requesites of the delimeters. The remaining set is defined as the strategy model. The strategy model formalized herein stablishes a metodology to describe, draw and evaluate the strategy of an IST team. Furthermore, match dynamics were modeled and integrated to the strategy model. The strategy constitutes a data base which is assessed to support the team pleayer's decisions and allow a collective behavior. The relationship between the strategy and the opposition in a match may be formalized as a particular familty of dynamic systems in which two discrete dynamical systems represented by the two strategies of the opposing teams, and a continuous dynamical system, represented by the match, are integrated by control and data fluxes. Once the model was constituted, its elements were hierarchicaly decomposed, considering the main functional models of the phenomenon. Finally, it is presented the validation process of the possible offensive and defensive behaviors in a match, which are defined by a set of individual, group, and team dynamics. This set of behaviors may be used by the coaching staff to elaborate the 
team strategy, to define the training contents, and to determine how performance is going to be evaluated. The proposed model is an original contribution to the pedagogy of ITSs due to the increased understanding of the structural characteristics of these sports and the possible technological improvements that may be implemented in the teaching process at different competitive levels.

Keywords: mathematical modeling, pedagogy of sport, action rules, parametric graph, match dynamics, control fluxes, processes 


\section{INTRODUÇÃO}

Esportes coletivos de invasão (ECI) constituem uma classe particular de modalidades esportivas cuja disputa é baseada na oposição entre duas equipes, em um espaço comum, com o objetivo principal de pontuar e impedir o adversário de faze-lo, através de ações individuais, grupais e coletivas (GREHAIGNE, BOUTHIER \& DAVID, 1997; HUGHES \& BARTLETT, 2002; LAMES, 2006; LEBED, 2007). A semelhança na estrutura geral de disputa destes esportes, que permite classifica-los conjuntamente como ECIs, impõe a todos a necessidade de um plano de ação, que oriente a atuação coletiva da equipe.

Uma equipe que atua coletivamente visa superar o adversário pela sinergia das ações de seus jogadores, que em conjunto são capazes de ter maior controle sobre as situações ofensivas e defensivas em comparação a outra equipe, que tenha sua atuação centrada em ações individuais (CANNON-BOWERS \& BOWERS, 2006; WARD \& ECCLES, 2006). Para atuar coletivamente no jogo, a equipe deve ser orientada por um plano de ação, o qual dá suporte à necessária coordenação entre as ações dos jogadores (WARD \& ECCLES, 2006). O conjunto de especificações concebidas para dar suporte às ações dos jogadores de uma equipe é definido pelo conceito de estratégia (GREHAIGNE \& GODBOUT, 1995; GREHAIGNE, GODBOUT \& BOUTHIER, 1999; RIERA, 1995). Uma estratégia deve possuir um vasto repertório de opções de comportamentos, que possam gerar incerteza à equipe adversária quanto às suas futuras ações, e produzir assim boas chances de superá-la.

Durante o jogo, uma equipe não é capaz de, constantemente, causar incerteza ao adversário quanto à seu comportamento futuro, pois nem sempre pode atuar de acordo com suas especificações estratégicas. Isso decorre das restrições espaço-temporais mutuamente impostas pela alternância de ações e reações que podem limitar o desempenho da equipe. Nesses momentos, os jogadores são obrigados a promover ajustes individuais ao plano estratégico coletivo para atender às necessidades circunstanciais da oposição. Estes ajustes às circunstâncias da oposição definem o conceito de tática (GREHAIGNE \& GODBOUT, 1995; GREHAIGNE, GODBOUT \& BOUTHIER, 1999; RIERA, 1995). 
Quanto mais completas forem as especificações estratégicas fornecidas aos jogadores, para as diferentes situações do jogo, menos frequentes são as ocasiões em que estes precisam recorrer a decisões individuais, desconectadas da atuação coletiva, para resolver problemas impostos pelo adversário. Porém, nos momentos em que ajustes à oposição são necessários, em circunstâncias não previstas pela estratégia, um bom desempenho tático aumenta as chances da equipe superar o adversário e obter sucesso no jogo.

Atualmente, o desempenho das equipes em diferentes níveis competitivos é influenciado por algumas noções estratégicas e táticas desenvolvidas desde a criação dos ECIs. Por exemplo, no futebol, as noções de sistema de jogo e padrões de circulação da bola estabelecem, respectivamente, uma configuração inicial para os jogadores (e.g., 3:5:2 ou 4:4:2) e os caminhos planejados de progressão com bola (e.g., penetração periférica ou central com a bola) (CARLING, 2011; GREHAIGNE \& CATY, 2010). No basquetebol, a noção de sistemas de ataque e ritmo de jogo estabelecem, respectivamente, o plano de ação coletiva para os ataques posicionais e diversas alternativas para acelerar o jogo em contra-ataques ou retardá-lo em ataques em meia quadra (WINTER, 1962; WOODEN, 1966). Porém, o desenvolvimento histórico do conhecimento vigente sobre os ECIs, que viabiliza o jogo no nível atualmente observado, não foi orientado por métodos científicos, pois uma teoria sobre esportes de invasão e um método para testá-la ainda necessitam ser propostos. $\mathrm{O}$ empirismo que caracteriza o conhecimento sobre os ECIs tem como consequência uma importante limitação, pois a aquisição de novos conhecimentos pelos treinadores ocorre principalmente pelos seus tempos de prática e a transmissão dos conhecimentos se dá mediante tentativas e erros, tornando o processo pouco eficiente. O desenvolvimento de uma teoria que defina os elementos estruturais centrais da competição em ECIs pode proprocionar importantes contribuições à pedagogia desse tipo de esportes.

Alguns autores procuraram dar início à sistematização do conhecimento sobre a relação entre estratégia e os comportamentos observados no jogo descrevendo, qualitativamente, como os jogadores integram a informação originada do jogo com suas expectativas sobre a ação subsequente, no nível individual e coletivo (GREHAIGNE \& GODBOUT, 1995; LAMES \& HANSEN, 2001; LEBED, 2007; MCPHERSON, 2000). Sem detalhar a dinâmica através da qual a integração entre indivíduos ocorre na 
organização da ação coletiva, Lebed (2007) descreveu o contexto em que este processo se dá, através de um esquema no qual as especificações estratégicas globais, geradas pela comissão técnica, são detalhadas e utilizadas pelos jogadores durante a oposição. $\mathrm{O}$ autor destaca assim um importante elemento hierárquico de controle, que delimita as instâncias estratégica (comissão técnica) e tática (jogadores) de atuação.

A questão da eficiência da interpretação das especificações estratégicas geradas e seu uso foi abordada por GREHAIGNE e colegas (1995), valendo-se do conceito de regra de ação. Nesta perspectiva, a regra de ação explica as condições a serem enfatizadas para garantir uma ação eficiente. Ou seja, a partir de um contexto percebido, há uma regra que define a ação que será utilizada (GREHAIGNE \& GODBOUT, 1995). A representação do conhecimento pelos jogadores, com o detalhamento da sua capacidade de interpretar a orientação estratégica e a informação contextual, foi também investigada por McPHERSON (1999a; 1999b). Nestes estudos, a representação do conhecimento dos jogadores foi descrita através da proficiência no uso de planos de ação (i.e., representações armazenadas na memória na forma de rotinas "condiçãoação", segundo as quais há planos de ação definidos para cada contexto) e planos de eventos correntes (i.e., representações atualizadas a partir das modificações contextuais decorrentes dos eventos do jogo, que modificam a condição e podem levar à execução de novo plano de ação). Estas pesquisas demonstraram que o desempenho mais eficiente resulta da habilidade para definir eventos correntes com mais detalhes, o que permite acessar com mais precisão os planos de ação existentes, além de gerar outros mais detalhados.

Embora os estudos de LEBED (2007), McPHERSON (1999a) e GREHAIGNE et al. (1995) delimitem conceitos relevantes, presentes em diferentes níveis da oposição nos esportes coletivos, a identificação de eventuais imprecisões dos conteúdos desses conceitos depende da formalização dessas idéias no contexto mais abrangente de um modelo para a oposição nos ECIs. Além disso, esses conceitos fundamentais ao entendimento da representação do conhecimento no nível do indivíduo devem ser expandidos para o nível coletivo para que se possa compreender como a equipe atua e não apenas o jogador. A formalização desses conceitos em um modelo voltado à representação dos ECIs pode dar suporte à testagem da coerência e precisão dos 
elementos descritos na literatura, assim como sua completude para a representação da oposição no jogo.

A modelagem formal dos conteúdos dos ECIs pode ser auxiliada pelas evidências geradas por estudos dedicados à investigação quantitativa da dinâmica do jogo (DUMANGANE, ROSATI \& VOLOSSOVITCH, 2009; PASSOS, MILHO, FONSECA, BORGES, ARAUJO \& DAVIDS, 2011) e sua relação com a estratégia (BORRIE, JONSSON \& MAGNUSSON, 2002; GREHAIGNE \& CATY, 2010; SEABRA, 2010). Por exemplo, PASSOS et al. (2011) demonstraram a formação de grupos funcionais, constituídos pelas interações entre jogadores quando, em certo intervalo de tempo, estes cooperam para atingir um objetivo comum (e.g., finalizar à cesta no basquetebol). Trata-se de uma evidência sobre a maneira pela qual unidades estruturais de oposição são constituídas, permitindo construir hipóteses sobre o efeito das restrições impostas pelo adversário à execução da especificação estratégica para coordenação dos jogadores no campo de jogo. Em outros estudos (BORRIE, JONSSON \& MAGNUSSON, 2002; SEABRA, 2010), abordou-se a identificação de padrões decorrentes da interação entre os adversários que, segundo as evidências de PASSOS et al. (2011), atuam através de grupos funcionais. Foram verificadas recorrências de padrões (BORRIE, JONSSON \& MAGNUSSON, 2002) além de variações dos padrões entre as equipes (SEABRA, 2010), que diferiram, por exemplo, quanto a maneira de circular a bola no campo. Isto evidencia outro aspecto relevante dos ECIs, a capacidade de estratégias e jogadores distintos apresentarem padrões consistentes e diferentes entre si. Em conjunto, essas evidências experimentais indicam focos relevantes de modelagem.

Ainda, alguns estudos investigaram o perfil das possíveis alterações da frequência de recorrência dos padrões táticos ao longo de um jogo (DUMANGANE, ROSATI \& VOLOSSOVITCH, 2009; KLAASSEN \& MAGNUS, 2001). DUMANGANE e colegas (2009) analisaram os possíveis efeitos de ocorrências anteriores ao êxito em uma posse de bola (i.e., ocorrência de gol) na probabilidade de uma próxima ocorrência do êxito e como o momento do jogo pode afetar esta recorrência. Os autores descobriram que a probabilidade de pontuar ao longo das posses de bola não possui uma estrutura independente e apresenta, em alguns casos, comportamento não-estacionário (i.e., chance de ocorrência do evento varia no tempo). 
Os estudos experimentais apresentados esclarecem sobre o comportamento de elementos relevantes da oposição em ECIs, porém, se valem do estado da arte para a elaboração dos experimentos. Como consequência, embora trate-se de estudos quantitativos, o conhecimento sobre os ECIs que sustenta estas abordagens segue carecendo de construtos que definam sua estrutura com maior precisão. Por outro lado, estudos qualitativos encontrados na literatura sobre os ECIs não foram capazes de estruturar os conceitos apresentados de maneira a constituir um fundamento teórico apropriado para pesquisas experimentais que procurem testar e extender os conceitos estabelecidos sobre o fenômeno (GREHAIGNE \& GODBOUT, 1995; LEBED, 2007; MCPHERSON, 1999a). Logo, o estágio atual do conhecimento sobre ECIs aponta para o desafio científico da elaboração de modelos matemáticos e estatísticos, que permitam, respectivamente, elaborar bases lógicas de uma teoria dos ECIs e utilizar os dados originados dos experimentos para aperfeiçoamento desta teoria. As evidências obtidas nos estudos já realizados indicam que a teoria sobre os ECIs deve ser baseada na formalização do conceito de estratégia e do jogo, sendo o segundo observado no momento no qual duas estratégias são instanciadas na oposição entre equipes adversárias.

A construção de um modelo formal dos ECIs deve ser, de forma inevitável, afetada pelos paradigmas vigentes nas ciências quantitativas. Uma característica singular das técnicas modernas para a investigação de um fenômeno é a disponibilidade de diversas fontes de medida, que produzem uma grande quantidade de dados quantitativos, além de potencial computacional suficiente para processá-los. No contexto dos ECIs, a quantidade de dados disponíveis é elevada. Há uma grande gama de informações qualitativas acumuladas ao longo dos anos pela comissão técnica de uma equipe, que tem à disposição imagens de vídeo bi e tri-dimensionais, de todo o campo de jogo ou parte dele, nos treinos e jogos. Além disso, em muitas equipes são realizadas, sistematicamente, medidas quantitativas de desempenho individuais. Finalmente, veem sendo desenvolvidos pela ciência da computação algoritmos sofisticados para reproduzir diversos aspectos dos ECIs em video-games, indicando uma eminente área de pesquisa inter-disciplinar orientada à simulação do jogo. $\mathrm{O}$ avanço científico na modelagem dos ECIs poderá impactar positivamente a formação e desenvolvimento de treinadores esportivos e, consequentemente, a qualidade do jogo 
apresentado pelas equipes. Por exemplo, a atividade exercida pela comissão técnica de elaboração de estratégias poderá se beneficiar da construção de ambientes computacionais interativos, que possam corrigir ou aperfeiçoar as estratégias desenvolvidas. Já a análise do jogo poderá ser realizada a partir de uma teoria mais consistente, que fundamente a decisão quanto aos conteúdos a serem analisados. Por fim os jogadores, que de forma análoga ao que ocorre com os pilotos da Fórmula-1, poderão se valer de programas de computador que simulem conteúdos do jogo, fornecendo assim subsídios à preparação teórica para uma partida.

A aplicabilidade da modelagem dos ECIs depende da estrutura genérica formalizada ser especializada segundo as características da oposição em cada um dos esportes de invasão. Estas características, que decorrem do regulamento da disputa no esporte, implicam um conjunto particular de comportamentos possíveis, as habilidades motoras executadas no esporte em questão. Neste nível da modelagem, evidencia-se então um problema de taxionomia dos comportamentos do jogo, tornando-se necessário classificar os comportamentos possíveis na oposição em categorias válidas. Estas categorias deverão contemplar tanto as ações individuais quanto as suas diferentes combinações, que geram a grande diversidade de padrões coletivos, ofensivos e defensivos, verificados em um ECI. A classificação dos comportamentos pode ser feita através da definição de classes de equivalência, nas quais são agrupadas ações semelhantes, segundo critérios pré-definidos (LAMAS, DE ROSE JR., SANTANA, ROSTAISER, NEGRETTI \& UGRINOWITSCH, 2011). Por exemplo, no contexto específico do basquetebol, um corta-luz, definido pela sequência padronizada de habilidades motoras empregadas pelos dois jogadores que o realizam, permite a criação de uma classe de equivalência que agrupa todos os tipos de corta-luz.

A definição dos comportamentos especificáveis em um ECI deve contribuir para a investigação dos métodos construtivos das movimentações em uma estratégia. Como consequência, pode dar suporte a pesquisas sobre as maneiras de organizar esses conteúdos em sessões de treinamento e também sobre a inferência dos padrões de comportamento preferenciais nos jogos. Neste último caso é preciso também modelar as possibilidades de desfecho da interação entre ataque e defesa para que se possa analisar a recorrência dos comportamentos levando em conta o sucesso obtido com suas execuções pregressas. Frente à diversidade de aplicações possíveis, a criação de uma 
taxionomia para os comportamentos ofensivos e defensivos do jogo é um elemento central da modelagem dos ECIs no nível especializado de cada um desses esportes.

Nesta perspectiva, os capítulos referentes às contribuições originais deste documento contêm: i) a formalização da estratégia, definindo seus elementos que, integrados, caracterizam o modelo de estratégia da equipe $\left(\mathrm{EST}_{\mathrm{M}}\right)$; ii) a formalização da dinâmica do jogo e sua conexão com a estratégia da equipe; iii) classificação dos comportamentos ofensivos de criação de espaço e defensivos de proteção da meta, e representação dos possíveis desfechos da interação ataque-defesa, no contexto de um ECI particular, o basquetebol. 


\subsection{Objetivo geral}

Elaborar um modelo teórico do jogo em esportes coletivos de invasão e instanciar o modelo a um esporte particular, o basquetebol, com a formalização de suas classes de comportamento ofensivos e defensivos.

\subsection{Objetivos específicos}

a) Formalizar o conceito de estratégia em esportes coletivos de invasão;

b) Formalizar a dinâmica do jogo em esportes coletivos de invasão;

c) Formalizar as classes de comportamentos ofensivos para desequilíbrio da defesa, e defensivos para proteção da meta, no basquetebol;

d) Formalizar os resultados da oposição ataque-defesa no basquetebol, considerando as classes de comportamentos referidas no objetivo $c$;

e) Aplicar a formalização desenvolvida (objetivos $a, b, c, d$ ) na análise do desempenho de equipes em jogos de basquetebol. 


\section{REVISÃO DE LITERATURA}

2.1 Esportes coletivos de invasão

"A atividade esportiva durante o jogo é uma forma particular de atividade humana:compõe-se de um complexo de ações não fortuitas, ligadas entre si por uma unidade de motivação"

(MAHLO, 1969).

Os esportes coletivos são um símbolo presente do passado lúdico e cultural da humanidade (BETRAN, 2001). Na história da humanidade, através de múltiplos jogos coletivos, o homem exercitou a cooperação, a oposição com regras, a constituição de grupos, apredendo a trabalhar em equipe para lograr uma meta comum (BETRAN, 2001). Nestes jogos, a bola foi sempre um meio lúdico versátil, dinâmico e ambivalente, sendo que muitos jogos com bola foram os predecessores dos esportes coletivos atuais. Os esportes coletivos contemporâneos recebem portanto, forte influência de práticas lúdicas ancestrais, adaptadas ao contexto cultural pós-revolução industrial e, em permanente evolução até o presente. Decorre desta evolução histórica ampla gama de esportes coletivos, classificados em classes, segundo características comuns (HUGHES \& BARTLETT, 2002). Uma dessas classes é constituída pelos ECIs, cuja denominação é inspirada no fato do sucesso de uma equipe depender da progressão sobre o campo de jogo adversário até as proximidades da meta adversária, onde realiza um arremesso (e.g., basquetebol), lançamento (e.g., andebol) ou chute (e.g., futebol) com a intenção de pontuar ou adentra a meta do oponente (e.g., rugbi) com o mesmo objetivo.

No contexto dos ECIs, o principal objetivo de uma equipe durante o jogo é coordenar suas ações para recapturar, conservar e mover a bola em direção à zona de finalização e, então, pontuar (BAYER, 1986). Para cumprir este objetivo, cada jogador deve escolher entre suas possíveis respostas (e.g., progredir sem bola, recebê-la, passála, finalizá-la) baseando-se na percepção de si próprio, assim como nas trajetórias dos demais jogadores e da bola, diversas vezes em meio à elevada pressão espaço-temporal.

Devido às diversas alternativas de respostas de cada jogador, decorrentes das orientações estratégicas recebidas e de suas possibilidades técnicas e táticas individuais, além dos possíveis erros de execução decorrentes das retrições espaço-temporais 
impostas pela dinâmica do jogo, os comportamentos apresentados durante o confronto possuem elevada diversidade (MCGARRY, ANDERSON, WALLACE, HUGHES \& FRANKS, 2002). Por isso, para a equipe atuar de maneira coesa é necessário que cada jogador acesse o plano de ação coletivo, definido pela comissão técnica. No plano de ação está contida uma base de conhecimento comum a partir da qual as ações individuais são coordenadas, com o objetivo de maximizar as chances de sucesso frente à oposição. Nos momentos do confronto em que uma equipe é capaz de superar seu adversário, os padrões táticos realizados se aproximam dos padrões especificados no plano de ação. Por outro lado, em momentos do confronto nos quais a eficiência das equipes se equipara, os padrões táticos que emergem da oposição podem não se assemelhar a nenhum dos planejamentos, aumentando a imprevisibilidade do jogo.

A possibilidade de interpretação do jogo a partir dos padrões táticos decorrentes da oposição entre as equipes é empiricamente confirmada pela prática da análise qualitativa e quantitativa dos eventos. Em relação às análises qualitativas realizadas durante ou após o jogo, FRANKS e MILLER (1986) demonstraram que treinadores de alto nível foram capazes de recordar em torno de $42 \%$ dos eventos relevantes. Para superar esta defasagem, é corrente o uso de vídeos de trechos de partidas para aperfeiçoar a interpretação qualitativa do sucesso das movimentações através de grande variedade de quantificações de recorrências de comportamentos nas movimentações realizadas. Porém, a interpretação das recorrências requer a compreensão de suas causas e consequências, o que depende de uma estrutura de análise quantitativa mais complexa que a simples contagem da frequência de ocorrência dos resultados da interação entre as equipes (DUMANGANE, ROSATI \& VOLOSSOVITCH, 2009).

Em uma primeira abordagem do problema, McGARRY e FRANKS (1996) procuraram caracterizar a estrutura competitiva em contextos esportivos com oposição direta ao desenvolver um modelo estocástico de interpretação das sequências de ações de rebatidas da bola (golpes) em partidas de squash. Embora não seja um esporte coletivo, as evidências obtidas no squash, de forma precursora por McGARRY e FRANKS (1996), beneficiaram o entendimento dos ECIs pois a oposição neste jogo tem características dinâmicas comuns às verificadas entre pares de atacante-defensor de jogadores em um ECI e, ao mesmo tempo, constitui um contexto simplificado em relação aos esportes de invasão (BOURBOUSSON, SEVE \& MCGARRY, 2010). 
Os comportamentos modelados por McGARRY e FRANKS (1996) foram avaliados a partir de simulações computacionais. A hipótese geral era que se o desempenho esportivo pudesse ser predito adequadamente, os planos de ação que maximizariam os comportamentos pretendidos poderiam ser identificados e treinados antecipadamente. Na execução da simulação, levou-se em conta o perfil de jogo de cada um dos oponentes em cada partida simulada, considerando seus tipos preferenciais e não-preferenciais de golpes.

A variabilidade de golpes identificados nos padrões de "golpe-resposta" para o jogo simulado foi suficiente para questionar a validade do modelo proposto de predição de golpes futuros a partir de golpes passados. O padrão de seleção de golpes de um jogador tornou-se melhor predito quando o contexto do golpe anterior foi especificado com mais detalhes, por exemplo, em que região da quadra um tipo de golpe selecionado foi realizado. Entretanto, os contextos específicos que propiciaram os padrões mais estáveis variaram entre os jogadores, em função de preferencias individuais, não havendo suporte experimental à caracterização de padrões gerais para toda a amostra. Os resultados sugerem que o valor preditivo da análise do contexto do golpe anterior é importante para o padrão de seleção de golpes entre jogadores de squash mas as respostas estão distantes de propiciar conclusões esclarecedoras sobre planos de ação efetivos no squash ou em esportes mais complexos como os ECIs.

No caso específico dos ECIs, alguns estudos tiveram como objetivo modelar as propriedades dinâmicas da oposição, sob diferentes perspectivas (BORRIE, JONSSON \& MAGNUSSON, 2002; DUMANGANE, ROSATI \& VOLOSSOVITCH, 2009; SEABRA \& DANTAS, 2006; SEABRA, 2010). BORRIE (2002) analisaram a estrutura temporal e a interrelação dos eventos durante jogos de futebol (i.e., padrão-T). A característica definidora do padrão-T foi a ordem fixa dos seus elementos, ocorrendo em intervalos de tempo quase invariantes. O desenvolvimento do algoritmo do padrão-T permite o descobrimento de padrões temporais mesmo que outros elementos ocorram entre aqueles que pertençam ao padrão-T. Diversas recorrências foram identificadas em jogos de futebol, entretanto as possíveis relações causais entre alguns destes padrões recorrentes não foi demonstrada porque o algoritmo aplicado no processo de detecção de padrões não era sensível ao conteúdo tático dos eventos. Ainda, a oposição não foi 
contemplada em nenhuma dessas variáveis, limitando assim as possibilidades de análise.

Já com o foco nos padrões táticos, SEABRA e DANTAS (2010) investigaram recorrências também no futebol. Para tanto, os autores analisaram os padrões de circulação da bola tendo como referência a localização das ações em relação ao posicionamento dos jogadores da defesa. O posicionamento defensivo foi classificado conforme as linhas de defesa constituídas (SEABRA \& DANTAS, 2006). Circulações de bola por regiões do campo delimitadas por linhas defensivas mais próximas ao próprio gol indicavam maior invasão do ataque sobre a defesa adversária. Foi constatado que equipes de nível superior (as finalistas da competição analisada) apresentavam maior ocorrência de padrões de circulação com maior invasão. Assim como foi possível diferenciar equipes nas quais as ações ofensivas concentravam-se pelas zonas centrais da defesa adversária de outras cujos padrões concentraram-se nas laterais e jogo aéreo. Estes resultados evidenciam os nívels de sensibilidade da metodologia proposta para caracterização dos padrões de atuação de uma equipe.

As evidências obtidas por SEABRA e DANTAS (2006), SEABRA (2010) e BORRIE (2002) são elucidadtivas quanto à demonstração quantitativa de padrões existentes na dinâmica do jogo. Porém, devem ser complementados pela investigação de dois aspectos fundamentais para o entendimento dos ECIs. Primeiro, a análise de todos os jogadores no campo de jogo através de dados posicionais de todos eles. Como a anotação da dinâmica de todos os jogadores em campo pode consumir muito tempo ou mesmo ser inviável, a aquisição de dados costuma limitar-se aos jogadores próximos à bola. Isto limita a interpretação da oposição por não dar acesso ao comportamento coletivo de toda a equipe. Segundo, a influência dos eventos anteriores e do momento do jogo na probabilidade de ocorrência dos eventos futuros, definidos, respectivamente, como as hipóteses da dependência e de estacionariedade.

KLAASSEN e MAGNUS (2001) obtiveram evidências sobre as hipóteses de dependência e estacionariedade em um esporte de oposição individual, o tênis de campo. De acordo com estes autores, a influência das ações anteriores na probabilidade de pontuar pode ser detectada por comportamentos não-estacionários dos resultados dos golpes. As evidências obtidas por KLASSEN e MAGNUS (2001) motivaram a investigação de DUMANGANE, ROSATI e VOLOSSOVITCH (2009) no contexto dos 
ECIs. Os autores partiram de uma hipótese segundo a qual no jogo parece haver momentos nos quais um padrão tático com maior taxa de sucesso recorre mais que em outros momentos. Em jogos de andebol, os autores verificaram que a probabilidade de pontuar ao longo das posses de bola de um jogo não possui uma estrutura independente, ou seja, o exito ou fracaso na tentativa de pontuar nas posses anteriores influi no resultado da posse presente. Além disso, os autores identificaram, em alguns casos, comportamento não-estacionário, ou seja, a frequência de ocorrência do êxito não foi estável durante todo o jogo. Apesar destes pesquisadores terem investigado a hipótese da estacionariedade em ECIs, eles não consideraram os padrões táticos apresentados pelas equipes e analisaram apenas o produto final das posses de bola, ou seja, ter sido, ou não, marcado o ponto. A análise das hipóteses da dependência e estacionariedade parece ser um caminho adequado para a compreensão da causalidade dos eventos do jogo porém, estas devem ser investigadas no contexto de recorrência dos padrões táticos coletivos.

De forma complementar aos estudos experimentais que abordam sob diversas perspectivas os padrões táticos do jogo e suas causas, verificam-se esforços teóricos preliminares de modelagem dos elementos competitivos dos ECIs (LAMES \& HANSEN, 2001; LEBED, 2007). LEBED (2007) discute um modelo genérico construído em duas etapas: i) elaboração lógica, ii) elaboração matemática. É apresentada uma versão preliminar da etapa lógica, composta por quatro níveis hierárquicos (Figura 1).

$\mathrm{Na}$ interpretação dada pelo autor para o esquema representado na Figura 1, o elemento central à compreensão da estrutura dos ECIs é a equipe, composta por comissão técnica e jogadores, e que corresponde ao nível hierárquico mais elevado do modelo. A decomposição da equipe é representada pela relação entre a comissão técnica (IIT) e o jogadores (IIA), que constituem o segundo nível do modelo, e caracteriza a orientação aos jogadores sobre as ações a serem empregadas no jogo. Dois grupos, sendo um deles composto pelos membros da comissão técnica (IIIT) e o outro por cada um dos jogadores da equipe (IIIA 1 a IIIA $_{n}$ ) compõem o terceiro nível do modelo. Neste nível são processadas as informações trocadas entre comissão técnica e grupo de jogadores, indicada pelos sinais de controle entre estes grupos, na Figura 1. Este é um aspecto interessante do modelo pois, embora não explicitado, aponta para uma relação 
de controle da comissão técnica, denotando que as ações realizadas no jogo são influenciadas por esta. O quarto e último nível representa os sistemas internos (e.g., as características psíquicas e fisiológicas) relacionadas ao desempenho de cada jogador (IVA).

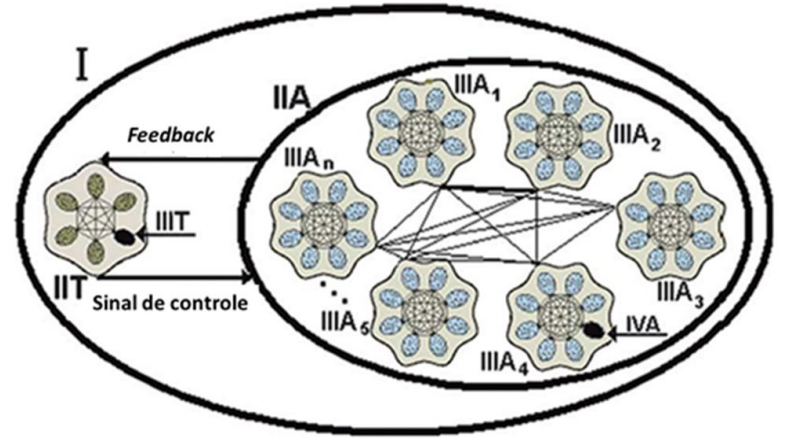

Figura 1:Estrutura hierárquica em quatro níveis constituintes de um modelo lógico dos ECIs, onde: I: a equipe (i.e., jogadores e comissão técnica), o nível mais alto da estrutura; IIT: a comissão técnica; IIA: grupo de jogadores; IIIT1 to IIITn: membros da comissão técnica; IIIA1 a IIIAn: cada jogador do grupo de jogadores; IVA1a IVAn: sistemas internos de cada jogador (LEBED, 2007).

A proposta de Lebed, embora preliminar, aponta para o desenvolvimento de uma teoria dos ECIs, na qual todos os demais estudos apresentados podem ser contextualizados. Para tanto, o entendimento da competição nos ECIs requer um esforço de mapeamento do jogo real em uma representação formal e mais abstrata de seus elementos (BEETZ, KIRCHLECHNER \& LAMES, 2005). Um modelo da competição em ECIs, por definição, implica uma simplificação do fenômeno, por incapacidade de apreender toda a sua complexidade. Porém, é uma maneira de se ampliar a compreensão a seu respeito, desde que a partir do modelo formulado não sejam produzidas consequências teóricas contrárias ao que se encontra na realidade.

A exemplo do que ocorre para a solução de problemas e avanço do conhecimento em outras áreas da ciência, a formalização dos conteúdos associados aos ECIs constitui o fundamento teórico para que, no futuro, o modelo desenvolvido possa ser reproduzido em programas de computador para checagem de sua precisão. A interface computacional poderá permitir simular jogos e através da interpretação dos 
resultados testar a eficiência de conteúdos inerentes à competição em ECIs (e.g., a estratégia de uma equipe), cuja eficiência não pode ser cientificamente avaliada atualmente por ausência de suporte teórico adequado.

A modelagem de qualquer fenômeno deve levar em conta suas características para que a melhor abordagem de formalização de seus conteúdos seja selecionada. No caso dos ECIs, sua estrutura pode ser caracterizada como um sistema controlado por retroalimentação (OGATA, 1986). A idéia de um sistema controlado é ilustrada pelo funcionamento de um termostato. O uso deste aparelho implica o objetivo de manutenção de uma certa temperatura em um dado ambiente. Para tanto, há uma entrada externa (i.e., referência) que informa a temepartura alvo e um módulo de controle emissor de um sinal, que comanda a operação de aumento ou diminuição da temperatura no ambiente (i.e., sistema controlado). A variação resultante da temperatura retroalimenta o controle, que compara o sinal recebido do sistema controlado com o da referência externa e recalcula seu comando, mantendo dessa forma a temperatura planejada. Nos ECIs, o objetivo de cada uma das equipes é seguir o planejado pelas respectivas estratégias. Para tanto, as estratégias das duas equipes são modeladas como duas entradas externas (i.e., referências) cujo sinal é enviado para os agentes de decisão de cada uma das equipes (i.e., controles) que no jogo são os prórprios jogadores. Então, os jogadores fazem a interpretação do contexto, comparam-no com a especificação estratégica e planejam a próxima ação. A execução da ação na oposição entre as equipes configura o sistema controlado, enquanto o resultado da interação entre as equipes constitui a informação que retorna como feedback para os jogadores das equipes. Nos capítulos 3 e 4 os elementos que constituem o modelo formal do processo competitivo em ECIs serão apresentados. A possibilidade de modelar os ECIs a partir da teoria do controle favorece a investigação científica do fenômeno por vincular a análise de um problema original à uma teoria consolidada com metodologia experimental já desenvolvida.

A partir da formalização da competição nos ECIs será possível investigar a precisão e consequências da frase descrita na epígrafe deste capítulo (MAHLO, 1969), segundo a qual o jogo "compõe-se de um complexo de ações não fortuitas, ligadas entre si por uma unidade de motivação". Ao mencionar "ações não fortuitas" há uma indicação de planejamento prévio das ações. Ainda, em "ligadas entre si por uma 
unidade de motivação" há a indicação da capacidade desse planejamento prévio para coordenar as ações individuais de maneira a gerar um comportamento coletivo. Evidencia-se com isso um importante objeto de estudo, a estratégia e sua operacionalização no jogo através da tática. Por este motivo, estes conceitos serão detalhados na próxima sub-seção.

2.2 Estratégia e tática em esportes coletivos de invasão

Algumas características fundamentais dos ECIs, tais como haver um grupo de indivíduos (i.e., comissão técnica) que especifica as ações a serem executadas por outro grupo (i.e., jogadores), em um contexto competitivo, no qual estão em disputa interesses opostos, precede e transcende o contexto do esporte. As regras organizacionais que regem contextos desta natureza advém dos meios militares e seu conteúdo, desenvolvido aos longos dos séculos, é definido por dois conceitos centrais: estratégia e tática (RIERA, 1995; SAMPEDRO, 1999). A palavra estratégia deriva do grego stratègós (de stratos, exército, e ago, liderança), significando a arte do general. E a palavra tática, de origem também grega, deriva de taktikeé, advinda do verbo tasso, que significa organizar as tropas (SAMPEDRO, 1999; RIERA, 1995). Segundo SAMPEDRO (1999), o surgimento destes conceitos é comumente vinculado à Grécia antiga porque nesta região e época parecem ter ocorrido as primeiras contribuições sistemáticas na área da organização de um exército em combate, com o advento das primeiras formações racionais no campo de batalha.

Atualmente, há atividades de diferentes naturezas nas quais uma estratégia orienta o curso das ações (i.e., tática) de grupos de indivíduos em contextos competitivos. Nos ECIs a elaboração de uma estratégia que oriente a tática dos jogadores de uma equipe constitui uma prática frequente, em função das semelhanças desta atividade esportiva com as circunstâncias de uma batalha. Os ECIs caracterizamse, por exemplo, pelo esforço para a dominância territorial (THORPE, BUNKER \& ALMOND, 1986). Além disso é necessário que os jogadores e a bola progridam até a meta adversária, ou ao menos até suas proximidades, como ocorre respectivamente, no rugbi e no futebol de campo, com o objetivo de pontuar (THORPE, BUNKER \& ALMOND, 1986). Assim, como em uma batalha, define-se um contexto no qual a 
oposição dos objetivos impõe a necessidade de elaboração estratégica e eficiência na tática para aumentar a chance de êxito na disputa.

Em qualquer ECI a estratégia possui objetivos e conteúdos distintos no longo, médio e curto prazos (RIERA, 1995). No longo prazo, diz respeito à concepção da maneira de jogar da equipe em um macrociclo (i.e., temporada completa) e à definição de conteúdos dos mesociclos (i.e., fases intermediárias de preparação). No médio prazo, diz respeito à delimitação da maneira de jogar da equipe contra o próximo adversário e à consequente definição do conteúdo de um microciclo (i.e., semana de treinamento). No curto prazo, diz respeito às instruções dadas à equipe durante o intervalo do jogo ou durante um tempo técnico no meio do jogo.

Em qualquer das instâncias temporais apresentadas, o objetivo da elaboração de uma estratégia é organizar a atuação da equipe. Para tanto, a estratégia elaborada deve ser eficiente em prover à equipe elementos para lidar com três problemas fundamentais da oposição: i) espaço-temporais; ii) de comunicação; iii) organizacionais (GREHAIGNE \& GODBOUT, 1995).

Para responder de forma efetiva aos problemas espaço-temporais no jogo, a estratégia dever ser concebida de maneira a orientar a equipe atacante para que esta seja capaz de, individual e coletivamente, conservar a bola e organizar-se para superar o adversário e finalizar. Da mesma forma, a equipe defensora deve impor restrições à progressão ofensiva, recuperar a bola ou, ao menos, forçar finalizações menos favoráveis para o ataque.

Em relação à organização, a partir de seu planejamento, uma equipe deve ser capaz de produzir incerteza nos adversários a partir das múltiplas alternativas de comportamentos a serem realizados, que apenas os membros da própria equipe têm conhecimento. Quanto mais opções, maior a incerteza. Porém, as decisões que levam a uma alternativa de comportamento ou outra devem ser de conhecimento comum entre todos os jogadores da equipe, havendo a certeza da ação futura ocorrer de forma coletiva. A redução da incerteza para uma equipe em posse da bola depende da qualidade dos códigos de comunicação da mesma, que permitem fazer escolhas compreensíveis por todos os jogadores.

Por fim, a organização da equipe deve prever que os jogadores, a partir da atuação individual, tenham orientação sobre como construir a atuação coletiva. Assim, 
uma equipe deve aumentar sua ordem interna através de ações coordenadas enquanto procura diminuir a ordem da equipe adversária. Diminuir a ordem interna da equipe adversária significa prevalecer estrategicamente sobre ela. Uma estratégia eficiente enseja o uso adequado da posse de bola para obter alternativas de finalização através da incerteza causada no adversário pela coerência entre ações individuais e coletivas.

Uma estratégia bem desenhada deve também ser adequadamente operacionalizada. Para tanto, é necessário desenvolver o que GREHAIGNE e LAROCHE (1994) definiram como conhecimento tático. Este conceito foi definido pelos autores a partir da inferência de regras de ação no jogo declaradas por jogadores e treinadores, as quais foram categorizadas em um processo de validação que levou em conta a relevância das mesmas. Foram assim evidenciadas três categorias táticas de conhecimento sobre o jogo: i) regras de organização do jogo; ii) regras de ação; iii) capacidade de intervenção ${ }^{1}$.

As regras de organização do jogo definem um conjunto de conhecimentos sobre elementos como a lógica do jogo, as dimensões da área de jogo, a distribuição dos jogadores no campo de jogo e a diferenciação de tarefas dos jogadores (GREHAIGNE, BILLARD, GUILLON \& ROCHE, 1988). Os autores não apresentam exemplos de formulação das regras mas ilustram como elas induzem padrões gerais de comportamentos individuais e coletivos dos jogadores. Por exemplo em ECIs cuja meta é um gol (e.g., hoquei, futebol de campo), o formato da meta é um aspecto que influi na organização do jogo, induzindo os defensores a manterem o eixo central protegido para distanciar os atacantes do centro do ataque, por esta região ensejar finalizações de posições mais favoráveis. Ainda, entre o futebol de campo e o hoquei, o número de jogadores, as dimensões do campo de jogo e as possibilidades técnicas de manipulação da bola geram restrições espaço-temporais específicas a cada um dos esportes.

O conceito de regra de ação é apresentado, qualitativamente por GREHAIGNE e GODBOUT (1995) como sendo um elemento estrutural uilizado no desenho de

\footnotetext{
${ }^{1}$ No texto original, capacidade de interveção é referida como capacidades motoras. Porém, ao menos no idioma português, capacidades motoras nomeiam um construto bem definido e com sentido diverso do apresentado pelo autor. Para fins de precisão, o termo foi substituído.
} 
estratégias. Segundo o autor, uma regra de ação define condições a serem enfatizadas e elementos a serem levados em conta para uma ação eficiente, sendo fundamentais para o conhecimento tático do jogo. Seu uso, isolado ou conectado a outras regras, fornece uma resposta a um dado problema. Por exemplo, para criar espaço uma equipe deve adiantar a defesa em uma direção e rapidamente passar a bola em outra direção. Conjuntos de regras de ação relacionadas caracterizam princípios de ação (GREHAIGNE \& GODBOUT, 1995). Princípios de ação constituem referências macroscópicas que permitem ao treinador e, eventualmente ao jogador, isolar e classificar fatos importantes da oposição, por exemplo, "jogar em movimento para levar a bola à zona de pontuação e finalizar" (GREHAIGNE et al., 1988). A seguir é apresentada uma lista de princípios de ação e regras de ação relacionadas.

Para o princípio de ação "jogar em movimento", estão relacionadas regras de ação, tais como: reduzir o tempo para que a bola alcance a área de finalização; favorecer passes rápidos, mantendo-se em movimento após se desfazer da bola, etc. Para "criar espaço": usar a largura e profundidade do campo de jogo; restringir os defensores a uma região do campo de jogo e atacar por outra, etc. Para "defender a meta": manter quantos jogadores for possível entre a bola e a meta; manter a equipe organizada em linhas de força e planejar suas reposições, etc. Para "recuperar a posse da bola": aumentar o número de jogadores na metade do campo de jogo e ataque; colocar pressão imediata no jogador com a bola, etc. Apesar das regras de ação descritas por GREHAIGNE e BILLARD (1988) serem concebidas de forma genérica, até onde nos foi dado conhecer não há estudos que tenham se dedicado a especializar as regras de ação à um ECI particular. A formalização da noção de regras de ação será apresentada e também exemplificada no terceiro capítulo deste documento.

Por fim, a capacidade de intervenção refere-se ao conhecimento sobre duas categorias de problemas do jogo: percepção-decisão dos jogadores e habilidades motoras que os jogadores devem executar. Por exemplo, para um jogador em controle da bola responder a uma linha de passe criada por um companheiro, o segundo deve estar no campo de visão do primeiro e a uma distância compatível com a execução do passe. A relação entre regras de organização, regras de ação e capacidade de intervenção é representada na Figura 2 (GREHAIGNE \& GODBOUT, 1995). 


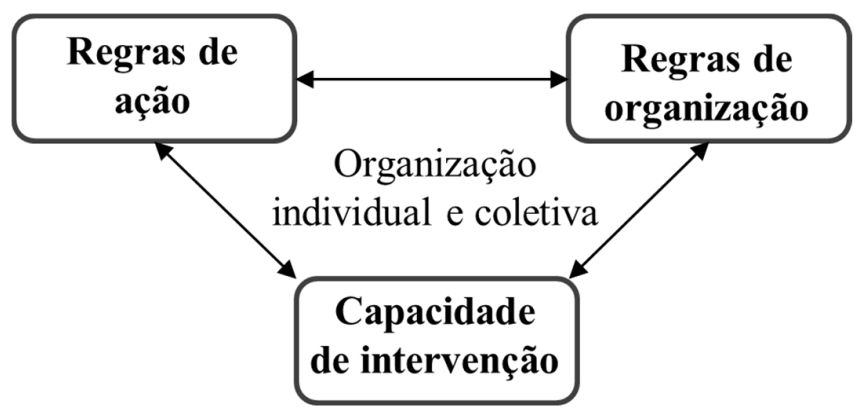

Figura 2: Categorias táticas de conhecimento sobre o jogo. Adaptado de GREHAIGNE e GODBOUT (1995).

As três categorias táticas de conhecimento sobre o jogo apresentadas (i.e., regras de ação, regras de organização e capacidade de intervenção) produzem uma noção qualitativa da organização individual e coletiva no jogo. Em complemento à estas abordagens que procuram contemplar todo o universo do jogo, alguns estudos experimentais investigam problemas delimitados dentro desse universo, como o conceito de agrupamentos funcionais (PASSOS, ARAUJO, DAVIDS, GOUVEIA, MILHO \& SERPA, 2008; PASSOS et al., 2011). Segundo este conceito, jogadores das duas equipes tem seus comportamentos influenciados pelo oponente caracterizando processos emergentes das relações espaço-temporais estabelecidas no jogo. Sua compreensão contribui para a ampliação da teoria sobre a tática em ECIs pois ajuda a esclarecer a maneira pela qual jogadores interagem entre si.

PASSOS et al. (2008) diferenciam dois parâmetros reguladores dos grupos funcionais: distância entre jogadores e velocidade relativa entre eles. Velocidade relativa foi definida como a diferença entre a velocidade de corrida em linha reta de um atacante e um defensor em um dos agrupamentos constituídos. Na relação inter-equipes no rugbi, considerando um par de adversários, o atacante impõe restrições à ação do defensor pela modulação de sua velocidade. Com isso, cria flutuações da sincronia com seu oponente, desestabiliza a relação entre eles e se beneficia da instantânea vantagem espaço-temporal. Na relação intra-equipe, verificou-se tendência dos agrupamentos em sub-unidades funcionais da equipe serem sensíveis à diferentes modulações do contexto, tal como posicionamento relativo ao defensor mais próximo.

A partir dos estudos apresentados evidencia-se o aspecto complementar do conhecimento produzido sobre estratégia e tática nos ECIs (GREHAIGNE \& 
GODBOUT, 1995; PASSOS et al., 2008; PASSOS et al., 2011). A estratégia de uma equipe condiciona, em certa medida, os comportamentos apresentados na oposição, e a tática a complementa, contribuindo para sua implementação. Dessa forma, o conteúdo exposto pode ser generalizado como uma contribuição para a compreensão do planejamento e execução da coordenação entre os jogadores da equipe. Logo, a formalização dos conceitos de estratégia e tática nos ECIs também deve fazer parte do esforço de modelagem do conteúdo desses esportes.

Na próxima sub-seção, os conceitos aqui definidos serão aplicados a um ECI particular, o basquetebol. Será apresentada a heurística empregada no desenvolvimento da estratégia neste esporte, as características atuais do conhecimento empírico sobre o fenômeno e uma proposta metodológica de classificação dos possíveis comportamentos no jogo.

\subsection{Estratégia e tática no basquetebol}

A estratégia no basquetebol é um campo de conhecimento empírico em constante transformação. É frequente o surgimento de novas combinações de ações ofensivas e defensivas de jogo e a heurística empregada ao longo das décadas de existência do esporte para desenvolvimento do que hoje se conhece foi documentada em dois estudos (BETRAN \& CAMÍ, 1993, PHILLIPS, 1990). Esta evolução será aqui abordada, de forma sintética, seguindo os períodos cronológicos adotados por BETRAN (1993). Este autor considera cinco fases principais de evolução do jogo, conforme o aumento da complexidade estratégica. As informações de PHILLIPS (1990) serão alocadas conforme as fases de BETRAN (1993), de maneira a complementar os dados do primeiro.

A primeira fase compreendeu o período entre 1891 e 1913. O ataque era constituído por uma composição entre um contra-ataque não estruturado sucedido por um jogo de 5x5 na meia-quadra, com exígua diversidade estratégica. A única função especializada de jogo era a do arremessador de lances-livres. Na defesa, havia uma única estratégia, a defesa individual. A segunda fase compreendeu o período entre 1914 e 1945. No ataque, foi estabelecida a função do pivô e desenvolveu-se o conceito de pass-and-go (i.e., passar a bola e desmarcar-se com um deslocamento em velocidade, 
muitas vezes em direção à cesta) e suas variações. Na defesa, surgem os conceitos de flutuação e ajuda defensiva na dinâmica coletiva da defesa. A terceira fase compreendeu o período entre 1946 e 1959. Observa-se grande desenvolvimento da condição física dos jogadores, e com isso, a dinâmica do jogo no ataque e na defesa se modificaram. No ataque, aumentou a variedade de especificações estratégicas para ações dos jogadores distantes da bola (i.e., jogo sem bola). Na defesa, foi difundida a marcação por toda a quadra com dobras defensivas (i.e., dois jogadores defendem, momentaneamente um atacante). A quarta fase compreende o período entre 1960 e 1976. No ataque, as estratégias evoluíram para movimentações sem solução de continuidade, através de dinâmicas que se desenvolviam, de forma simétrica, nos dois lados da meia quadra ofensiva sem, necessariamente precisarem ser interrompidas (e.g., Triângulo, Shuffle, Flex). Na defesa, surgem as integrações dos sistemas individual e zona, gerando as defesas combinadas, organizadas segundo elementos estratégicos tanto de defesas individual quanto zona. A quinta fase compreendeu o período entre 1977 e 1993. Diferente das fases anteriores, caracterizou-se pela integração das estratégias destinadas à cada fase do jogo (i.e., defesa, transição ofensiva, ataque e transição defensiva) indicando a importância crescente do ritmo de jogo e, por isso, a preocupação em estruturar o ataque enquanto ainda se estava na defesa e vice-versa. Ainda, a criação da linha dos três pontos teve um importante impacto estratégico. Induziu a defesa a expandir sua zona de atuação, liberando mais espaço para o ataque na região próxima à cesta, assim como aumentaram as ações ofensivas para finalização na periferia do ataque, próximo à linha dos três pontos.

De 1993 em diante verificou-se a crescente importância das transições ataquedefesa e defesa-ataque devido ao aumento da velocidade do jogo, que por sua vez foi influenciada pela diminuição do tempo de posse de bola (KRAUSE \& PIM, 2002). Na sequência, serão detalhados os aspectos básicos de uma das mais bem-sucedidas estratégias ofensivas contemporâneas, a ofensiva em triângulos (WINTER, 1962). Este detalhamento visa propiciar melhor entendimento das características práticas de uma estratégia no basquetebol.

Em sua configuração inicial, após a chegada ao ataque, três jogadores se posicionam em metade da meia-quadra ofensiva, constituindo os três vértices de um triângulo, enquanto na outra metade da quadra, são posicionados os outros dois 
jogadores (Figura 3). A estratégia preconiza o espaçamento constante entre os jogadores atacantes em 5 a 6 metros entre si para dificultar as ajudas defensivas, além da manutenção de quatro linhas de passes para o homem com bola pela movimentação coordenada dos demais jogadores. A coordenação das movimentações ocorre a partir de regras de ação especificadas para cada jogador a partir da posição da bola e dos demais jogadores em quadra (atacantes e defensores). Nestas movimentações o triângulo lateral pode ser reconstituído, se necessário, nos dois lados da meia-quadra ofensiva, a partir de diferentes ações que procuram desequilibrar a defesa.

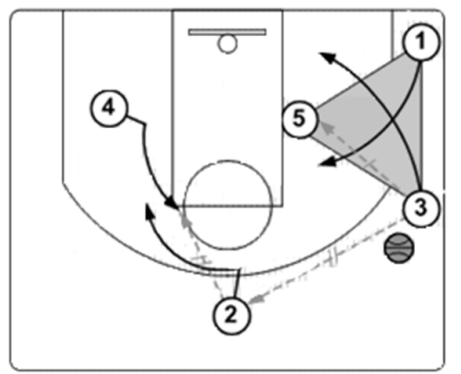

Figura 3: Configuração inicial da ofensiva de triângulos. Onde: setas pretas contínuas indicam deslocamento dos jogadores; setas pontilhadas indicam alternativas de passes, sendo o número de traços transversais nestas setas a indicação da prioridade do passe. Adaptado de WINTER (1962).

Como os triângulos laterais podem ser formados nos dois lados da meia quadra ofensiva, o lado sem um triângulo constituido em um dado instante possui dois jogadores realizando uma movimentação que visa a criação de oportunidade de finalização. Isto obriga a defesa a proteger toda a extensão da meia quadra (WINTER, 1962).

Segundo as especificações estratégicas apresentadas por WINTER (1962), a ofensiva em triângulos tem mais de uma maneira de ser iniciada, todas a partir de um passe que dá início aos deslocamentos dos jogadores da equipe para começar o ataque. Uma das possibilidades de início da movimentação é o corte externo de entrada (outside cut entry), representado na Figura 4. No corte externo de entrada, o jogador 1 passa para 3 e realiza o corte por fora, em direção à região próxima à intersecção da linha de fundo com a linha lateral, denominada zona morta. 3 tem a opção de devolver para 1 quando 
este passa próximo de 3 no seu corte para a zona morta, através de uma ação denominada mão-para-mão. Conforme a denominação, é um passe muito curto, em que o corpo do passador é também usado como anteparo para bloquear a passagem do receptor do passe. Na opção mão-para-mão e penetração (hand off and drive), descrita na Figura $4 a$, quando o defensor de 1 o persegue após ter sofrido um atraso pela obstrução de sua passagem realizada pelo 3, 1 contorna seu companheiro 3 e penetra em direção à cesta. Na opção mão-para-mão e arremesso com salto (handoff and jump), descrita na Figura 4b, quando o defensor de 1 antecipa sua penetração, decsrita na Figura $4 a$, e desloca-se por trás de 3,1 tem a opção de realizar um arremesso pois o espaço foi criado. Na opção mão-para-mão e giro (handoff and roll), descrita na Figura $4 c$, quando os defensores de 1 e 3 fazem uma troca defensiva no instante do mão-paramão, de modo ao defensor do 1 passar a defender o 3 e vice-versa, 1 observa o giro interior de 3 em direção à cesta ou posicionando-se no perímetro do garrafão para atuar, momentaneamente, como pivô para realizar um passe, se as condições forem favoráveis.

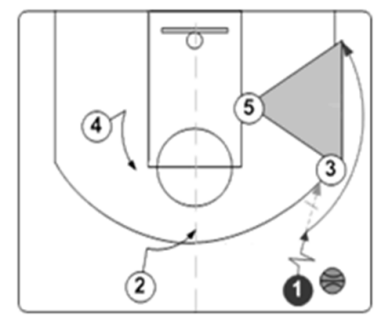

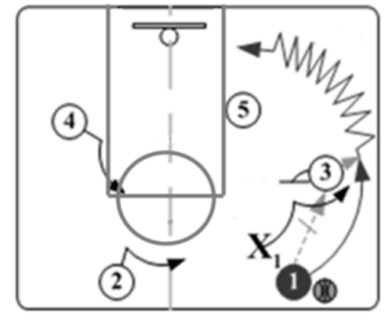

$4 \mathrm{a}$

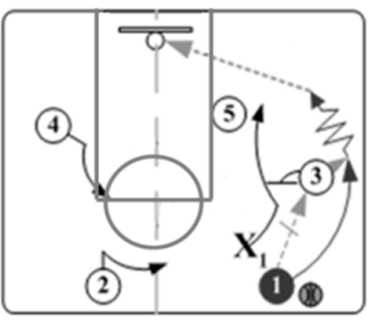

$4 b$

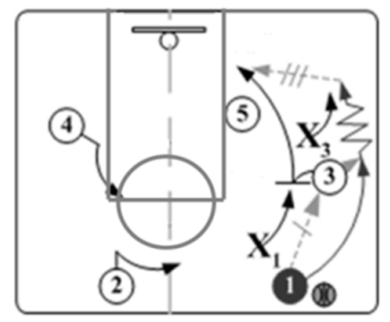

$4 c$

Figura 4: Corte externo de entrada. Figura 4a: Mão-para-mão e penetração; Figura 4b: Mão-para-mão e arremesso; Figura 4c: Mão-para-mão e giro. Onde: setas pretas contínuas indicam deslocamento dos jogadores; setas pontilhadas indicam alternativas de passes, sendo o número de traços transversais nestas setas a indicação da ordem de prioridade do passe; setas pretas com zigue- 
zague indicam deslocamento com drible; seta pontilhada conectada ao aro indica arremesso. Adaptado de WINTER (1962).

Na sequência da movimentação, depois que o primeiro passe é realizado, caso não tenha sido criada uma imediata oportunidade de finalização, os jogadores devem selecionar uma dentre várias alternativas. Uma delas é o corte duplo sobre o pivô a partir da zona morta ( post split off corner pass), descrito na Figura 5. 3 passa para 1 na zona morta e 1 , por sua vez, passa para 5, no perímetro do garrafão. Há uma definição $a$ priori: "quem passa ao pivô, corta primeiro". Então, 1 corta primeiro sobre o pivô e 3 utiliza 1 como um corta-luz em movimento para cortar em direção à cesta e criar uma linha de passe. Se a defesa antecipar a ação do corte duplo e bloquear o movimento de 1, 3 tem a opção de cortar por cima do garrafão e 1 realiza o corte próximo à linha de fundo.

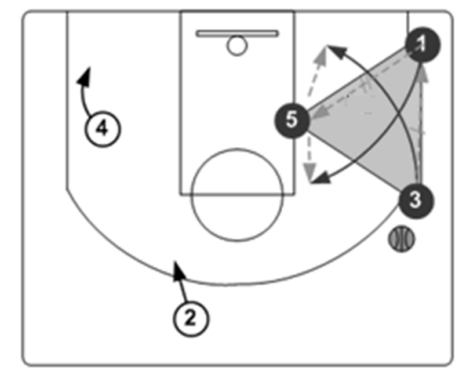

Figura 5: Corte duplo sobre o pivô a partir da zona morta (post split off corner pass). Onde: setas pretas contínuas indicam deslocamento dos jogadores; setas pontilhadas indicam alternativas de passes, sendo o número de traços transversais nestas setas a indicação da ordem de prioridade do passe. Adaptado de WINTER (1962).

No lado oposto à bola da meia quadra ofensiva há especificações para um jogo de dupla, com criação de linhas de passe tanto para realização de inversões de lado no ataque quanto para criação imediata de oportunidades de finalização. Vide 2 e 4 nas Figuras $4 a, b, c$ e 5 .

Todas as especificações de ação para os jogadores, seja na ofensiva em triângulos ou em qualquer outra estratégia ofensiva ou defensiva baseia-se em um 
conjunto amplo, porém finito, de comportamentos realizáveis. As combinações entre esses comportamentos caracterizam as diferenças entre as estratégias de equipes, sendo limitadas pelo regulamento do jogo e condição física, técnica e cognitiva dos jogadores. O mapeamento dos comportamentos possíveis e suas combinações mais eficazes para a formulação da estratégia de uma equipe requer a criação de uma classificação válida deste universo de comportamentos em categorias, reduzindo seu número total através de conjuntos diferenciados entre si por critérios bem definidos.

Uma contribuição nesta direção, no contexto do basquetebol, foi dada por PERSE, KRISTAN, KOVACIC, VUCKOVIC e PERS (2009) em um estudo no qual estes autores modelaram os elementos do jogo necessários à criação de uma metodologia para reconhecimento automático de padrões coletivos de uma equipe. Para tanto, o jogo foi modelado em fases (i.e., ataque, defesa e interrupção) e foram elaboradas classes de ações específicas do basquetebol (e.g., corta-luz, tipos de dribles, tipos de finalização, etc) para a fase do ataque. As classes de ações definidas constituem blocos construtivos de ações mais complexas, empregadas para a descrição dos comportamentos observados em situações reais de jogo. Para avaliar se a ação observada correspondia a uma das classes de padrões definidas anteriormente, a similaridade de ambas foi calculada através da medida de Levenshtein ${ }^{2}$. A efetividade e robustez da abordagem proposta foi demonstrada a partir da identificação automática da movimentação coletiva em diferentes tipos de ataques. Assim, foi evidenciada a maneira pela qual a ação coletiva observada no jogo pode ser decomposta e analisada, sendo os padrões de comportamentos identificados e suas causas e consequências analisadas. A classificação dos comportamentos pode favorecer a interpretação do jogo por favorecer a criação de critérios de análise mais consistentes. Por exemplo, de forma intuitiva, atualmente analisa-se o comportamento de uma equipe nas ações de corta-luz, dentre outras, o que constitui uma delimitação de comportamento do jogo estabelecida pela prática do esporte. Um estudo sobre classificações dos comportamentos pode

\footnotetext{
2 A medida de Levenshtein calcula a distância entre duas sequências baseada em suas métricas. A distância é definida como o número mínimo de interações necessárias para transformar uma sequência na outra, sendo as interações possíveis: inserção, deleção ou substituição de um caracter.
} 
encontrar alternativas com maior valor semântico do que algumas classes estabelecidas, além de, eventualmente, identificar classes menos evidentes ao empirismo das propostas atuais.

A proposta de uma taxionomia pode ser pensada em termos genéricos e aplicada a qualquer ECI. Em uma analogia, assim como em um idioma (e.g., o português), textos são escritos a partir de um conjunto vasto porém finito de palavras, as classes de ações tem função semelhante. Através de suas diversas combinações, distintas estratégias podem ser constituídas. Adicionalmente às combinações possíveis, devem ser acrescidas regras que limitem as combinações àquelas factíveis e eficientes no contexto do jogo.

A elaboração da proposta de classificação apresentada requer a delimitação de classes de equivalência, compostas por um conjunto de comportamentos classificados a partir de elementos comuns entre si, segundo um conjunto de critérios (LAMAS et al., 2011). Estes critérios podem ser mais ou menos restritivos e, consequentemente, uma classe de equivalência pode agrupar mais ou menos comportamentos. LAMAS, DE ROSE JR., SANTANA, ROSTAISER, NEGRETTI e UGRINOWITSCH (2011) propuseram três critérios para constituir classes de equivalência dos comportamentos ofensivos no basquetebol: i) número de jogadores envolvidos, b) gesto técnico utilizado, c) contexto de decisão observado (i.e., tomada de decisão de um único jogador ou coordenação das decisões de dois ou mais jogadores em uma ação coordenada). Assim, torna-se possível realizar a avaliação da tática pela análise da aderência dos comportamentos observados no jogo à estratégia que os orientou, assim como a ocorrência daqueles que distinguiram-se dos especificados pela estratégia para certa situação mas que foram executados para superar uma restrição imposta pelo adversário (ajustes táticos).

Além da necessidade de desenvolvimento de classes de comportamentos metodologicamente fundamentadas, a avaliação da tática a partir das sequências dos comportamentos apresentados na posse de bola, tem limitações metodológicas de validade e reprodutibilidade. Isto ocorre porque a quantidade de dados a serem coletados é grande e há possibilidade de progressiva alteração nos critérios dos observadores em longos períodos de tempo de coleta (CARLING, BLOOMFILED, NELSEN \& REILLY, 2008). Além disso, podem ocorrer sucessivas obstruções da 
visualização de toda a quadra de jogo, pois muitas das análises são feitas através de imagens obtidas pela televisão (BARRIS \& BUTTOM, 2008). Ainda, mesmo em esportes nos quais por grande parte do tempo todos os jogadores aparecem nas imagens (e.g., basquetebol), o tempo requerido para anotar manualmente informação sobre muitos jogadores tem limitado as pesquisas à análise dos comportamentos apenas dos jogadores envolvidos com a bola (BARRIS \& BUTTOM, 2008).

Em decorrência das limitações apresentadas verifica-se interesse da comunidade científica em produzir tecnologias para análise automática ou semi-automática do jogo a partir de diferentes fontes de dados (BARRIS, 2008; BEETZ, KIRCHLECHNER \& LAMES, 2005; PERSE et al., 2009). Atualmente, estes sistemas já são capazes de medir, de maneira semi-automática os deslocamentos dos jogadores no campo de jogo (PERS, BON \& KOVACIC, 2002). De forma complementar, o problema da elaboração de algoritmos que permitam o reconhecimento semântico automatizado dos comportamentos dos jogadores começa ser resolvido (PERSE et al., 2009). Dessa forma, é possível que em algum tempo as análises se tornem mais completas, por contemplarem todos os jogadores no campo de jogo, além de mais precisas pela diminuição de problemas experimentais como o limite da capacidade humana de anotação de observações do jogo. 


\section{PESQUISAS}

3.1 Modelagem da estratégia em esportes coletivos de invasão

A principal contribuição deste capítulo é a apresentação de um modelo formal da estratégia nos ECIs, que dá suporte a futuras pesquisas vinculadas a temáticas como desenho de estratégias de equipes, ambientes computacionais inteligentes para desenho de estratégias, inferência sobre a estratégia de uma equipe através da análise de jogos, e mesmo simulações de comportamentos de equipes. A sub-seção 3.1.1 formaliza a noção de regra de ação e analisa duas aplicações: i) controle de ações estratégicas e táticas no jogo e; ii) coordenação de ações cooperativas entre dois ou mais jogadores. A sub-seção 3.1.2 introduz um modelo matemático da estrutura de representação da estratégia de uma equipe, o framework de estratégias $\left(\mathrm{EST}_{\mathrm{f}}\right)$, e apresenta alguns exemplos de aplicação deste modelo. A sub-seção 3.1.3 introduz uma forma equivalente ao $\mathrm{EST}_{\mathrm{f}}$ que, no entanto, produz representações mais compactas das estratégias de equipes. A subseção 3.1.4 define algumas restrições ao $\mathrm{EST}_{\mathrm{f}}$ que geram uma sub-família de estratégias: o modelo de estratégias de equipes $\left(\mathrm{EST}_{\mathrm{M}}\right)$. Estratégias no $\mathrm{EST}_{\mathrm{M}}$ obedecem ao formalismo do $\mathrm{EST}_{\mathrm{f}}$ e satisfazem algumas condições necessárias para serem efetivamente úteis. A sub-seção 3.1.5 define o conceito de região da bola e apresenta algumas restrições associadas a ela. Finalmente, na sub-seção 3.1.6 as contribuições centrais da pesquisa são retomadas, suas relações com outros resultados conhecidos são discutidas, além de serem feitas indicações de desenvolvimentos teóricos futuros e aplicações das descobertas realizadas no esporte e em áreas correlatas.

\subsubsection{Controle multi-nível de ação dos jogadores}

A noção de regra de ação, proposta de maneira qualitativa por alguns autores (GREHAIGNE \& GODBOUT, 1995; MCPHERSON, 1999a), será formalizada, sendo sua importância para a representação do controle das ações dos jogadores demonstrada na sequência. Uma regra de ação é definida como uma declaração condicional com a

seguinte estrutura "se <condição>, então <ação>", na qual, a condição é uma 
interpretação lógica da percepção do contexto pelo jogador e a ação é a especificação de uma ação executada com o objetivo de modificar o contexto. Por exemplo, no ataque do basquetebol, "se <meu companheiro de equipe realiza um arremesso >, então <eu devo posicionar-me para o rebote>"; em uma ajuda defensiva no futebol, "se <meu companheiro de equipe é superado pelo atacante>, então <eu devo recuperar sua posição defensiva >". Dessa forma, a regra formaliza a maneira pela qual a especificação estratégica exerce o controle lógico da dinâmica dos jogadores, pois determina a escolha da ação de um jogador, em um dado contexto.

Cada ECI é praticado através de um conjunto finito de habilidades motoras especializadas, compatíveis com a dinâmica do esporte em questão, que podem ser compreendidas em dois níveis de detalhamento de suas estruturas. Estas habilidades motoras podem ser descritas tanto por suas macro-estruturas, por exemplo uma bandeja no basquetebol, quanto pelas habilidades motoras básicas que as compõem, por exemplo na bandeja, a corrida, o salto e o arremesso da bola. Há dois tipos de regras de ação: regras de alto e baixo nível. Uma regra de alto nível controla uma ação que representa uma habilidade esportiva ${ }^{3}$, cuja execução é controlada por uma sequência de regras de baixo nível. Cada regra de baixo nível controla a execução de uma ação que representa uma habilidade de movimento básico ${ }^{4}$, decomposta a partir da habilidade esportiva. Portanto, uma regra de alto nível controla uma sequência de regras de baixo nível.

O conceito de regra de ação não é útil apenas para representar a estratégia mas também para modelar o sistema de controle de um jogador durante o jogo. Na sequência, serão discutidos os conceitos de regra de ação estratégica e regra de ação tática.

Os comportamentos observados no jogo são delimitados pela orientação estratégica dada aos jogadores e pelas alternativas táticas para situações não

\footnotetext{
${ }^{3}$ Uma habilidade esportiva é entendida como uma habilidade motora aprendida e empregada no contexto de um esporte específico. Por exemplo, a bandeja do basquetebol.

${ }^{4}$ Uma habilidade de movimento básico é entendida como uma habilidade constitutiva de uma habilidade esportiva. Por exemplo, para a habilidade esportiva "bandeja", são habilidades de movimentos básicos: i) correr; ii) saltar; iii) lançar a bola.
} 
contempladas pela estratégia. Tanto as decisões estratégicas quanto as táticas são formalizadas por regras de ação. Regras de ação estratégicas fazem parte do conjunto de especificações para um jogador com origem no planejamento da equipe, enquanto as regras táticas advém do acervo cultural do esporte adquirido pelo jogador com o tempo de prática. Por exemplo, pode haver uma situação na qual o planejado seja a realização de um passe pelo jogador com bola para atingir uma determinada região do campo de jogo. Porém, frente à uma impossibilidade de realizar o passe em decorrência da oposição, outra alternativa, tal como a condução da bola, pode ser tentada para atingir o mesmo objetivo.

As regras de ação estratégicas e táticas diferenciam-se em regras de alto e baixo nível. No alto nível, uma regra de ação define a habilidade esportiva a ser executada. Em circunstâncias nas quais não há uma regra de ação estratégica adequada disponível, uma regra de ação tática é aplicada. No baixo nível, é aplicada uma lista de regras de ação que controlam a execução das habilidades de movimentos básicos derivadas da habilidade esportiva selecionada no alto nível. No caso de uma das habilidades de movimentos básicos não poder ser executada, um ajuste é realizado pela aplicação de uma outra regra de ação de baixo nível.

Para ilustrar os conceitos descritos acima, alguns exemplos serão discutidos. No basquetebol, uma regra de ação estratégica de alto nível, planejada para o jogador com bola realizar uma finalização através de uma bandeja pode especificar que: se <eu recebo um corta-luz na lateral, próximo à linha de três pontos > então <eu devo penetrar à cesta para realizar uma bandeja>. Entretanto, o contexto do jogo pode se modificar. Por exemplo, pode acontecer do defensor do jogador com bola ser capaz de interromper a penetração à cesta especificada pela regra de ação. Se isso ocorre é necessário haver alguma alternativa de ação. A alternativa pode também ser previamente planejada (i.e., outra regra de ação estratégica de alto nível) ou depender da sagacidade do jogador para solucionar a situação, levando em consideração sua experiência no esporte (i.e., uma regra de ação tática de alto nível). Assim, a regra de ação subsequente do jogador com bola pode especificar que: se <meu defensor interrompe minha penetração à cesta>, então <eu devo brecar e dar um passo atrás para distanciar-me>. Esta poderia ser uma típica regra de ação tática, pois a ação especificada não é coordenada com a ação de outros jogadores. Por outro lado, a regra de ação poderia ser: se <meu defensor 
interrompe minha penetração à cesta>, então <eu devo brecar, dar um passo atrás e passar ao pivô no garrafão>. A integração da própria ação com a de outro jogador pode denotar um plano e, nesse sentido, o uso de uma regra de ação estratégica. Ocorre um problema quando o jogador não possui nenhuma dessas duas fontes de alternativas de regras de ação. Nestes casos, ele não é capaz de realizar uma ação com consequências positivas para a atuação coletiva de sua equipe. Em algumas situações, por exemplo sob estresse psicológico, o jogador pode não atuar de acordo com uma regra de ação estratégica de alto nível existente e apropriada. As regras de ação empregadas nessas situações são denominadas transgressões e significa que uma regra de ação com baixa prioridade é aplicada ao invés de uma regra com alta prioridade, violando o planejamento coletivo.

A seguir é apresentada uma consequência lógica do conceito de regra de ação, a representação das interações cooperativas entre os jogadores da equipe através da concatenação de suas regras de ação.

A interação cooperativa entre jogadores de uma equipe pode ser modelada representando o controle da ação de cada jogador por uma lista de regras de ação. Se R1 e R2 são duas regras de ação tais que a condição de R2 é a consequência ${ }^{5}$ de R1, então R1 é concatenada com R2. Se R2 é também concatenada com R1, então R1 e R2 são reciprocamente concatenadas. Note que, no primeiro caso, R1 e R2 podem ser regras de ação do mesmo jogador ou de dois jogadores diferentes, mas no segundo caso devem ser de dois jogadores diferentes. Se R1 é concatenada com R2 e R1 e R2 são regras de ação dos jogadores p1 e p2, respectivamente, então p2 é dependente de p1. Se R1 e R2 são reciprocamente concatenados, então p1 e p2 são reciprocamente dependentes. A dependência entre os jogadores é aplicada para definer o conceito de unidade estratégica, que formaliza a noção de interações cooperativas entre jogadores da equipe.

Uma unidade estratégica (UEST) é recursivamente definida pelas seguintes declarações: i) um conjunto unitário composto por um jogador é uma UEST; ii) se dois sub-conjuntos $X$ e $Y$ de jogadores são UESTs e cada jogador de $X$ tem uma dependência

5 A consequência de R1 é a função lógica verdadeira se e somente se houver equivalência entre a interpretação semântica da modificação do ambiente do confronto produzida pela ação controlada por R1 e a especificação da condição de R2. 
recíproca com cada jogador de $Y$, então o sub-conjunto $X$ U $Y$ é uma UEST. Por exemplo, como, por definição, $\{1\}$ e $\{2\}$ são UESTs, se exisitir uma dependência recíproca entre 1 e 2 , então $\{1,2\}$ é uma UEST. A principal propriedade de uma UEST, composta por mais de um jogador, é que todas as ações do seu conjunto de jogadores são dependentes.

Uma UEST $Y$ é dependente de uma UEST $X$ se existirem dois jogadores $x$ e $y$, respectivamente, de $X$ e $Y$, tais que $y$ seja dependente de $x$. Assim, a formação dos grupos é consequência das regras de ação aplicadas.

A Figura $6 a$ ilustra as especificações das ações dos jogadores de uma equipe de basquetebol em uma dada circunstância de jogo. De forma complementar, o diagrama da quadra da Figura $6 b$, denominado mapa de interações cooperativas, representa as dependências entre jogadores e grupos de jogadores para as especificações de ações da Figura $6 a$. Na Figura $6 b$, há três UESTs: $\{1,3,5\},\{2\}$ e $\{4\}$. Na UEST $\{1,3,5\}$, os jogadores têm dependência recíproca, representada pelas setas bi-direcionais que os conectam. As UESTs $\{2\}$ e $\{4\}$ são dependentes da UEST $\{1,3,5\}$, uma vez que 2 e 4 são dependentes de 1,3 e 5 , o que é representado por setas unidirecionais.

a)

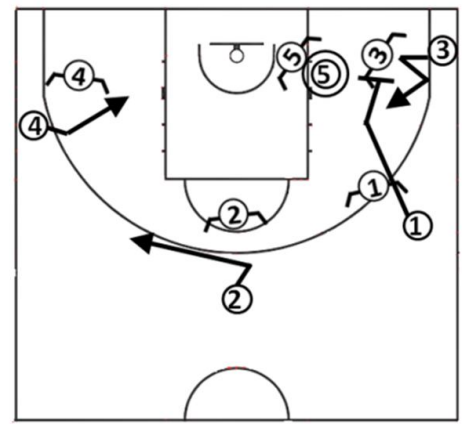

b)

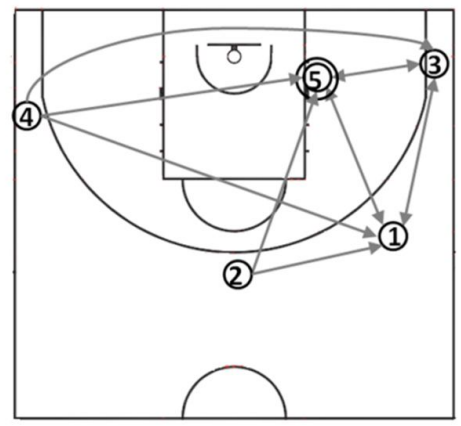

Figura 6a: Descrição das ações dos jogadores de uma equipe. Figura 6b: descrição das dependências entre jogadores e grupos de jogadores de uma equipe.

Na sequência, é formalizado um segmento de uma jogada apresentada na Figura $6 a-b$, por um conjunto de regras de ação.

Jogador 1: se <5 tem a bola e 3 desloca-se para receber um corta-luz feito por mim>, então <eu realizo um corta-luz para $3>$; 
Jogador 3: se $<5$ tem a bola e 1 realiza um corta-luz para mim>, então <eu me desloco para receber o corta-luz de 1>;

Jogador 5: se <eu tenho a bola e 1 realiza um corta-luz para 3 e 3 recebe um corta-luz de 1 , então <eu mantenho a bola comigo>;

Jogador 4: se <5 tem a bola e 1,3 deslocam-se para um corta-luz>, então <eu me desloco para a região da zona morta dentro do perímetro da linha dos três pontos>.

Jogador 2: se $<5$ tem a bola e 1,3 deslocam-se para um corta-luz>, então <eu me desloco para o lado oposto à bola $>$.

Note que as especificações dos diagramas das quadras apresentadas nas Figuras $6 a-b$ são equivalentes às especificações oferecidas pelas listas de regras de ação. $\mathrm{Na}$ Figura $6 a$, as ações apresentadas são a consequência da aplicação da regra de ação de cada jogador (e.g., o corta-luz). Na Figura 6b, as UESTs apresentadas são especificadas pela concatenação das regras de ação dos jogadores das UESTs, de maneira recíproca (e.g., jogadores 1, 3 e 5) ou unidirecional (e.g., jogador 4 em relação aos jogadores 1, 3 e 5). As relações entre UESTs são especificadas pela concatenação das regras de ação dos jogadores das distintas UESTs (e.g., 2 e 5 , 4 e 3).

Em um dado instante do jogo, várias UESTs estão atuando, com distinto número de jogadores em cada uma delas. A decomposição dos jogadores da equipe em UESTs possui uma dentre as seguintes estruturas: i) uma única UEST constituída por todos os jogadores da equipe, ii) múltiplas combinações de número de jogadores em cada UEST. Durante o jogo, o sistema lógico de controle de uma equipe permite a realização de mudanças dinâmicas na decomposição dos jogadores da equipe, desfazendo e criando novas UESTs em subsequentes intervalos de tempo. Neste sistema dinâmico complexo, os momentos de reorganização das UESTs são cruciais, uma vez que envolvem a sincronização de diversos jogadores.

A sincronização das regras de ação de um grupo de jogadores é realizada pela concatenação uni ou bidirecional entre cada dois jogadores do grupo. Duas regras de ação concatenadas e portanto dependentes, seja de forma unidirecional ou recíproca, determinarão a execução de duas ações consecutivas. Para que este par de ações seja eficiente, é necessário que o jogador dependente execute sua regra no momento especificado após o início da execução do primeiro jogador, sendo que no máximo a execução do segundo deverá ocorrer imediatamente após o término da execução do 
primeiro. Esta concatenação temporal precisa de duas ações, controlada por duas regras de ação, é chamada coordenação. Se dois jogadores são dependnetes do mesmo jogador e devem executar suas ações ao mesmo tempo, eles devem ter uma coordenação simultânea disparada pela ação do primeiro jogador, o que é denominado sincronização. O controle dinâmico de uma equipe, que possui os conceitos centrais de coordenação e sincronização, é o controle motor da execução das habilidades motoras dos seus jogadores (OGATA, 1986).

O controle lógico e dinâmico de uma equipe é denominado orquestração, inspirado no fato do controle de uma orquestra (que parece mais intuitivo) poder ser representado por um modelo semelhante. Neste caso, a ação que dispara as demais é sempre realizada pelo regente, que utiliza uma linguagem corporal particular e bem conhecida pelos músicos. Neste caso, um instrumento pode produzir a melodia conjuntamente com outros, em uma ação sincronizada ou suceder a outro na continuidade da melodia em uma ação coordenada. Seja no contexto musical ou esportivo, regras de ação especificam a ação a ser realizada por cada indivíduo e, de acordo com o contexto, estes cooperam com dependência recíproca ou simples, constituindo as UESTs para realizar uma movimentação no campo de jogo ou um naipe (e.g., subconjunto de cordas, percussão e sopros) para realizar parte de um movimento em um concerto.

\subsubsection{Estrutura de representação da estratégia da equipe}

Nesta seção será apresentado um modelo formal da elaboração de sequências de objetivos estratégicos e definição das correspondentes sequências de ações dos jogadores em suas respectivas UESTs. Este modelo formaliza a noção de estratégia, concebida pela comissão técnica para orientar os jogadores durante um jogo. O jogo ocorre com ambas equipes tentando seguir suas especificações estratégicas, que são realizadas até serem completadas (e.g., uma finalização à meta) ou interrompidas (e.g., uma violação cometida). Uma vez terminada a ação, as orientações dos jogadores são atualizadas através da definição de um novo objetivo estratégico e de procedimentos correspondentes, que redefinem as UESTs da equipe. 
O modelo formal da estratégia em um ECI define o fenômeno como uma família particular de sistemas dinâmicos discretos estocásticos, denominada framework do modelo de estratégia da equipe $\left(\mathrm{EST}_{\mathrm{f}}\right)$. $\mathrm{O}$ sistema dinâmico modelado é discreto porque a estratégia é representada por um conjunto de especificações de ações a serem executadas pelos jogadores, descritas em pontos específicos no tempo. Além disso, o sistema é estocástico porque há diversos estados a partir dos quais pode haver mais de uma possível especificação subsequente, com chances diferentes de escolha.

A formalização dos momentos nos quais ocorrem as especificações estratégicas do $\mathrm{EST}_{\mathrm{f}}$ se dá pela definição do conceito de estado. Um estado é composto por duas estruturas principais: i) estado de movimento; e ii) transformação. A formalização destas estruturas será detalhada na sequência.

Um estado de movimento é composto por cinco elementos. Primeiro, são especificados todos os jogadores da própria equipe e da equipe adversária no campo de jogo, que possuam relevância semântica ${ }^{6}$ para o estado. Quando os adversários especificados não são a equipe completa, isto significa que a semântica do estado de movimento não depende dos jogadores não-especificados. Segundo, é definida a região para cada jogador no campo de jogo. Cada região representa uma classe de equivalência de posicionamento, na qual qualquer ponto dentro dessa região ocupada pelo jogador tem o mesmo significado semântico. Assim, independente do ponto em que o jogador se encontre dentro da sua região correspondente, o estado caracterizado será o mesmo. Além disso, os deslocamentos dos jogadores podem implicar distâncias curtas ou até mesmo contato físico entre dois ou mais jogadores e, como consequência, as regiões podem ter intersecção com áreas de ocupação de espaço compartilhadas (e.g., posicionamento para um rebote depois de um arremesso, no basquetebol). Terceiro, a dinâmica dos jogadores (i.e., posição tri-dimensional instantânea, velocidade e aceleração em uma dada região). Quarto, o jogador em posse da bola, pois se a equipe tem a posse da bola ou não implica diferentes tipos de estratégias. Quinto, a dinâmica da bola, definida por sua posição instantânea, velocidade e aceleração. A dinâmica da bola

\footnotetext{
${ }^{6}$ No contexto deste trabalho, o termo semântica denota o significado estratégico ou tático do elemento do formalismo que estiver sendo discutido ou explicado.
} 
é determinada por um chute, arremesso, passe ou pelo movimento do jogador que a controla. Note que dois estados de movimento são diferentes quando ao menos um de seus elementos constitutivos (i.e., i- jogadores especificados; ii- região dos jogadores; iii- suas dinâmicas; iv- posse da bola; v- dinâmica da bola) diferir.

As Figuras $7 a$ e $7 c$ apresentam estados de movimento típicos. Na $7 a$ e $7 c$, o segundo círculo em torno do jogador 5 representa a bola. A elipse externa a todos os jogadores em $7 a$ e $7 c$ indica a região de posicionamento dos jogadores (i.e., classe de equivalência de posicionamento). Jogadores defensivos são representados por círculos com traços pretos adjacentes, simbolizando seus braços. Esta notação tem o propósito de indicar a direção da rotação corporal dos jogadores de defesa, caracterizado como um importante elemento estratégico, além de explicitar eventuais linhas de passe obstruídas. No ataque, assume-se que os jogadores estão sempre voltados para a bola ou na direção adequada para realização das ações.

A transformação especifica as tarefas dos jogadores da equipe (i.e., trajetória no campo de jogo e respectivas habilidades motoras realizadas) e suas dinâmicas. Há transformações nas quais nenhum jogador se desloca mas ocorre uma modificação na semântica da equipe. Por exemplo, se a bola é passada, há uma mudança na ação de dois jogadores e, possivelmente, em suas dinâmicas (Figura 7bl). Ainda, a transformação especifica as interações cooperativas entre alguns dos jogadores, que constituem as UESTs da transformação. A coordenação das UESTs define a orquestração da equipe, cujas especificações são modificadas na transformação seguinte. As UESTs são especificadas por diagramas de setas, com notação idêntica à da Figura 6 (seção anterior). A especificação completa de uma transformação é ilustrada nas Figuras $7 b 1$ e $7 b 2$. Esta especificação é representada de forma equivalente por uma lista de regras de ação dos jogadores.

Um estado é uma ponte que recebe como entrada um estado de movimento, o estado de movimento-entrada, modifica essa entrada pela transformação, que reposiciona e atualiza a dinâmica dos jogadores da equipe, definindo a constituição do estado de movimento subsequente. No estado de movimento-saída são definidas as regiões dos jogadores, suas dinâmicas e a posse e dinâmica da bola. A dinâmica dos jogadores é definida pela dinâmica final da transformação. Além disso, suas regiões são planejadas de acordo com a posição final da transformação. As regiões e dinâmicas dos 
jogadores adversários são planejadas arbitrariamente para o estado de movimento-saída. A especificação dos adversários no estado de movimento-saída é opcional e depende da relevância semântica dos jogadores para o estado subsequente. Para uma estratégia ofensiva, se no planejamento os defensores forem considerados justapostos a seus respectivos atacantes, aqueles não precisam ser representados pois seu posicionamento esperado é justaposto. Entretanto, se houver planejamento para atuar contra algum posicionamento defensivo menos convencional, os defensores que caracterizarem o posicionamento alternativo devem ser representados. Para a defesa se aplica a mesma regra de representação dos atacantes adversários.

A Figura 7 apresenta o processo de transformação de um estado de movimentoentrada em um novo estado de movimento-saída através de uma transformação e especificações complementares (i.e., regiões e dinâmica dos jogadores da equipe e dos adversários com relevância semântica).

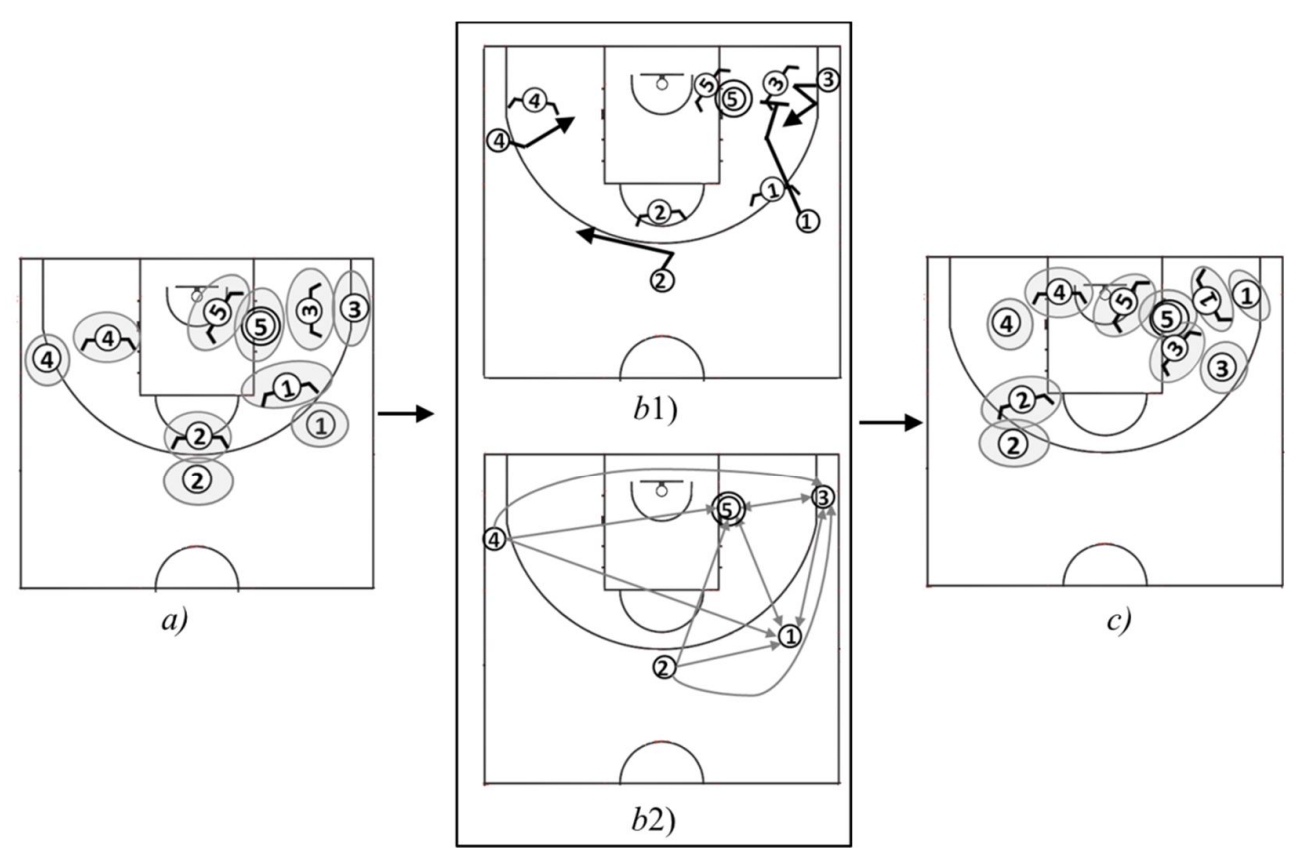

b)

Figura 7: Decomposição de um estado em seus elementos, ilustrado por diagramas convencionais de quadras de basquetebol. Onde: a) estado de movimento- 
entrada; b) transformação: b1) deslocamentos; b2) interações cooperativas; c) estado de movimento-saída.

De acordo com a definição de estado, deve haver um único mapa de interações cooperativas para cada transformação, pois uma única regra de ação pode ser aplicada por cada jogador em um estado. Com isso, durante uma transformação, os tipos de dependências entre os jogadores não devem ser alterados. Assim, se uma movimentação planejada requer uma concatenação complexa entre os jogadores, sua especificação estratégica deve ser decrita ao longo de uma sequência de estados, na qual cada estado contém apenas um mapa de interações cooperativas. Dessa forma, uma movimentação é descrita de acordo com o formalismo utilizado na definição de um único estado.

Para se desenhar uma sequência consistente de estados, é necessário que dois estados subsequentes sejam compatíveis, ou seja, o estado de movimento-saída do primeiro seja idêntico ao estado de movimento-entrada do segundo. Uma jogada é modelada por uma sequência tal que cada par de estados subsequentes é compatível. Duas ou mais jogadas podem ser iniciadas a partir de um único estado. Nestes casos, a decisão sobre a escolha de um dado estado subsequente é planejada estrategicamente para ser realizada por um dos jogadores da equipe. O jogador escolhido pode utilizar algum meta-dado (i.e., informação do jogo, tal como tempo restante, diferença no placar entre as equipes, capacidades técnicas e táticas dos jogadores, etc.) para tomar uma decisão quanto à regra de ação, de uma lista de regras de ação especificadas, que será aplicada. A chance de escolher qualquer regra de ação da lista é dada pela distribuição de probabilidades da seleção do próximo estado condicionada ao estado presente. Esta distribuição é parametrizada por meta-dados que são construídos a partir de dados de jogos prévios da equipe (i.e., successos e fracassos nas utilizações prévias da estratégia).

A decisão tomada pelo jogador especificado determina o avanço da equipe para o próximo estado. Então, no estado seguinte, o jogador que tomou a decisão começa a executar a habilidade esportiva especificada pela regra de ação selecionada na lista. Este é o evento de disparo que informa os demais jogadores sobre a jogada que deverá ser executada. Por exemplo, considere-se a seguinte especificação dinâmica: o estado de movimento-entrada apresentado na Figura $7 a$ tem um estado prévio, em que no estado de movimento-saída os jogadores estão na mesma posição da Figura $7 a$ e 1 é o jogador 
com a bola. 1 pode passar para 3 ou 5 e decide passar para 5 , o que define a jogada subsequente. A recepção do passe pelo 5, consumada no estado de movimento-entrada indicado na Figura 7a, é o evento de disparo para as seguintes ações: 1 realiza um bloqueio para 3, enquato 4 e 2 deslocam-se para regiões pré-definidas da quadra, conforme indicado na Figura $7 b 1$.

Uma estratégia é composta por um conjunto finito de estados e conexões entre pares de estados compatíveis e pode ser representada por um grafo ${ }^{7}$. Cada nó do grafo de uma estratégia é associado a um estado e os arcos do grafo conectam nós associados a estados adjacentes. Um estado armazena a semântica de um fragmento de uma jogada e o grafo representa as conexões entre fragmentos para definir uma jogada completa. $\mathrm{Na}$ sequência, a Figura $8 a$ apresenta um grafo com uma sequência de estados e a Figura $8 b$ detalha as especificações de cada um desses estados.

${ }^{7}$ Um grafo é definido pelo par ordenado $G=(N, A)$ que contempla um conjunto $N$ de nós e um conjunto $A, A$ Í $N \times N$, de arcos. 
a)
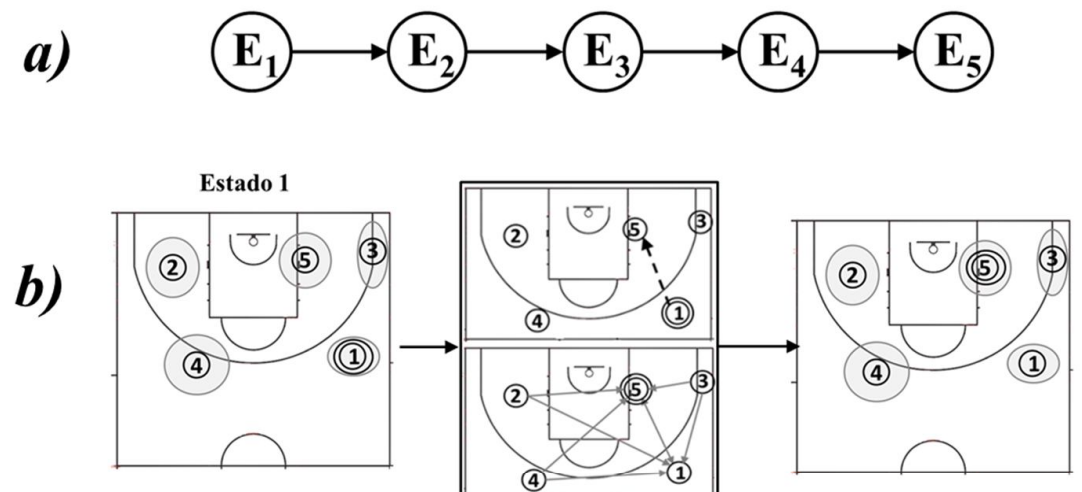

Estado 2
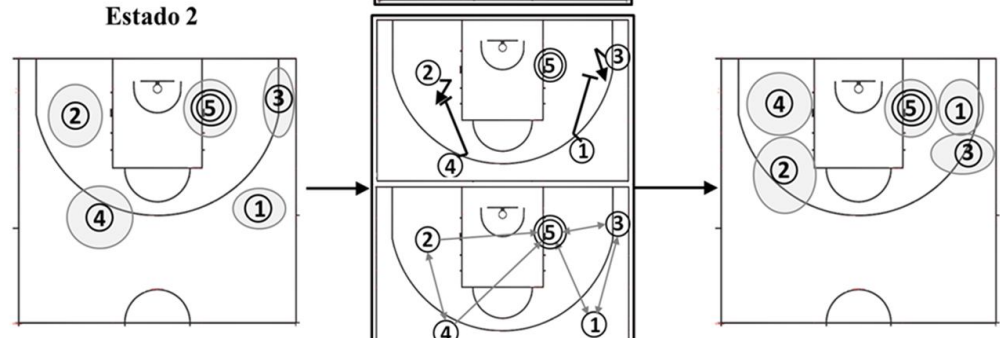

Estado 3
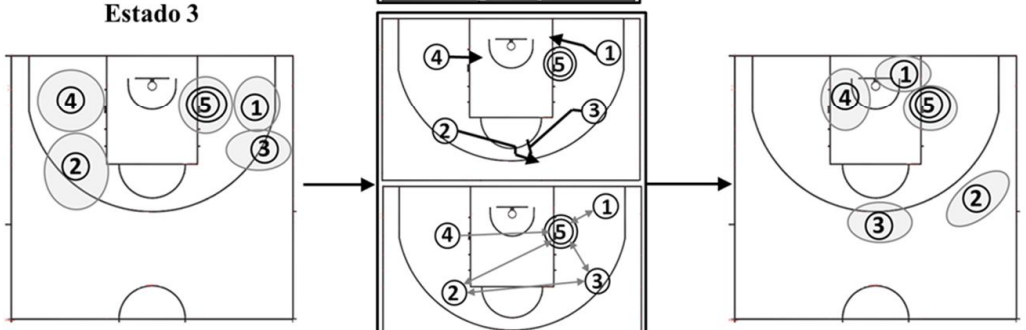

Estado 4

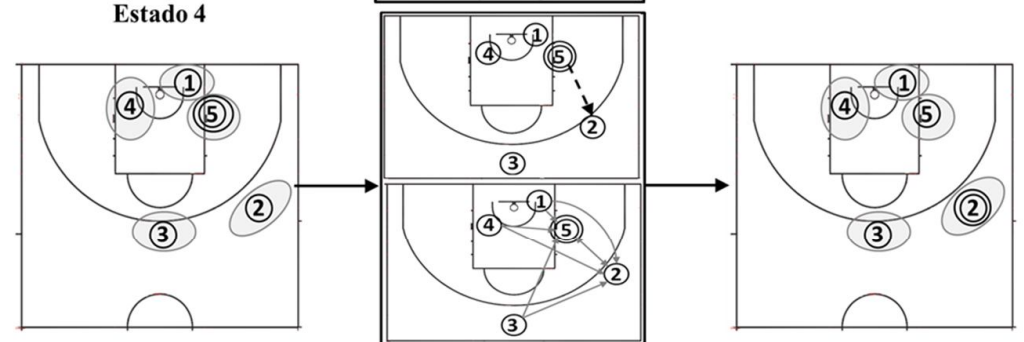

Estado 5
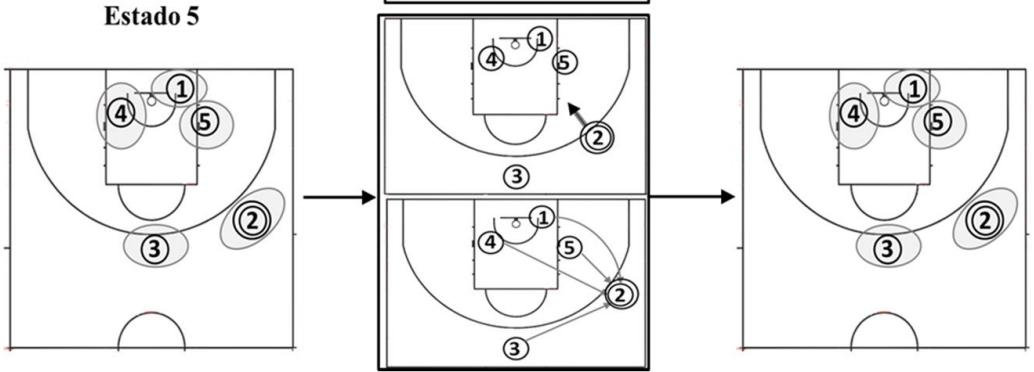

Figura 8a: Grafo com estados (En) e conexões entre estados indicadas pelas setas pretas; 8b: Sequência de estados que descreve uma movimentação de uma 
estratégia no basquetebol. Cada estado é representado por seus componentes: estado de movimento-entrada, transformação (diagramas de deslocamentos e interações cooperativas) e estado de movimento-saída.

Toda estratégia de um $\mathrm{EST}_{\mathrm{f}}$ é modelada como um sistema dinâmico discreto Markoviano (i.e., a escolha, ou de forma equivalente, a distribuição condicional, do próximo estado depende somente do estado presente). Como decorrência de suas propriedades, uma estratégia do $\mathrm{EST}_{\mathrm{f}}$ pode ser representada por um grafo, sendo este uma alternativa útil para a comissão técnica identificar a estrutura geral da estratégia planejada e interpretar cada uma das sequências de estados à luz da estratégia completa. Para ilustrar esse conceito, na sequência, uma variação da conhecida estratégia ofensiva no basquetebol, denominada ofensiva em triângulos (WINTER, 1962), será apresentada por um grafo (Figura 9). Uma região particular do grafo delimitada com uma linha pontilhada indica dois caminhos distintos (destacada abaixo do grafo), cujos conteúdos serão especificados na sequência. No início da Figura 9 pode ser observado que os dois caminhos têm um início comum no primeiro nó (i.e., que contém a especificação do estado $\left.E_{1}\right)$. No segundo nó $\left(E_{2}\right)$, dentre os sete caminhos possíveis, serão destacados os dois que terminam, respectivamente em $\mathrm{E}_{5}$ e $\mathrm{E}_{8}$. 


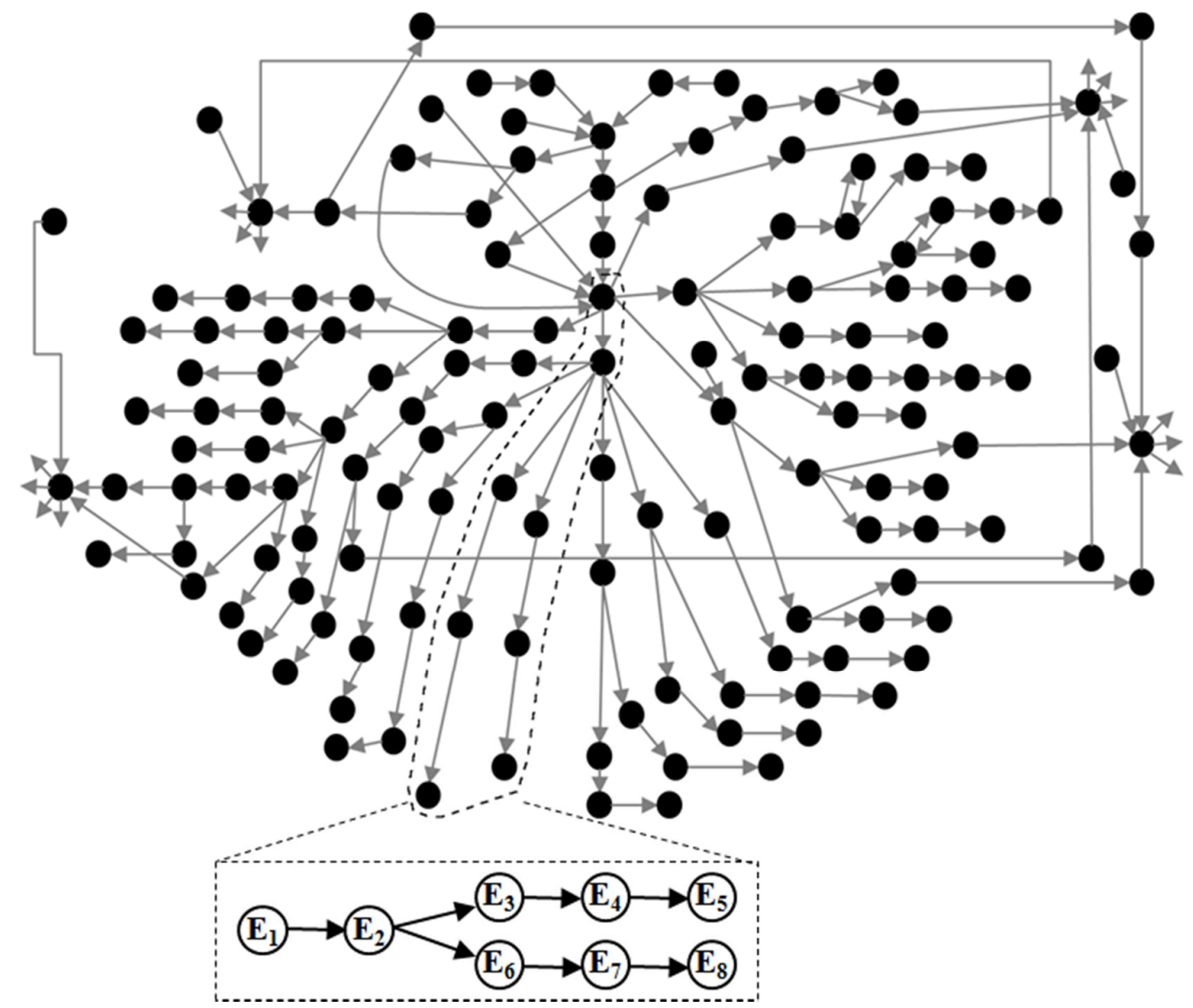

Figura 9: Uma variação da estratégia ofensiva do basquetebol, a ofensiva em Triângulo, representada por um grafo construído a partir do ESTf, no qual: En designa o nome de um estado em um caminho do grafo.

As sequências destacadas na região do grafo selecionada na Figura 9 são especificadas na Figura 10. Para este propósito, foi utilizada uma notação condensada para o estado. Cada sequência de dois diagramas de quadras de basquetebol corresponde a um estado no qual o estado de movimento-entrada e a transformação estão no primeiro diagrama e o estado de movimento-saída é o estado de movimento-entrada do diagrama subsequente.

No primeiro diagrama de quadra da Figura 10 (Q1) é planejado que o jogador 3 deva fazer um passe (seta negra pontilhada no diagrama) para o jogador 5 (números dos jogadores em itálico. Um círculo extra ao redor do número de cada jogador indica a posse da bola). O passe interior para 5 é o evento que dispara o deslocamento de 1,2,3 
e4 (seta negra contínua) representado em Q2. Em Q2, 1 e 3 realizam cortes subsequentes sobre 5 enquanto 2 desloca-se para o lado oposto à bola e 4 aproxima-se do garrafão. Após, em Q3, 5 permanece com a bola, 1 realiza bloqueio para 4, 4 desmarca-se através do bloqueio de 1,2 desloca-se para criação de linha de passe do lado da bola e 3 finaliza seu corte no lado oposto do garrafão. Em Q4, 1 faz bloqueio para 3, 4 e 2 criam linhas de passe e 5 passa a 3. Em Q5, 3 finaliza à cesta e os demais preparam-se para a disputa da posse de bola. De maneira alternativa, em Q6 5 permanece com a bola, 1 realiza bloqueio para 4, 4 desmarca-se através do bloqueio de 1, 2 desloca-se para criação de linha de passe do lado da bola e 3 finaliza seu corte no lado oposto do da quadra, fora da linha dos três pontos, craindo mais espaço ao jogo próximo ao garrafão. Em Q7, 1 prossegue na direção da linha dos três pontos após a realização do bloqueio no estado anterior e 5 realiza o passe para 4. Em Q8, 4 finaliza à cesta e os demais preparam-se para a disputa da bola.

Nos diagramas da Figura 10, os jogadores defensivos não são representados. De acordo com o formalismo da linguagem para especificação de estratégias de equipes, há duas circunstâncias nas quais os diagramas podem ser simplificados com a omissão de alguns jogadores, sem perda de compreensão. Primeira, se o estrategista considera que os adversários se encontram justapostos aos jogadores de sua equipe no estado desenhado, sendo desnecessária a representação. Segunda, se ele assume que seus jogadores têm vantagem inquestionável sobre os adversários e devem ser capazes de reconhecer a melhor alternativa às suas ações futuras, limitando o suporte estratégico a circunstâncias de decisões não-triviais dos jogadores. 


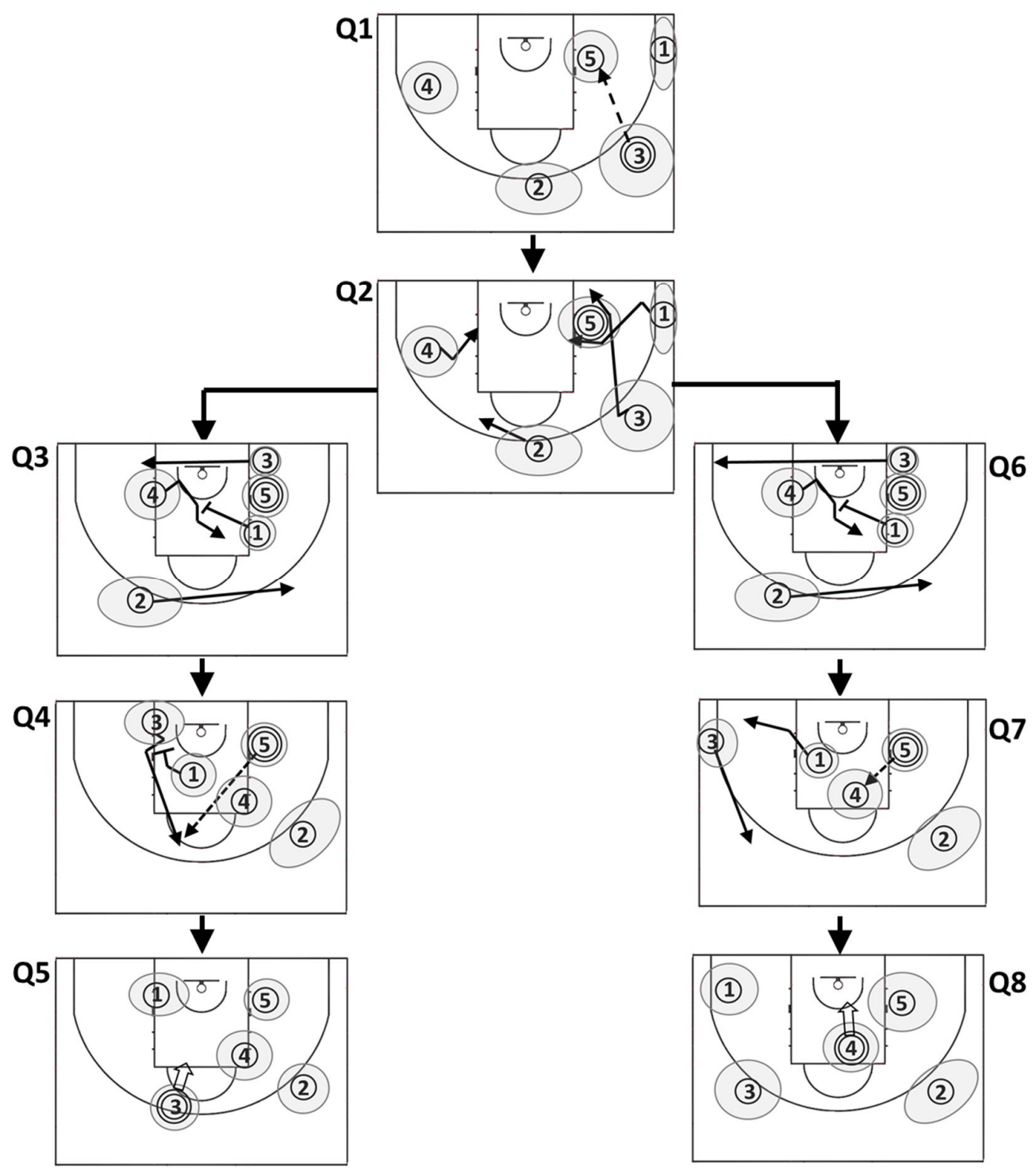

Figura 10: Representação de duas sequências de estados de uma variação da estratégia ofensiva de basquetebol denominada Ofensiva em triângulos, na qual: círculos com números no interior: jogadores; setas pretas: deslocamentos; círculos cinzas: regiões de cada jogador; segundo círculo externo: jogador da bola. 


\subsubsection{Representação paramétrica da estratégia da equipe}

Nesta seção será apresentado um modelo para a criação de uma estratégia com reduzido número de estados, cuja representação pelo grafo preserva a estrutura principal do grafo original. A redistribuição de tarefas entre os jogadores que ocorre na transformação de cada estado pode produzir grande diversidade de variantes da mesma estratégia aumentando consideravelmente o número de estados de um grafo estratégico. Baseado no formalismo apresentado na seção anterior, dois estados cujas especificações sejam as mesmas, exceto pelos jogadores especificados para realizar cada uma das tarefas, são considerados estados diferentes. Na prática dos ECIs esse efeito multiplicador é minimizado pois as tarefas especificadas em vários estados podem ser executadas por parte dos jogadores da equipe ou, em certos casos, até mesmo por todos eles. Com isso, há diversos estados equivalentes, apenas com a modificação do jogador que executa cada tarefa. Para formalizar esta noção de equivalência entre jogadores incumbidos de uma mesma tarefa é introduzida a representação paramétrica para um estado. Dessa forma, os elementos constitutivos do estado (i.e., região dos jogadores, dinâmica dos jogadores e da bola) são considerados constantes,. Se um desses elementos constitutivos é alterado, um novo estado é caracterizado. Por outro lado, se ocorre uma permuta dos jogadores designados para cada tarefa, o estado é conservado, pois o jogador é o seu único parâmetro. A classe de equivalência de estados quase idênticos, exceto pela redistribuição dos jogadores da equipe no conjunto de tarefas especificadas é representada como sendo o mesmo estado, o estado paramétrico.

Em um ECI, no qual a formação da equipe no campo de jogo é composta por $n$ jogadores, os parâmetros do estado (i.e., rótulos de identificação dos jogadores com seus nomes ou números do uniforme) são representados por um vetor $\bar{p}$ de $n$ posições. Nesta representação, um índice $i$ (i.e., $1 \leq i \leq n$ ) de $\bar{p}$ é uma tarefa e $\bar{p}[i]$ representa o elemento de identificação de um jogador. De forma análoga à descrição da região dos jogadores em um estado, se a região de um jogador é modificada, o rótulo de identificação do jogador é carregado para a nova região. A representação interna dos parâmetros de um estado é independente da representação de outros estados. Para dois

estados conectáveis entre si, é necessário mapear corretamente as estruturas correspondentes. Em uma transição do estado $\mathrm{E}_{1}\left(\bar{p}_{\mathrm{E} 1}\right)$ para $\mathrm{E}_{2}\left(\bar{p}_{\mathrm{E} 2}\right)$, o mapeamento dos 
parâmetros é dado pela seguinte regra: se as regiões de $\bar{p}_{\mathrm{E} 1}[i]$ e $\bar{p}_{\mathrm{E} 2}[j]$ são as mesmas, então $\bar{p}_{\mathrm{E} 2}[j] \leftarrow \bar{p}_{\mathrm{E} 1}[i]$, ou seja, $j$ recebe o valor de $i$ e, por isso, se equivalem. Em relação ao primeiro estado de uma sequência, este recebe o vetor com as identificações dos jogadores (Figura 12).

Um conjunto de três estados não paramétricos é apresentado na Figura 11 e a posição dos jogadores nos estados de movimento de entrada e saída permite concatenalos: $\mathrm{E}_{1}(\bar{p}), \mathrm{E}_{2}(\bar{p}), \mathrm{E}_{3}(\bar{p})$, sendo que: i) a transformação de $\mathrm{E}_{1}(\bar{p})$ troca a posição de $\bar{p}[3]$; ii) a transformação de $\mathrm{E}_{2}(\bar{p})$ troca a posição dos três jogadores; iii) a transformação de $\mathrm{E}_{3}(\bar{p})$ troca a posição de $\bar{p}[2]$.

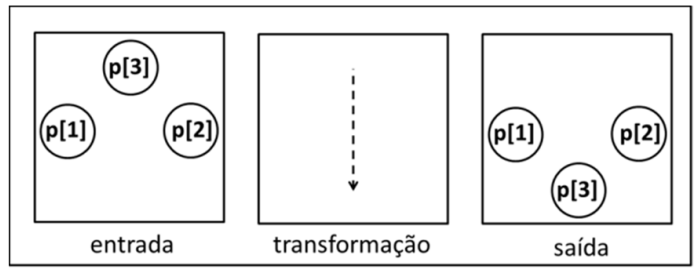

$\mathrm{E} 1(\bar{p})$

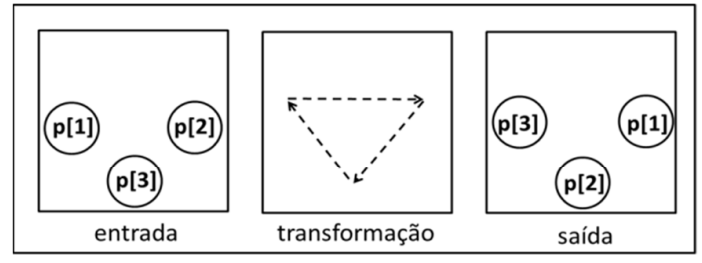

$\mathrm{E} 2(\bar{p})$

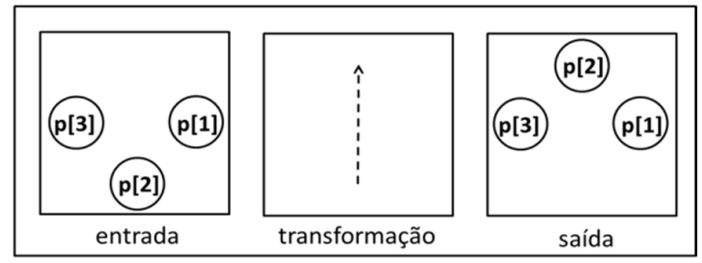

$\mathrm{E} 3(\bar{p})$

Figura 11: Um conjunto de três estados não paramétricos, denotados por $\operatorname{Ek}\left({ }^{-} \mathrm{p}\right)$, sendo k a designação do estado. Um círculo estáa na posição de uma tarefa representada por um índice $\mathrm{i}$ (i.e., $1 \leq \mathrm{i} \leq 3$ ) de ${ }^{-} \mathrm{p}$. ${ }^{-} \mathrm{p}[\mathrm{i}]$ representa a identificação de um jogador. No quadro intermediário de cada estado, uma seta pontilhada especifica a transformação. 
Um grafo estratégico construído a partir de estados paramétricos é um grafo estratégico paramétrico. Ambos os grafos são equivalentes, uma vez que todos os caminhos possíveis de ser executados em um podem ser executados no outro ou, de maneira equivalente, a sequência de estados de movimento que pode ser gerada pelos dois grafos é a mesma. Note que para cobrir todos os possíveis caminhos no grafo estratégico é necessário escolher um conjunto adequado de condições iniciais para o grafo estratégico paramétrico.

A Figura 12 ilustra um grafo paramétrico que utiliza apenas os estados de movimento de entrada e saída de $\mathrm{E}_{1}(\bar{p})$ da Figura 11. A partir dos estados de movimento de entrada e saída de $\mathrm{E}_{1}(\bar{p})$, assumidos agora como paramétricos, são gerados apenas três estados paramétricos.

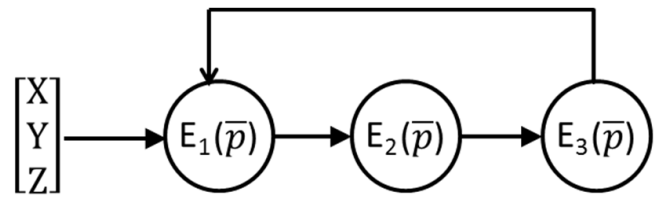

Figura 12: Um grafo estratégico paramétrico com a inicialização do estado E1(- p) pelos jogadores com as identificações X, Y, Z.

Em comparação à economia de estados gerada pela representação paramétrica, a Figura 13 apresenta a sequência de estados de movimento não-paramétricos gerada pelo grafo estratégico do estado de movimento-entrada de $\mathrm{E}_{1}(\bar{p})$, que é inicializado pelo vetor com as identificações de jogadores $[X, Y, Z]^{t}$ (Figura 12). A partir desta sequência de estados de movimento, é imediato escrever o correspondente grafo estratégico nãoparamétrico. O grafo não-paramétrico tem nove estados enquanto o paramétrico tem apenas três estados. A sequência principal do grafo paramétrico $\left(\left(\mathrm{E}_{1}(\bar{p}), \mathrm{E}_{2}(\bar{p}), \mathrm{E}_{3}(\bar{p})\right)\right.$ gera três estados não-paramétricos a cada interação: $(A, B, C),(D, E, F),(G, H, I)$. Em cada estado não-paramétrico, as identificações dos jogadores são denotados por X,Y e Z. Se as identificações das tarefas do estado de movimento-início são modificadas, um novo grafo estratégico é gerado pelo grafo paramétrico. 


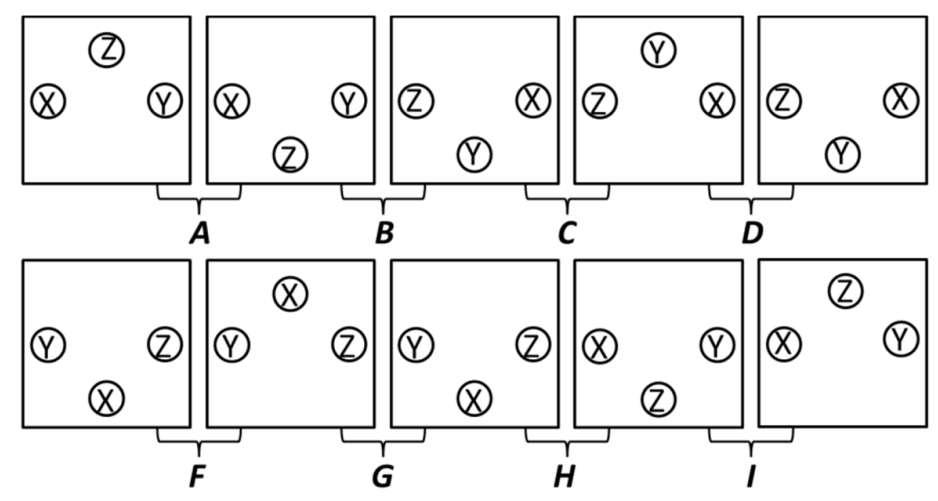

Figura 13: Sequência de estados de movimento gerada a partir do primeiro estado de movimento. Cada par adjacente de estados de movimento caracteriza um estado do grafo estratégico: A,B,..,I.

A representação do grafo estratégico descrita acima supõe que todos os jogadores podem desempenhar qualquer uma das tarefas. Entretanto, em geral, nem todo jogador é capaz de realizar todas as tarefas especificadas na transformação de um estado. Por isso, algumas permutações de tarefas não são permitidas e, consequentemente, não geram as respectivas conexões de estados. Estas exceções devem ser especificadas no estado de movimento-entrada, definindo, para cada tarefa, quais jogadores da equipe têm condições de desempenha-las. Portanto, o conceito de equivalência entre estados de movimento deve ser restringido. A equivalência de estados de movimento restringidos requer que em dois estados de movimento equivalentes, os jogadores alocados para cada tarefa sejam capazes de desempenha-las (i.e., o jogador é estrategicamente designado para desempenhar uma tarefa). Esta formalização é compatível com a maneira pela qual, na prática, se define estados que precisam ou não serem especificados.

A Figura 14a- $b$ apresenta, respectivamente, o grafo estratégico e o grafo estratégico paramétrico de uma variação da estratégia ofensiva em triângulos do basquetebol. Na parte $a$, os nós centrais e periféricos destacados representam estados que são iguais, exceto pelas distintas atribuições de jogadores às tarefas. Para cada nó periférico há um caminho destacado conectando o nó central a ele. Há outros caminhos que partem de cada nó periférico e retornam ao nó central ou a outro nó periférico. Estes caminhos indicam a circularidade da estratégia desenhada, que permite retornos a nós 
centrais depois de certa sequência de estados ser percorrida. Ainda, a partir de cada nó periférico há indicações de caminhos, cuja continuidade não é apresentada. Os estados implícitos na continuidade desses caminhos, se representados, possuem topologia semelhante à do grafo desenhado na Figura 14a. A diferença entre eles é que outros jogadores executarão as tarefas em cada um dos estados semelhantes. Por exemplo, tal como ocorre entre os estados A e D da Figura 13. Para possibilitar a visualização do grafo estes caminhos foram apenas indicados. Estes nós periféricos com continuações indicadas, assim como os nós centrais destacados no grafo não-paramétrico (Parte $a$ ), são representados pelo nó central no grafo paramétrico (Parte $b$ ). Isso porque no grafo paramétrico deixam de existir os nós periféricos dos quais partem caminhos semelhantes porém com outros jogadores em cada tarefa especificada nos estados. Neste caso, o nó central torna-se uma classe de equivalência para nós com esta característica, assim como os demais nós também são agrupados em classes de equivalência junto a seus semelhantes. Portanto, no grafo paramétrico, todos os caminhos destacados partem e retornam ao nó central.
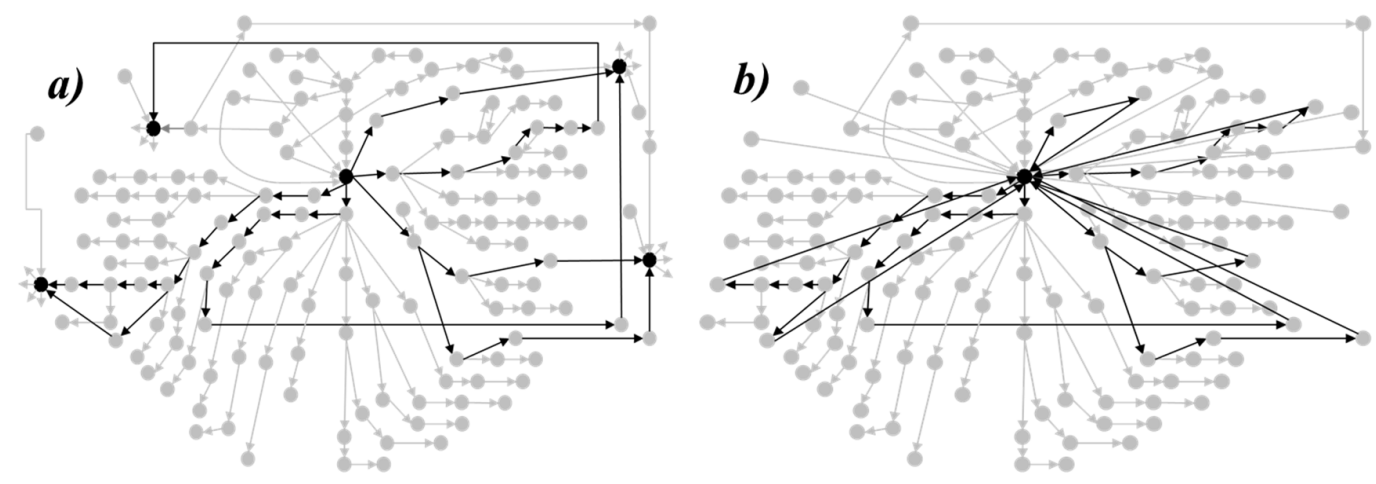

Figura 14: Comparação toplógica entre o grafo estratégico (Parte a) e o grafo estratégico paramétrico (Parte b). Na Parte a, os caminhos que partem do nó central em direção aos nós periféricos são destacados. Na Parte b, os caminhos fechados que passam pelo nó central são destacados. 


\subsubsection{Estrutura dinâmica da estratégia da equipe}

O estudo de algumas estratégias bem-sucedidas do basquetebol (e.g., ofensivas: triângulos, flex, shuffle; defensivas: individual, por zona e e mista) deram suporte à identificação de propriedades dinâmicas comuns e fundamentais para que a estratégia de uma equipe seja eficiente. A investigação dessas propriedades induziu à proposição de um modelo mais preciso da estratégia, baseado na adição de alguns delimitadores ao $\mathrm{EST}_{\mathrm{f}}$, que definem um conjunto ainda mais restrito de sistemas dinâmicos que o $\mathrm{EST}_{\mathrm{f}}$. Estes delimitadores aumentam a consistência do modelo e fornecem um direcionamento mais preciso ao desenho de uma estratégia pelo estrategista. Assim como o $\mathrm{EST}_{\mathrm{f}}$, esse modelo é compatível com estratégias de todos ECIs e denominado modelo da estratégia da equipe $\left(\mathrm{EST}_{\mathrm{M}}\right)$.

Uma característica comum às estratégias de basquetebol estudadas é que elas possuem um conjunto de especificações suficiente para conferir orientação para os jogadores em todas as fases do jogo. Uma fase do jogo é um sub-sistema particular do sistema "jogo" definido pelos critérios semânticos da posse de bola e região da bola. $\mathrm{O}$ fluxo dinâmico de um jogo evolui pelas seguintes fases do jogo: i) ataque/defesa, quando a equipe atacante pretende avançar e romper a defesa para obter uma oportunidade de finalização ou quando a equipe defensora pretende impedir uma vantagem posicional do adversário, protegendo seu campo de jogo e sua meta e procurando recuperar a posse da bola; ii) disputa ofensiva/disputa defensiva, quando a posse da bola encontra-se indeterminada em virtude de seu deslocamento fora do controle dos jogadores, por exemplo, após um arremesso ou chute. A dinâmica das fases ao longo do jogo é apresentada em um grafo chamado diagrama das fases do jogo (Figura 15). Qualquer fase pode ser interrompida se, por exemplo, ocorrer uma falta ou a bola sair da área de jogo. Há conexões diretas entre ataque/defesa e defesa/ataque $\left(\mathrm{X}_{\mathrm{Def}} / \mathrm{Y}_{\mathrm{Atq}}-\mathrm{Y}_{\text {Def }} / \mathrm{X}_{\mathrm{Atq}}\right)$, que são representadas no diagrama de fases do jogo por dois arcos interligando estes nós. Por exemplo, esta conexão pode ocorrer quando um jogador de defesa recaptura a posse da bola diretamente de um jogador do ataque. Além disso, ataque/defesa conectam-se de forma bi-direcional com a disputa $\left(\mathrm{X}_{\text {Def }} / \mathrm{Y}_{\text {Atq }}-\right.$ $\mathrm{X}_{\text {DptDef }} / \mathrm{Y}_{\text {DptAtq }}$ ou $\mathrm{Y}_{\text {Def }} / \mathrm{X}_{\text {Atq }}-\mathrm{Y}_{\text {DptDef }} / \mathrm{X}_{\text {DptAtq }}$ ), pois a posse da bola pode tornar-se indeterminada e, eventualmente, ser recapturada pela mesma equipe. Finalmente, 
disputa ofensiva/disputa defensiva conectam-se à defesa/ataque ( $\mathrm{Y}_{\text {DptDef }} / \mathrm{X}_{\text {DptAtq }}$ $\mathrm{X}_{\text {Def }} / \mathrm{Y}_{\text {Atq }}$ ou $\left.\mathrm{X}_{\mathrm{DptDef}} / \mathrm{Y}_{\mathrm{DptAtq}}-\mathrm{Y}_{\text {Def }} / \mathrm{X}_{\mathrm{Atq}}\right)$ em casos nos quais depois da posse da bola tornar-se indeterminada, a outra equipe a recaptura.

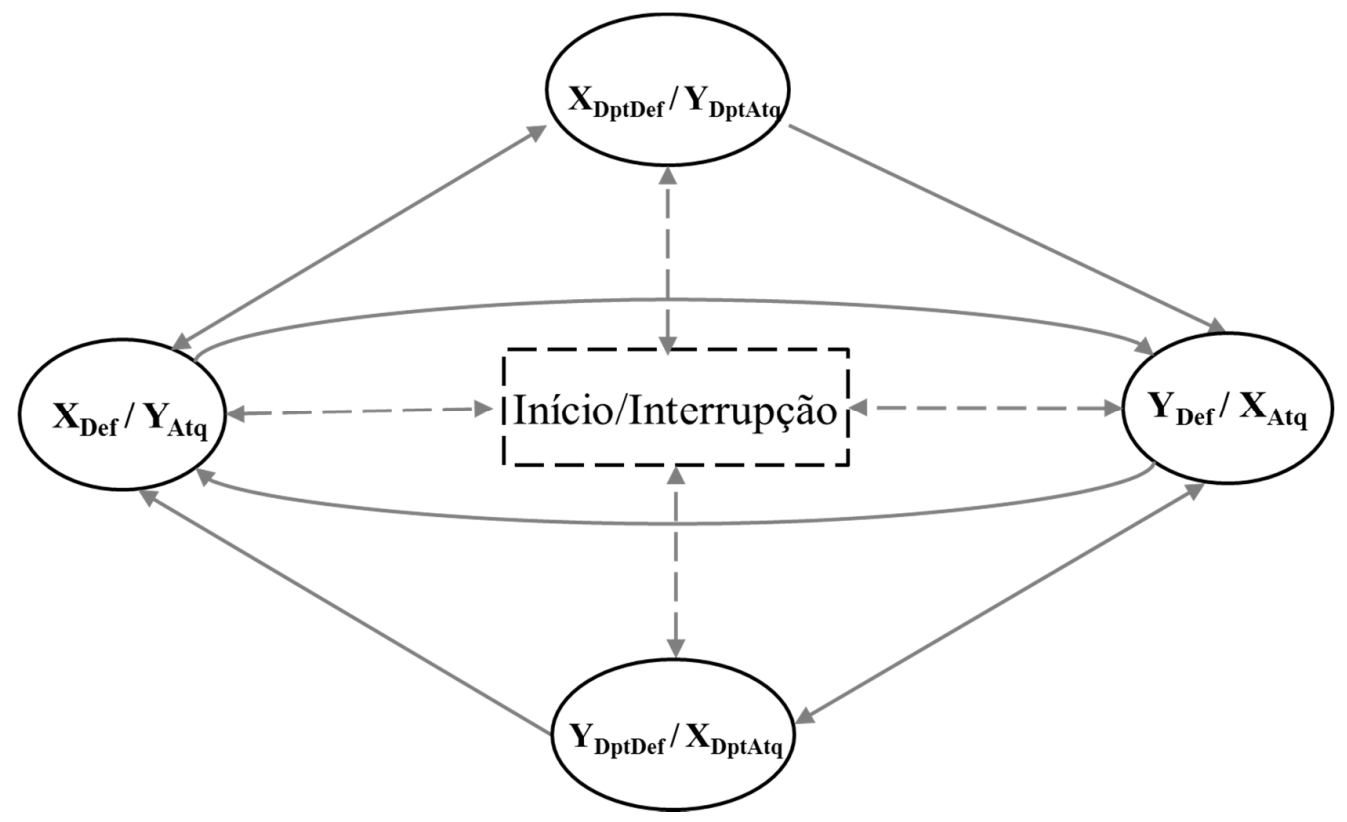

Figura 15: Diagrama das fases do jogo, no qual: Defesa X versus Ataque Y (XDef / YAtq); Disputa defensiva $\mathrm{X}$ versus Disputa ofensiva $\mathrm{Y}$ (XDptDef / YDptAtq); Defesa Y versus Ataque X (YDef / XAtq); Disputa defensiva Y versus Disputa ofensiva X (YDptDef / XDptAtq).

As fases do jogo e a dinâmica entre elas foram modeladas como delimitadores para definir o $\mathrm{EST}_{\mathrm{M}}$. Estes delimitadores são definidos por duas propriedades: i) cada fase do jogo induz um sub-grafo ${ }^{8}$ do $\mathrm{EST}_{\mathrm{M}}$ tal que os nós dos sub-grafos constituam uma partição ${ }^{9}$ dos nós de uma estratégia completa baseada no $\mathrm{EST}_{\mathrm{M}}$; ii) os sub-grafos são conectados de acordo com o diagrama das fases do jogo (Figura 15), tal que, dois

${ }^{8}$ Um grafo $H$ é um sub-grafo do grafo $G$ se e somente se o conjunto de nós e arcos de $H$ constituirem um sub-conjunto do conjunto de nós e arcos de $G$, respectivamente.

${ }^{9}$ Dado um conjunto $X$ e uma coleção $\mathbf{X}$ de sub-conjuntos de $X$. $\mathbf{X}$ é uma partição de $X$ se e somente se: i) $\cup \mathbf{X}=\mathrm{X}$; ii) $\forall A, B \in \mathbf{X}, A \cap B=\varnothing$. 
nós de distintos sub-grafos de duas diferentes fases podem ser conectados se e somente se houver uma conexão entre os nós correspondentes dos sub-grafos no diagrama das fases do jogo.

Os delimitadores das fases do jogo implicam uma decomposição do $\mathrm{EST}_{\mathrm{M}} \mathrm{em}$ sub-sistemas, com semântica e dinâmica próprias. Na sequência, as classes de subsistemas que representam cada fase do jogo serão estudadas e formalizadas, utilizandose estruturas de grafo.

Uma classe de sistemas dinâmicos pode ser caracterizada por propriedades topológicas dos grafos que a diferencie de outras classes. A estrutura topológica de uma família de grafos pode ser descrita por uma gramática formal ${ }^{10}$. A gramática de uma família de grafos é representada por dois elementos constitutivos: i) o conjunto de elementos a serem conectados, compostos de nós- $(m, n)$, nos quais $m$ e $n$ são, respectivamente, o número de conexões de entrada e saída de um nó; ii) as regras de conexão dos nós (FU, 1974). Na sequência, serão apresentados alguns elementos desta gramática.

No contexto do $\mathrm{EST}_{\mathrm{M}}$, serão apresentadas as classes de nós- $(m, n)$ e suas interpretações semânticas. Os seguintes tipos de nós-( $m, n)$ são observados: i) inicial; ii) organizador e decisão; iii) continuidade, iv) disputa. Na sequência, as propriedades topológicas e semânticas dos nós- $(m, n)$ serão apresentadas para as fases do jogo de ataque, defesa e disputa. Todos os tipos de nós- $(m, n)$ descritos logo acima existem no ataque e na defesa. A disputa tem um único tipo de nó- $(m, n)$ que é o organizador. Para este propósito, os grafos de uma estratégia ofensiva e outra defensiva no basquetebol, respectivamente, o ataque em triângulos e zona 2:3, serão revisados.

Um nó inicial (círculos brancos na Figura 16) é um nó-(0,1). Possui a propriedade que nenhum arco pode retornar a ele. Este tipo de nó especifica uma conexão no grafo a partir da qual um início ou re-início do jogo é possível. Um grafo

\footnotetext{
${ }^{10}$ Uma gramática formal é um objeto matemático que permite especificar uma linguagem, ou seja, é um conjunto de regras de formação de cadeias numa linguagem formal. As regras descrevem como formar as cadeias e são válidas de acordo com a sintaxe da linguagem. Uma gramática não descreve os significados das cadeias ou o que pode ser feito com elas em qualquer contexto.
} 
deve possuir diversos nós iniciais porque uma estratégia é especificada através de sequências de nós planejados para serem executados em intervalos de tempo entre interrupções do jogo. Assim, há um nó incial para cada distinta situação de re-início. Por exemplo, em vários ECIs, o conteúdo da estratégia pode orientar os jogadores da equipe, tanto no ataque quanto na defesa, durante: i) a primeira ação no início do jogo; ii) reposições laterais de bola; iii) um re-início após uma falta cometida.

Nós organizadores e de decisão são nós- $(m, n)$, com $m>1$ e $n>1$. Há dois tipos de nó organizador: i) organizador inicial e ii) organizador central. Em um organizador inicial (círculos pretos na Figura 16), as possíveis sequências que chegam a ele começam em um nó inicial. Por exemplo, no basquetebol, o início de um ataque através de um organizador inicial pode ocorrer na sequência de uma reposição da bola depois de uma cesta convertida ou de uma recaptura de bola depois de um arremesso errado. A partir de um organizador incial podem existir diversos caminhos, geralmente conduzindo a organizadores centrais. Os organizadores centrais (círculos pretos na Figura 16) são os principais atratores do $\mathrm{EST}_{\mathrm{M}}$, ou seja, eles são os nós de intersecção de diversos caminhos fechados. Eles fornecem várias alternativas para iniciar um caminho no grafo (i.e., uma jogada). Se a evolução em um caminho não é bemsucedida, pode ocorrer um replanejamento da ação da equipe através de um retorno ao nó organizador central. Na Figura 16, há apenas indicações das possíveis conexões que iniciam a partir de alguns nós organizadores. Estes nós organizadores originam as mesmas sequências de estados exceto pela atribuição de jogadores às tarefas que difere, uma vez que optou-se pela representação por um grafo não-paramétrico.

Um nó de decisão (círculos quadriculados na Figura 16) é um distribuidor, isto é, um nó no qual chegam alguns caminhos e do qual partem vários. Uma vez ocorrida a organização para a cooperação no nó organizador, um nó de decisão inicia uma dentre várias movimentações, que podem ser bastante diferentes entre si por se encontrarem em um ponto inicial a partir do qual múltiplos caminhos podem ser percorridos. A variedade de alternativas das movimentações resultantes aumenta a imprevisibilidade do comportamento de uma equipe para o adversário, pois múltiplas soluções podem ser originadas a partir desse nó. Por exemplo, no início da ação ofensiva no sistema de triângulos em um ataque posicionado no basquetebol, o jogador em posse da bola na lateral da quadra (um dos vértices do triângulo) tem como alternativas realizar um passe 
a cada um dos outros quatro jogadores. Para cada uma desses casos, a ação subsequente de todos os jogadores é distinta e dá origem a movimentações bastante diferentes entre si. Nós de decisão mais próximos ao final do caminho correspondem a uma movimentação que está mais próxima da sua finalização e, por isso, geram decisões com diferenças sutis, para lidar com os possíveis comportamentos do adversário. Por exempo, no ataque, pode ser planejado que o jogador com bola deva passa-la para um lado ou para o outro no final de uma movimentação, dependendo da posição do adversário, para obter uma oportunidade de finalização. Na defesa, pode ser o caso de realizar uma dobra defensiva no jogador com bola, ou não, em uma certa região da quadra para induzir a disputa da posse da bola e, possivelmente, recapturá-la.

Um nó de continuidade (círculo cinza na Figura 16) é um nó-(1,1). Faz parte de sequências de nós sem bifurcações. Por exemplo, quando alguns jogadores realizam uma sequência de passes contra uma defesa não-pressionante, caracteriza-se um momento trivial da oposição, no qual as duas equipes, no ataque e na defesa são orientadas por nós de continuidade. Nestes casos, não é necessário planejar ações alternativas. Um caso particular de nó de continuidade é o nó de finalização (círculos com periferia preta e centro branco na Figura 16). Uma vez atingido este nó, uma finalização é realizada. Um nó de finalização conecta-se a um nó de disputa.

Um nó de disputa (círculos com listras verticais na Figura 16) é um nó-(m,0). É atingido a partir de um nó de finalização ou decisão, depois de uma troca na fase do jogo do ataque para a disputa ofensiva e da defesa para a disputa defensiva, respectivamente. Na estratégia, tanto a disputa ofensiva quanto defensiva não conectam a nenhum outro sub-grafo porque o resultado desta fase não é previsível e pode levar a momentos nos quais a atuação ocorre a partir de uma orientação apenas tática, até que seja possível retomar a orientação estratégica, por meio de um organizador inicial, na fase em que a equipe se encontrar. Por isso, não há saídas planejadas desse nó (i.e., descrito como zero, em sua definição “ $m, n$ ” de entradas e saídas). Tanto para a estratégia ofensiva quanto para a defensiva, o conteúdo planejado dos nós de disputa especificam o reposicionamento dos jogadores a ser empregado, respectivamente, depois de uma ação planejada de finalização ou de recuperação da bola. 


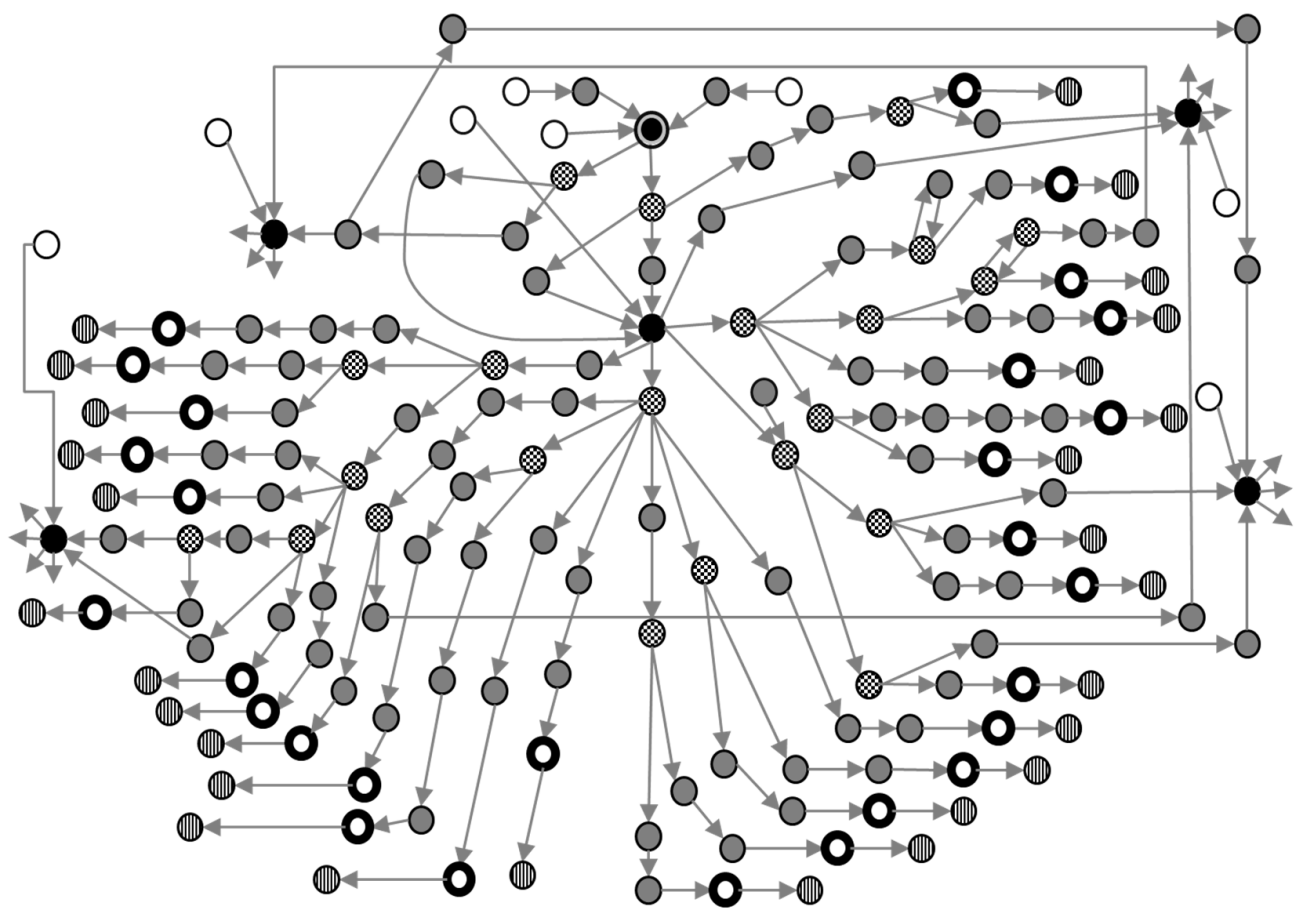

Figura 16: Um grafo que representa uma variação da estratégia ofensiva em triângulos.

No qual: $\bigcirc$ - nó inicial; $\bigcirc$ - nó de continuidade; $\bigcirc$ - nó organizador inicial; - nó organizador central; $\bigcirc$ h- nó de decisão; $\mathbf{O}$ - nó de finalização; (ID - nó de disputa.

Um grafo estratégico pode ser gerado pela aplicação de um conjunto de regras de conexão ao conjunto de nós descrito acima. Cada fase do jogo tem um grafo com uma estrutura topológica particular, que é gerada por um conjunto específico de regras de conexão. Por exemplo, estratégias ofensivas e defensivas têm conjuntos de regras de conexão distintas que produzem grafos com diferenças significativas em suas estruturas topológicas, que serão investigadas na sequência.

No ataque, há três diferentes sub-fases conhecidas: i) contra-ataque; ii) transição ofensiva e iii) ataque posicional. Nesta sub-seção, a mais complexa destas fases, o ataque posicional, é estudada. Um exemplo de estratégia para ataque posicional é a ofensiva em triângulos. No grafo desta estratégia, é observada a existência de múltiplos nós iniciais levando ao organizador central, que conecta-se a diversas opções de 
caminhos (Figura 16). Estes caminhos podem derivar para outros sub-caminhos e todos eles terminam em nós periféricos que especificam situações de finalização e reposicionamento dos jogadores. De maneira alternativa, um caminho pode retornar ao organizador central por outros caminhos, representando planos possíveis para quando uma sequência de nós não é bem-sucedida. Então, a partir do organizador central e dos seguintes nós de decisão, os jogadores podem tentar outra sequência de estados que leve a equipe a uma oportunidade de finalização. A estrutura descrita é fundamental para a especificação de qualquer estratégia ofensiva por duas razões principais: i) fornece a possibilidade de criar múltiplas alternativas ofensivas; ii) uma origem comum para as múltiplas alternativas ofensivas e a possibilidade de retornar a esta origem.

Com o objetivo de testar a consistência teórica da representação do $\mathrm{EST}_{\mathrm{M}}$ pelo grafo, foi realizado um estudo das propriedades topológicas fundamentais dos grafos de estratégias, resultando no denominado grafo esqueleto, que reúne elementos imprescindíveis para uma estratégia ser considerada adequada. Um grafo esqueleto é um sub-grafo não-paramétrico que possui reduzido número de nós e um conjunto de propriedades topológicas que são preservadas em uma família de grafos correspondentes a estratégias cuja semântica faz sentido para orientar uma equipe de um ECI.

Na perspectiva da fase do ataque da oposição, há três sub-fases conhecidas: i) contra-ataque; ii) transição ofensiva; e iii) ataque posicionado. Na Figura 17 a sub-fase mais complexa do ataque, o ataque posicionado, é representada por um grafo, de acordo com as estruturas topológicas descritas nos parágrafos anteriores, que tratam da estrutura de cada nó- $(m, n)$. Nesta figura, a sequência $(a, \ldots, c, d, e, f, \ldots, g, \ldots, e)$ representa um caminho que começa em um re-início do jogo (a), evolui por um nó organizador inicial $(c)$, um nó de decisão $(f)$, no qual um dentre alguns caminhos é escolhido e leva a outro nó de decisão $(g)$. O nó organizador central é uma vez mais alcançado $(e)$ com o intuito de iniciar um novo caminho, uma vez que o caminho que levaria à finalização não foi possível. Outro caminho alcança o organizador central $(e) \mathrm{e}$ evolui através de: $(f, \ldots, \ldots, i, n)$. No final deste caminho, outro nó organizador central (caminhos do grafo apenas indicados) é alcançado, levando ao prosseguimento por outro caminho. Quando o caminho alcança $i$, em caso de sucesso do ataque, segue para $j$ e $o$, completando o ataque com uma finalização. A sequência que parte de $f$ tem 
distintos finais possíveis, quatro deles são finalizações $(k, l, m, o)$ e dois são caminhos de retorno $(g, e, i, n)$.

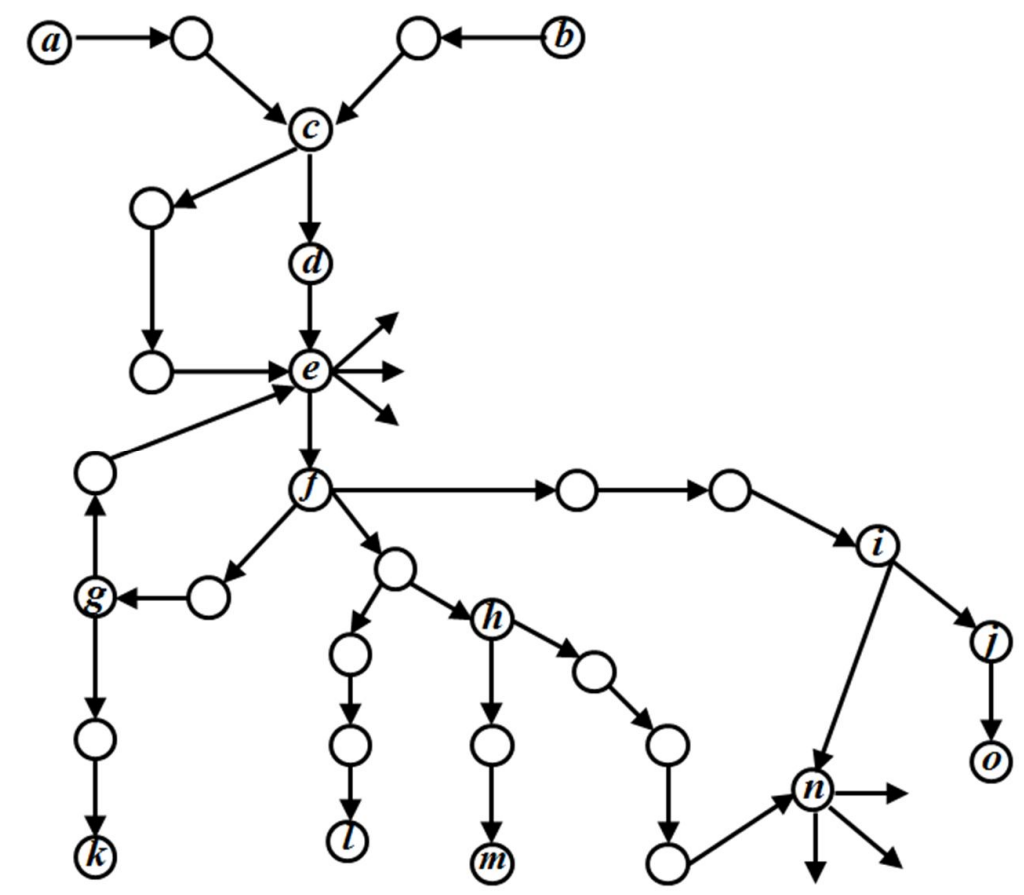

Figura 17: Grafo esqueleto de estratégias ofensivas.

Na defesa, há três sub-fases conhecidas: i) balanço defensivo, ii) transição defensiva e iii) defesa posicional, que ocorrem em oposição, respectivamente, às subfases ofensivas do contra-ataque, transição ofensiva e ataque posicional. De forma análoga ao estudo da estratégia ofensiva, a sub-fase defensiva mais complexa, a defesa posicional, será estudada. Um exemplo de defesa posicional é a zona 2:3. No grafo esqueleto desta estratégia (Figura 18), observam-se três nós iniciais que levam ao organizador central, que leva para diferentes opções de caminhos. Cada caminho pode derivar para outros sub-caminhos, entretanto, diferentemente do ataque, todos eles devem levar a um caminho de retorno para o organizador central ao invés de um nó de finalização ou de disputa. A estrutura descrita é fundamental para qualquer estratégia defensiva, pois fornece a possibilidade de re-organização eficiente da defesa para a maioria das alternativas criadas pelo ataque posicional adversário. 
No grafo esqueleto da Figura 18 , a sequência $(\alpha, \ldots, \gamma, \delta, \varepsilon, \zeta, \eta, \theta, \varepsilon)$ começa em um nó inicial $(\alpha)$, depois de um re-início, alcança um organizador inicial $(\gamma)$ e um organizador central $(\varepsilon)$, evolui através de um caminho definido após uma decisão $(\zeta)$ e retorna para um organizador central $(\varepsilon)$ com a possibilidade de evoluir por outro caminho. Em um exemplo da defesa zona 2:3 no basquetebol, $\alpha$ pode indicar um momento inicial da posse de bola, no qual a defesa no jogador adversário com bola seja realizada em toda a extensão da quadra enquanto os demais defensores ocupam suas respectivas regiões especificadas pelo sistema defensivo na meia quadra defensiva. $\gamma$ e $\delta$ podem indicar o retorno progressivo do defensor do jogador com bola para a sua região especificada na defesa zona e, com isso a equipe atinge o nó $\varepsilon$, que especifica a configuração coletiva organizadora, que dá o nome à defesa (i.e., 2:3). O caminho $\zeta$, $\eta$, $\theta$ pode indicar um rearranjo do posicionamento defensivo em função da circulação da bola pelo ataque da região central até a região próxima ao garrafão, retornando à posição inicial, o que faz a defesa se reposicionar novamente conforme a especificação do nó $\varepsilon$.

Em outro caminho, depois de alcançar o organizador central $\varepsilon$, a sequência segue através de $(\lambda, \mu, v, \xi)$. O $\eta$ é também um nó organizador, entretanto, com uma permutação dos jogadores em relação a $\varepsilon$. Assim, esta outra sequência pode conduzir a caminhos semelhantes no grafo, exceto pelos jogadores alocados para cada tarefa.

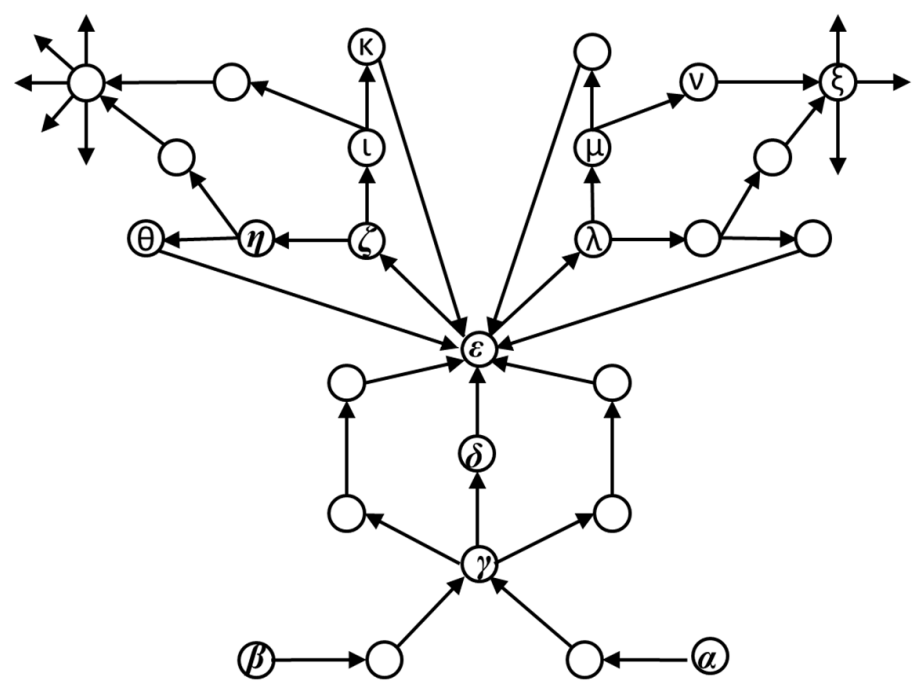

Figura 18: Grafo esqueleto de estratégias defensivas. 
A disputa ofensiva e a disputa defensiva são grafos desconexos (i.e., estes grafos não possuem arcos). A especificação estratégica dessas fases é resumida a um conjunto de poucos estados que posicionam os jogadores para recapturar a bola. Por exemplo, no basquetebol, uma situação de disputa ocorre no reposicionamento para um rebote depois de uma finalização. No futebol, uma disputa acontece no reposicionamento depois de um cruzamento.

O grafo estratégico completo é delimitado pelas fases do jogo e, consequentemente, contempla a todas elas (i.e., ataque, disputa ofensiva, defesa, disputa defensiva). Sua estrutura topológica é definida por dois sub-grafos complementares e desconexos: i) sub-grafo de ataque e disputa ofensiva e ii) sub-grafo de defesa e disputa defensiva. O alcance da disputa é estratégico. Por exemplo, no ataque, a disputa ofensiva pode ser alcançada depois de uma finalização e, na defesa, uma disputa defensiva pode ser alcançada depois de uma dobra no homem da bola. A partir das disputas ofensiva e defensiva, o jogo evolui para o confronto, orientado pelas especificações estratégicas do nó da disputa. Entretanto, o confronto pode ser alcançado a partir de qualquer outro nó estratégico devido às circunstâncias do jogo (e.g., uma bola perdida, um passe errado, etc). O retorno do confronto para o grafo estratégico ocorre através de uma conexão a um nó organizador que oferece múltiplas alternativas para a evolução da equipe orientada pela estratégia.

A dinâmica acima descrita explica o controle do jogo e indica quando a evolução é orientada por especificações estratégicas ou pela tática. Na Figura 19 esta dinâmica é apresentada. Nas partes superior e inferior da figura são ilustrados, respectivamente, os grafos esqueletos do ataque (Figura 17) e da defesa (Figura 18). No sentido longitudinal, a região central da figura contempla, no meio, na lateral esquerda e lateral direita, respectivamente, o confronto, a disputa defensiva e a disputa ofensiva (grafos desconexos representados por nós isolados). As linhas pontilhadas representam conexões entre a estratégia e a tática. O que é possível planejar em uma estratégia é a sequência de estados até o momento da disputa. Daí em diante a oposição segue através da tática (círculo cinza claro no centro da Figura 19), conforme indicado pelas linhas pontilhadas que ligam os nós de disputa ao nó central cinza, que representa a tática. A oposição segue pela tática até que seja possível se basear novamente nas especificações 
estratégicas da fase do jogo em que se encontre, conforme indicado pelas setas pontilhadas que retornam da tática para os nós das diferentes fases do jogo.

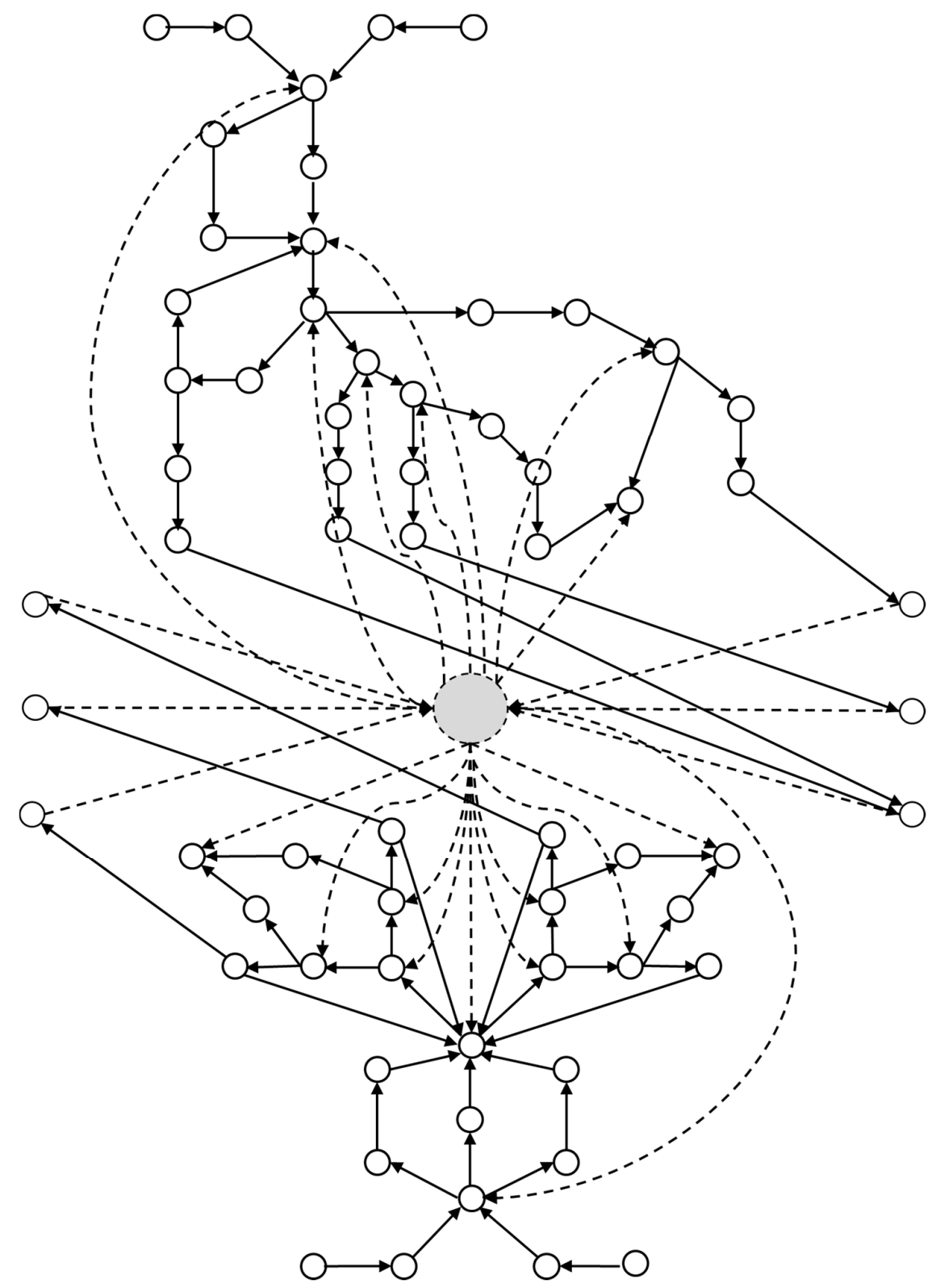

Figura 19: Integração dinâmica dos sub-grafos das fases estratégicas do jogo.

O conjunto de grafos ofensivos e defensivos que apresentam a estrutura topológica discutida acima constituem, respectivamente, as famílias de sub-grafos 
ofensivos e defensivos delimitadas pelo modelo da estratégia $\left(\mathrm{EST}_{\mathrm{M}}\right)$. Estas estruturas topológicas das estratégias ofensivas e defensivas induzem o conjunto essencial de caminhos para cada uma delas. Portanto, as estruturas topológicas constituem os delimitadores ofensivos e defensivos da estratégia.

Os delimitadores apresentados nesta sub-seção que definem o EST $_{M}$ são inspirados em três importantes propriedades: completude, diversidade e exequibilidade. Completude significa a existência de especificações estratégicas para todas as fases do jogo. Diversidade significa suficientes opções estratégicas para reagir a um vasto número de situações de jogo e dificultar a predição, pelo adversário, das ações seguintes da própria equipe. Finalmente, exequibilidade significa que as especificações são factíveis do ponto de vista cognitivo, técnico e físico, ou seja, os jogadores da equipe devem ser capazes de compreender, memorizar e executar as especificações estratégicas.

$\mathrm{O} \mathrm{EST}_{\mathrm{M}}$ é a família de estratégias no $\mathrm{EST}_{\mathrm{f}}$ que satisfaz os delimitadores definidos acima para as estratégias de ECIs. Entretanto, outros delimitadores definem famílias de estratégias contidas no $\mathrm{EST}_{\mathrm{M}}$, no contexto de um ECI específico. Um deles é conhecido pela expressão princípio de jogo. Por exemplo, no futebol, um princípio pode definir a estratégia de circulação periférica da bola com cruzamentos à área. Outro princípio pode definir o contra-ataque como estratégia ofensiva preferencial. Uma equipe de futebol pode priorizar o contra-ataque com circulação periférica da bola com cruzamentos à área, ou seja, esta estratégia utiliza os dois princípios descirtos anteriormente. Ainda, outro conceito que pode ser interpretado como uma família de delimitadores é conhecido como sistema de jogo da equipe (e.g., no futebol, o 4:4:2, 3:5:2, etc. No basquetebol, o ataque em Triângulos, etc.). Uma família de estratégias do $\mathrm{EST}_{\mathrm{M}}$ que contemple os delimitadores mencionados pode ser caracterizada, por exemplo, como um sistema 3:5:2 ofensivo que utilize preferencialmente o contraataque, com circulação periférica da bola. Portanto, os delimitadores restringem as possibilidades de especificações na estratégia de uma equipe.

Em uma estratégia, um número insuficiente de estados pode não permitir que se atinjam os objetivos do $\mathrm{EST}_{\mathrm{M}}$, pois o pequeno número de estados pode reduzir demais as alternativas de ação da equipe. Um grande número de estados aumenta muito as alternativas de ações da equipe, consequentemente, dificulta a compreensão pelos 
jogadores de todas as variedades estratégicas existentes. Considerando-se que o pequeno e o grande número de estados são representados, respectivamente, pelos números inteiros positivos $a$ e $b$, tal que $a \leq b$. Uma estratégia com um número equilibrado de estados deve ter $x$ nós, com $a \leq x \leq b$. A escolha do par de números $(a, b)$ depende do contexto, que é caracterizado pela experiência dos jogadores das duas equipes. Em um contexto de elevada experiência dos jogadores (e.g., nível profissional), os números $a$ e $b$ serão maiores que os respectivos números em um contexto de menor experiência dos jogadores (e.g., inciantes).

A complexidade de uma estratégia é o número total de decisões especificadas para uma equipe por sua estratégia. Esta medida de complexidade permite avaliar o grau de imprevisibilidade e dificuldade de aprendizado da estratégia. Tanto a imprevisibilidade quanto a dificuldade de aprendizado são diretamente proporcionais à complexidade da estratégia. Além disso, esta métrica também permite a comparação entre estratégias de diferentes equipes e mesmo entre estratégias de distintos ECIs. A complexidade da estratégia pode ser deduzida a partir do número de estados especificados.

Pela definição de estado, cada jogador toma uma única decisão a cada estado, por isso, o número de decisões especificadas para um jogador é igual ao número de estados na estratégia. Portanto, a complexidade de uma estratégia, com um conjunto $S$ de estados, de uma equipe específica de um ECI, com $n$ jogadores, é dada por $n|S|^{11}$.

\subsubsection{Metodologia hierárquica para desenho de estratégias}

Na seção anterior foi apresenta uma série de requisitos para definir propriedades fundamentais de uma estratégia adequada para orientar uma equipe de um ECI (i.e., delimitadas pelo $\mathrm{EST}_{\mathrm{m}}$ e não pelo $\mathrm{EST}_{\mathrm{f}}$, que é mais abrangente). Nesta seção, é proposta uma metodologia para desenhar estratégias que conservem estas propriedades.

A metodologia proposta consiste em uma abordagem hierárquica composta de cinco etapas: i) partição do conjunto de $n$ jogadores da equipe em $k$ partes, com $0<k \leq$

\footnotetext{
${ }^{11}|S|$ é a cardinalidade do conjunto $S$.
} 
$n$, na qual cada parte corresponde a uma UEST; ii) partição do campo de jogo em $k$ partes; iii) associação bijetora ${ }^{12}$ dos jogadores em cada UEST e partições no campo de jogo; iv) para cada conjunto de jogadores na partição, seleção das ações de uma UEST a partir de uma biblioteca de UESTs; v) concatenação das UESTs escolhidas.

Uma propriedade das UESTs de um estado é definir uma partição do conjunto de jogadores no campo de jogo, que induz uma partição particular do campo de jogo. Por exmplo, conforme ilustrado na Figura $20 a$ ), os jogadores $\{1,3,5\},\{2\}$ e $\{4\}$ constituem três diferentes UESTs. Na Figura 20b) as áreas da quadra de partição das UESTs são indicadas. Na Figura 20c), as ações das UESTs são indicadas. Esta propriedade das UESTs suporta a metodolgia proposta.

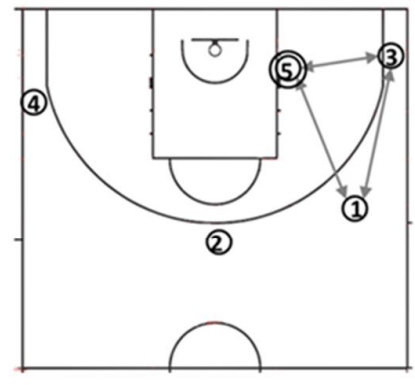

a)

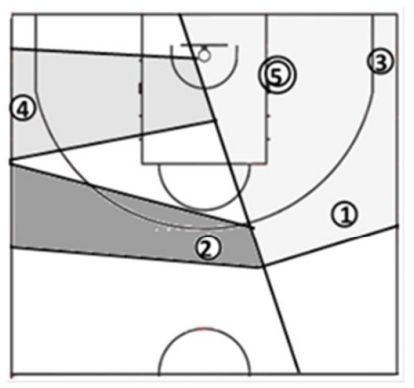

b)

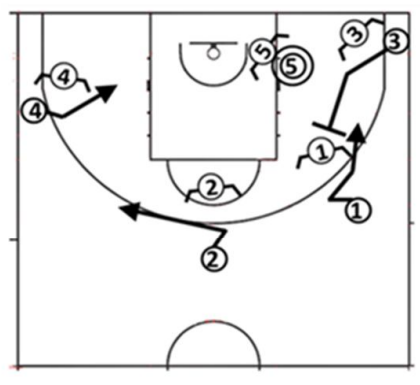

c)

Figura 20: Representação da constituição das UESTs pela partição dos jogadores das UESTs e associação da partição dos jogadores com a partição do campo de jogo. 20a) partição das UESTs, 20b) partição do campo de jogo, 20c) ações das UESTs.

A propriedade hierárquica da metodologia proposta é caracterizada por duas etapas sucessivas: i) a decomposição do conjunto de jogadores e área do campo de jogo; e ii) a definição das atividades em cada parte decomposta e sua integração. A seleção da especificação do estado, considerando todas as possíveis especificações, realizadas

\footnotetext{
${ }^{12}$ Uma função $\mathrm{f}: \mathrm{A} \rightarrow \mathrm{B}$ é bijetora se todos os elementos de $\mathrm{B}$ são imagens únicas dos elementos de
} A. 
pelas duas sucessivas especificações parciais descritas acima é menos complexa que uma especificação direta, que não tenha uma decomposição prévia. A razão para a complexidade do desenho hierárquico ser menor é que ele reduz o número de possíveis estados desenhados.

A decomposição hierárquica implica um estado ser definido através de um conjunto de UESTs envolvendo um pequeno número de jogadores. Assim, é possível construir uma biblioteca contendo UESTs pré-definidas com esta característica. Essas ações especificadas em bibliotecas são muito recorrentes nos estados.

Entretanto, as distintas combinações entre elas criam diversas especificações originais de estados. A existência de bibliotecas adequadas (i.e., funcionam e são suficientes) aumenta a plausibilidade dos estados especificados, pois UESTs plausíveis já foram desenhadas. Portanto, o estrategista deve apenas selecionar entre estas UESTs e formular suas concatenações.

Uma desvantagem desta abordagem hierárquica é não haver uma garantia teórica que todos os possíveis estados possam ser desenhados por esta metodologia. Entretanto, a análise de centenas de estados de duas estratégias clássicas (i.e., o ataque em triângulos e a defesa zona 2:3) não apresentou caso algum de estado que não pudesse ser desenhado por este método construtivo. Além disso, um estrategista parece adotar etapas semelhantes para especificar cada estado de sua estratégia. Portanto, não foram encontradas evidências intuitivas que esta metodologia não é suficiente para resolver o problema do desenho de estratégias.

Alguns dos objetivos definidos para um estado podem induzir uma partição particular do campo de jogo. Em um dado instante t, se houver alguns jogadores das duas equipes que, em um curto interval de tempo $\Delta \mathrm{t}$, podem interferir na progressão da bola, então a região ocupada por esses jogadores é denominada de região da bola. Em estados desenhados para lidar com forte oposição em torno da bola, uma das partes do campo de jogo deve ser a região da bola. Por exemplo, na Figura 21 há uma especificação na qual a região da bola é uma das regiões. Na Figura $21 a$, há as UESTs constituídas pelos jogadores: $\{1,5\},\{3,4\}$ e $\{2\}$. Na Figura 21b, o campo de jogo é particionado em três partes e uma delas é a região da bola. Na Figura 21c, são apresentadas as ações realizadas por cada UEST. 


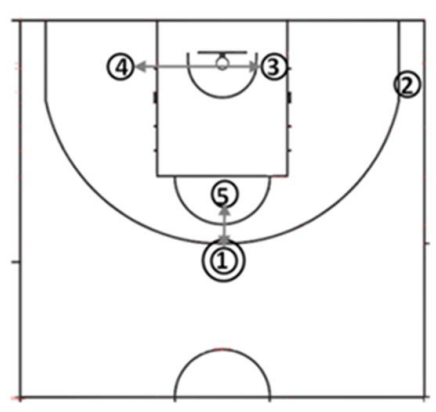

a)

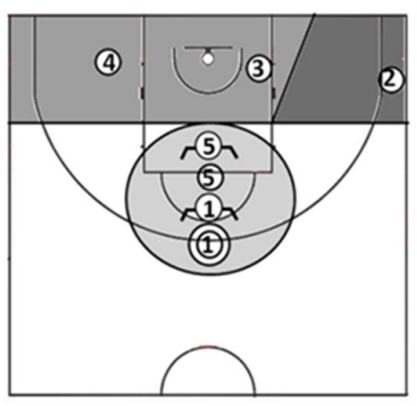

b)

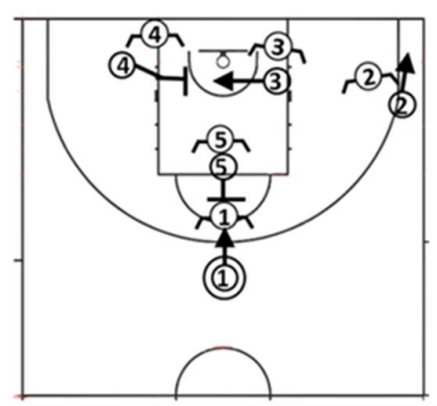

c)

Figura 21: Um exemplo de partição do campo de jogo, destacando o mapa de interações cooperativas (Figura 21a), a região da bola (Figura 21b) e as ações dos jogadores (Figura 21c).

\subsubsection{Discussão}

Atualmente, o desenho da estratégia de uma equipe depende principalmente da experiência da comissão técnica, pois não há uma teoria bem estabelecida para orientar esta elaboração. A principal contribuição teórica deste capítulo é a criação de uma abordagem formal para o desenho de estratégias de equipes de ECIs. Este modelo tem como elemento lógico fundamental a regra de ação, que descreve as decisões de um jogador. As regras de ação também são usadas para a especificação da transformação de um estado e, consequentemente, da sequência de transformações de estados em um $\mathrm{EST}_{\mathrm{f} .} \mathrm{O}$ número de nós do grafo que representam os estados do $\mathrm{EST}_{\mathrm{f}}$ pode ser reduzido se houver estados que diferem apenas pela atribuição de jogadores para o conjunto de tarefas. A síntese da representação da estratégia deve ser implementada através do conceito de estado paramétrico, que preserva todas as atribuições do estado mas não depende dos jogadores alocados para cada tarefa (i.e., jogador como parâmetro do estado). As propriedades estruturais que são requisitos para uma estratégia eficiente foram introduzidas na modelagem estratégica através de um conjunto de delimitadores (i.e., fases do jogo, tipos de conexões entre os nós por fase, regras de conexão, e regiões estratégicas), que especializam a definição da estratégia excluindo algumas estratégias do $\mathrm{EST}_{\mathrm{f}}$ que não atendem os delimitadores, definindo assim o $\mathrm{EST}_{\mathrm{M}}$. 
A modelagem realizada é suficiente para explicar a aplicação dinâmica das regras de ação durante uma situação do jogo. Isto constitui um avanço em relação à noção de uma estrutura lógica que orienta o comportamento dos jogadores já abordada em trabalhos prévios (GREHAIGNE \& GODBOUT, 1995; MCPHERSON, 1999a; MCPHERSON, 1999b; MCPHERSON, 2000). Na abordagem de GREHAIGNE e GODBOUT (1995) é utilizada a mesma expressão "regra de ação" que no presente estudo, embora com menos formalismo e sentido diverso, pois correspondem a orientações gerais de ação para diferentes situações da oposição e não especificações individuais, modificadas a cada mudança de estado, conforme proposto neste trabalho. Já McPHERSON (1999a; 1999b; 2000) apresenta os conceitos de perfil de eventos correntes e perfil de planos de ação, que descrevem o acesso e utilização de informações pregressas e do contexto presente para tomada de decisão e ação do jogador. Os conceitos apresentados por esses autores são úteis para o entendimento da estratégia, mas não tem completude no sentido de explicar todos os elementos presentes na estratégia de ECIs. Na modelagem aqui proposta a regra de ação é representada como a unidade fundamental de uma estratégia, sendo utilizada na formalização do estado.

Na perspectiva do presente modelo, o comportamento de jogadores experientes e iniciantes pode ser diferenciado pelo repertório de regras de ação e pela capacidade de processamento dessas regras. O jogador experiente é capaz de jogar com maior proficiência individual e coletiva por ser capaz de melhor memorizar e selecionar as regras de ação estratégicas e, em circunstâncias nas quais as regras de ação estratégicas não podem ser aplicadas, utilizar um repertório mais diversificado de regras de ação táticas. É importante observar que na maior parte do tempo de um jogo, um jogador planeja uma sequência de ações e promove ajustes à medida que a movimentação coletiva evolui. Este plano a priori para combinar um conjunto de ações sucessivas requer a modelagem de níveis de processamento mais abstratos de concatenação de conteúdos entre estados. Entretanto, a modelagem desses níveis de processamento mais alto esteve fora do escopo desse trabalho.

Uma característica importante do jogo e, consequentemente, do plano estratégico é a criação dinâmica, cooperação e re-criação de grupos cooperativos com os jogadores da equipe. A evolução dos grupos cooperativos constitui uma decomposição dinâmica da estratégia, que tem um importante impacto no seu desenho. A concatenação das 
regras de ação permite formalizar a noção de grupos cooperativos através do conceito de UESTs e suas interações.

No modelo proposto, uma regra de ação única deve ser especificada para cada jogador a cada estado, gerando uma ação coletiva unitária para a equipe. O critério adotado dá suporte ao desenho de UESTs e a coordenação entre elas em um estado. Se tanto a estrutura lógica (i.e., regras de ação) da especificação do estado quanto a dinâmica do estado (i.e., velocidade e aceleração dos jogadores) são consideradas, então o conceito de coordenação deve ser generalizado para orquestração do estado. Considerando que o conjunto de UESTs é conservado em um estado, então a reelaboração de UESTs requer que dois estados adjacentes sejam compreendidos.

A formalização do conceito de unidade estratégica e sua orquestração com as demais UESTs, a cada estado da estratégia, contribui para o avanço do entendimento teórico sobre a constituição e dinâmica de grupos funcionais, cujos parâmetros vêem sendo sistematicamente investigados tanto no contexto esportivo (PASSOS et al., 2008; PASSOS et al., 2011) quanto em outras áreas (FIORE \& SALAS, 2006; PEDERSEN \& COOKE, 2006) mas carecendo de uma formulação teórica mais abrangente que contextualizasse o conceito frente à estratégia e à tática da oposição. Além disso, o conceito de UESTs também constitui uma abordagem complementar aos estudos dedicados ao entendimento da representação coletiva do conhecimento, em um grupo funcional e na coordenação entre vários deles (CANNON-BOWERS \& BOWERS, 2006; REIMER, PARK \& HINSZ, 2006; RENTSCH \& DAVENPORT, 2006; WARD \& ECCLES, 2006). A contribuição para o entendimento do problema é demonstrada pela atual imprecisão conceitual (WARD \& ECCLES, 2006), evidenciada pelos múltiplos termos encontrados na literatura para descreve-lo: shared mental models, shared cognition, teamthink, team cognition (WARD \& ECCLES, 2006).

A representação da estratégia por meio de estados e sua imediata representação por meio de um grafo também não encontra precedentes na literatura sobre ECIs, até onde nos foi dado conhecer. Neste estudo foi ainda apresentada a possibilidade de utilização de estados paramétricos e o respectivo grafo paramétrico. Nesta representação, que tem os jogadores como parâmetro do estado, agrupa-se um conjunto de estados cujas tarefas especificadas são as mesmas, sendo diferentes apenas os jogadores que as realizam. Levando-se em conta a falta de qualificação de alguns 
jogadores para desempenhar certas tarefas, os estados que especificam associações inadequadas entre jogadores e tarefas não existem e, consequentemente, não são parte do estado paramétrico correspondente. A relação de adjacência entre estados paramétricos que define o grafo paramétrico é herdada do grafo estratégico: um estado paramétrico $A$ é conectado a um estado paramétrico $B$ se e somente se para cada estado de $B$ houver um estado de $A$ que se conecte a um estado de $B$ no grafo estratégico. $\mathrm{O}$ grafo estratégico paramétrico é mais compacto que o grafo estratégico pois reduz a redundância semântica por não repetir estados semelhantes, exceto pelos jogadores realizando cada tarefa. Esta propriedade é útil ao desenho e interpretação de estratégias pois conserva somente as informações semânticas relevantes para orientar estas tarefas. Trata-se de uma alternativa formal para representar a prática corrente em qualquer estratégia de limitar o conjunto de estados possíveis àqueles executáveis pelos jogadores da equipe. Embora amplamente empregado de maneira intuitiva por treinadores para que não ocorram especificações inadequadas de alocações de jogadores para tarefas às quais não estão aptos, não foi possível identificar na literatura outros estudos que tenham investigado esta nuance da estratégia dos ECIs. Portanto, a modelagem apresentada fundamenta uma linha de pesquisa que pode contribuir para um entendimento científico do processo de seleção de tarefas a serem executadas em função das características físicas, técnicas e táticas dos jogadores da equipe.

Os conceitos de estado e grafo, com suas respectivas representações paramétricas, definem a estrutura para o desenho de estratégias, o $\mathrm{EST}_{\mathrm{f}}$. Entretanto, o $\mathrm{EST}_{\mathrm{f}}$ pode permitir a especificação de uma família muito mais ampla de estratégias do que aquelas que representam estratégias eficientes. Por isso, os requisitos para o desenho de uma estratégia eficiente são caracterizados por um conjunto de delimitadores aplicado ao $\mathrm{EST}_{\mathrm{f}}$ com o intuito de gerar um sub-conjunto de estratégias que satisfazem os requisitos. A família resultante de estratégias é o $\mathrm{EST}_{\mathrm{M}}$, que é restringido por delimitadores que impõem algumas características necessárias para toda estratégia: completude estratégica para as fases do jogo e estruturas topológicas particulares do grafo.

As estratégias do $\mathrm{EST}_{\mathrm{M}}$ possuem três propriedades: completude, relativa às fases do jogo; diversidade, relativa às variações especificadas para cada jogada; e 
exequibilidade, relativa à capacidade dos jogadores de aprenderem e executarem a estratégia.

Há delimitadores adicionais que restringem o desenho da estratégia de acordo com as concepções estratégicas das diferentes comissões técnicas. Exemplos desses delimitadores são as noções bastante conhecidas de princípios de jogo e sistema de jogo. Verifica-se assim a existência de diferentes níveis de delimitadores, porém todos eles restringem as possibilidades de especificação de cada estratégia elaborada a partir do $\mathrm{EST}_{\mathrm{M}}$.

Os delimitadores do $\mathrm{EST}_{\mathrm{M}}$ podem ser aplicados à maioria dos ECIs. Entre as três classes de ECIs, finalização por lançamento à meta (e.g., basquetebol), finalização por arremate à meta (e.g., futebol de campo) e finalização por adentramento da meta (e.g., rugbi) (HUGHES \& BARTLETT, 2002) todos os esportes das duas primeiras classes e alguns da terceira satisfazem os delimitadores do $\mathrm{EST}_{\mathrm{M}}$. Nos esportes de finalização com adentramento da meta, a dinâmica do jogo enfatiza a conquista de território pois a progressão de um jogador atacante em posse da bola até a meta oposta é um requisito para pontuar. Em alguns desses esportes (e.g., rugbi) o contato físico com os defensores raramente leva à uma falta e estratégias alternativas devem ser especificadas para orientar a equipe nas circunstâncias nas quais o contato físico é intensificado (e.g., o maul no rugbi) e re-organizar a equipe nos momentos seguintes da oposição. Em outros esportes dessa mesma família (e.g., futebol americano), na eminência do contato com os defensores, a interrupção do jogo com uma falta é preferível a uma sequência de passes que conduziriam a um estado organizador da estratégia da equipe e subsequente reestruturação da mesma. A falta é uma opção melhor que a execução de uma jogada coletiva pois a primeira apresenta uma menor chance de perder a bola e, consequentemente uma chance maior de garantir o território conquistado, enquanto a segunda tem maior chance de perder a bola ou mante-la em uma posição menos favorável, caso uma falta seja cometida. Ainda, todo re-início depois de uma falta, independente da distância à meta, tem as mesmas regras, sendo vantajoso para a equipe em posse da bola estar mais próxima da meta adversária. Portanto, outro conjunto de delimitadores, que não os do $\mathrm{EST}_{\mathrm{M}}$, são requeridos para modelar a estratégia nesta subclasse de esportes. 
Este trabalho apresentou uma metodologia hierárquica para representar construtivamente uma estratégia do $\mathrm{EST}_{\mathrm{M}}$. Um conjunto de ações é representado pela concatenação de movimentos (i.e., produzido por regras de concatenação). Um conjunto de UESTs é representado pela concatenação de ações. Um conjunto de transformações é representado pela concatenação de UESTs. A concatenação de um sub-conjunto de estados compatíveis cria uma movimentação bem especificada. Assim, este procedimento construtivo é composto de cinco conjuntos de elementos ordenados em níveis hierárquicos: i) habilidades de movimentos básicos; ii) ações dos jogadores; iii) UESTs; iv) concatenação de UESTs na transformação do estado; v) concatenação de estados. Dessa forma, esta estrutura construtiva suporta o desenho de estratégias factíveis.

Neste estudo, foi também proposta uma medida de complexidade para estratégias: o número de decisões especificadas para cada jogador, indicado pelo número de estados de uma estratégia, pois cada estado prevê uma única regra de ação, logo uma única decisão, por jogador. Essa medida permite um tipo de comparação entre estratégias do mesmo ECI ou mesmo entre distintos ECIs. Além disso, constitui uma profícua abordagem para o treinador interessado em avaliar a estratégia de sua autoria. É possível identificar, em uma observação imediata, sua complexidade, e regiões de adensamento dessa complexidade, onde as movimentações desenhadas apresentam mais alternativas em comparação a outras regiões nas quais as sequências de estados são mais simples. Observa-se que a modelagem proposta suporta estudos quantitativos da complexidade das estratégias, além de ser útil para o uso imediato do treinador no cotidiano de treinamento.

A formalização do $\mathrm{EST}_{\mathrm{M}}$ apresentada neste trabalho estabelece uma metodologia para descrever, desenhar e avaliar a estratégia de uma equipe de um ECI. Porém, este modelo não esta finalizado e futuras investigações devem conduzir à definição de outros delimitadores e medidas de complexidade. Por exemplo, o diagrama de fases do jogo (Figura 15) pode ter as fases apresentadas decompostas em sub-sistemas que representem as interações entre sub-fases. Segundo BAYER (1986), no ataque há as sub-fases de conservação da posse da bola, desequilíbrio da defesa e finalização. Estes são conceitos não validados lógica e empiricamente, que podem ser testados e, 
eventualmente, aperfeiçoados com consequência sobre o refinamento do delimitador referente às fases do jogo. 
3.2 Modelagem do jogo em esportes coletivos de invasão

A pesquisa descrita nesta seção formaliza a relação entre as estratégias desenhadas para duas equipes oponentes e a dinâmica do jogo. As estratégias atuam como bases de dados acessadas para subsidiar as decisões dos jogadores de uma equipe e permitir que eles atuem coletivamente durante as diferentes circunstâncias da oposição. Os resultados constituem um avanço em relação a modelos existentes (REIMER, PARK \& HINSZ, 2006) nos quais a relação entre a estratégia e o jogo é discutida mas não formalizada (LAMES \& HANSEN, 2001; LEBED, 2007).

Após formalizado o sistema dinâmico que representa a relação entre estratégia e a oposição, no contexto do jogo, os elementos desse sistema foram decompostos, de forma hierárquica, levando em conta os principais módulos funcionais que compõem o fenômeno. A modelagem e documentação dos processos identificados foi realizada através de uma linguagem formal para representação de processos denominada Notação para Modelagem de Processos de Negócios (NMPN) (ERIKSSON \& PENKER, 2000).

A sub-seção 3.2.1 define as propriedades da família de sistemas dinâmicos composta pela integração das estratégias das equipes e a oposição no jogo. A sub-seção 3.2.2 apresenta a metodologia utilizada para representação desse sistema, sendo seu conteúdo separado em duas sub-seções: na sub-seção 3.2.2.1 é descrita a linguagem formal de representação dos processos do jogo; na sub-seção 3.2.2.2 são apresentados os módulos funcionais nos quais o jogo foi decomposto. As sub-seções 3.2.3 a 3.2.8 descrevem os módulos funcionais de conteúdos do jogo. Por fỉm, a sub-seção 3.2.9 retoma as contribuições centrais da pesquisa e apresenta as perspectivas futuras de estudo.

\subsubsection{Integração estratégia e jogo}

A relação entre as estratégias desenhadas para duas equipes e a oposição no jogo entre estas equipes pode ser formalizada como um caso particular de sistema dinâmico, no qual dois sistemas dinâmicos discretos, representados pelas estratégias das equipes, e um sistema dinâmico contínuo, representado pelo jogo, são integrados por fluxos de controle e dados. 
No modelo da estratégia apresentado na seção anterior, o $\mathrm{EST}_{\mathrm{M}}$ formaliza o estado como uma ponte entre um estado de movimento-entrada e um estado de movimento-saída, no qual uma transformação re-desenha as ações dos jogadores, as UESTs e sua orquestração. Cada transformação especifica uma única regra de ação por jogador e, consequentemente, cada jogador tem uma única ação especificada para ser executada por estado. Uma vez que as ações dos jogadores estejam completadas em um estado, uma transição de estados é necessária para que ocorra uma decisão e a definição de um novo objetivo para ser atingido pelas ações especificadas para cada jogador. Portanto, a estratégia é especificada através de estados conectados, sendo a decisão tomada em cada um deles a maneira pela qual um estado conecta-se a outro. Assim, a evolução do sistema no tempo ocorre através da conexão entre os instantes nos quais decisões são tomadas, caracterizando o sistema dinâmico que descreve a estratégia como discreto (ilustração da SC-ESTjogo, na Figura 22). Por outro lado, durante a oposição, no intervalo de tempo entre duas interrupções subsequentes, o jogo é contínuo e as equipes procuram realizar ajustes em seus comportamentos para aproximarem-se do conteúdo dos estados especificados nos instantes de decisão da estratégia. Dessa forma, o jogo é caracterizado como um sistema dinâmico contínuo, no qual cada alteração na configuração dos jogadores ou tarefa realizada significa uma modificação do sistema.

Cada modificação emergente do jogo, originada da interação entre as duas equipes, gera informação que é confrontada, via feedback, com o que havia sido planejado, conforme especificado na estratégia. Esta entrada leva à comparação da similaridade entre o estado do jogo e o estado mais próximo especificado em cada uma das estratégias. A partir do resultado da comparação o próximo objetivo da equipe é definido, considerando as alternativas oferecidas pela estratégia (Figura 22). 


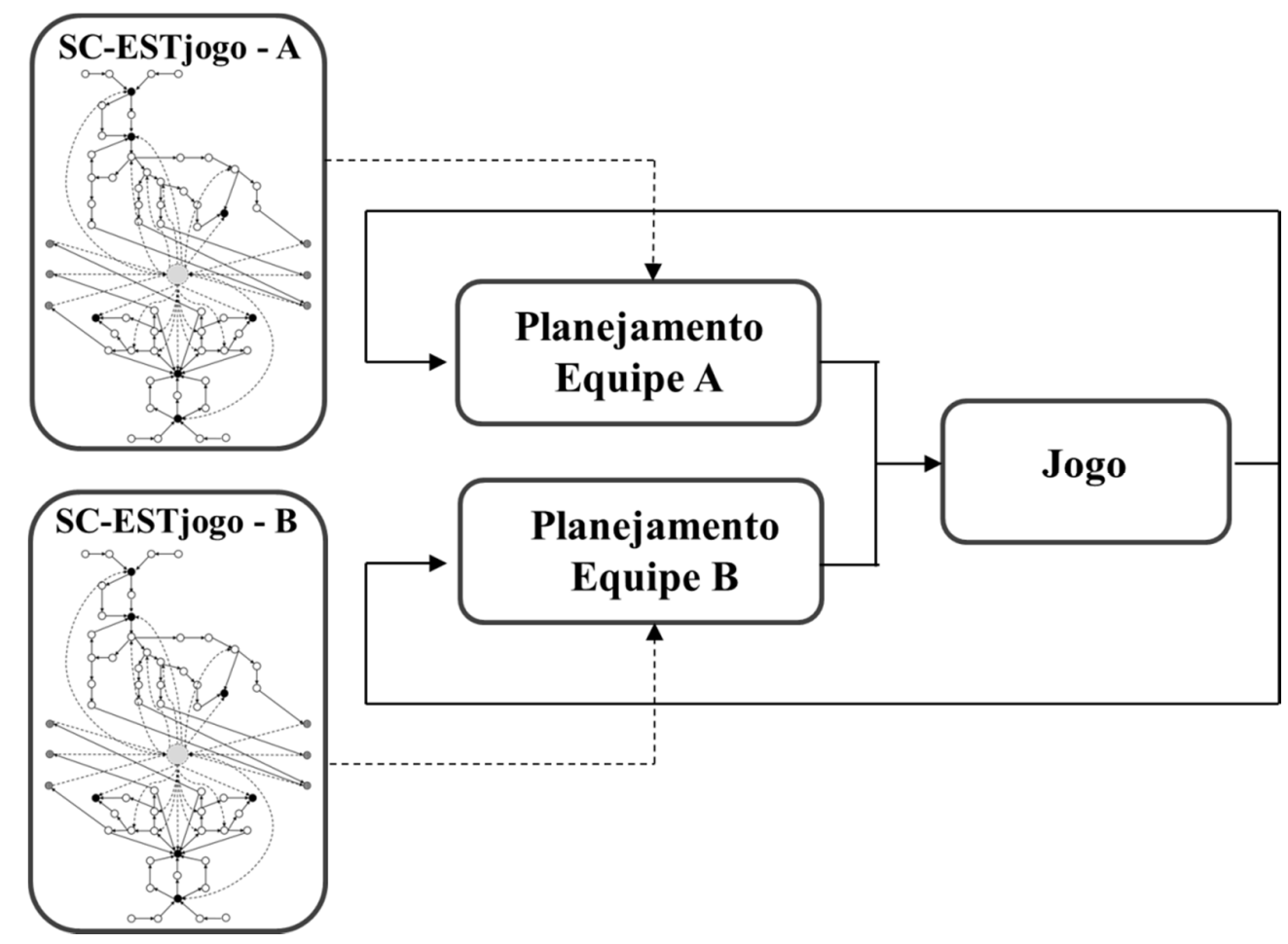

Figura 22: Representação do sistema controlado composto por dois sistemas dinâmicos discretos (estratégias das equipes A e B) e um sistema dinâmico contínuo (Jogo). As linhas pretas representam o fluxo de controle com retroalimentação. As linhas pontilhadas representam o fluxo de dado do SCESTjogo para o "Planejamento".

Para a modelagem da noção exposta de integração entre as estratégias das equipes e o jogo foi utilizado um modelo análogo ao do servomecanismo, descrito pela teoria do controle (OGATA, 1986) ${ }^{13}$. Três elementos centrais desta teoria compõem a estrutura fundamental do modelo apresentado nesta seção: i) controlador, ii) planta, iii)

13 Teoria do controle é um ramo interdisciplinar da matemática e engenharia que lida com o comportamento de sistemas dinâmicos. Em um sistema dinâmico com entrada externa e regulação via feedback, a variável de entrada sofre modulação para ser executada de maneira a gerar o efeito desejado na saída do sistema. Os eventuais ruídos na saída são usados via feedback para o cálculo do sinal de entrada subsequente. O funcionamento de um termostato ilustra este modelo. 
referência. $\mathrm{O}$ controlador é o elemento que calcula as especificações das atividades a serem executadas imediatamente. No contexto do presente trabalho, significa a decisão dos jogadores, a cada modificação do contexto da oposição. A planta é um arranjo de componentes físicos, de tal forma relacionados que constituem uma unidade. Assim, a planta é modelada neste trabalho como sendo as ações durante a oposição entre as equipes, cujos componentes físicos são as habilidades motoras executadas, cujo resultado é a definição de uma ação coletiva orquestrada. Finalmente, a referência é a entrada externa do sistema, que no presente contexto corresponde à estratégia de cada uma das equipes. O sistema modelado é fechado, uma vez que a ação do controlador depende do sinal de controle, originado na saída do sistema, com a informação do estado emergente do jogo. A informação do estado do jogo é utilizada conjuntamente com a entrada de um sistema dinâmico discreto, a estratégia da equipe. A estratégia caracteriza um sistema dinâmico discreto pois os estados são definidos apenas em pontos específicos no tempo. Os dados dos estados são utilizados como entrada a cada reinício de um intervalo de tempo contínuo do jogo, caracterizado pela oposição entre duas interrupções.

3.2.2 Metodologia de representação da dinâmica do jogo

A modelagem dos principais processos que descrevem a dinâmica do jogo foi representada na linguagem NMPN.

\subsubsection{Linguagem formal de representação dos processos do jogo}

Incialmente concebida para especificar processos de negócios, a NMPN possui um conjunto genérico de conceitos e possibilidades de modelagem que a torna aplicável à especificação de processos com alto nível de abstração em diversas áreas do conhecimento. As especificações NMPN são denominadas diagramas de processos de negócios (DPN). Um DPN é representado pelo uso de objetos de fluxo, artefatos e objetos conectores. O uso do formalismo da linguagem será exemplificado através de um fluxo que apresenta o processo competitivo em ECIs, considerando o jogo e sua 
relação com a estratégia. O fluxo indica ainda outros elementos do processo competitivo relacionados ao jogo, tais como o treinamento e a análise do jogo (Figura 23).

Objetos de fluxo, tais como processos e portas representam os principais elementos lógicos utilizados para definir o comportamento do fluxo. Um processo representa uma unidade de trabalho, que pode, ou não, ser decomposta em outros processos (e.g., o processo "Jogo" é decomposto na Figura 24). Portas podem ser de dois tipos: exclusivas e paralelas. Uma porta exclusiva é um local do processo no qual o fluxo pode tomar um de dois caminhos alternativos. Uma porta paralela é aplicada para sincronizar duas sequências de fluxo paralelas para um fluxo de saída comum. Um artefato fornece informação adicional sobre a execução de um processo. Um dado é o principal tipo de artefato, sendo utilizado para representar como uma certa informação é gerada e consumida por diferentes processos. A conexão entre um dado e um processo é descrita com um objeto de conexão. Objetos de conexão são de dois tipos: sinais de controle e associações, representadas por setas contínuas e pontilhadas, respectivamente. Sinais de controle conectam um processo a outro, indicando a ordem em que serão executados, enquanto associações conectam um processo a um artefato, indicando o processo do qual o dado foi originado. Todo processo tem seu início indicado por um círculo branco e seu fim indicado por um círculo cinza escuro, dos quais, respectivamente, parte e chega o sinal de controle. O término de um processo indica o final da decomposição dos conteúdos em dado nível. Os elementos gráficos que representam os conceitos descritos são indicados na legenda da Figura 23.

Na Figura 23, o evento "Início" comanda o início do processo e permite a execução do primeiro processo "Define EST $_{\text {jogo" }}$. Este processo indica o momento no qual a comissão técnica define a estratégia a ser utilizada contra o próximo adversário. A ESTj $\mathrm{j}_{\text {ogo }}$ delimita o conhecimento que jogadores e comissão técnica acessam durante o jogo, de modo a garantir uma atuação orquestrada entre os jogadores (i.e., atuação com uma orientação comum originada da estratégia) contra um certo adversário. Para tanto, ESTj $_{\text {ogo }}$ recebe o artefato dado-EST, representando o conteúdo total da estratégia, a partir do qual a $\mathrm{EST}_{\text {jogo }}$ será definida e produz o dado-EST $\mathrm{j}_{\mathrm{jog} .}$. Uma vez que a estratégia foi definida, o sinal de controle conecta ao "Treina EST jogo", indicando quando e como os jogadores praticam e aprendem as especificações a serem usadas no

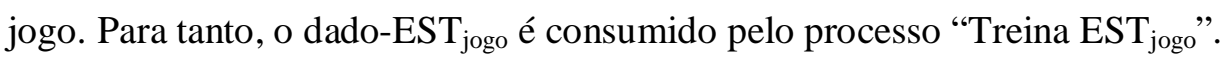


O período de prática da equipe perdura até o dia do jogo, que é indicado pela chegada do sinal de controle no processo "Jogo". Os comportamentos das equipes observados durante o jogo são os dados utilizados pelo processo "Análise de jogo", indicados pelo dado-padrões táticos. Os dados produzidos pela “Análise de jogo" geram relatórios utilizados para definição da estratégia para o próximo jogo. A existência de jogos futuros é verificada pelo teste Booleano "Fim da temporada?". Em caso negativo, o sinal de controle retorna para o primeiro processo, no qual a estratégia para o próximo

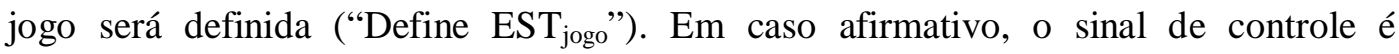
encerrado em "Fim" (círculo cinza escuro).

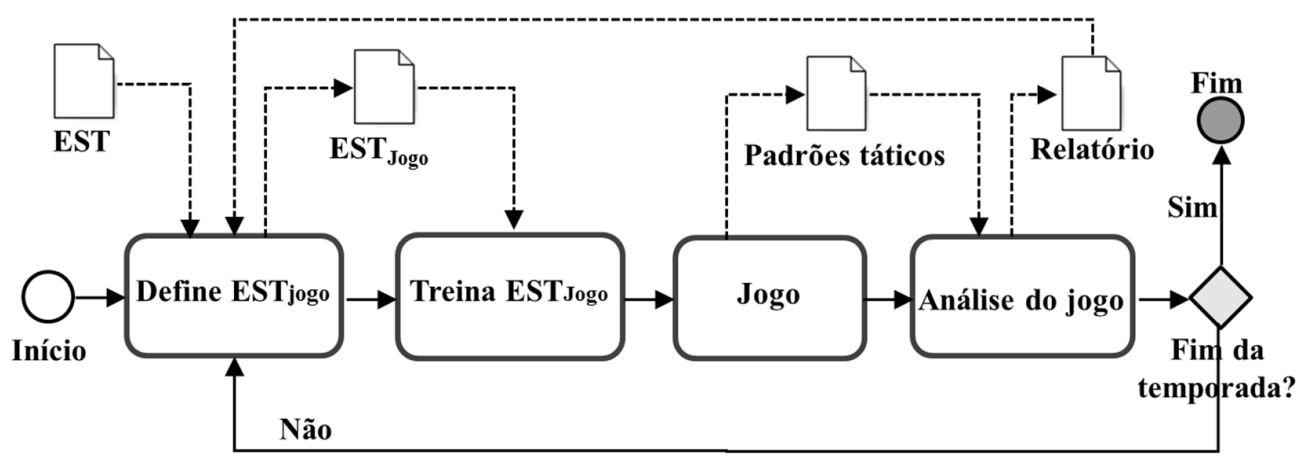

Figura 23: Processo competitivo em ECIs, com seus fluxos de controle e de dados, nos quais: retângulos são processos, losangos são testes Booleanos, estruturas em formato de papel são dados, setas contínuas são sinais de controle e setas pontilhadas são associações.

\subsubsection{Decomposição dos processos do jogo}

No modelo da dinâmica do jogo proposto (Figura 24), a estratégia concebida pela comissão técnica define a estrutura do comportamento inteligente coletivo de cada equipe e seus objetivos, sendo em cada momento do jogo interpretada e aplicada pelos jogadores. Na aplicação da estratégia, em certas circunstâncias os jogadores podem não ser aptos a responder adequadamente às exigências da oposição, o que pode levar à diminuição da orquestração da equipe. A estrutura da orquestração e as restrições 
impostas à ela pela oposição serão apresentadas na sequência, em seis processos distintos, conforme esquema da Figura 24. Todos os retângulos com texto em seu interior representam processos que serão decompostos. Os retângulos vazios são processos que não serão decompostos. Um sinal de controle conecta os processos (setas pretas).

O processo "Jogo" encapsula os demais processos do modelo (Figura 24, processo 1), e é decomposto em dois processos: i) "Planejamento da cooperação", que representa a decisão dos jogadores quanto a o que fazer, a partir da interpretação semântica do contexto do jogo e das especificações da estratégia (Figura 24, processo 2); ii) "Oposição", que representa a execução das ações definidas no planejamento (Figura 24, processo 3). O processo Planejamento da cooperação é decomposto em três outros processos: i) Comparação de estados, que verifica a similaridade entre o estado real do jogo e os estados previstos na estratégia (Figura 24, processo 4); ii) Planejamento da movimentação, que planeja uma nova movimentação em caso da equipe precisar reformular sua atuação, devido a uma desestruturação coletiva devido à oposição ou devido ao término da movimentação anterior (Figura 24, processo 5); iii) Planejamento do estado, que produz as especificações de ações dos jogadores do estado da estratégia que deverá orientar a ação dos jogadores no momento seguinte (Figura 24, processo 6). 


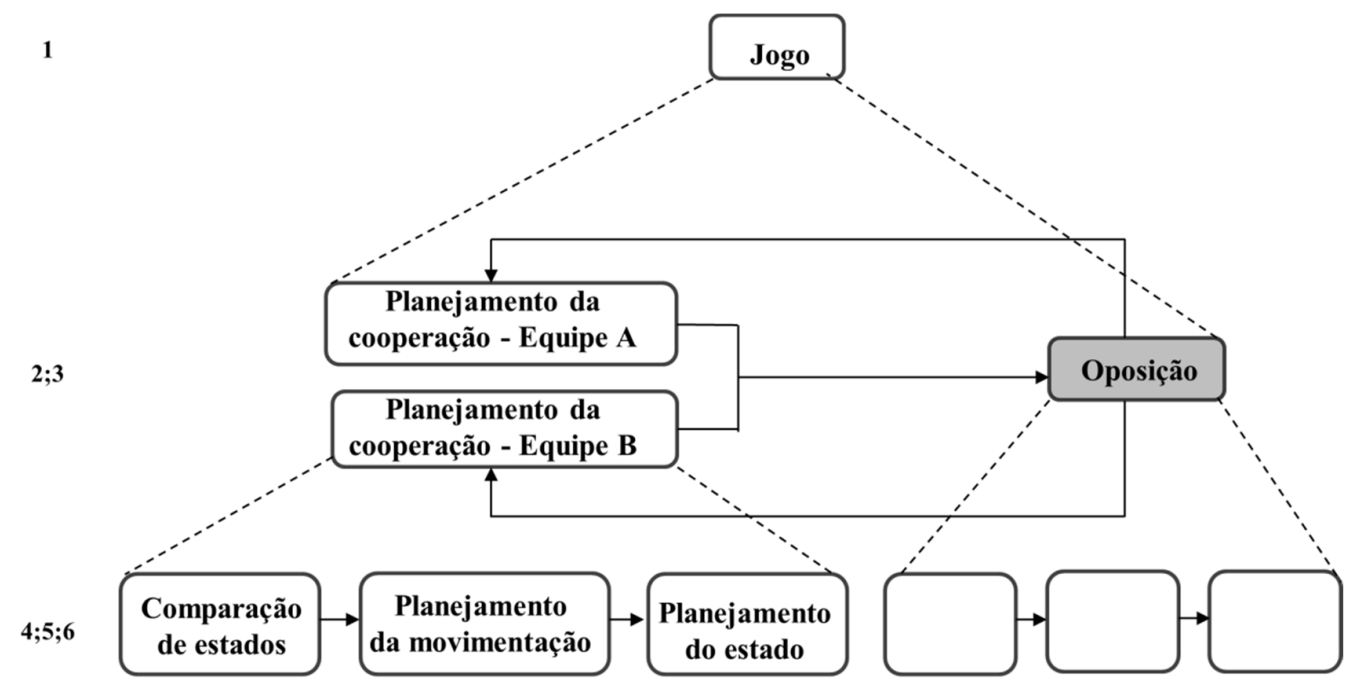

Figura 24: Representação esquemática da decomposição do "Jogo" em seis níveis hierárquicos. Onde: 1. "Jogo"; 2. "Planejamento da cooperação" (primeiro processo do "Jogo"); 3. "Oposição" (segundo processo do "Jogo"); 4. “Comparação de estados"; 5. "Planejamento da movimentação"; 6. "Planejamento do estado". Processos sem legenda não são decompostos no modelo.

Uma vez apresentadas a estrutura de decomposição da dinâmica do jogo e a linguagem formal utilizada, os processos decompostos serão detalhados.

\subsubsection{O jogo}

A representação do "Jogo" é iniciada com o "Posicionamento inicial no campo de jogo" (Figura 25). Este processo tem como entrada os dados referentes ao subconjunto da estratégia completa (dado-SC-ESTjogo) de cada uma das equipes (A e B), que as respectivas comissões técnicas decidem utilizar em um jogo específico. Em um exemplo, supondo que para enfrentar certa equipe, identifica-se que defesa por zona não é uma alternativa adequada, então no dado-SC-ESTjogo selecionado para esta partida, as sequências de estados da estratégia da equipe correspondentes à defesa por zona não serão incluidas. Com isso, no âmbito defensivo, o sub-conjunto da estratégia será 
constituído por outras defesas que não por zona. O "Posicionamento inicial no campo de jogo" recebe como entrada também o dado- $\mathrm{J}_{\mathrm{i}-1}(\mathrm{i}>0)$, referente à semântica da última intervenção do árbitro (e.g., marcação de uma falta, violação ou uma bola que saiu pela lateral após um passe errado), que influi diretamente no tipo de posicionamento para o reinício (e.g., no futebol, é bastante diferente o posicionamento para reinício com um escanteio ou com tiro de meta). Com estes dados de entrada, é calculado o posicionamento no campo de jogo a ser empregado para o próximo intervalo da oposição. Note que a representação do jogo aqui realizada corresponde a cada intervalo entre interrupções. Assim, o primeiro intervalo representável é o período transcorrido entre o início do jogo e a primeira interrupção pelo árbitro. $\mathrm{O}$ índice $\mathrm{i}>0$ do dado- $\mathrm{J}_{\mathrm{i}-1}$ implica valor zero para o dado- $\mathrm{J}_{\mathrm{i}-1}$ na primeira iteração do fluxo, pois tratase do início do jogo, ou reinício de um dos seus períodos, e não há informação a ser transmitida. Nas iteradas subsequentes do fluxo, o dado terá algum valor semântico pois a interrupção que leva à necessidade de um novo posicionamento para o re-início terá ocorrido como consequência de algum tipo de intervenção do árbitro. A saída do processo é o dado- $S_{\mathrm{i}}$ que especifica os parâmetros do estado caracterizado (i.e., região ocupada por cada jogador no campo de jogo, dinâmica dos jogadores e da bola e posse da bola).

O processo seguinte representa a definição do plano de cooperação entre os jogadores da equipe. Quando "Jogadores planejam cooperação" ocorre imediatamente após o início do jogo, o processo especifica um plano apenas para os primeiros instantes da oposição, até que a posse de bola e a configuração de ambas equipes no campo de jogo seja estabelecida. Nos re-inícios seguintes, este processo definirá planos de ação podendo envolver sequências mais ou menos longas de estados a serem executadas durante a oposição. Para tanto, "Jogadores planejam oposição" utiliza o dado- $\mathrm{S}_{\mathrm{i}-1}(\mathrm{i}>0)$, sendo que o valor zero da primeira iterada corresponde à informação do posicionamento inicial, que antecede o reinício da oposição. Como saída, o processo que efetua o planejamento da cooperação devolve as regras de ação que cada jogador deverá seguir para execução do próximo estado da sequência planejada.

O fluxo é então sincronizado e entra no processo "Oposição", indicando o enfrentamento entre as equipes. O dado-regras-de-ação das duas equipes é a entrada da “Oposição”, indicando o conjunto de declarações lógicas do tipo: se <condição>, então 
$\langle a c ̧ a \tilde{o}\rangle$, especificadas para cada jogador, que orientarão seus comportamentos nos instantes seguintes. $\mathrm{O}$ dado- $\mathrm{S}_{\mathrm{i}-1}$ também é entrada deste processo, pois a oposição entre as equipes ocorre a partir do contexto atual, descrito pelos parâmetros do estado presente. A saída da "Oposição" é o dado- $\mathrm{S}_{\mathrm{i}}$, que representa o estado produzido pelo jogo, após a interação das equipes.

$\mathrm{Na}$ sequência, o processo “Árbitro verifica as ações” recebe como entrada $\mathrm{S}_{\mathrm{i}} \mathrm{e}$ indica o momento em que o resultado das interações na oposição é analisada. Em caso de necessidade, o árbitro pode interceder e interromper o jogo, conforme indicado pela sequência do fluxo, ao passar pelo teste Booleano "Interrupção?". Caso não haja interrupção, o fluxo retorna para "Jogadores planejam cooperação", onde o estado seguinte será especificado por meio da definição das regras de ação de cada jogador. Em circunstâncias nas quais o árbitro interrompe o jogo, o tipo de interrupção é comunicada, conforme indica a sequência do fluxo para "Árbitro descreve tipo de interrupção". Este processo gera o dado- $\mathrm{J}_{\mathrm{i}}$, que será novamente utilizado no "Posicionamento incial no campo de jogo". 


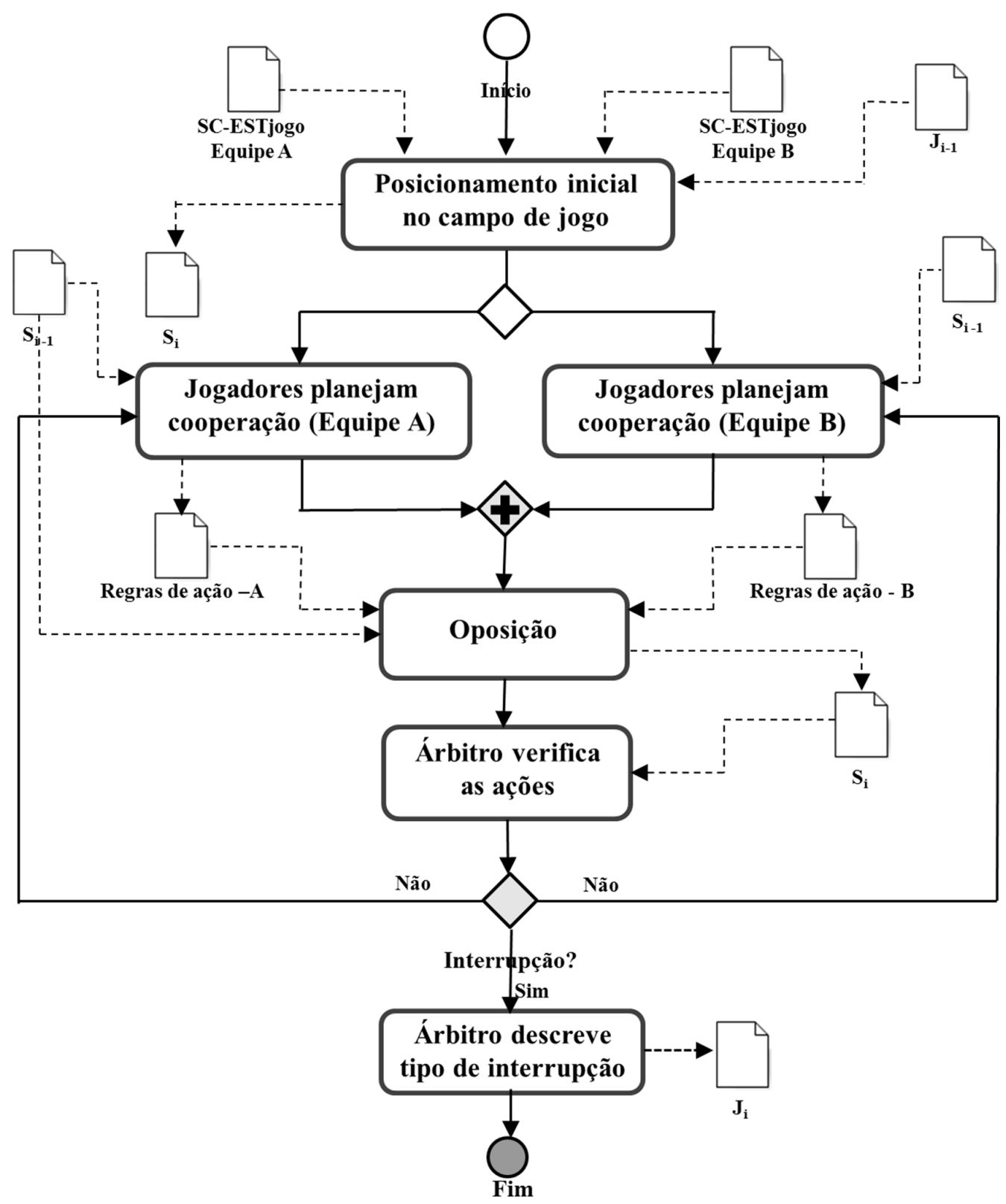

Figura 25: Processo "Jogo": fluxos de controle e de dados, nos quais: SC-ESTjogo: Sub-conjunto da estratégia para o jogo; Si-1 e Si: dados referentes aos parâmetros do estado do jogo atual e do estado gerado após a oposição, respectivamente; Ji-1 e Ji: dados referentes à semântica da intervenção do árbitro no momento atual e após a oposição, respectivamente. 


\subsubsection{Planejamento da cooperação da equipe}

Conforme descrito no fluxo da Figura 25, "Jogadores planejam cooperação" pode ocorrer, de maneira alternativa, a partir de dois caminhos do fluxo de controle. Esta representação indica que o planejamento acontece tanto em uma situação de reinício, quanto durante a execução de uma movimentação coletiva da equipe. Portanto, ao ser decomposto o processo "Planejamento da cooperação", conforme ilustrado na Figura 26, a primeira etapa lógica a ser representada é a verificação da existência de um planejamento corrente ou a necessidade de se criar um para que a equipe possa seguir jogando. O processo "Jogadores verificam término do planejamento" representa assim, a verificação que os jogadores realizam após completarem cada interação durante o jogo.

Caso seja constatada a existência de um planejamento corrente (resposta afirmativa para o teste Booleano: Existe planejamento corrente?), "Comparação de estados" representa o momento em que os jogadores comparam o estado real produzido pela oposição com o estado pretendido, conforme especificado no planejamento corrente. Para realizar esta comparação dois dados são utilizados: dado- $\mathrm{S}_{\mathrm{i}-1}$ e dadoestado-de-movimento-saída, respectivamente, referente ao estado do jogo constituído com a interação entre as equipes que acabara de ocorrer e o estado do planejamento corrente que se pretendia atingir.

A constatação de existência de similaridade entre os estados (resposta afirmativa ao teste Booleano "Estados similares?") leva ao processo “Acessa próximo estado". Este processo tem a entrada do dado-Planejamento-corrente, que indica o conhecimento do plano estratégico corrente pelos jogadores para a escolha do próximo estado. Como saída, o processo gera o dado-regras-de-ação, que extrai do planejamento as especificações de ação do estado subsequente a ser realizado e o dado-Planejamentoatualizado, que atualiza o planejamento desconsiderando o estado que será executado na sequência. O dado-Planejamento-atualizado torna-se o dado-Planejamento-corrente na próxima iterada do fluxo, sendo utilizado no processo "Jogadores verificam término do planejamento" e no próprio processo em que foi gerado "Acessa próximo estado", pois é o dado necessário para indicar o estado vigente, do qual será feita a extração das regras de ação a serem executadas no momento seguinte da oposição. Caso haja um 
planejamento corrente mas os jogadores tenham divergências na interpretação da similaridade entre o estado do jogo e o estratégico, realizado no "Comparação de estados", a resposta ao teste Booleano "Estados similares?" será negativa e um novo planejamento de movimentação deverá ser gerado.

A partir do primeiro teste Booleano (“Existe planejamento corrente?"), o outro possível caminnho do fluxo ocorre quando a resposta é negativa, indicando ausência de planejamento corrente. A ausência de planejamento corrente pode ser atribuída a uma dentre duas diferentes causas. Primeiro, não haver planejamento ocorre quando a equipe retorna de um período em que atuou a partir da tática, na maioria das vezes em decorrência da capacidade do adversário de desestruturar a ação coletiva da equipe. Então, o momento em que a equipe consegue se preparar para a reorganização é representado pela execução do processo "Planejamento da movimentação". A segunda causa é a finalização da movimentação que vinha sendo executada, uma consequência das movimentações (i.e., sequências de estados) poderem ser planejadas apenas nos intervalos entre estados de decisão ou entre um estado de decisão e outro de finalização. Toda vez que a equipe alcança um estado de decisão há necessidade de replanejamento da movimentação, pois há mais de um possível caminho a seguir. Em qualquer um desses casos o fluxo é desviado para o processo "Planejamento da movimentação".

O planejamento da movimentação seguinte requer coordenação das decisões dos jogadores. Quando estes são incapazes de convergir em suas decisões quanto ao plano a seguir, o planejamento da movimentação não é bem-sucedido. Este ruído na decisão coletiva pode ocorrer por falhas na interpretação dos contexto ou falhas na comparação deste com a referência estratégica. Tais erros podem ser, muitas vezes, induzidos pela pressão espaço-temporal imposta pela oposição. Nestas situações, o processo é finalizado uma vez que a sequência do jogo ocorre no âmbito tático, onde as ações individuais não estarão orquestradas entre si. A equipe seguirá atuando taticamente até que se consiga planejar nova movimentação, o que no fluxo é descrito pelo caminho que inicia no "Jogadores verificam término do planejamento" e, com a resposta negativa ao teste "Existe planejamento corrente?"segue para "Planejamento da cooperação". Por outro lado, em caso de sucesso (resposta afirmativa ao teste Booleano "Êxito no planejamento?”), ocorre o planejamento de nova movimentação e o fluxo segue para o processo “Acessa próximo estado", para que o próximo estado possa ser acessado. 
Conforme descrito na explicação sobre o caminho realizado quando a resposta é afirmativa ao teste "Estados similares?", este processo utiliza o dado-Planejamento corrente para indicar o contexto no qual o próximo estado deverá ser acessado, tendo como saída as regras de ação que serão utilizadas na oposição.

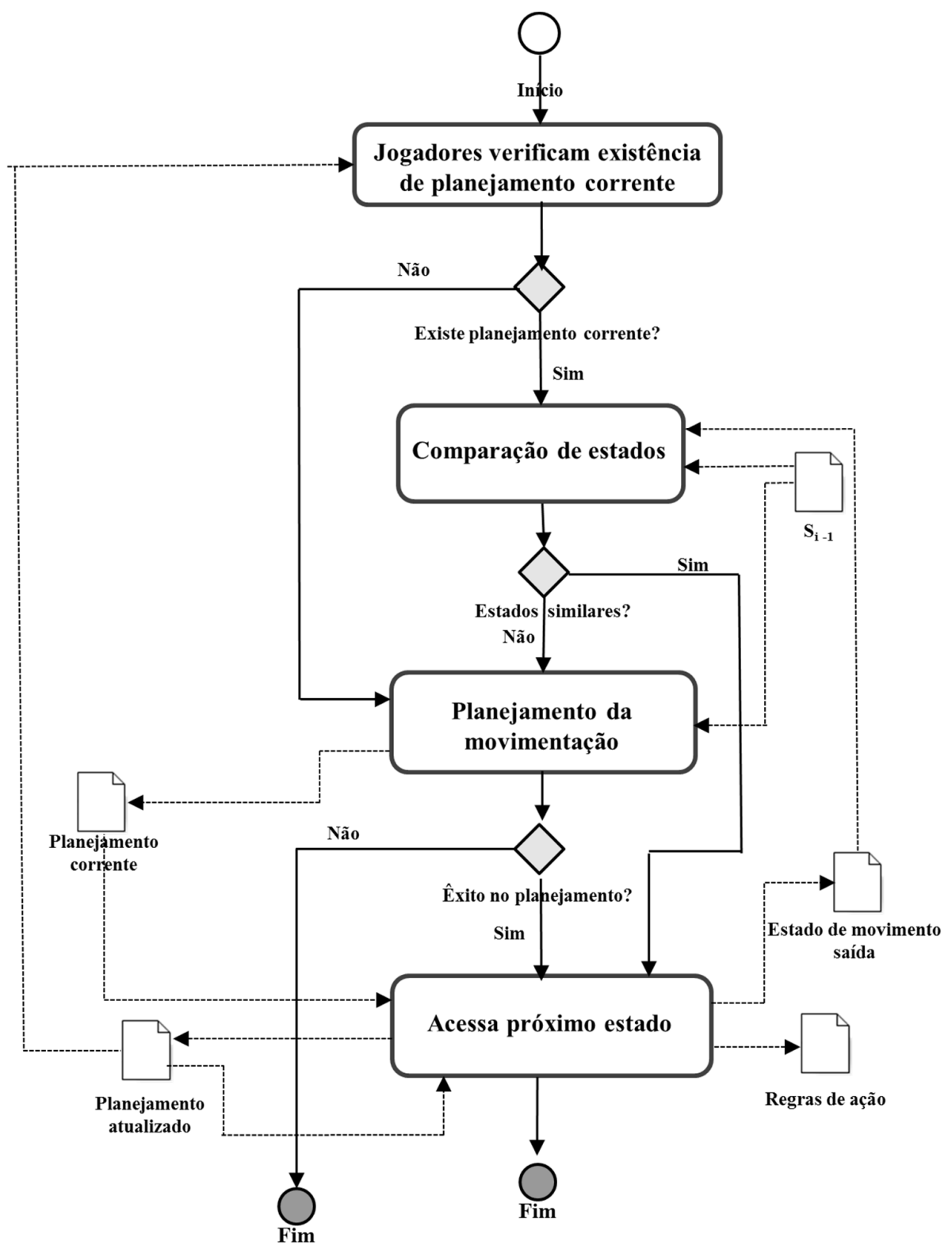

Figura 26: Planejamento da cooperação da equipe: fluxos de controle e de dados, nos quais: Si-1: estado atual do jogo. 


\subsubsection{Comparação de estados}

O processo "Comparação de estados" verifica a similaridade entre o estado de movimento-saída do último estado gerado pelo jogo, $\mathrm{S}_{\mathrm{i}-1}$, e o estado de movimentosaída do último estado planejado para ser executado (Figura 27). A comparação é feita entre os estados de movimento-saída pois interessa saber se há similaridade entre os objetivos alcançados na oposição em comparação com os que haviam sido planejados, o que é fornecido, respectivamente, pelo estado de movimento saída do estado do jogo e da estratégia.

Este processo é representado sequencialmente. Primeiro ocorre o entendimento do contexto pelos jogadores, indicado por "Jogadores interpretam estado do jogo", que recebe como entrada o dado- $\mathrm{S}_{\mathrm{i}-1}$. A partir dessa interpretação ocorre a comparação entre o estado de movimento do jogo e da estratégia no "Jogadores comparam estado real e planejado", tendo como entrada dado-estado-de-movimento-real e dado-estado-demovimento-planejado. A saída desse processo é o sinal que indica similaridade ou não entre os estados. Similaridade significa possibilidade de dar continuidade à movimentação que vinha sendo realizada. Já diferenças entre os estados indica necessidade de replanejamento da movimentação.

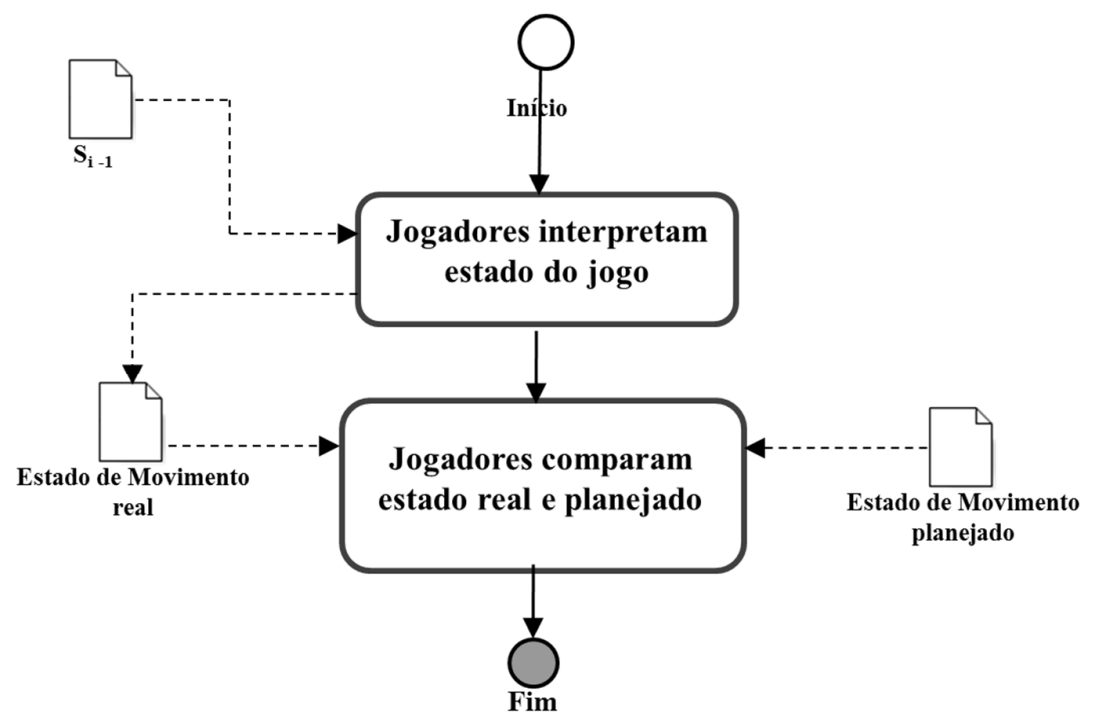

Figura 27: Comparação de estados: processos e fluxos de controle e de dados, nos quais:

Si-1: estado atual do jogo. 


\subsubsection{Planejamento da movimentação}

Nas situações em que uma nova movimentação deve ser elaborada (i.e., ausência de planejamento corrente ou ausência de similaridade enre estado do jogo e da estratégia), a primeira verificação a ser feita é a fase do jogo (Figura 15) em que a equipe se encontra (Figura 28). Esta informação é contida nos parâmetros do estado presente, dado- $\mathrm{S}_{\mathrm{i}-1}$, que é entrada do processo "Jogadores verificam fase do jogo". A constatação da fase é então testada em duas etapas. Primeiro se a posse de bola está determinada. Se a posse não é determinada, a fase é disputa ofensiva ou disputa defensiva. Se a posse é determinada, a fase é ataque ou defesa. Novo teste discrimina entre os dois possíveis tipos de disputa ou entre ataque e defesa. Com a fase definida, o próximo processo indica o momento em que os jogadores extraem da SC-ESTjogo, as especificações correspondentes à fase em que se encontram. Para tanto, nos processos "Extrai estratégia disputa ofensiva" e "Extrai estratégia disputa defensiva", há entrada do dado-SC-ESTjogo e saída, respectivamente, de dado-SC-ESTjogo-disputa-ofensiva e dado-SC-ESTjogo-disputa-defensiva. O dado da estratégia para a fase do jogo identificada é a entrada do processo subsequente, "Jogadores definem posicionamento", no qual uma das opções de estados estratégicos da fase de disputa será selecionada. A estratégia das fases de disputa é caracterizada por estados não conectados, ou seja, não há sequências, apenas nós isolados, pois a extensão sequencial do planejamento desta fase limita-se ao posicionamento especificado em um único estado.

No primeiro teste do processo, caso a posse de bola seja determinada, isso significa que a fase do jogo é ataque ou defesa. De forma semelhante ao ocorrido com as disputas, distingue-se entre ataque ou defesa (teste Booleano “Ataque?”) e então, o fluxo é direcionado para o processo "Extrai estratégia ataque" ou "Extrai estratégia defesa". Cada um deles recebe como entrada o dado-SC-ESTjogo e devolve na saída o dado-SC-ESTjogo-Ataque ou dado-SC-ESTjogo-Defesa.

$\mathrm{Na}$ sequência, o processo "Jogadores comparam estado real com estados de decisão e organizadores" indica a comparação feita pelos jogadores do estado resultante das interações no jogo com os estados de decisão e organizadores contidos no subconjunto da estratégia para aquele jogo e para a fase em que a equipe se encontra. 
O resultado da testagem da similaridade é verificado no teste Booleano "Possui similaridade?". Em caso negativo o fluxo termina, indicando que, na sequência, o jogo prossegue sem planejamento (i.e., pela tática) até que nova similaridade seja identificada. Caso contrário, o refinamento da busca de similaridade pelos jogadores é demonstrado com o teste "Similaridade com estado de decisão?". Havendo similaridade, o fluxo é direcionado para o processo "Jogadores selecionam sequência a partir do estado de decisão", o que significa que, na sequência, será escolhido um dos caminhos originado no estado de decisão identificado como mais próximo ao estado do jogo. De forma alternativa, não havendo nenhum estado de decisão semelhante, o fluxo é direcionado para "Jogadores selecionam sequência a partir de estado organizador". Este caminho leva a equipe a uma re-estruturação mais ampla, partindo de um dos estados organizadores da estratégia. Através de uma dessas maneiras, a sequência seguinte é definida.

A representação do fluxo que leva à testagem da similaridade entre o estado do jogo e o estratégico descreve uma economia na busca pois os testes Booleanos restringem a procura para o conteúdo da fase e depois, dentre todos os nós de uma fase, a busca ocorre apenas por nós específicos, organizadores e de decisão, que representam um sub-conjunto pequenos dos nós da fase. Além disso, um único caminho do fluxo é acionado de cada vez, conforme direcionamento a partir da resposta a cada teste Booleano. Com isso, cada dado de entrada dos processos torna-se ativo apenas quando há um fluxo de controle passando pelo respectivo processo. Da mesma forma, embora haja três términos possíveis para o processo, estes ocorrem alternadamente, conforme o caminho de cada iterada do fluxo. 


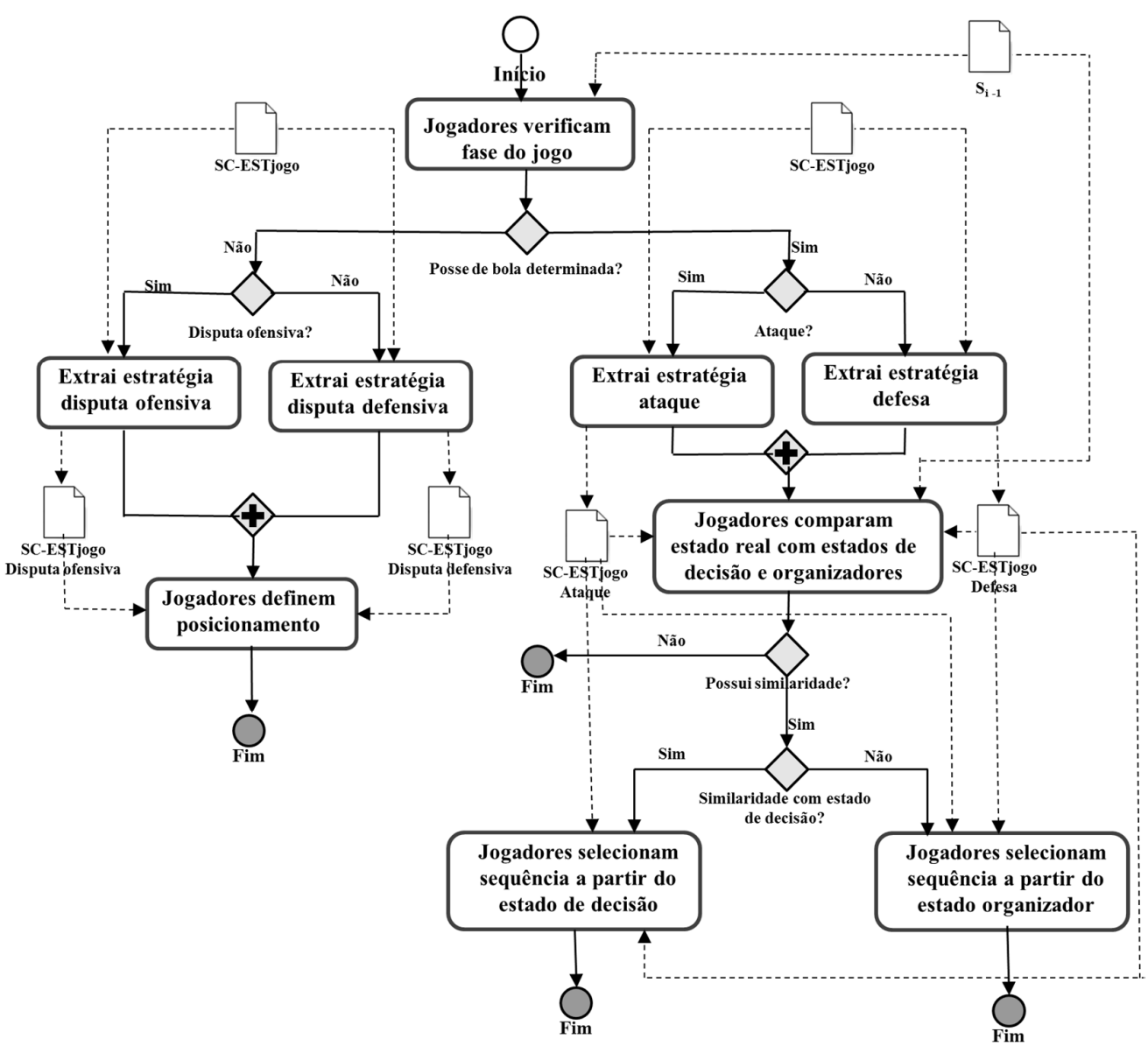

Figura 28: Planejamento da movimentação: processos e fluxos de controle e de dados, nos quais: Si-1: estado atual do jogo; SC-ESTjogo: sub-conjunto da estratégia para o jogo.

\subsubsection{Acesso ao próximo estado}

Definida a movimentação a ser executada, a etapa lógica subsequente é acessar o próximo estado (Figura 29). O entendimento dos jogadores quanto ao que devem fazer é representado pelo processo "Jogadores acessam estado subsequente da movimentação". Este processo tem como entrada o dado-Planejamento-corrente. Uma vez compreendido o que fazer, a saída é representada pelo dado-Planejamento-atualizado, no qual já não consta o estado a ser executado. A sequência do fluxo descreve a possibilidade de nem todos os jogadores compreenderem o que deve ser feito na sequência, com o teste 
“Jogadores compreendem especificação do estado?". Se há divergência entre os jogadores e a organização mínima necessária para a continuação da movimentação não é atingida, então o fluxo é encerrado e a oposição prossegue através do tático. Por outro lado, quando há compreensão do que deve ser feito na sequência, os jogadores realizam duas outras atividades, representadas pelos processos "Jogadores acessam regras de ação do estado" e "Jogadores acessam objetivo do estado". Dessa forma, eles compreendem tanto o que devem fazer individualmente, assim como o propósito coletivo das regras de ação especificadas, o que contribui para que a atuação aconteça de maneira coletiva. Na saída desses dois processos são gerados o dado-regras-de-ação, utilizado na execução da oposição, e o dado-estado-de-movimento-saída, utilizado na comparação realizada na próxima iterada do fluxo entre o que foi planejado (estado de movimento saída) e o que consumou-se com a oposição, o estado de movimento saída correspondente ao estado gerado no jogo.

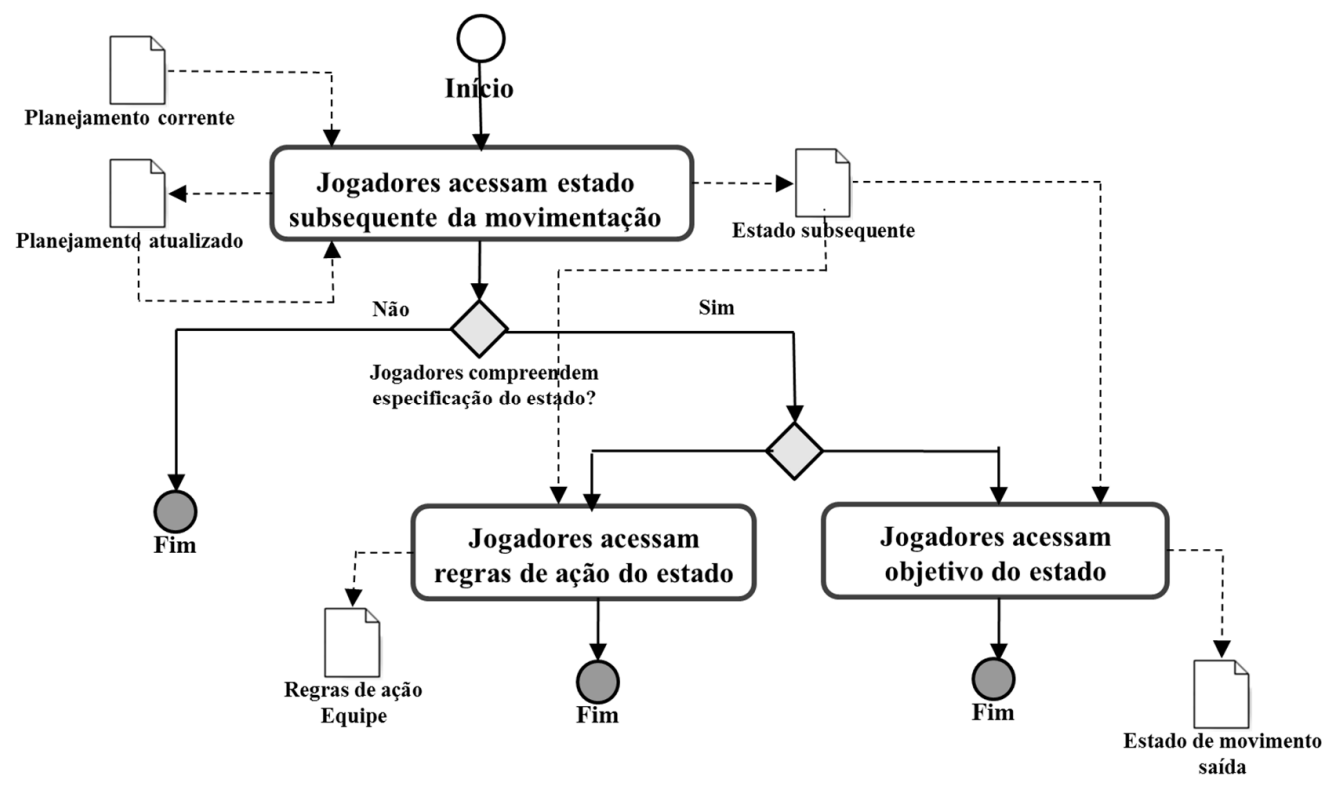

Figura 29: Acesso ao próximo estado: processos e fluxos de controle e de dados. 


\subsubsection{Oposição}

No processo "Oposição" é representado o momento no qual cada uma das equipes deve aplicar as regras de ação (Figura 30). Para isso, as regras de ação são especificadas para cada jogador. Este procedimento é representado pela entrada do dado-regras-de-ação-Equipe e saída da regra de ação destinada a cada jogador, dadoregra-J1 a dado-regra-Jn.

Os dados de regras de ação individuais são entrada de cada um dos processos “Jogador - Execução motora", que representa a aplicação da regra de ação através da execução da ação especificada. A saída desses processos é a representação da ação executada por cada jogador, o dado-Habilidade-motora-jogador.

A execução das habilidades motoras por cada jogador é a entrada do processo “Oposição gera novo estado", que produz o novo estado do jogo, dad- $\mathrm{S}_{\mathrm{i}}$, a partir das interações na oposição resultantes das habilidaes motoras executadas. $\mathrm{Na}$ iterada seguinte do fluxo, este dado será entrada de diversos processos, conforme demonstrado nos fluxos anteriores, com a denominação $S_{\mathrm{i}-1}$, pois passará a ser utilizado para geração do novo estado presente ao final do ciclo. 


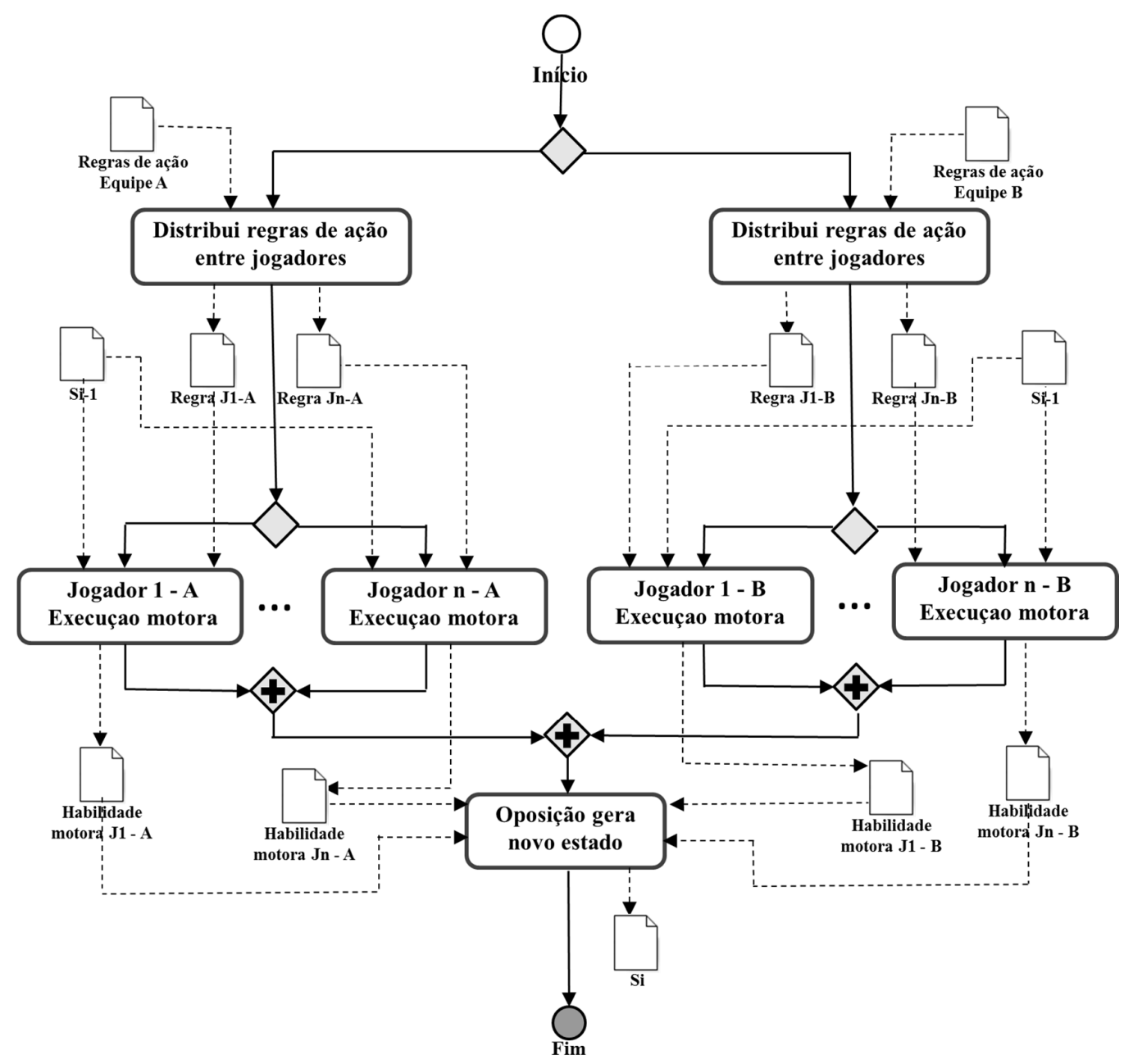

Figura 30: Oposição: processos e fluxos de controle e de dados.

A decomposição dos processos do jogo (Figuras 25 a 30) teve por objetivo modelar a maneira pela qual o planejamento da cooperação é gerado e executado no jogo em uma perspectiva coletiva. Na sequência será apresentada a modelagem da decisão de um único jogador, a maneira pela qual as informações contextuais são percebidas e processadas, uma regra de ação é selecionada e aplicada e, finalmente, uma habilidade de movimento básico é executada. 


\subsubsection{O jogador}

O processo de seleção de uma regra de ação, aplicação e execução da ação correspondente é apresentado na Figura 31a. Este processo é modelado por três processadores dispostos em sequência: o processador de alto nível, que recebe a informação global do ambiente (i.e., informação sobre os jogadores em todo o campo de jogo), seleciona uma regra de ação e a aplica para obter a habilidade esportiva a ser executada já decomposta na respectiva lista de regras de ação de baixo nível (i.e., as regras que controlam a execução das habilidades de movimentos básicos); o processador de baixo nível, que recebe informação local do ambiente (i.e., informação sobre os jogadores na região do campo de jogo próximo ao próprio jogador em questão), a lista de regras de ação de baixo nível a ser aplicada, seleciona uma regra de ação e a aplica para obter a habilidade de movimento básico a ser executado; o processador da execução motora, que recebe a habilidade de movimento básico a ser executado e o executa.

Figuras $32 a$ e $32 b$ exemplificam o processo para selecionar e aplicar uma regra de ação, que leva à execução de uma ação no jogo. Este processo tem início instantes antes da execução da ação quando o jogador percebe um evento, a partir de alguma mudança contextual, que dispara sua percepção. A percepção será acessada para a seleção de uma nova regra de ação (i.e., deslocamentos e gestos esportivos de outros jogadores e deslocamento da bola) pois o evento percebido irá requerer a modificação do seu comportamento em um futuro próximo. A percepção iniciada instantes antes da ação até o momento presente caracteriza a informação global do jogo (Figura 32). No módulo de percepção de alto nível (círculo cinza do processador de alto nível, nas Figuras 32a-b), esta informação associada ao conhecimento a priori dos demais jogadores (e.g., repertório técnico, capacidade de decisão e especificações estratégicas dos demais jogadores) suporta a interpretação semântica do contexto do passado recente e do futuro próximo predito. Além disso, o jogador aprendeu, a partir da especificação da estratégia da equipe, uma sequência ordenada de regras de ação estratégicas (Ações 1 a $k$ ) e possui outra sequência ordenada de regras de ação táticas viabilizadas pelas suas experiências prévias no esporte (Opções 1 a $m$ ). A lista completa de regras de ação disponíveis é composta pelo conjunto das listas de regras de ação estratégicas e táticas 
(Regras de Ação (Ações)). A interpretação do contexto semântico e a lista de regras de ação de alto nível são as informações de entrada para o módulo de decisão de alto nível (círculo preto).

Um exemplo do processamento do modulo de percepção é apresentado nas Figuras 31 $a-b$. Na equipe atacante, há uma regra estratégica de alto nível que especifica o passe dos jogadores 1 ou 3 para o 5 . Uma vez que o passe é realizado, outra regra especifica que o passador deve realizer um corta-luz para o outro jogador sem bola se, baseado na interpretação semântica do contexto futuro, o jogador que realizou o passe avalia que o corta-luz resultará em uma boa oportunidade de finalização. Então, a seleção da segunda regra de ação considerou que a bola estava com 5 , mas também requer informação prévia sobre o jogador que realizou o passe e sua interpretação semântica do futuro próximo predito. Note que o evento disparador do início da interpretação semântica do context da segunda regra de ação foi o passe para 5 .

a)

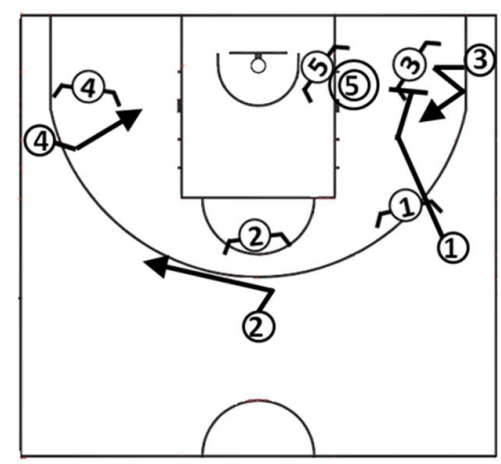

b)

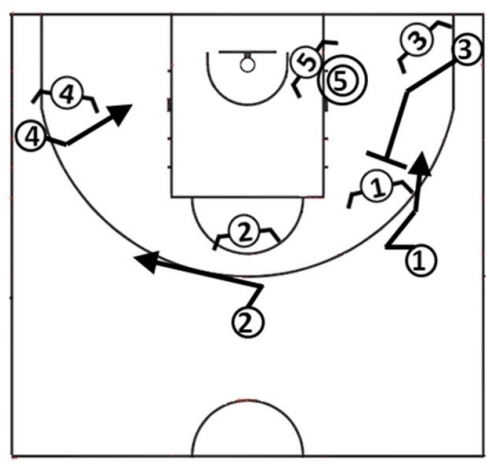

Figura 31: Regra de ação estratégica de alto nível que especifica a execução de um corta-luz. Em 31a, o passe prévio para 5 foi realizado por 1. Em 31b, o passe prévio para 5 foi realizado por 3 .

Dando sequência ao entendimento da Figura 32, o módulo de decisão seleciona a primeira regra de ação cuja condição de entrada seja compatível com a interpretação do contexto realizada. A saída é uma habilidade esportiva, decomposta em suas habilidades de movimentos básicos constitutivas.

A aplicação da regra de ação é controlada pelo processador de baixo nível, que também tem módulos de percepção e decisão (círculos cinza e preto, respectivamente). 
Este processo começa instantes antes quando o jogador percebe algumas modificações no ambiente local (i.e., o término da última habilidade de movimento básico executada ou alguma outra modificação local no ambiente) que requeiram a subsequente seleção de uma nova habilidade de movimento básico. A percepção deste instante até o momento presente caracteriza a informação local do jogo (Figura 32a-b). Esta informação suporta a interpretação semântica do contexto local do passado recente e do future próximo predito.

O módulo de decisão de baixo nível também seleciona uma regra de ação de uma lista. A primeira regra da lista controla a execução da habilidade de movimento básico originalmente planejado e as outras regras controlam os possíveis ajustes associados a ele. A habilidade de movimento básico planejado é a primeira alternativa porque foi o especificado pela decomposição da habilidade esportiva. A interpretação do contexto e uma lista de regras de ação são as informações de entrada para o módulo de decisão de baixo nível (círculo preto). O módulo de decisão seleciona a primeira regra de ação da lista, cuja condição de entrada seja compatível com ainterpretação local do contexto. No processador da execução motora, ocorre a execução motora da habilidade de movimento básico selecionada.

Durante a execução da habilidade de movimento básico planejado, há um sinal de controle que retroalimenta o módulo de percepção de alto nível, sendo emitido em intervalos de tempo muito inferiores que a duração da execução do movimento. Este sinal leva à re-execução do processo de controle (i.e., um processo de alto nível seguido de um processo de baixo nível). $\mathrm{Na}$ execução deste processo há três alternativas. Primeira, a habilidade esportiva selecionada e a imediata habilidade de movimento básico resultante de sua decomposição são confirmados, então o movimento continua sendo executado. Segunda, a habilidade esportiva selecionada é confirmada, mas a habilidade de movimento básico não é, porque deve ser ajustado ou teve sua execução completada. Se o movimento deve ser ajustado, uma regra de ação alternativa levará à execução de uma opção (i.e., um movimento alternativo). No caso do movimento planejado ter sido finalizado, uma nova lista de regras de ação deve ser criada para controlar a execução do próximo movimento. Terceira, há a seleção de uma nova habilidade esportiva porque a anterior acabou ou foi interrompida em decorrência de 
mudanças no contexto. Então, uma nova habilidade esportiva é selecionada e uma lista de regras de ação de baixo nível correspondente é criada.

Há um atraso para o sistema tomar uma decisão. Este é o intervalo de tempo correspondente à adição da duração do sinal de feedback e do tempo total de processamento dos módulos de percepção e decisão de alto e baixo níveis. O sistema não é capaz de regair adequadamente em duas circunstâncias. Primeira, se o tempo requerido para a reação é menor que o intervalo de tempo necessário para o sistema tomar uma decisão. Segunda, se osistema não possui uma regra de ação apropriada para reagir a uma dada situação do jogo.

Na Figura 32a, é observado que a habilidade esportiva foi selecionada, decomposta em suas habilidades de movimentos básicos e a primeira delas está sendo executado. Na Figura 32b, a habilidade de movimento básico continua sendo realizada, pela execução da segunda habilidade de sua sequência. 


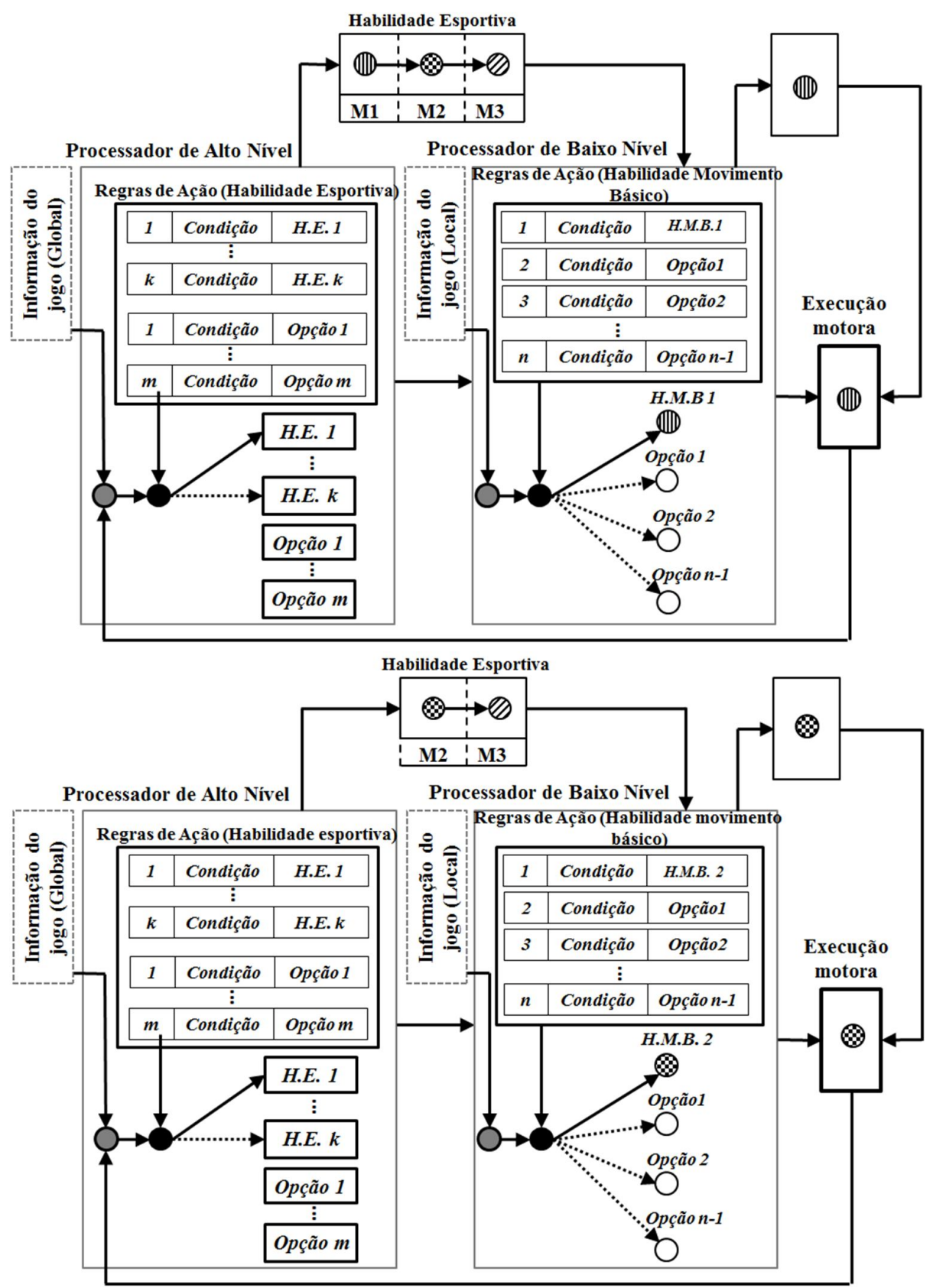

Figura 32: Modelo da seleção de um gesto esportivo e execução da sua sequência de primitivas por um jogador. 32a): execução da primeira habilidade de movimento básico, 32b): execução da segunda habilidade de movimento básico. No qual: $\mathrm{O}$ - Percepção; - Decisão.

H.E.: Habilidade esportiva; H.M.B.: Habilidade motora básica. 
A modelagem do jogador apresentada descreve o nível mais fundamental de gerenciamento da informação do SC-ESTjogo pela equipe, através da utilização de regras de ação, que conforme formalizado no capítulo anterior, são os elementos lógicos fundamentais em uma estratégia.

\subsubsection{Discussão}

O estudo apresentado neste capítulo possui dois resultados principais. O primeiro deles é a formalização da integração entre a estratégia e a dinâmica da oposição entre as equipes em um jogo. O segundo é a decomposição da oposição em níveis hierárquicos integrados, do mais genérico para o mais específico, definindo suas propriedades dinâmicas fundamentais. Estudos que abordaram aspectos do fenômeno anteriormente, investigaram, de forma intuitiva, algumas noções de controle do planejamento das ações (LEBED, 2007), ou ainda formalizaram alguns aspectos da dinâmica entre fases do jogo (PERSE et al., 2009). No entanto, a abrangência da representação da dinâmica do jogo descrita neste estudo até onde nos foi dado conhecer não encontra paralelo na literatura. São originais tanto a abordagem de modelagem utilizada quanto a definição da integração da estratégia com a dinâmica do jogo e os níveis de processos da oposição delimitados.

No modelo proposto, a dinâmica da oposição contempla distintas instâncias de decisão, cuja estrutura hierárquica foi modelada. No mais alto nível de generalização, a comissão técnica define o SC-ESTjogo, ou seja, as especificações estratégicas a serem empregadas no jogo. O SC-ESTjogo é a entrada de dados que orienta as ações de cada equipe durante a oposição, sendo modelado como um sistema dinâmico discreto. Sua representação segue o formalismo do $\mathrm{EST}_{\mathrm{M}}$ (descrito na seção 3.1). Portanto, contém especificações para todas as fases da oposição. Para cada intervalo entre duas interrupções subsequentes do jogo a comissão técnica pode selecionar um novo subsistema do SC-ESTjogo.

A utilização do sub-sistema do SC-ESTjogo é feita pelos jogadores a cada mudança de fase do jogo (i.e., ataque, defesa, disputa ofensiva, disputa defensiva) pois 
nesses momentos é feita uma escolha quanto à movimentação a ser utilizada, a partir das opções disponíveis no SC-ESTjogo e das circunstâncias da oposição. A duração de uma movimentação corresponde à sequência de estados de uma dada sequência do subsistema do SC-ESTjogo entre dois estados de decisão ou organizadores. Ao término de um intervalo como esse, nova decisão deve ser tomadapara que outra sequência de estados seja escolhida e a correpondente movimentação realizada. Para realizar a escolha da sequência subsequente os jogadores acessam: i) os dados do SC-ESTjogo, ii) dado do estado real do jogo produzido na oposição (i.e., dinâmicas dos jogadores), iii) metadado contendo demais informações como o aproveitamento da equipe em determinada movimentação, o tempo restante de jogo, a diferença no placar, etc.

A decisão coletiva pela escolha de uma dentre diversas movimentações subsequentes possíveis pode ocorrer de diferentes maneiras. Uma delas é modelada pelo jogador com bola como sendo o agente decisor. Dessa forma, para a equipe atacante é o jogador com a bola quem escolhe o próximo estado e os demais jogadores seguem sua decisão. Para a equipe defensora, de maneira análoga, o defensor do jogador com bola escolhe o estado seguinte e os demais defensores seguem sua decisão. Outras estruturas de decisão coletiva podem existir e devem constituir objeto de estudo para o aperfeiçoamento futuro da modelagem realizada.

Definida a movimentação, para executar o estado eminente os jogadores podem optar pela regra de ação especificada no estado ou por uma regra alternativa, caso haja necessidade de realizar algum ajuste às restrições impostas pelo adversário. A execução das regras de ação induz à constituição das UESTs e à orquestração entre elas, constituindo a ação coletiva da equipe. Uma vez concluída a ação coletiva no estado, novo processo de decisão coletivo levará à execução do estado seguinte. Caso haja convergência entre os jogadores na identificação coletiva do estado subsequente, a equipe segue atuando a partir da orientação estratégica. Caso contrário, seguirá jogando a partir da tática até que consiga se organizar com uma nova movimentação coletiva, prevista no SC-ESTjogo.

Após um período da oposição no qual as ações são táticas, a reorganização coletiva da equipe pela estratégia decorre da identificação de um estado de decisão ou organizador. Esses estados são possíveis pontos de retorno a uma atuação orientada pela estratégia pois suas especificações tem características que permitem iniciar uma nova 
movimentação a partir deles. Nesses estados há diversidade de sequência subsequentes possíveis, o que permite melhores ajustes ao contexto que se apresenta. Seu reconhecimento é facilitado pelo fato de serem em número reduzido frente ao total de estados da estratégia. Em circunstâncias nas quais a equipe se encontra atuando a partir da estratégia, os objetivos são pontuar, proteger a própria meta ou recuperar a bola, quando se encontra, respectivamente, na fase ofensiva, defensiva ou de disputa. Já quando atua apartir da tática, verificam-se os mesmos objetivos acrescidos de mais um, voltar a atuar conforme a própria estratégia.

Nos momentos em que a equipe segue as especificações previstas na estratégia, a probabilidade da escolha de cada uma das sequências de estados possíveis é adaptativa, ou seja, as probabilidades são modificadas a cada ciclo de percorrimento do sistema (i.e., cada interação da oposição). A modificação das probabilidades é consequência do resultado da oposição nas interações anteriores, isto é, o grau de êxito nas execuções pregressas de sequências de estados escolhidas. A informação da história pregressa da oposição é armazenada no metadado e na memória dos jogadores e será utilizada no novo cálculo de probabilidades de percorrimento das sequências de estados da estratégia. Portanto, na definição da SC-ESTjogo a comissão técnica atribui probabilidades iniciais de ocorrência das sequências de estados conforme a expectativa de uso frente ao adversário que será enfrentado. Então, ao longo do jogo estas probabilidades podem ser alteradas, em função das expectativas que se confirmam ou não. Em um exemplo, supondo que, ofensivamente, uma equipe de basquetebol tenha três possibilidades de jogadas e, ao executar uma delas não encontre dificuldades para vencer a oposição, nas próximas posses de bola aumentará a chance de uma nova ocorrência da mesma jogada. Por outro lado, caso a jogada selecionada não seja bemsucedida, sua chance de ocorrência diminuirá. Uma abordagem matemática possível para modelar esse problema é a inferência Bayesiana (BOLSTAD, 2007), que trata da probabilidade condicional de ocorrência de um evento.

Uma vez que o planejamento tenha sido estabelecido, cada jogador executa sua respectiva regra de ação planejada, sendo o resultado da interação com o adversário a geração de um novo estado do jogo (i.e., Si-real). Conforme representado no modelo do jogador (Figura 32), a execução da regra de ação é realizada em dois níveis (i.e., processadores de alto e baixo nível). Em ambos é possível seguir exatamente a 
especificação estratégica ou promover ajustes que viabilizem a ação do jogador. A organização do modelo em alto e baixo nível implica uma hierarquia de decisão, do mais geral (habilidade esportiva) para o mais detalhado (habilidades de movimentos básicos constituintes da habilidade esportiva). Outras instâncias de decisão, de nível hierárquico superior, que explicam a maneira pela qual um jogador planeja a sequência de estados a ser executada, não foram descritos mas são condição para que o jogador siga o planejamento da equipe ao longo de múltiplos estados.

Após o término do planejamento, a interação dos jogadores de ambas equipes é modelado como um sistema dinâmico contínuo. Os estados são produzidos constantemente e comparados com os estados existentes no SC-ESTjogo, nos momentos de consulta da estratégia (indicado pelo sinal de feedback da Figura 22). Quando não há diferenças significativas entre o estado do jogo e os estados da SC-ESTjogo, um novo estado do SC-ESTjogo é selecionado. Por outro lado, quando há diferenças, uma nova movimentação deve ser selecionada.

Decorre da modelagem das instâncias de decisão na dinâmica do jogo dois objetos de estudo imediatos. O primeiro refere-se ao aprofundamento da modelagem da decisão coletiva, pois é possível que, em certas circunstâncias, outros jogadores além do jogador com bola atuem como agentes decisórios na transição entre estados. Porém, as propriedades formais dessas situações não se encontram esclarecidas. O segundo referese à investigação da relação entre a duração da atuação da equipe de acordo com suas especificações estratégicas e seu êxito, pela maior possibilidade de orquestração coletiva de suas ações, quando comparado à atuação apenas pela tática, sem um referencial estratégico coletivo.A capacidade de uma equipe lidar com as restrições impostas pelo adversário e permanecer seguindo as especificações da própria estratégia durante a oposição difere entre ECIs de campo grande (i.e., elevada proporção da área, em metros quadrados, por jogador no campo de jogo) e de campo pequeno. São exemplos de ECIs de campo grande e pequeno, respectivamente, o futebol e o basquetebol. A estrutura de controle dos esportes de campo grande possui um nível adicional de decomposição. Além dos níveis do jogador e das UESTs, estas ainda são alocadas em setores do campo (i.e., UESTs ofensivas e UESTs defensivas), para então o nível coletivo ser organizado. Em comparação, no basquetebol todos os jogadores atacam e defendem. Além disso, devido à densidade de ocupação dos espaços, em ECIs 
de campo grande, o planejamento dos estados especifica regiões maiores a serem ocupadas por cada jogador em cada estado. Essas características aumentam a chance de ruídos na orquestração da equipe. Como consequência, em ECIs disputados em campo grande parece haver mais momentos da oposição em que a equipe precisa atuar taticamente, quando comparados aos de campo pequeno. Verifica-se maior imprevisibilidade nos resultados da oposição e uma maior quantidade de ajustes táticos para que a equipe atue coletivamente, já que não é possível especificar com precisão a movimentação coletiva.

A elaboração teórica sobre as diferenças de orquestração entre ECIs de campo grande e de campo pequeno, decorrentes da modelagem da dinâmica do jogo, pode dar suporte ao entendimento de questões que até então haviam sido formuladas de maneira imprecisa, tal como o número diferente de níveis de controle entre deles. O menor número de níveis dos ECIs de campo pequeno parece ter permitido, ao longo do tempo, maior detalhamento das possibilidades de elaboração e ensino da estratégia. Em livros didáticos sobre estratégia nesses esportes verifica-se, por exemplo, maior diversidade das especificações de estratégias de basquetebol quando comparadas às do futebol. Entretanto, em uma perspectiva científica verifica-se a possibilidade de amplo desenvolvimento das metodologias de desenho e ensino de estratégias para esportes de campo grande. A teoria da estratégia desenvolvida no capítulo 3.1 (i.e., o $\mathrm{EST}_{\mathrm{M}}$ ) demonstra que é possível desenhar estratégias completas para ambos os tipos de esporte, sendo o desenho mais complicado para esportes de campo grande, dada a necessidade de mais especificações para estruturar a orquestração. Porém, a dinâmica da oposição modelada indica os momentos nos quais a orquestração coletiva é efetivada e com isso direciona também o desenho da estratégia, contribuindo para aperfeiçoar sua elaboração para esportes de campo grande.

Dessa forma, a modelagem da dinâmica da oposição e da estratégia se complementam, pois define os momentos nos quais a informação estratégica é utilizada pelos jogadores. Em uma perspectiva genérica para todos os ECIs, indicam a relação entre planejamento e execução das ações nos ECIs, o que consiste uma contribuição inédita com diversos aprofundamentos possíveis. 
3.3 Classificação das dinâmicas ofensivas e defensivas no basquetebol

A principal contribuição da pesquisa descrita neste capítulo é uma metodologia de classificação dos comportamentos possíveis em um ECI, sendo composta por duas etapas principais. Primeiro, a validação das classes de comportamentos ofensivos e defensivos do jogo, constituídas por um conjunto limitado de dinâmicas individuais, grupais e coletivas, das quais um estrategista pode fazer uso para elaborar a estratégia da sua equipe. Segundo, a modelagem das possíveis interações ataque versus defesa a partir das classes de dinâmicas definidas e seus possíveis resultados. Para tanto, na subseção 3.3.1 serão apresentadas as etapas do procedimento de validação das classes de dinâmicas. Na sub-seção 3.3.1.1 as classes formuladas são apresentadas. Na sub-seção 3.3.1.2 é apresentada maneira pela qual a reprodutibilidade dos critérios que definem cada classe foram testados. Na sub-seção 3.3.1.3 é explicado como as classes definidas foram empregadas na análise de jogos de basquetebol. Na sub-seção 3.3.1.4 são apresentadas as amostras utilizadas e os procedimentos para coleta de dados. Na subseção 3.3.2 são apresentados os procedimentos estatísticos empregados. Na sub-seção 3.3.3 são apresentados os resultados, ao longo das seguintes sub-seções: i) na 3.3.3.1 são apresentadas as classes de dinâmicas restantes após o processo de validação; ii) na 3.3.3.2 são apresentados os coeficientes dos testes de reprodutibilidade; iii) na 3.3.3.3 são apresentados os resultados da análise de jogos de basquetebol a partir das dinâmicas validadas. Finalmente, na sub-seção 3.3.4 as principais contribuições deste capítulo são discutidas. Os procedimentos experimentais utilizados no presente capítulo foram aprovados pelo Comitê de Ética em Pesquisa (CEP) da Escola de Educação Física e Esporte da Universidade de São Paulo (Protocolo 2009-10).

\subsubsection{Métodos}

A validação das classes de dinâmicas de criação de espaço e dinâmicas de proteção de espaço foi separada em quatro etapas: a) elaboração das classes, b) apreciação por especialistas para correções conceituais e técnicas, c) análise dos critérios definidores das classes, a partir dos coeficientes de reprodutibilidade obtidos 
por especialistas, na identificação das classes observadas durante ações ofensivas e defensivas em jogos, d) utilização do instrumento para a análise de jogos de basquetebol (FONSECA, SALLES \& PARENTE, 2008). Nas etapas a), b), c) foi feito um esforço experimental para a realização de uma abordagem exaustiva quanto às possibilidades de comportamentos ofensivos e defensivos no jogo, implicando grande diversidade de jogos analisados para suportar as representações propostas. Na etapa d), a partir das classes de comportamento validadas, procurou-se depreender sua possibilidade de informar sobre as preferências táticas das equipes.

\subsubsection{Formulação das classes de dinâmicas}

Dinâmica de criação de espaço (DCE) e dinâmica de proteção de espaço (DPE) são definidas como comportamentos ofensivos e defensivos, que têm como objetivo, respectivamente, criar espaço no setor defensivo adversário, proporcionando condições para que ocorra uma finalização ou uma ocupação do espaço de maneira a impedir que uma finalização ocorra e ensejando a recuperação da posse da bola.

Uma versão preliminar da classificação de DCEs e DPEs foi desenvolvida a partir da revisão da literatura (KRAUSE \& PIM, 2002; SMITH \& SPEAR, 1981; WINTER, 1962; WOODEN, 1966), análise de diversos jogos e discussões com treinadores de basquetebol com experiência internacional. Para estruturar a classificação foram considerados três critérios: i) o número de jogadores envolvidos, que representa uma medida objetiva da coordenação inter-pessoal; ii) o tipo de habilidade esportiva empregada, que descreve a solução motora selecionada frente a um determinado contexto; iii) o contexto de decisão, que indica a presença ou ausência de coordenação coletiva definida a priori para então ocorrer a ação de criação ou proteção de espaço.

A partir da definição preliminar de 13 e 15 classes, respectivamente de DCEs e DPEs, foram analisados 35 jogos internacionais (2625 posses de bola), a partir dos quais foram constituídas duas amostras aleatórias de 105 ações cada, representativas das classes propostas. O total das ações foi distribuído entre as classes concebidas e organizadas em um vídeo. Algumas das classes apresentaram padrão altamente estereotipado, enquanto outras eram mais heterogêneas. Por este motivo, as mais heterogêneas tiveram uma recorrência maior nas amostras de maneira a contemplar 
todas as nuances identificadas. A frequência mínima de uma classe na amostra foi de três ações. Este vídeo foi apresentado a três treinadores profissionais, com mais de 15 anos de experiência, para análise da lógica e semântica das classes propostas. Cada treinador não teve acesso à análise dos demais até que todos tivessem realizado suas avaliações. Correções das classes foram realizadas baseando-se nos comentários dos especialistas. Somente DCEs e DPEs com coeficientes Kappa $\geq 0.85$ de concordância entre treinadores foram mantidas (JAMES, TAYLOR \& STANLEY, 2002).

Outra amostra foi constituída para a avaliação da reprodutibilidade da utilização dos critérios definidores das classes restantes após a apreciação dos treinadores. A paritr de 996 posses de bola referentes a 12 equipes analisadas em campeonatos internacionais, um pesquisador sorteou uma amostra de 85 posses de bola.

Finalmente, após a realização dos primeiros experimentos com as dinâmicas ofensivas, constatou-se que a informação quanto à direção de deslocamento na realização das DCEs poderia acrescentar uma informação relevante sobre a estratégia que orienta a ação. Por exemplo, se um corta-luz na lateral da quadra é orientado de tal forma que a obstrução da passagem do defensor favorece o deslocamento em direção ao fundo da quadra ou para o meio. Embora trata-se de uma constatação bastante objetiva também foi realizada a testagem da reprodutibilidade dos critérios dos avaliadores. Para isso, a mesma amostra de 85 posses de bola foi utilizada pois não foi identificado conflito no tipo de informação que seria extraída em cada uma das testagens de reprodutibilidade.

\subsubsection{Testagem da reprodutibilidade}

A reprodutibilidade intra e inter-observadores foi testada por outro grupo de três treinadores de basquetebol com experiência internacional. As posses de bola selecionadas foram organizadas, de forma aleatória, em um video contendo número semelhante de ações de cada classe de DCEs e DPEs definidas no estágio prévio do processo de validação. Então, os treinadores convidados a participar do experimento avaliaram as dinâmicas em cada posse de bola, sem conhecimento do resultado da análise de seus pares. A análise das dinâmicas foi feita em três ocasiões diferentes, com intervalo de uma semana entre elas, para eliminar efeito de memória das posses de bola 
analisadas. As posses de bola foram apresentadas em ordem aleatória, em cada ocasião, assim como entre ocasiões de análise. Os treinadores foram autorizados a assistir aos lances do video quantas vezes necessário, assim como fazer uso do recurso da câmera lenta, para aumentar a precisão do julgamento. Os índices de reprodutibilidade foram avaliados conforme sugerido por Landis (1977). Assim, considerou-se a avaliação do índice de concordância Kappa da seguinte maneira: 0 - sem concordância alguma, 0,01 a 0,20 - concordância mínima, 0,21 a 0,40 - concordância pequena, 0,41 a 0,60 concordância moderada, 0,61 a 0,80 - concordância substancial e 0,81 a 0,99 concordância quase perfeita.

\subsubsection{Aplicação à análise de jogos}

A aplicação de classes de equivalência de comportamentos ofensivos e defensivos que consistam nas possibilidades de especificações estratégicas de uma comissão técnica e, consequentemente, possam ser empregadas para a análise dos padrões táticos no jogo teve sua complexidade aumentada progressivamente, ao longo de três momentos de coleta e tratamento de dados, com amostra diferentes.

No primeiro momento foi feita uma análise das DCEs de equipes de alto nível, com o objetivo de compreender a extensão da contribuição destas classes de comportamentos para a caracterização do jogo ofensivo de equipes. No segundo momento, as DCEs foram empregadas no espectro completo de categorias competitivas do basquetebol de São Paulo para caracterizar possíveis diferenças no jogo das diferentes idades. No terceiro momento, DCEs e DPEs foram integradas para investigar os comportamentos de uma das equipes levando-se em conta também o comportamento da equipe adversária.

Em todos os momentos, a unidade amostral considerada nos jogos analisados é a posse de bola, definida como o período de jogo que se inicia quando uma equipe adquire o controle da bola e se encerra no momento em que a outra equipe recupera o controle da mesma. O reinício do jogo após uma falta no ato do arremesso foi considerado como uma nova posse de bola. Outros tipos de faltas, com reposição lateral ou do fundo da quadra, foram consideradas como continuação da mesma posse de bola. 
A análise da eficiência das dinâmicas em gerar situações de finalização e a associação das dinâmicas ao aproveitamento das finalizações foram estruturadas da seguinte maneira. No caso de lances-livres, os pontos foram referenciados à posse de bola encerrada com o ato da falta. Em caso de rebote ofensivo, tanto depois de um lance-livre ou de um arremesso com a bola em jogo, arremessos realizados logo após a captura do rebote não caracterizaram uma nova posse de bola. Entretanto, se um passe ocorreu depois do rebote ou o reboteador criou espaço antes de arremessar a bola, a ação foi considerada em uma nova posse de bola.

No jogo, a interação entre DCEs e DPEs pode gerar resultados bastante variados. O conjunto dos possíveis resultados da interação entre dinâmicas ofensivas e defensivas foi formalizado através da utilização de um modelo lógico da oposição no basquetebol. Para tanto, a linguagem adotada para representação foi a NMPN (ERIKSSON \& PENKER, 2000), já apresentada anteriormente na seção 3.2.2.1 deste documento, e cuja aplicação se justifica pois seu conjunto genérico de conceitos e possibilidades de modelagem tornam-na adequada para a especificação, em alto nível de abstração, de processos com naturezas distintas. A interpretação dos elementos gráficos da linguagem pode ser feita a partir da Figura 24 (seção 3.2.2.1).

\subsubsection{Amostra e coleta de dados}

A amostra e a coleta dos dados podem ser divididas em três subconjuntos, representativos do avanço do conhecimento sobre o objeto investigado.

Em um primeiro momento, apenas as DCEs foram empregadas na análise de jogos das equipes masculinas que se classificaram para as quartas-de-final dos Jogos Olímpicos de Pequim - 2008 (Estados Unidos (EUA), Espanha (ESP), Argentina (ARG), Lituania (LIT), Grécia (GRE), Croácia (CRO), Australia (AUS) e China (CHI)). Os jogos analisados e seus respectivos resultados foram os seguintes: fase de classificação: a) ARG 85 x 68 AUS; b) ARG 77 x 53 CRO; c) GRE 91 x 77 CHI; d) EUA 92 x 69 Gre; e) LIT 86 x 73 CRO; f) ESP 85 x 75 CHI; quartas-de-final: g) ARG 80 x 78 GRE; h) ESP 72 x 59 CRO; i) EUA 116 x 85 AUS; j) LIT 94 x 68 CHI; disputa de terceiro lugar: k) ARG 87 × 75 LIT; e final: 1) EUA 118 x 107 ESP. Foram analisadas 1902 posses de bola. A aquisição dos dados ocorreu por meio de anotação 
manual dos jogos, observados a partir de vídeos gravados de transmissões televisivas oficiais.

Em uma segunda aplicação das DCEs, estas foram empregadas para analisar equipes paulistas de categorias de base e adultas. Os participantes foram as equipes semifinalistas do campeonato paulista de basquetebol masculino - 2008, em todas as oito categorias etárias disputadas. A seguir são apresentados os nomes das categorias etárias, respectivas idades e número de jogos analisados: i) pré-mini (12 anos, 6 jogos), mini (13 anos, 6 jogos), mirim (14 anos, 6 jogos), infantil (15 anos, 5 jogos), infantojuvenil (16 anos, 8 jogos), cadete (17 anos, 5 jogos), juvenil (18 e 19 anos, 6 jogos), adulto (livre, 4 jogos). Até a categoria infantil, os jogos avaliados ocorreram no quadrangular final. Já nas categorias seguintes, os jogos avaliados ocorreram nos playoffs semifinal e final. No total, 7935 posses de bola foram analisadas. A aquisição dos dados ocorreu por meio de filmagem in locu dos jogos e posterior anotação manual dos eventos relevantes. Para a filmagem a câmera foi posicionada no centro da quadra, a pelo menos 5 metros do solo e com recuo suficiente para enquadrar as duas linhas laterais. Nesta coleta de dados houve uma evolução na direção de compreender a modulação do comportamento ofensivo pela defesa adversária pois foi considerado o tipo de defesa contra o qual se atacava (i.e., individual ou zona).

No terceiro momento de coleta de dados, foram analisadas as DPEs conjuntamente com as DCEs. A análise das DPEs permitiu a integração das dinâmicas ofensivas e defensivas e, consequentemente, foi possível analisar ambos comportamentos envolvidos na oposição. Esta progressão entre os momentos de coleta até atingir a análise da oposição foi planejada de maneira ao entendimento do fenômeno a partir do ataque direcionar a abordagem da defesa e, finalmente, da oposição. Neste momento em que o foco é a modulação do comportamento da equipe pelo adversário optou-se pela investigação de um número reduzido de equipes, em um contexto competitivo particular e favorável a este tipo de análise. Foram analisados seis jogos consecutivos da mesma equipe, Barcelona F.C., no campeonato espanhol, contra duas equipes diferentes, Caja Laboral e Bilbao Baskonia, em duas séries de melhor de três jogos, nos play-offs semi-final e final. Desta forma, pretendeu-se obter uma amostra consistente acerca de uma mesma orientação estratégica, que também poderia ser observada, de maneira consistente, em sua modulação contra duas estratégias distitntas 
entre si. O sistema de disputa em play-offs contribui para minimizar o problema do tamanho da amostra para análise dos comportamentos de uma equipe. Embora ainda assim possa constituir uma amostra pequena, frente à maneira como o fenômeno investigado ocorre, é uma das melhores opções possíveis. Desta forma, pretendeu-se identificar os possíveis padrões recorrentes tanto ofensivos quanto defensivos de uma equipe em múltiplos jogos frente a um mesmo adversário, assim como verificar possíveis alterações nos padrões com a mudança de adversário. Foram anotadas todas as DCEs e respectivas DPEs que conduziram a uma tentativa de finalização nas posses de bola (i.e., tanto as exitosas que culminaram com um arremesso quanto as que foram contidas pela defesa), em qualquer tipo de ataque. A avaliação da recorrência de padrões de DECs e DPEs levou em consideração as seguintes variáveis: i) período do jogo (i.e. primeiro, segundo, terceiro ou quarto perído), ii) tempo restante no período (e.g., último minuto de cada período), iii) zona da quadra, e iv) eficiência. No total, os seis jogos analisados produziram 898 posses de bola. Em cada posse de bola, todas as ações de desequilíbrio da defesa e as respectivas ações de proteção da meta foram analisadas, totalizando uma amostra de 1617 ações analisadas. A aquisição dos dados ocorreu por meio de anotação manual dos jogos, observados a partir de vídeos gravados de transmissões televisivas oficiais.

\subsubsection{Análise estatística}

A concordância na definição dos critérios de DCEs e DPEs, assim como na sua reprodutibilidade, foi calculada intra e inter-avaliadores através do coeficiente Kappa. Os índices do coeficiente foram comparados entre dia1 x dia2, dia1 x dia3, e dia2 x dia3. Na amostra constituída por seleções nacionais, a frequência de DCEs foi analisada, assim como foi realizada uma análise de correspondência simples para indicar as tendências de dinâmicas empregadas entre as equipes. $\mathrm{Na}$ amostra de equipes nacionais de categorias de base e adultas, os dados foram inicialmente filtrados por faixa etária e para cada uma delas foram analisadas a frequência e eficiência das DCEs através da estatística qui-quadrado, com análise de resíduos para identificação de significância na associação entre as frequências de cada nível das variáveis. Na amostra constituída por equipes espanholas e voltada para a frequência de DPEs e frequência de 
interação entre DCEs e DPEs foi empregada análise de correspondência. Todos os procedimentos foram realizados com o pacote estatístico $\mathrm{SAS}^{\circledR}$ 9.2. O valor de significância assumido em todas as análises foi de $\mathrm{p}<0,05$.

Informações adicionais sobre tipo de ataque e de defesa em cada posse de bola também foram anotadas. Os ataques foram classificados como contra-ataque, ataques posicionais e ataques interrompidos (i.e., quando um erro ou violação ocorreu).

\subsubsection{Resultados}

\subsubsection{Classes de dinâmicas}

\section{Dinâmicas de criação de espaço}

A versão final das DCEs consistiu em sete classes de dinâmicas ofensivas após o processo de validação, conforme descrito a seguir e ilustrado na Figura 33: i) Desmarque com Bola com Drible (DBCD): ações individuais nas quais a vantagem espaço-temporal para finalização é criada pelo jogador com bola, sem a cooperação de companheiros (e.g., deslocamento com um ou mais dribles, distanciando-se do defensor imediato, seguido da execução de um jump ou penetração com finalização em bandeja); ii) Desmarque com Bola sem Drible (DBSD): semelhante ao Desmarque com Bola com Drible, porém sem drible, usando apenas técnicas de fintas (e.g., finta seguida de arremesso); iii) Isolamento no Perímetro (IPe): jogador com bola é isolado no perímetro, normalmente na área central da meia-quadra ofensiva próximo à linha dos três pontos, enquanto os quatro companheiros ocupam espaços laterais de maneira que os defensores mantenham distância do jogador com bola (e.g., em instantes finais de uma posse de bola, com o isolamento do melhor finalizador); iv) Isolamento Interior (II): similar ao IPe, porém na região da área restrita (também denominado garrafão). Tanto o Isolamento no Perímetro quanto o Isolamento Interior são casos particulares do Desmarque com Bola com Drible e do Desmarque com Bola sem Drible, pois o espaço

é criado numa situação de $1 \times 1$, porém, considerados de forma separada por causa da 
ação coordenada de toda a equipe; v) Desmarque sem Bola (DSB): ação de dois jogadores, sendo que um cria o espaço e recebe o passe de seu companheiro (e.g., situações de back-door); vi) Bloqueio Direto (BD): um jogador atacante posiciona-se na trajetória do defensor de seu companheiro com bola, interrompendo a trajetória do defensor, criando assim espaço para o jogador com a bola (e.g., a ação amplamente difundida de pick'd'roll); vii) Bloqueio Indireto (BI): semelhante ao Bloqueio Direto, porém nenhum dos dois jogadores envolvidos na ação de bloqueio tem a posse da bola. Após a interrupção da trajetória do defensor pelo bloqueio, um terceiro companheiro dos jogadores de ataque passa a bola para o jogador livre de marcação.

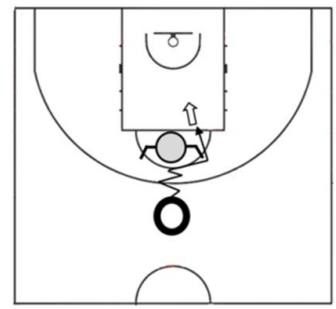

a)

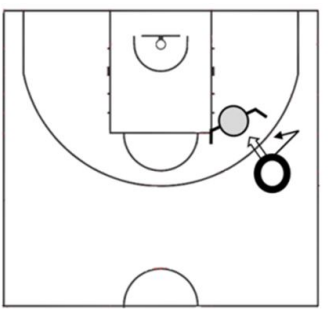

b)

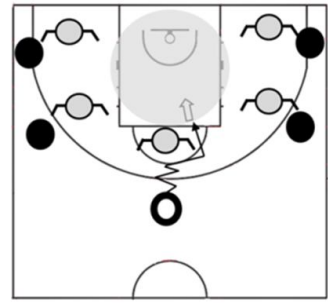

c)

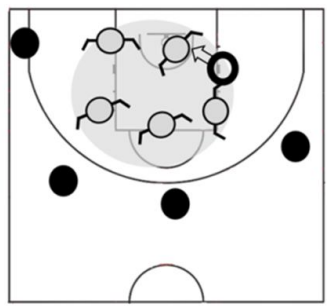

d)

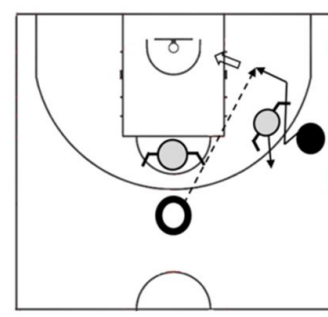

e)

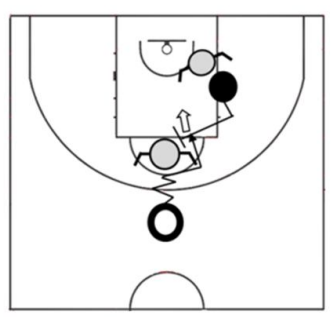

f)

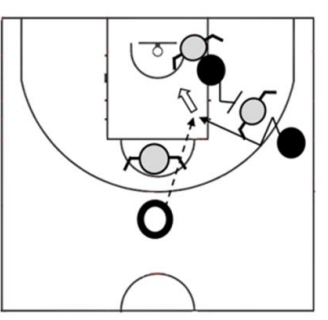

g)

Figura 33: a) Desmarque com bola com drible (DBCD); b) desmarque com bola sem drible (DBSD); c) isolamento no perímetro (IPe), d) isolamento interior (II), e) desmarque sem bola (DSB); f) bloqueio direto (BD); g) bloqueio indireto (BI), nos quais: $\bigcirc$ - jogador com bola; atacante sem bola; $ר$ - deslocamento com bola; $\longleftarrow$ - finta sem drible; $\longrightarrow$ - bloqueio; $\longrightarrow$-finalização; região cinza (33c and d) indica uma área vazia ou congestionada por defensores. 
Quando considerada a orientação de deslocamento na realização de um DCE, as direções consideradas para cada uma das DCEs são as seguintes. Para DBCD, DBSD, IPe e II: i) para o fundo da quadra; ii) para o meio da quadra ou área restrita/garrafão; iii) local, quando não há deslocamento. Para DSB: i) corte em direção à cesta; ii) corte em direção à periferia do ataque (i.e., próximo à linha de três pontos); local, quando o jogador permanece em seu local atual pois sua permanência implica desmarcação, dada a movimentação dos outros jogadores. Para os bloqueios, a orientação de deslocamento refere-se à direção na qual o bloqueio é realizado. No BD, são as seguintes: i) para o garrafão; ii) para a linha de fundo; iii) vertical, quando ocorre perpendicular à linha de fundo. No BI, são as seguintes: i) para dentro, quando o bloqueador se dirige a região do garrafão levando a uma ação de ida para a periferia do ataque por parte do receptor; ii) para fora, no caso contrário; iii) sequencial, quando o lance envolve mais de um bloqueador subsequente, no qual a orientação é, geralmente, diagonal em relação às linhas da quadra; iv) horizontal, quando ocorre paralelo à linha de fundo.

\section{Dinâmicas de proteção do espaço}

Com o estudo das dinâmicas de proteção do espaço constatou-se a relação de uma DCE para diversas possibilidades de respectivas DPEs. Por exemplo, para a ação ofensiva de bloqueio na bola, as classes defensivas foram diferenciadas entre comportamentos do defensor do homem da bola e do defensor do bloqueador. Ainda, para tentar impedir a ação do homem da bola, o defensor pode atuar de mais de uma maneira. Todas essas diferenciações possuem relevância semântica uma vez que podem ser especificadas na estratégia, com impacto bastante distinto na oposição. Os critérios utilizados para definição das classes de DPEs foram os seguintes: 1) os comportamentos possíveis para defender cada uma das DCEs, assumindo-se a defesa como reativa ao ataque. Assim, as classes de DPEs são condicionadas pelo número de jogadores envolvidos na ação ofensiva, uma vez que a característica de cada par atacante-defensor

é considerado para a classificação das DPEs; 2) a orientação relativa do corpo do defensor em relação ao corpo do atacante. Na sequência são apresentadas as classes restantes após o processo de validação. 
As DPEs utilizadas para defender ações de DBCD, DBSD e IPe (Figura 33) são: a) orientado para o meio: o defensor orienta o atacante para o meio da quadra. A rotação corporal do defensor e o direcionamento dos seus pés bloqueiam diagonalmente a progressão do atacante para o fundo da quadra; b) orientado para o fundo: o defensor orienta o atacante para o fundo da quadra. A rotação corporal e direcionamento dos pés do defensor bloqueiam diagonalmente a progressão do atacante para o garrafão (i.e., área pintada próxima à cesta, em formato trapezoidal); c) neutro: não há lado preferencial para penetração do atacante. Da região central do ataque até a lateral, o defensor mantém suas costas sempre alinhadas com a cesta ou paralela à linha de fundo e os pés sempre estão orientados de forma perpendicular à linha de três pontos. Na região da zona morta (i.e., após uma projeção imaginária da linha de lance livre em direção à linha lateral, em direção à intersecção da linha de fundo com a linha lateral) a rotação corporal e a orientação dos pés são, respectivamente, perpendicular e paralela à linha de fundo (Figura 34).

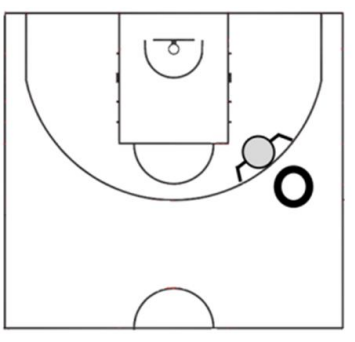

a)

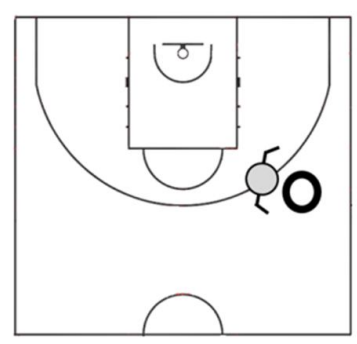

b)

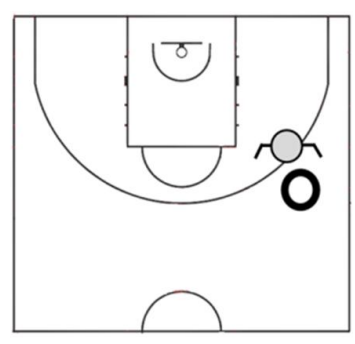

c)

Figura 34: DPEs para defesa de DCEs em situações de 1x1 (DBCD, DBSD, IPe): a): neutro, b) orientado para o fundo, c) orientado para o meio.

As DPEs utilizadas para defender ações de II são (Figura 35): a) neutro posterior: defensor mantem-se atrás do atacante, sem direcionamento de um lado preferencial; b) neutro anterior: defensor mantem-se à frente do atacante, sem direcionamento de um lado preferencial; c) orientado $3 / 4$ para cima: defensor com rotação corporal tal que envolve $3 / 4$ do atacante, impedindo o passe ou o deslocamento na direção da linha de fundo; d) orientado 3/4 para baixo: defensor com rotação corporal 
tal que envolve $3 / 4$ do atacante, impedindo o passe ou o deslocamento na direção do centro do garrafão (Figura 35).

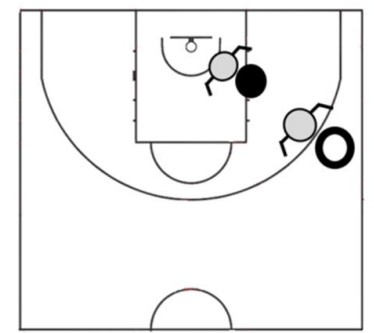

a)

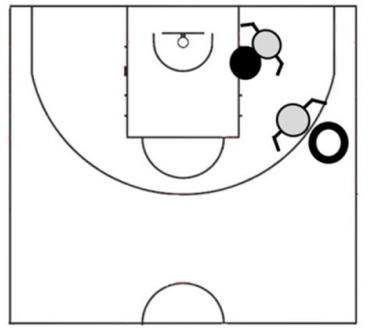

c)

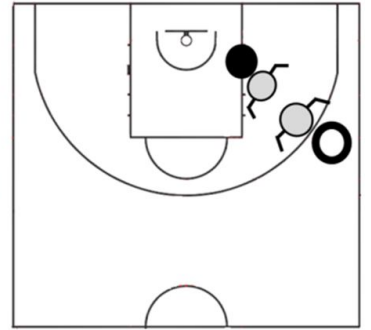

b)

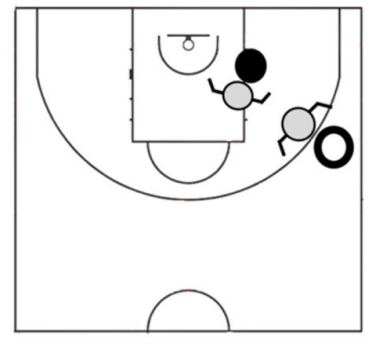

d)

Figura 35: DPEs para defesa do DCE isolamento interior (II), no momento que precede o passe a partir do perímetro: a) neutro; b) 3/4 para cima; c) 3/4 para baixo; d) pela frente.

As DPEs utilizadas para defender o receptor da bola em ações de DSB são: a) afastado: o atacante desloca-se e ocupa um espaço vazio sem nenhuma obstrução imposta pelo defensor, que o monitora a uma distância suficiente para não ser ultrapassado; b) próximo: a linha de passe e a trajetória de deslocamento do atacante são obstruídas pelo defensor (Figura 36). Para o passador, as DPEs são as mesmas descritas para a defesa do DBCD, DBSD e IPe (Figura 34). 


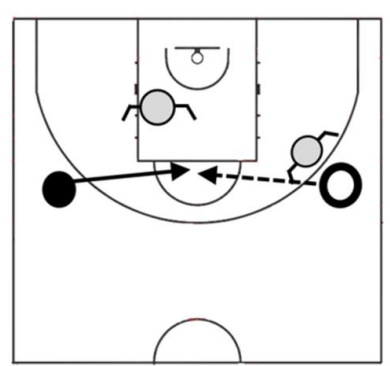

a)

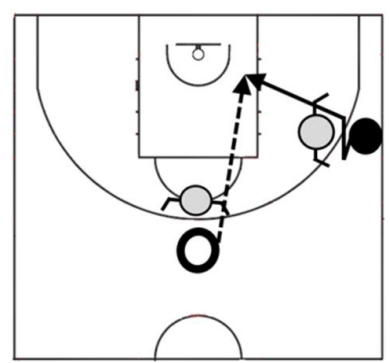

b)

Figura 36: DPEs para defesa do DCE desmarque sem bola (DSB): a) afastado; b) próximo.

As DPEs utilizadas para defender as ações de BD e BI precisam ser caracterizadas tanto para o denfensor do homen da bola quanto para o defensor do bloqueador. Dessa forma o texto a seguir dará conta das DPEs para os dois jogadores envolvidos em cada uma dessas dinâmicas ofensivas.

As DPEs utilizadas para defender ações de BD - defensor do homem da bola são (Figura 37): a) pela frente: o defensor passa junto ao atacante com bola, pela frente do bloqueador, com a postura defensiva preservada e conservando-se entre o atacante e a cesta; b) pelo meio: o defensor dá continuidade à sua trajetória passando entre o bloqueador e o defensor do bloqueador para seguir na defesa do atacante com bola; c) por trás: o defensor do jogador com bola passa por trás do defensor do bloqueador para seguir defendendo o jogador que recebeu o bloqueio; d) inversão: o defensor realiza uma rotação corporal obstruindo o deslocamento do atacante na direção do bloqueio; e) troca defensiva: o defensor do homem da bola e o defensor do bloqueador trocam a defesa de seus respectivos atacantes; f) dobra defensiva: tanto o defensor do homem da bola quanto o defensor do bloqueador defendem, momentaneamente e com elevada pressão espacial, o jogador com bola. 


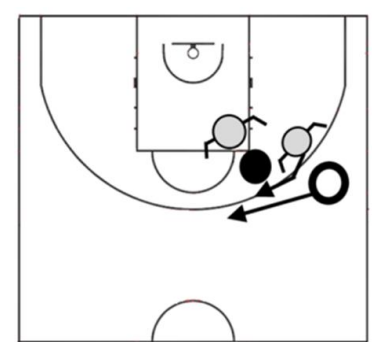

a)

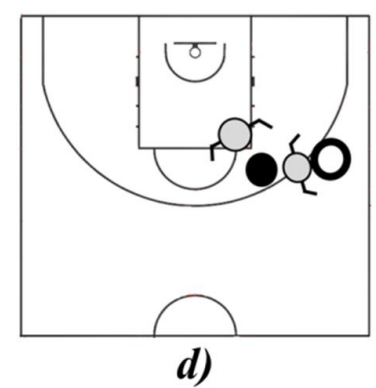

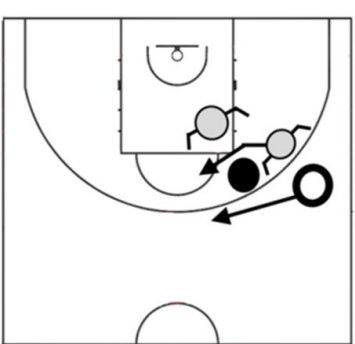

b)

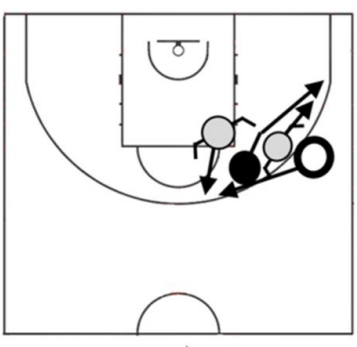

e)

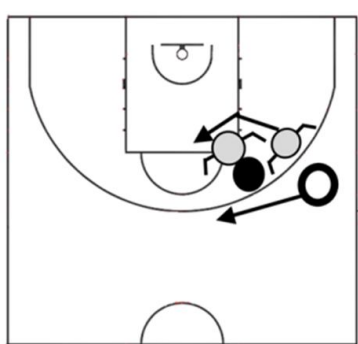

c)

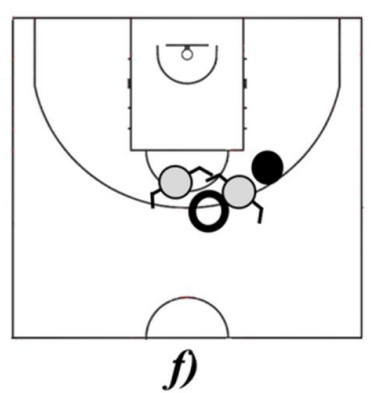

Figura 37: DPEs para defesa do DCE bloqueio direto (BD)- defesa do homem da bola: a) por cima; b) pelo meio; c) por baixo; d) inversão; e) troca defensiva; f) dobra defensiva.

As DPEs utilizadas para defender ações de BD - defensor do bloqueador são (Figura 38): a) sustentar: defensor sustenta posição próxima ao atacante, com contato físico impondo certa restrição ao posicionamento do bloqueador atacante; b) mostrar: deslocamento do defensor na projeção da posição ocupada pelo atacante bloqueador, de maneira a retardar a progressão do atacante com bola, cujo defensor foi bloqueado; c) afastar: defensor afasta-se do atacante bloqueador para realizar a cobertura do defensor que foi bloqueado; d) abrir: defensor do bloqueador afasta-se do seu atacante para dar passagem ao defensor bloqueado e retorna à sua posição na sequência; e) troca defensiva: o defensor do bloqueador e o defensor bloqueado trocam seus respectivos atacantes defendidos; f) dobra defensiva: o defensor do bloqueador e o defensor bloqueado realizam marcação dupla sobre o atacante com bola, após este ter recebido o bloqueio. 


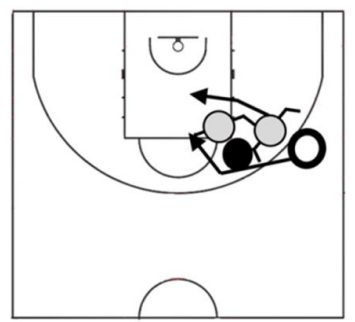

a)

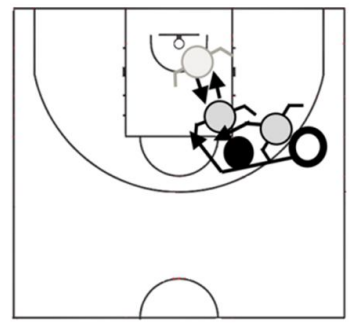

d)

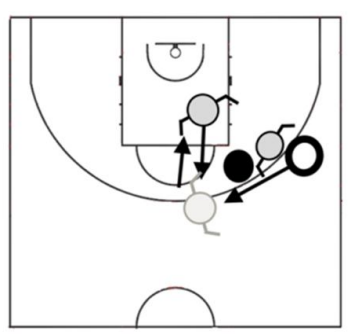

b)

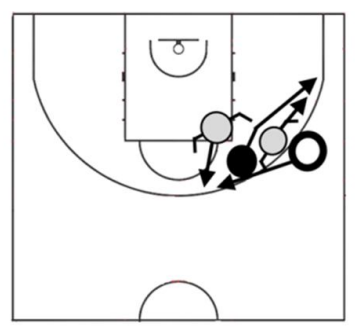

e)

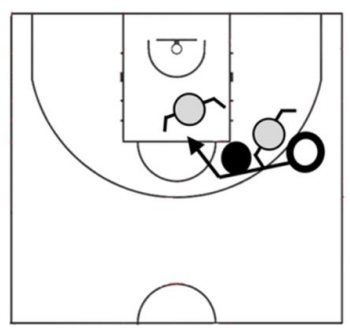

c)

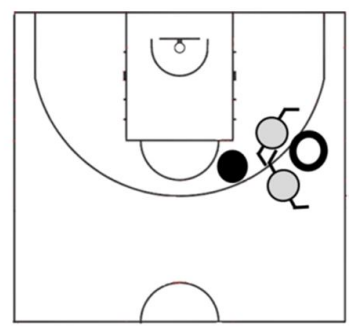

f)

Figura 38: DPEs para defesa do DCE bloqueio direto (BD) - defesa do bloqueador: a) sustentar; b) mostrar; c) afastar; d) abrir; e) troca defensiva; f) dobra defensiva.

As DPEs utilizadas para defender a ação do receptor do bloqueio em um BI são (Figura 39): a) pela frente: o defensor passa junto ao atacante com bola, pela frente do bloqueador, com a postura defensiva preservada e o seu corpo mantendo-se entre o atacante e a cesta; b) pelo meio: o defensor dá continuidade à sua trajetória passando entre o bloqueador e o defensor do bloqueador para seguir na defesa do atacante com bola; c) por trás: o defensor do jogador com bola passa por trás do defensor do bloqueador para seguir defendendo o jogador que recebeu o bloqueio; d) inversão: o defensor realiza uma rotação corporal obstruindo o deslocamento do atacante na direção do bloqueio; e) troca defensiva: o defensor do homem da bola e o defensor do bloqueador trocam a defesa de seus respectivos atacantes; f) dobra defensiva: o defensor do homem da bola e o defensor do bloqueador defendem, momentaneamente e com elevada pressão espacial, o jogador com bola. 


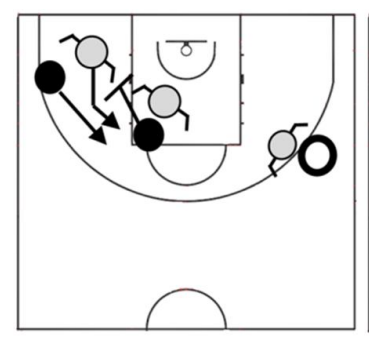

a)

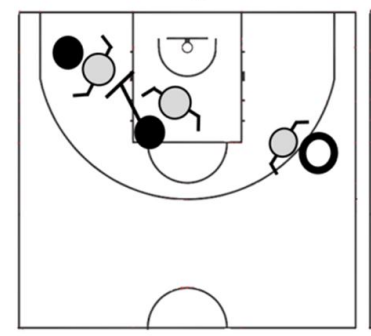

d)

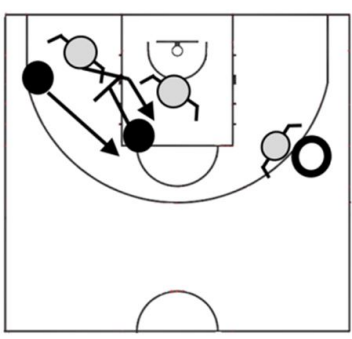

b)

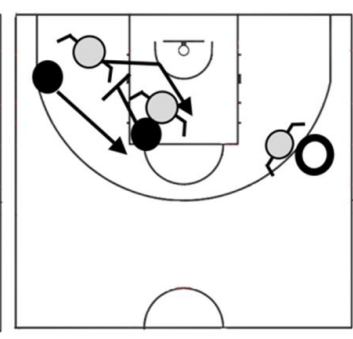

c)

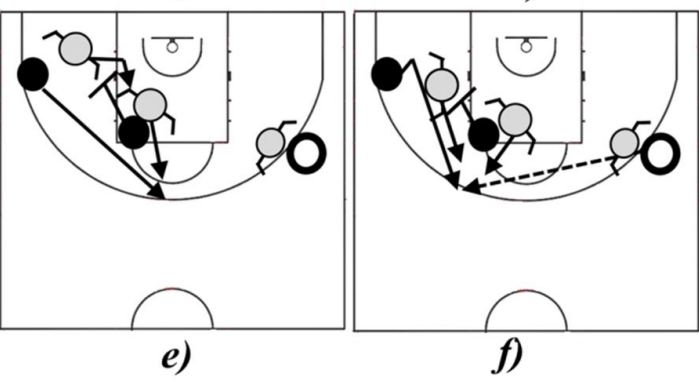

Figura 39: DPEs para defesa do bloqueio indireto (BI) - receptor do bloqueio: a) por cima; b) pelo meio; c) por baixo; d) inversão; e) trocar; f) dobrar.

As DPEs utilizadas para defender a ação do bloqueador em um BI são (Figura 40): a) sustentar: o defensor sustenta posição próxima ao atacante, com contato físico, impondo certa restrição ao posicionamento do bloqueador atacante; b) mostrar: deslocamento do defensor na projeção da posição ocupada pelo atacante bloqueador, de maneira a retardar a progressão do atacante cujo defensor foi bloqueado; c) afastar: defensor afasta-se do atacante bloqueador para realizar a cobertura do defensor que foi bloqueado; d) abrir: defensor do bloqueador afasta-se do seu atacante para dar passagem ao defensor bloqueado e retorna à sua posição na sequência; e) colidir: defensor do bloqueador obstrui a trajetória do atacante bloqueado, retardando sua progressão para facilitar a recuperação defensiva por parte do seu defensor; f) troca defensiva: o defensor do bloqueador e o defensor bloqueado trocam seus respectivos atacantes defendidos; g) dobra defensiva: o defensor do bloqueador e o defensor bloqueado realizam marcação dupla sobre o atacante que recebeu o bloqueio, caso esse receba o passe. 


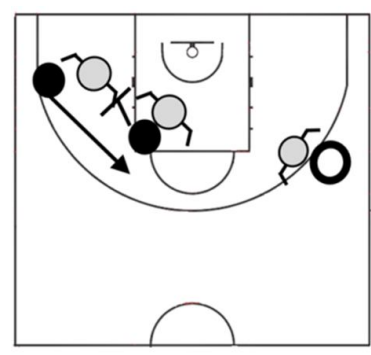

a)

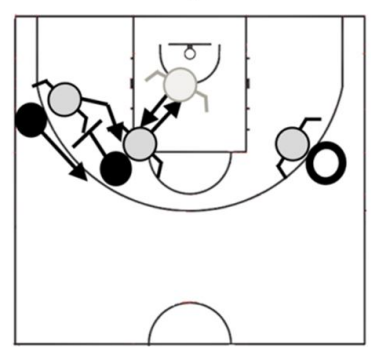

d)

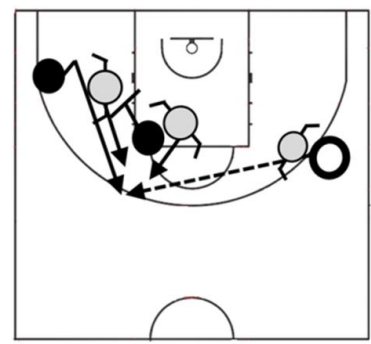

g)

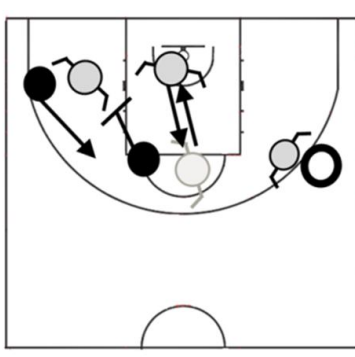

b)

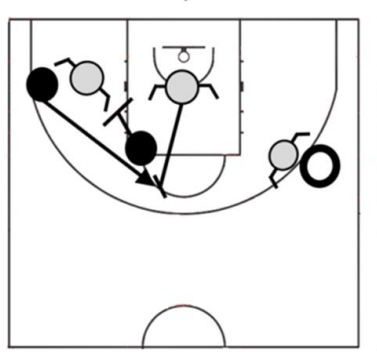

e)

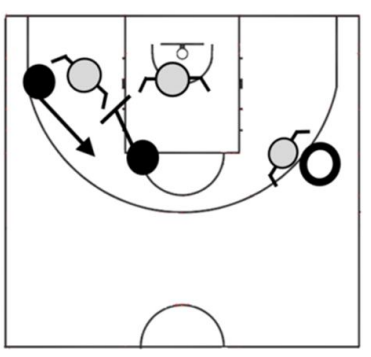

c)

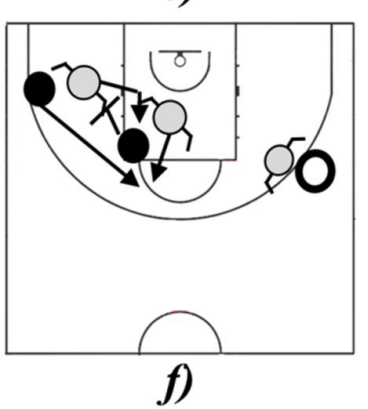

Figura 40: DPEs para defesa do bloqueio indireto (BI) - bloqueador: a) sustentar; b) mostrar; c) afastar; d) abrir; e) colidir; f) troca defensiva; g) dobra defensiva.

As DPEs utilizadas para defender a ação do passador em um BI são semelhantes às descritas para a defesa do DBCD, DBSD e IPe. A Tabela 1 apresenta as DCEs e as DPEs correspondentes validadas no estudo. 
Tabela 1: Dinâmicas de criação de espaço (DCE) e as correspondentes dinâmicas de proteção de espaço (DPE).

\begin{tabular}{|c|c|c|}
\hline N.P. & DCE & DPE \\
\hline $1 \times 1$ & DBCD, DBSD, IPe & $\begin{array}{l}\text { neutro; orientado para o meio; } \\
\text { orientado para o fundo. }\end{array}$ \\
\hline $1 \times 1$ & II & $\begin{array}{l}\text { neutro anterior; neutro posterior; } \\
\text { 3/4 para cima; } 3 / 4 \text { para baixo. }\end{array}$ \\
\hline $2 \times 2$ & DSB & afastado; próximo. \\
\hline $2 \times 2$ & BD- homem da bola & $\begin{array}{l}\text { por cima; pelo meio; por baixo; } \\
\text { inversão; troca; dobra. }\end{array}$ \\
\hline $2 \times 2$ & BD- bloqueador & $\begin{array}{l}\text { sustentar; mostrar; afastar; abrir; } \\
\text { troca; dobra. }\end{array}$ \\
\hline $3 \times 3$ & BI- receptor do bloqueio & $\begin{array}{l}\text { por cima; pelo meio; por baixo; } \\
\text { inversão; trocar; dobrar. }\end{array}$ \\
\hline $3 \times 3$ & BI- bloqueador & $\begin{array}{l}\text { sustentar; mostrar; afastar; abrir; } \\
\text { colidir; troca; dobra. }\end{array}$ \\
\hline
\end{tabular}

\subsubsection{Reprodutibilidade intra e inter-observadores}

Os coeficientes de reprodutibilidade intra- e inter-avaliadores dos critérios definidores das classes de DCEs e DPEs são apresentados na Tabela 2. Todos os coeficientes de reprodutibilidade apresentaram valores que indicavam ao menos concordância substancial. Não foram verificadas diferenças entre os valores de Kappa intra e inter-observadores para nenhuma classe de DCE ou DPE ( $p>0.05)$. 
Tabela 2: Coeficientes Kappa intra- e inter-observadores para os critérios de DCEs e DPEs são indicados para três momentos distintos (dia1 x dia2, dia1 x dia3, e dia2 $\times$ dia3).

\begin{tabular}{|c|c|c|c|c|}
\hline & & Observador 1 & Observador 2 & Observador 3 \\
\hline \multirow{3}{*}{ DCEs } & Observador 1 & $0,83 / 0,79 / 0,81$ & $0,71 / 0,73 / 0,75$ & $0,79 / 0,81 / 0,80$ \\
\hline & Observador 2 & $0,70 / 0,73 / 0,71$ & $0,78 / 0,85 / 0,80$ & $0,80 / 0,78 / 0,78$ \\
\hline & Observador 3 & $0,81 / 0,81 / 0,83$ & $0,75 / 0,78 / 0,76$ & $0,85 / 0,80 / 0,76$ \\
\hline \multirow{3}{*}{ DPEs } & Observador 1 & $0,96 / 0,92 / 0,96$ & $0,88 / 0,89 / 0,89$ & $0,89 / 0,90 / 0,90$ \\
\hline & Observador 2 & $0,88 / 0,89 / 0,89$ & $0,95 / 0,93 / 0,95$ & 0,92/0,90/0,90 \\
\hline & Observador 3 & $0,89 / 0,90 / 0,90$ & $0,92 / 0,90 / 0,90$ & $0,95 / 0,96 / 0,97$ \\
\hline
\end{tabular}

3.3.3.3 Análise ofensiva, defensiva e da oposição entre equipes de basquetebol

\section{Seleções nacionais adultas}

Entre todas as seleções nacionais, verificou-se significante predominância de ataques posicionais, em relação aos contra-ataques e posses de bola nas quais o ataque não foi concluído $(\mathrm{p}<0,05)$, sendo as proporções médias verificadas, respectivamente, de: $87 \%, 10,5 \%$ e 2,5\% do total de 1902 posses de bola analisadas (Figura 41). Para a análise, apenas os ataques posicionais foram considerados. 


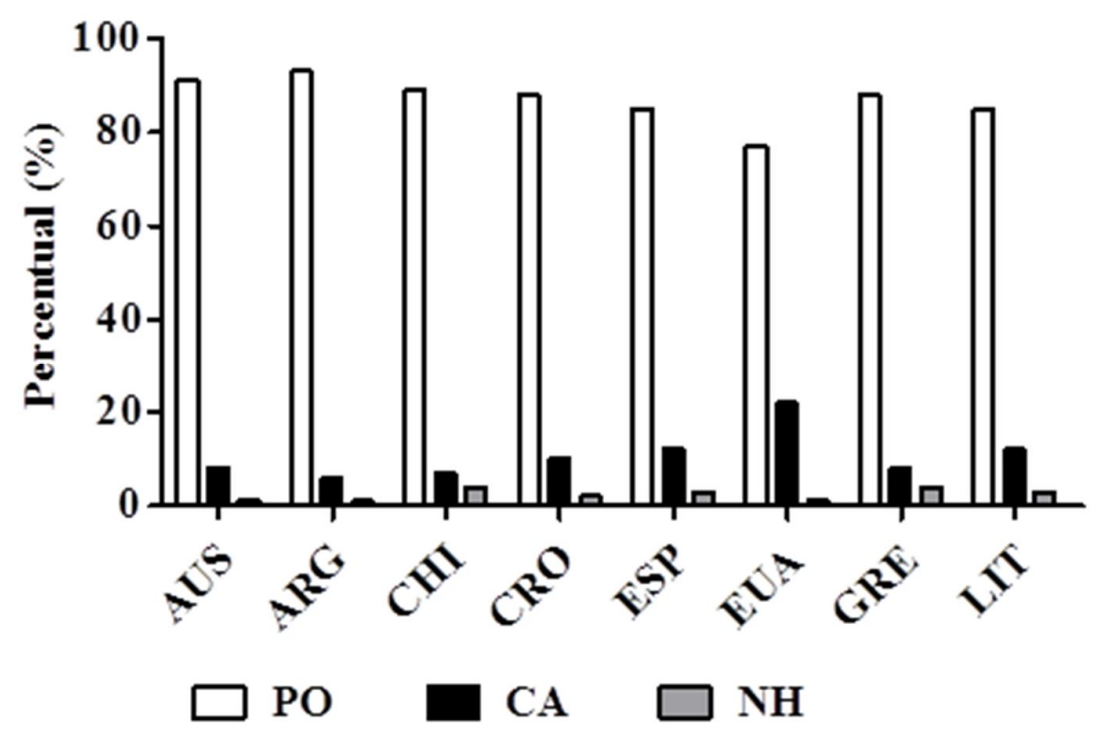

Figura 41: Percentual de ataques posicionais, contra-ataques e interrupções entre equipes nacionais: Australia (AUS), Argentina (ARG), China (CHI), Croacia (CRO), Espanha (ESP), Estados Unidos (EUA), Grécia (GRE), Lituania (LIT) Pposicional - PO, contra-ataque - CA, e não houve ataque NH.

Os ataques posicionais terminaram em: a) oportunidades de finalização depois de uma DCE (1308 posses de bola-68.7\% do total); b) arremessos forçados/finalizações sem realização de uma DCE (164 posses de bola-8.6\% do total); c) lances-livres (92 posses de bola- $4.8 \%$ do total); e d) erros (338 posses de bola-17.9\% do total). Entre as posses de bola que terminaram em oportunidades de finalização, a distribuição de frequência entre as DCEs é apresentada na Tabela 3. 
Tabela 3: Classes de dinâmicas de criação de espaço (DCEs) para as posses de bola que terminaram em oportunidade de finalização, sendo valores expressos em percentual.

\begin{tabular}{ccccccc}
\hline DBCD & DBSD & IPe & II & DSB & BD & BI \\
\hline 14.9 & 3.2 & 9.0 & 16.7 & 11.8 & 34.8 & 9.6 \\
\hline
\end{tabular}

DBCD: desmarque com bola com drible; DBSD: desmarque com bola sem drible; IPe: isolamento no perímetro; II: isolamento interior; DSB: desmarque sem bola; BD: bloqueio direto; BI: bloqueio indireto.

A Figura 42 apresenta um plote em mosaico da frequência das DCEs por seleção nacional analisada. Há evidente predominância do BD em relação às demais DCEs para a maioria das equipes. Além disso, II foi bastante frequente entre as equipes, mas ainda mais para Australia e China. 


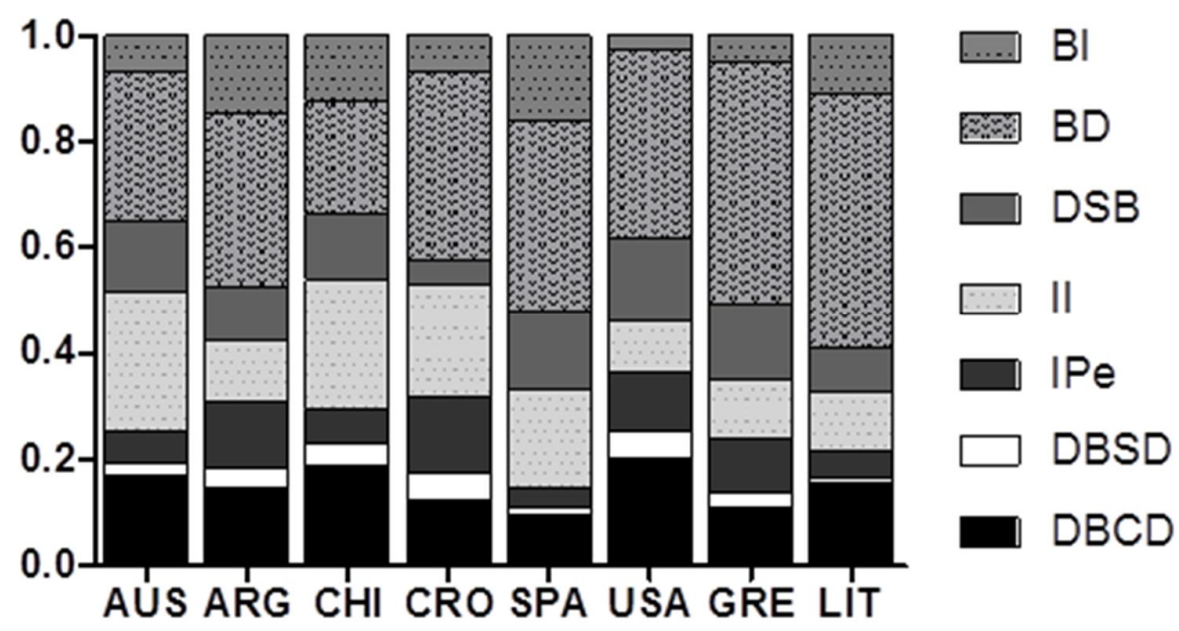

Figura 42: Percentual de ocorrência das dinâmicas de criação de espaço (DCEs) para cada seleção nacional. BI: bloqueio indireto; BD: bloqueio direto ; DSB: desmarque sem bola; II: isolamento interior; IPe: isolamento no perímetro; DBSD: desmarque com bola sem drible; DBCD: desmarque com bola com drible. AUS: Austrália; ARG: Argentina; CHI: China; CRO: Croácia; ESP: Espanha; EUA: Estados Unidos; GRE: Grécia; LIT: Lituânia.

O resultado da análise de correspondência para cada nível das duas variáveis, DCEs e seleções nacionais, foi gerado considerando os primeiros três primeiros eixos da estatística. Estes três eixos atingiram a margem recomendada de $80 \%$ do valor de explicação da inércia total ( $82 \%$ da inércia total explicada). A representação de cada nível das variávies no sistema de coordenadas, definido pelos três eixos conservados na análise é informada pelo output da qualidade da representação. Uma qualidade baixa significa que o número de dimensões da análise não representa adequadamente o respectivo nível. Nos dados analisados, todos os níveis de ambas variáveis atingiram níveis razoáveis ou elevados de qualidade de representação com os três eixos de análise (Tabela 4).

Além disso, a inércia relativa representa a proporção da inércia total atribuída ao respectivo ponto, independentemente do número de eixos escolhidos. Uma solução pode representar um ponto com elevada qualidade, mas o mesmo ponto pode não contribuir muito para a inércia total. Nos dados analisados, II $(0,234)$ e BI $(0,225)$ foram 
as variáveis que mais contribuiram para a inércia total das classes de DCEs. Para a inércia total das equipes, há um padrão homogêneo com pesos igualmente distribuídos (Tabela 4).

Tabela 4: Valores da análise de correspondência e inércia relativa expressas para cada nível das duas variáveis: dinâmicas de criação de espaço (DCEs) e seleções nacionais.

\begin{tabular}{|c|c|c|c|}
\hline & & Qualidade & Inércia relativa \\
\hline \multirow{7}{*}{ 占 } & DBCD & 0.435 & 0,080 \\
\hline & DBSD & 0.884 & 0,061 \\
\hline & IPe & 0.958 & 0,143 \\
\hline & II & 0.853 & 0,234 \\
\hline & DSB & 0.570 & 0,093 \\
\hline & $\mathrm{BD}$ & 0.876 & 0,165 \\
\hline & BI & 0.947 & 0,225 \\
\hline \multirow{8}{*}{ 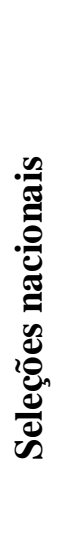 } & AUS & 0.925 & 0,117 \\
\hline & $\mathrm{ARG}$ & 0.780 & 0,102 \\
\hline & $\mathrm{CHI}$ & 0.918 & 0,145 \\
\hline & CRO & 0.618 & 0,124 \\
\hline & ESP & 0.959 & 0,141 \\
\hline & GRE & 0.884 & 0,113 \\
\hline & LIT & 0.688 & 0,095 \\
\hline & EUA & 0.842 & 0,163 \\
\hline
\end{tabular}

DBCD: desmarque com bola com drible; DBSD: desmarque com bola sem drible; IPe: isolamento no perímetro; II: isolamento interior; DSB: desmarque sem bola; BD: bloqueio direto; BI: bloqueio indireto.AUS: Austrália; ARG: Argentina; CHI: China; CRO: Croácia; ESP: Espanha; GRE: Grécia; LIT:Lituânia; EUA: Estados Unidos. 
Os valores acima mencionados foram utilizados para gerar um mapa de simetria da análise de correspondência, apresentada na Figura 43. Os níveis das variáveis DCEs e seleções nacionais são apresentados na mesma escala, interpretados a partir da distância qui-quadrado $\left(\chi^{2}\right)$. No mapa, é possível visualizer as tendências principais das equipes em termos das preferências de utilização das DCEs, com a comparação de um único ponto da nuvem da variável - seleções nacionais - em relação a todos os pontos da variável - DCEs. Ainda, a distância entre dois pontos da mesma variável pode ser interpretada como a medida de sua similaridade em relação à outra variável. A direção de dispersão das classes de DCEs e seleções nacionais indica as preferências das ações ofensivas determinadas pelas estratégias das equipes. Portanto, considerando a frequência acumulada das DCEs, Grécia, Lituania e Argentina apresentaram maior similaridade em comparação à Australia, por exemplo, que jogou com frequências de DCEs mais próximas ao perfil da China. Ainda, a Espanha apresentou uma estratégia de jogo que, consistentemente, diferiu das outras equipes, com uso frequente não apenas do bloqueio direto mas também do bloqueio indireto, além de alternâncias com jogo interior. A China utilizou com frequência ações de isolamento interior com frequência e a Argentina foi a seleção com frequência mais equilibrada dentre as distintas classes. É interessante enfatizar que a opção por um mapa de simetria foi feita pela melhor visualização dos dois fatores. 


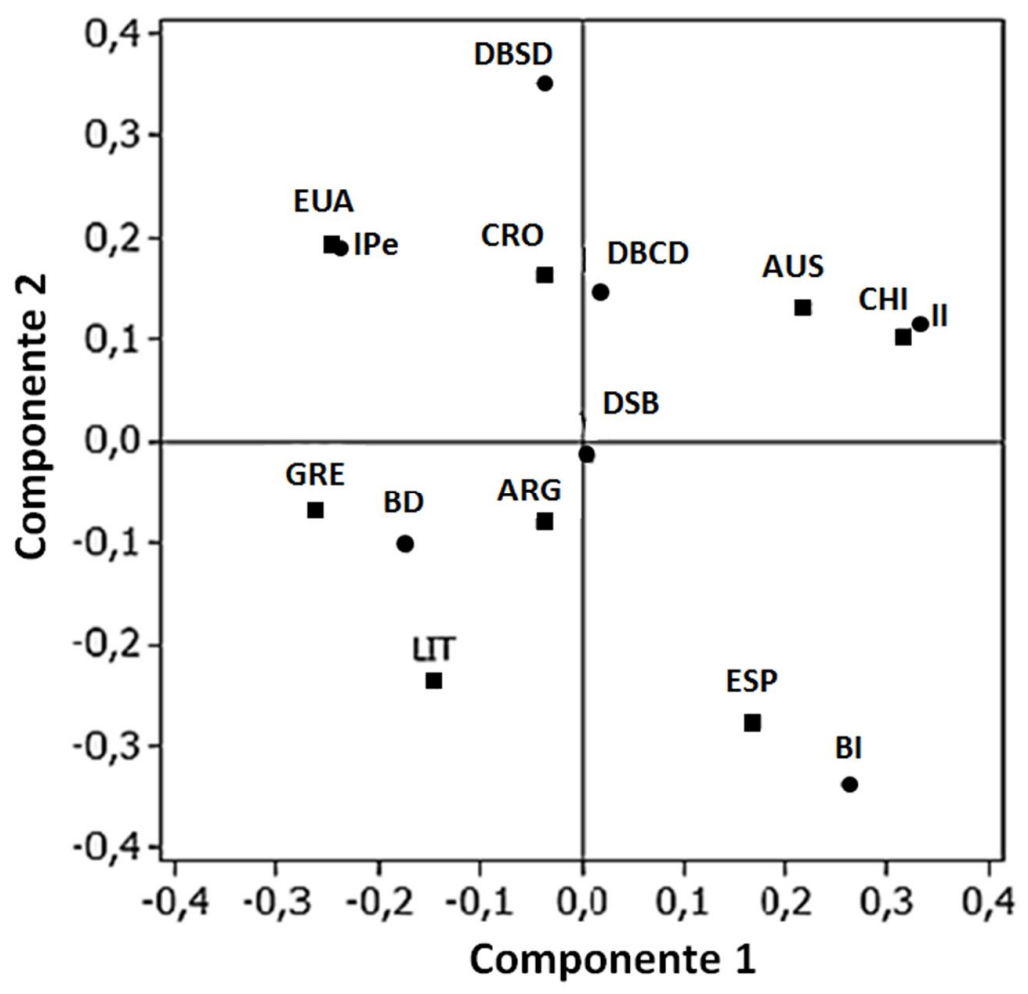

Figura 43: Análise de correspondência: mapa de simetria com as variáveis seleções nacionais e dinâmicas de criação de espaço, nas quais: ARG: Argentina; AUS: Australia; CHI: China; CRO: Croacia; GRE: Grécia; LIT: Lituania; ESP: Espanha; EUA: Estados Unidos da América. DBCD: desmarque com bola com drible; DBSD: desmarque com bola sem drible; IPe: isolamento no perímetro; II: isolamento interior; DSB: desmarque sem bola; BD: bloqueio direto; BI: bloqueio indireto.

Equipes paulistas masculinas de categorias de base e adultas

Para cada uma das categorias etárias verificou-se significante predominância de ataques posicionados, em relação aos contra-ataques e posses de bola nas quais o ataque não foi concluído $(\mathrm{p}<0,05)$, conforme indicado na Figura 44. Porém, entre as faixas etárias não foi verificada diferença entre as proporções de ocorrência dos tipos de ataque. 


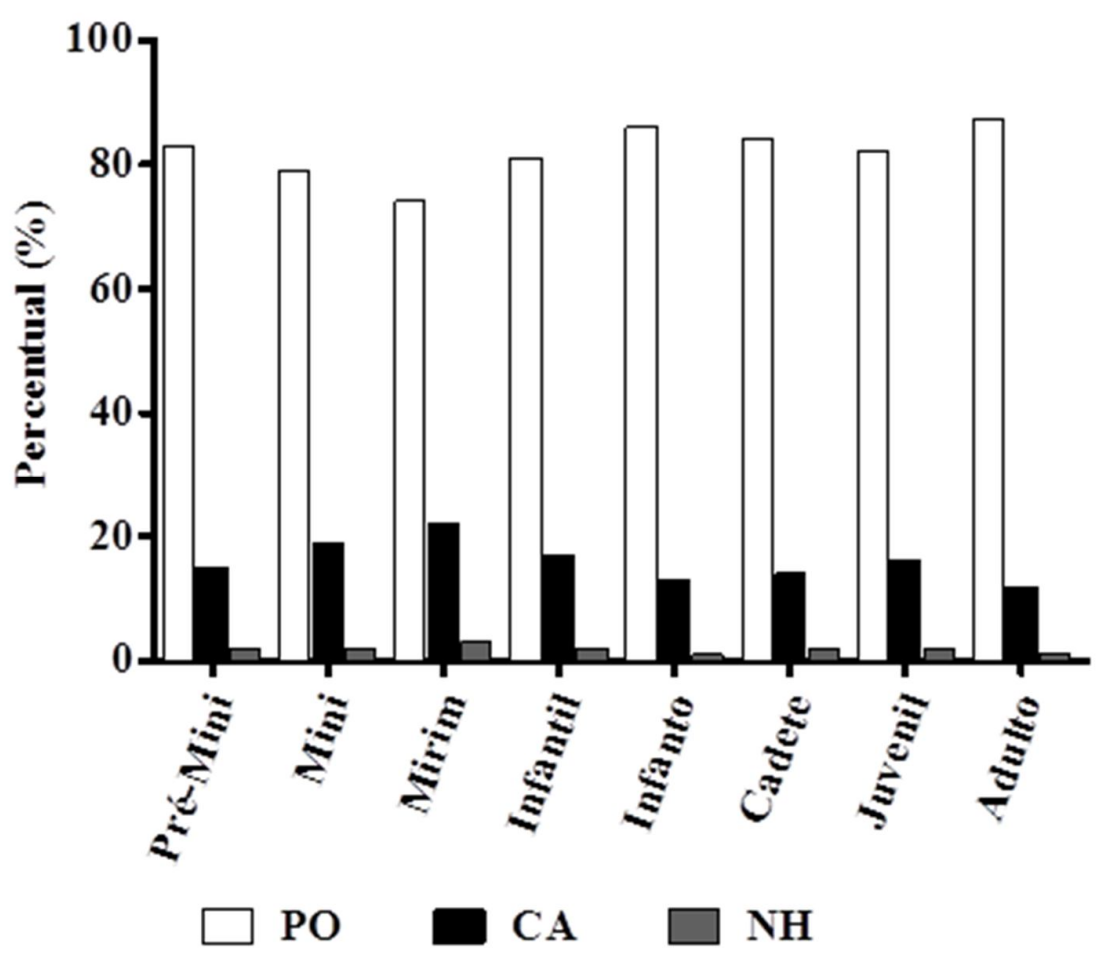

Figura 44: Percentual de ocorrência dos tipos de ataque (posicional - PO, contra-ataque - CA, e não houve ataque - NH) em cada categoria etária.

Não foram encontradas diferenças significantes entre as categorias etárias para a ocorrência de nenhuma das classes de DCEs contra defesa individual (Figura 45). Porém na análise das idades isoladamente, no pré-mini, mini e mirim a frequência de DBCD foi maior que todas as demais $(\mathrm{p}<0,05)$. Para o infantil, a frequência de DBCD não foi maior apenas que $\mathrm{BD}(\mathrm{p}<0,05)$. No infanto, $\mathrm{DBCD}$ teve frequência maior apenas em relação a DBSD, IPe e II e o BD apresentou frequência mais elevada que IPe $(\mathrm{p}<0,05)$. No cadete foi verificado maior equilíbrio entre as frequências de DCEs, sendo DBCD maior apenas que DSB e BI $(\mathrm{p}<0,05)$. Além disso, somente BD ocorreu mais vezes que IPe $(p<0,05)$. No juvenil e adulto, DBCD foi significantemente mais frequente que DBSD, IPE, II e DSB $(\mathrm{p}<0,05)$. E BD foi mais frequente que DBSD, DSB, II e IPe $(\mathrm{p}<0,05)$. 


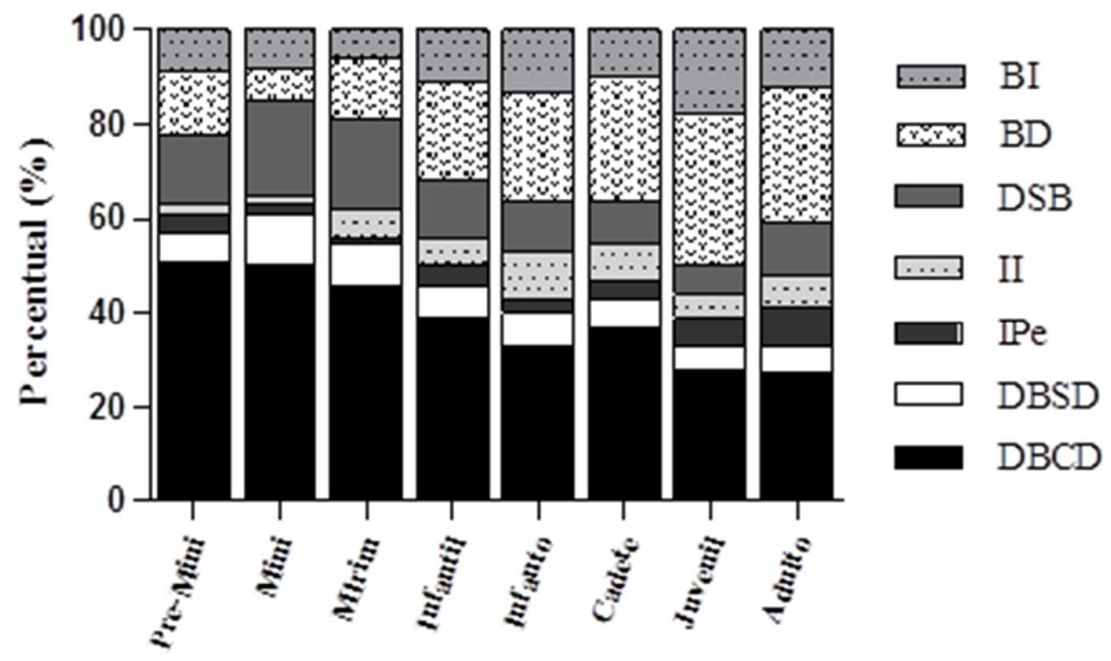

Figura 45: Percentual de ocorrência das dinâmicas de criação de espaço (DCEs) realizadas em posses de bola contra defesa individual. Onde: DBCD: Desmarque com Bola com Drible; DBSD: Desmarque com Bola Sem Drible; IPe: Isolamento no Perímetro; II: Isolamento Interior; DSB: Desmarque sem Bola; BD: Bloqueio Direto; BI: Bloqueio Indireto.

A frequência das DCEs para ações ofensivas contra defesa zona é apresentada na Figura 46. Assim como verificado contra defesa individual, contra defesa zona não foram encontradas diferenças significantes entre as faixas etárias para a ocorrência de nenhuma das classes de DCEs. Na análise de cada faixa etária, pré-mini, mini, mirim, infantil, infanto, cadete, juvenil e adulto apresentaram maior frequência de DBCD do que todas as demais DCEs $(\mathrm{p}<0,05)$, exceto DSB. Em todas estas faixas etárias o DSB apresentou frequência superior a DBSD, IPe, II, BD e BI $(\mathrm{p}<0,05)$. 


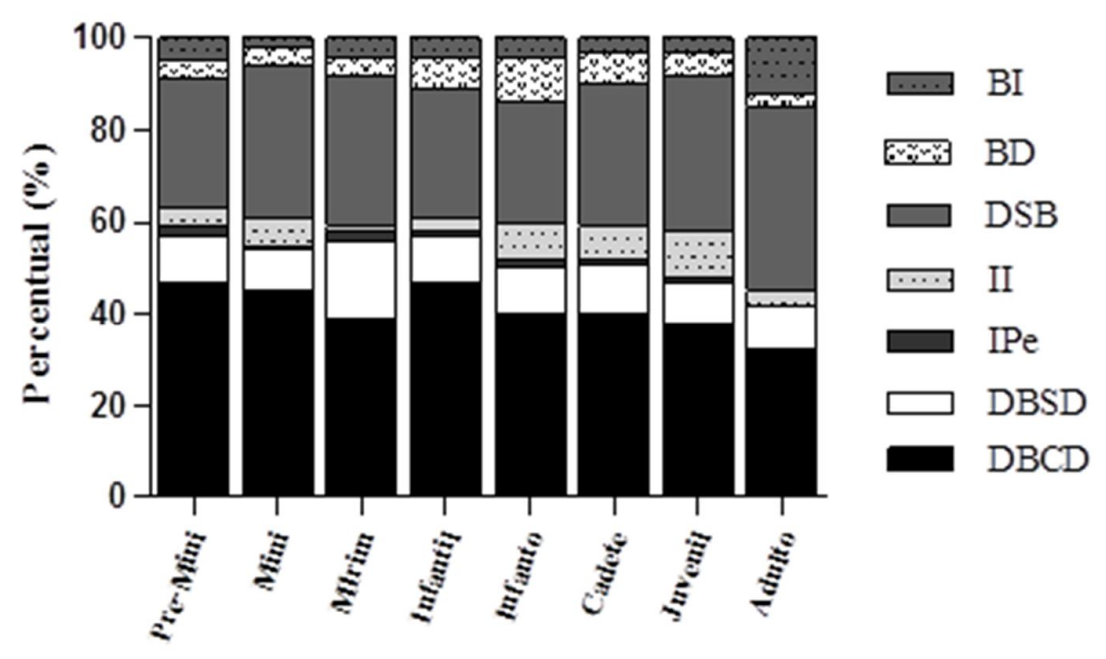

Figura 46: Percentual de ocorrência das dinâmicas de criação de espaço (DCEs) realizadas em posses de bola contra defesa por zona. Onde: DBCD: Desmarque com Bola com Drible; DBSD: Desmarque com Bola Sem Drible; IPe: Isolamento no Perímetro; II: Isolamento Interior; DSB: Desmarque sem Bola; BD: Bloqueio Direto; BI: Bloqueio Indireto.

A eficácia por categoria etária na utilização das DCEs foi determinada a partir da proporção entre a frequência de êxitos na finalização decorrente da realização da DCE e a frequência total de ocorrência da DCE em questão (Figura 47). Não foi verificada nenhuma diferença significante para a eficiência de uma dada DCE entre as diferentes categorias etárias. Assim como não foi encontrada diferença significante para a eficiência de uma DCE em uma mesma categoria etária para os dois tipos de defesa. Apenas o IPe e o II na categoria mirim, contra defesa individual, apresentaram eficiência superior às demais DCEs na mesma categoria etária e contra o mesmo tipo de defesa $(\mathrm{p}<0,05)$. 

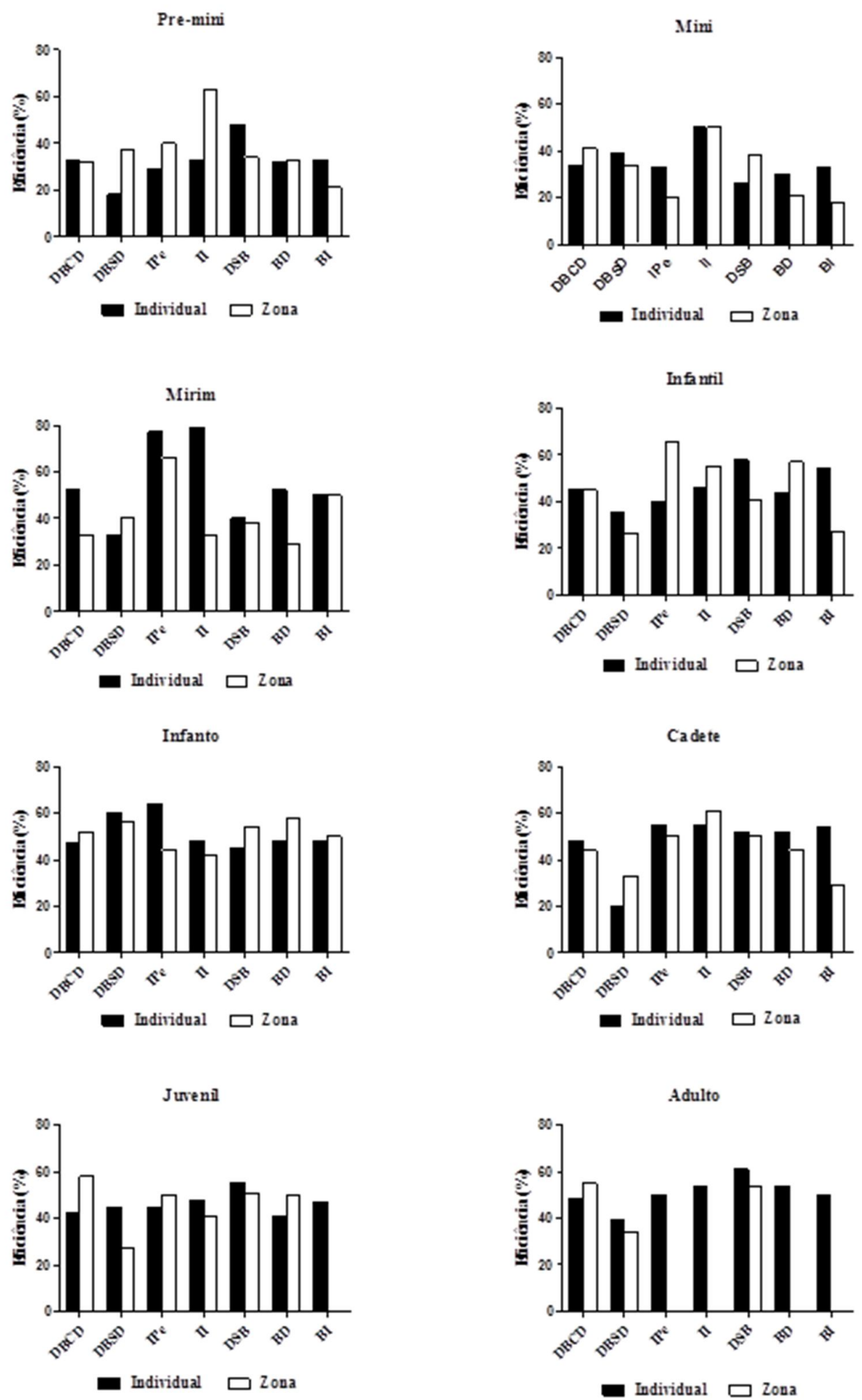

Figura 47: Eficiência das dinâmicas de criação de espaço (DCEs) (i.e., frequência de êxitos na finalização decorrente da realização da DCE e a frequência total de 
ocorrência da DCE) por faixa etária. Onde: DBCD: Desmarque com Bola com Drible; DBSD: Desmarque com Bola Sem Drible; IPe: Isolamento no Perímetro; II: Isolamento Interior; DSB: Desmarque sem Bola; BD: Bloqueio Direto; BI: Bloqueio Indireto.

\section{Equipes profissionais espanholas}

A modelagem dos desfechos possíveis da oposição ataque-defesa resultantes das ações previstas nas classes de DCEs e DPEs foi realizada através da decomposição dos processos, cuja estrutura principal encontra-se descrita na Figura 48. Optou-se por fixar como processos a serem decompostos as funções especificadas para os jogadores presentes em cada classe de DCE. O jogador com bola faz parte de todas as DCEs, ora na condição de protagonista do desequilíbrio (i.e., DBCD, DBSD, IPe, II, BD) ora como passador (i.e., DSB, BI). O receptor da bola faz parte do DSB. O receptor do bloqueio faz parte do BI, uma vez que o receptor do bloqueio em BD está contido no fluxo que descreve o jogador com bola. Finalemente, o bloqueador faz parte do BD e do BI. 


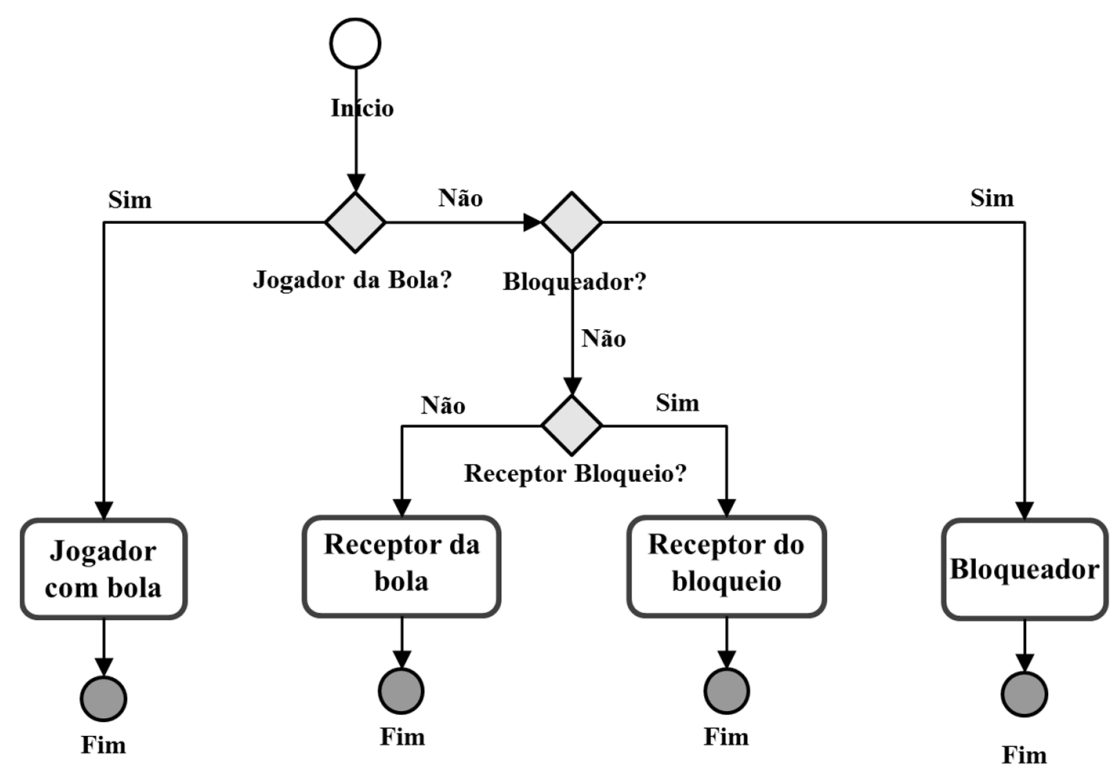

Figura 48: Estrutura de decomposição da interação DCE x DPE, a partir da ação dos seguintes jogadores atacantes: i) jogador com bola; ii) receptor do bloqueio; iii) receptor da bola; iv) bloqueador.

O processo do jogador com bola apresenta as possibilidades de resultado da interação descritas na Figura 49. O primeiro teste "Primeiro defensor?" verifica a presença de defensor imediato à ação ofensiva. Em caso afirmativo verifica-se se há finalização ("Finalização?”). Em caso negativo, há indicação de um evento intermediário. Ou seja, o ataque foi contido, o que pode levar a um novo ataque através de uma DCE subsequente ou a um reinício de toda a movimentação ofensiva. Em caso de finalização, o fluxo é direcionado para o processo "Finalização", comentado em detalhes na Figura 53. Caso o jogador com bola não seja defendido pelo primeiro defensor, testa-se a ocorrência de ajuda defensiva primária. O termo ajuda primária indica tratar-se de uma ajuda defensiva de um outro defensor presente no mesmo lance (e.g., em um BD, esta ajuda seria feita pelo defensor do bloqueador). Em caso afirmativo, testa-se a ocorrência de um ou mais passes extras. A expressão passe extra indica um passe em situação posterior a um desequilíbrio defensivo já realizado pelo ataque com o intuito de exacerba-lo. Tanto em caso de ocorrência do passe extra quando de não ocorrência, testa-se a realização de uma finalização. 
Se não há ajuda primária, é possível que haja ajuda secundária, ou seja, originada fora do lance da bola (e.g., defensor que se desloca a partir do lado oposto do setor defensivo). Se esta ajuda acontece, o mesmo caminho lógico da ajuda primária é percorrido, por tratar-se de uma ajuda da mesma maneira. Porém, se esta ajuda não acontece também, isto configura que o jogador com bola está livre. Testa-se então três possibilidades de encerramento da ação, através de finalização, violação ou reinício do ataque.

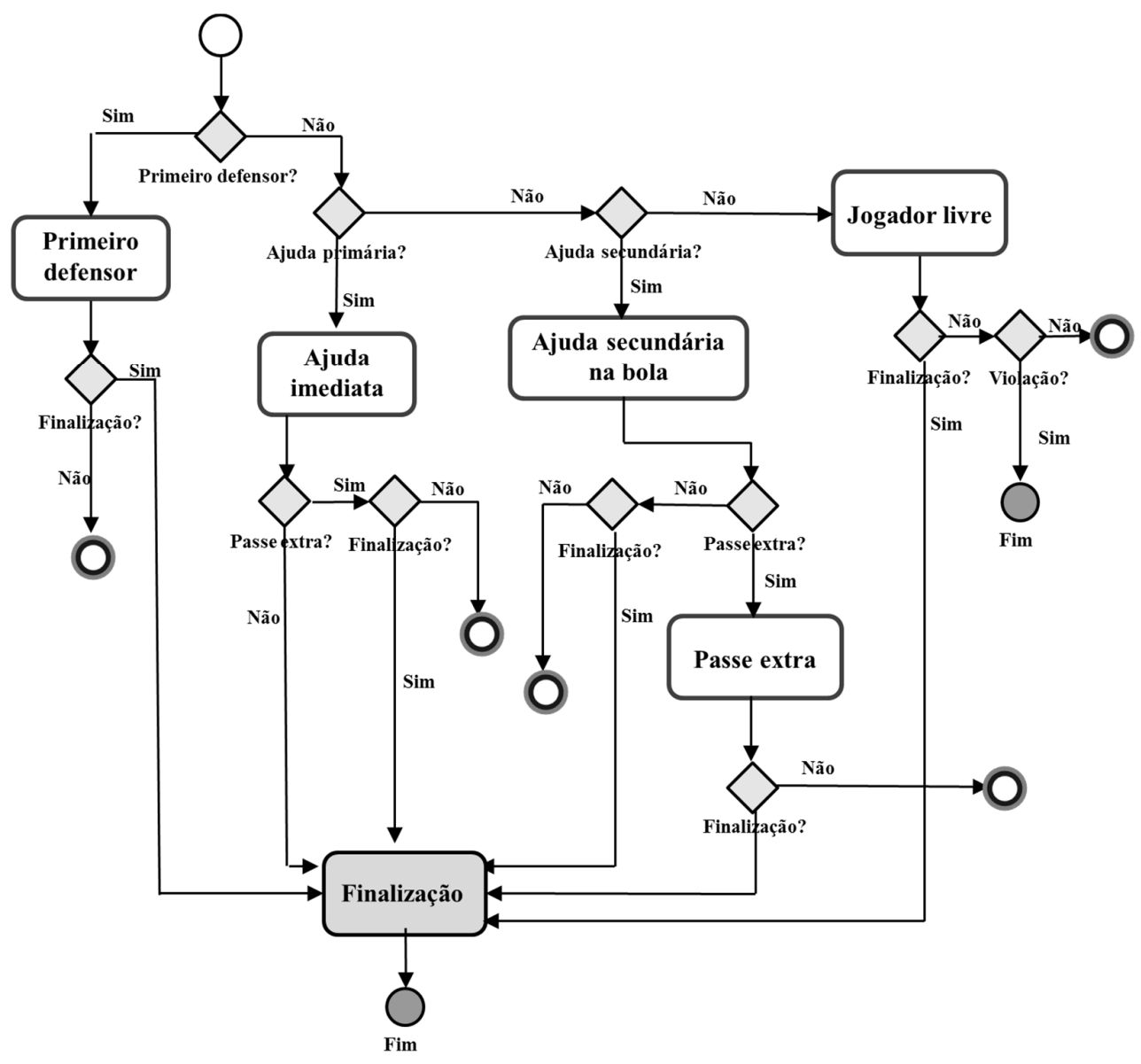

Figura 49: Descrição das alternativas de desfecho da oposição para o jogador com bola.

O processo do receptor da bola apresenta as possibilidades de resultado da interação descritas na Figura 50. Inicialmente verifica-se se há um defensor respectivo junto ao atacante receptor do passe (este contexto corresponde à execução de um DSB). Em caso afirmativo, testa-se se o jogador recebeu a bola. Em caso afirmativo, ocorre a 
sequência de testagens correpondentes ao desfecho por uma finalização. Em caso negativo, pode ocorrer uma ajuda secundária. Neste caso, o atacante que receberia a bola, não a recebe. Porém, a ajuda secundária pode ter liberado outro receptor na região exterior do ataque. Testa-se então a possibilidade de um passe nesta direção ("Passe exterior?’). Em caso negativo, o fluxo conduz a algum tipo de reinício da oposição, eventualmente, até mesmo com um novo DCE subsequente. Em caso afirmativo, mais um teste verifica a ocorrência de finalização.

Se o primeiro defensor não se faz presente (resposta negativa ao teste "Primeiro defensor?"), o fluxo testa o recebimento da bola. Em caso afirmativo, segue a testagem da "Ajuda primária?", "Passe extra"e "Finalização". Caso a ajuda primária não ocorra, verifica-se a ajuda secundária.

Finalmente, caso não haja o recebimento da bola, o fluxo é encerrado pois a oposição neste lance não foi consumada. 


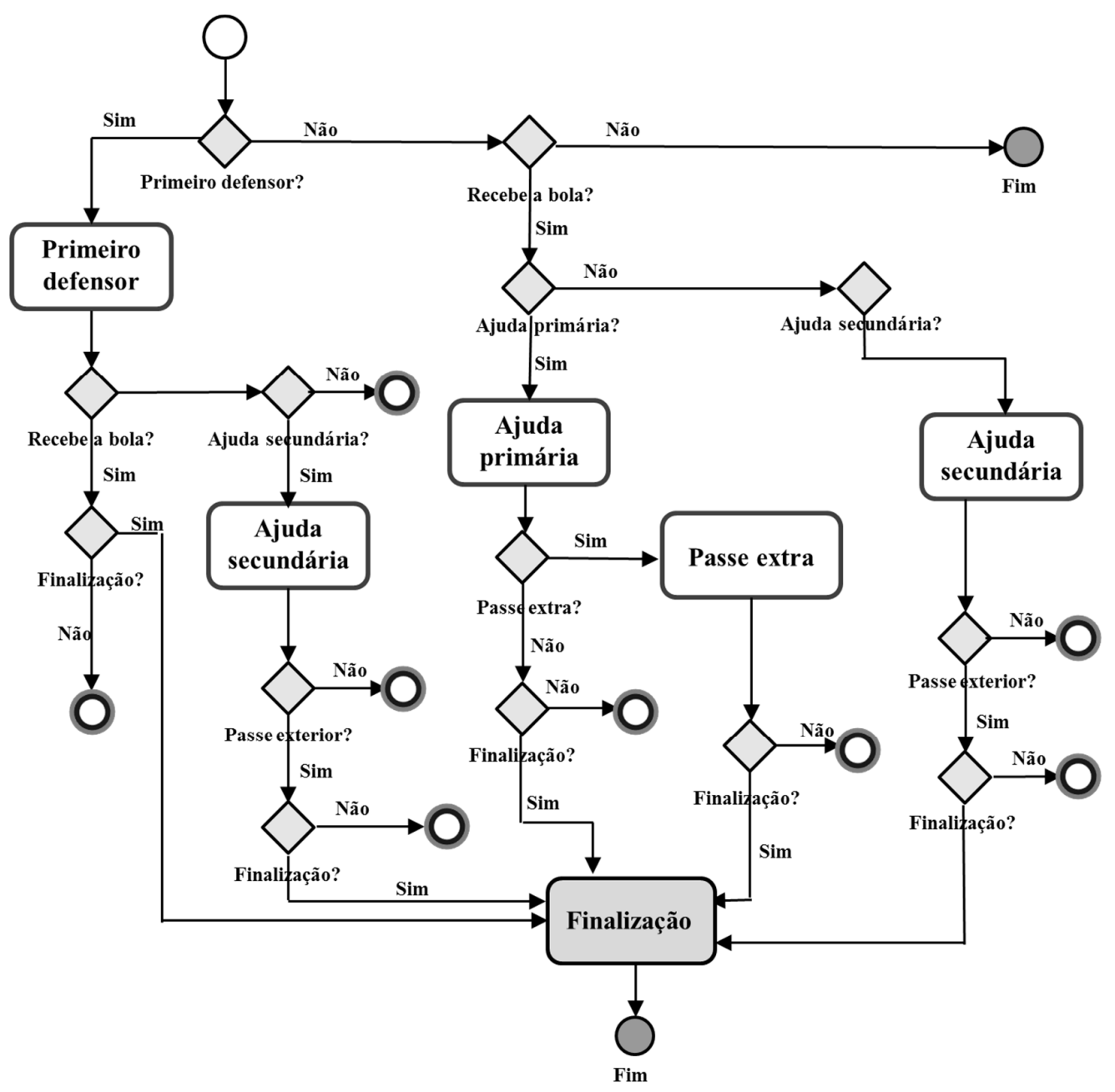

Figura 50: Descrição das alternativas de desfecho da oposição para o receptor da bola.

O processo do receptor do bloqueio apresenta as possibilidades de resultados da interação descritas na Figura 51. No início, testa-se a existência de um primeiro defensor ("Primeiro defensor?"). Em caso afirmativo, testa-se o recebimento da bola e a ocorrência de finalização. Caso contrário, novamente testa-se o recebimento da bola e, em caso afirmativo, verifica-se a ocorrência de ajuda do defensor do bloqueador, que caracteriza uma ajuda primária, pela proximidade deste defensor do receptor do bloqueio. Caso não ocorra a ajuda, testa-se a realização de passe extra ou o direcionamento para a finalização. De maneira semelhante, caso ocorra a ajuda primária, a realização de passes extras ou de uma finalização são também testados. $\mathrm{O}$ receptor do bloqueio pode ainda não receber a bola em virtude da maior eficácia da 
ajuda primária. Para contemplar esta possibilidade há o teste "Ajuda do defensor do bloqueador?" se a resposta ao teste "Recebe a bola?" for negativa. Se a ajuda primária ainda assim não ocrrer, pode haver ajuda secundária, a qual também é testada (“Ajuda secundária?"). Se a ajuda secundária acontece, verifica-se o encaminhamento da oposição para passes exteriores, em decorrência da rotação defensiva, e finalização. Se esta ajuda secundária não acontece, uma vez que o receptor do bloqueio não recebeu a bola, a defesa encontra-se organizada e o processo é encerrado pois necessariamente uma nova movimentação ofensiva deverá ser organizada.

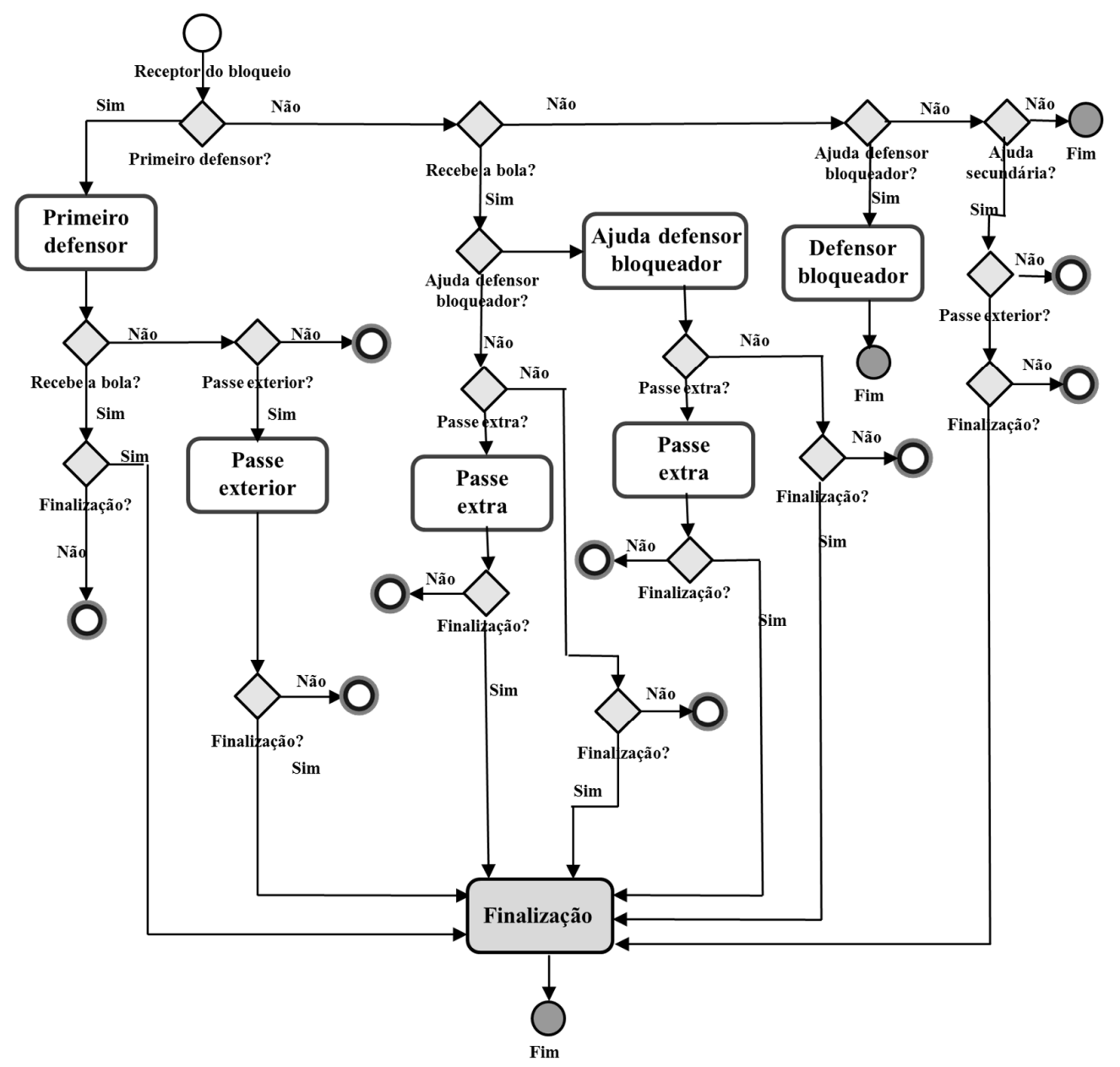

Figura 51: Descrição das alternativas de desfecho da oposição para o receptor do bloqueio. 
O processo do bloqueador apresenta as possibilidades de resultados da interação descritas na Figura 52. Incialmente verifica-se a existência de um defensor imediato no lance. Em caso afirmativo, testa-se o recebimento do passe e a possível continuação para a finalização. Caso a finalização não ocorra, verifica-se a ocorrência de ajuda secundária ("Ajuda secundária?"), que poderá levar a um passe exterior, à finalização ou reinício da movimentação. Caso não haja defesa imediata, verifica- se a ocorrência de ajuda primária ou secundária. Ainda, caso nenhuma das duas ocorra, o bloqueador estará livre podendo realizar a finalização ou reiniciar uma nova movimentação.

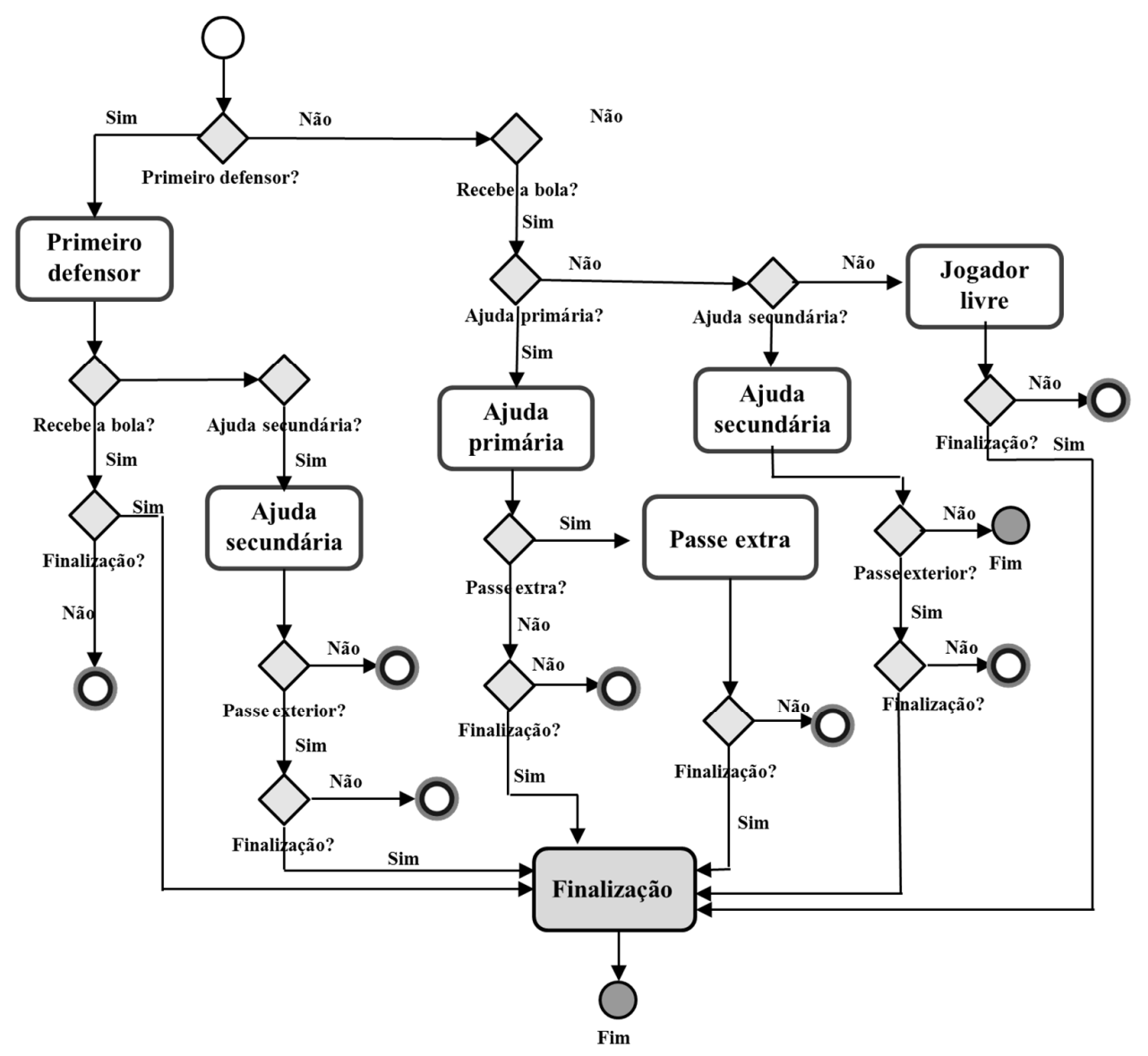

Figura 52: Descrição das alternativas de desfecho da oposição para o bloqueador.

O processo finalização apresentado nas figuras anteriores possui o conteúdo 
documentado na Figura 53. Assim, uma vez atingida a etapa de finalização, um dentre diversos desfechos pode ainda ocorrer.

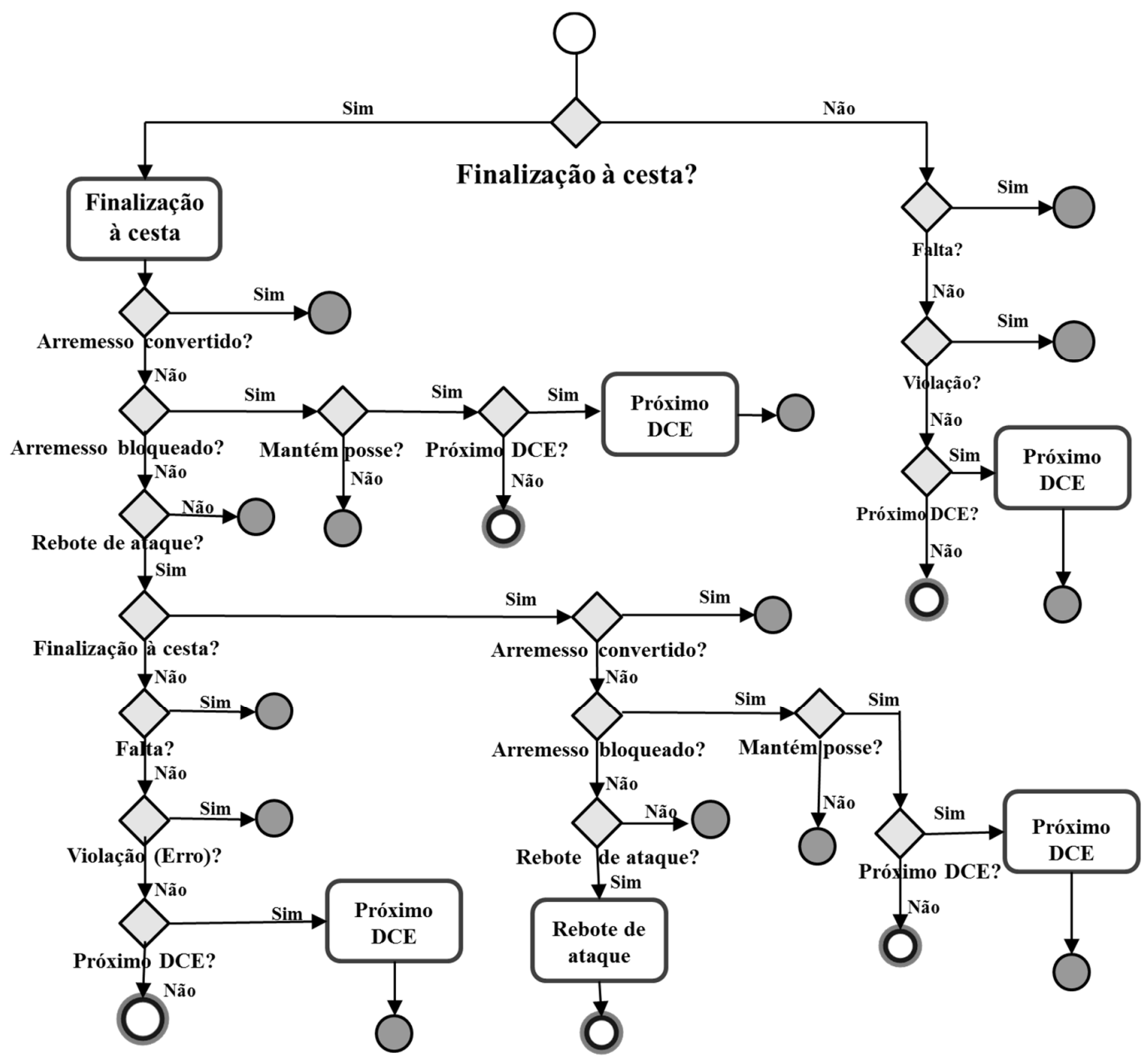

Figura 53: Descrição das alternativas de desfecho da oposição quanto às alternativas de finalização.

A modelagem dos possíveis desfechos da oposição complementou o suporte teórico fornecido pelas DCEs e DPEs para que a oposição pudessse ser analisada tanto em sua perspectiva ofensiva quanto defensiva. No contexto da amostra investigada (play-offs semifinal e final do campeontao espanhol de 2011), a Figura 54 apresenta a 
proporção de ataques posicionados, contra-ataques e posses nas quais o ataque não foi completado nos seis jogos analisados. Os ataques posicionais, conforme apresentado na Figura 54, predominaram de forma significativa em relação aos outros tipos de ataque

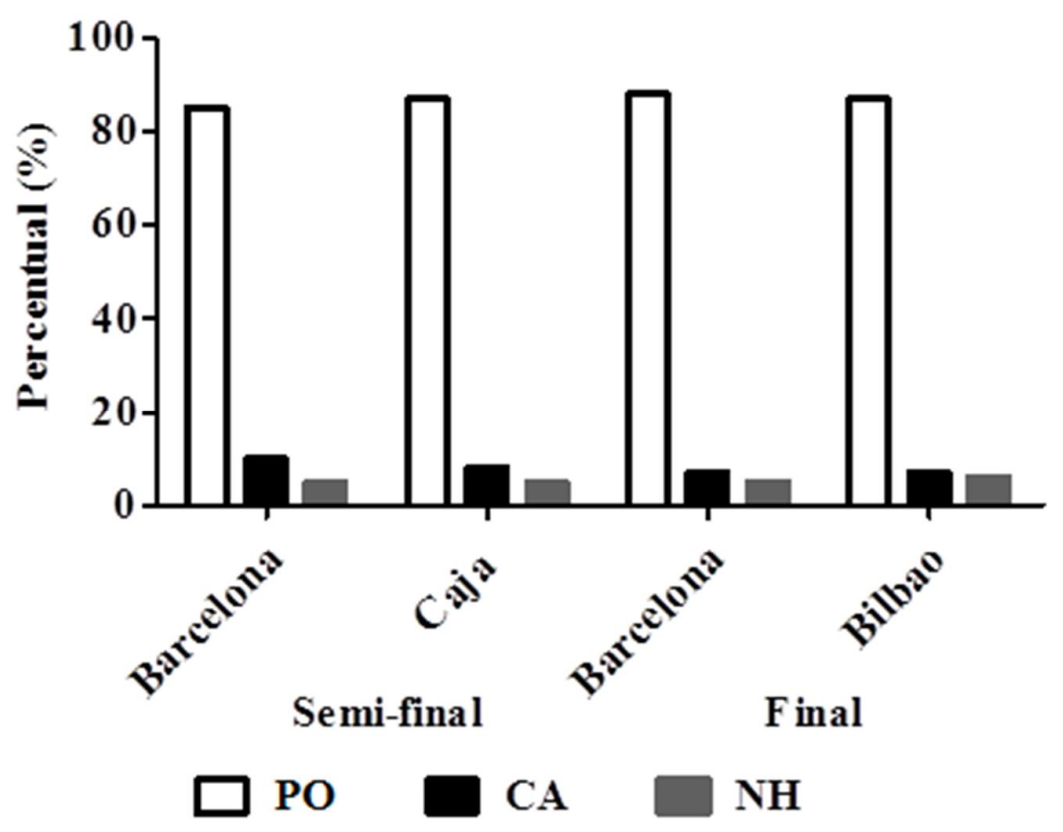

Figura 54: Percentual dos tipos de ataque (posicionado, contra-ataque, e não houve) para as equipes semi-finalistas e finalistas do campeonato espanhol masculino adulto -2011. Posicional - PO, contra-ataque - CA, e não houve ataque $-\mathrm{NH}$.

As equipes analisadas apresentaram as seguintes médias de posses de bola por partida: i) Barcelona, 74,7 posses de bola; ii) Caja Laboral, 75 posses de bola; e Bilbao Biskaia, 75 posses de bola. Dessa forma, cada uma das partidas disputadas teve, em média, aproximandamente 150 posses de bola. Porém, se analisadas as frequências de tentativas de ruptura do sistema defensivo adversário e, por consequência, a frequência de contenções defensivas, a média atingida foi de 267 ações por jogo. 
Para os ataques posicionais, a Figura 55 indica as DCEs utilizadas na três partidas semi-finais entre Barcelona e Caja Laboral. As DCEs são apresentadas conforme o detalhamento de cada classe nas possíveis orientações de deslocamento, pois a partir dos primeiros experimentos realizados, esta informação se mostrou valiosa para melhorar a compreensão da estratégia por detrás das ações realizadas.

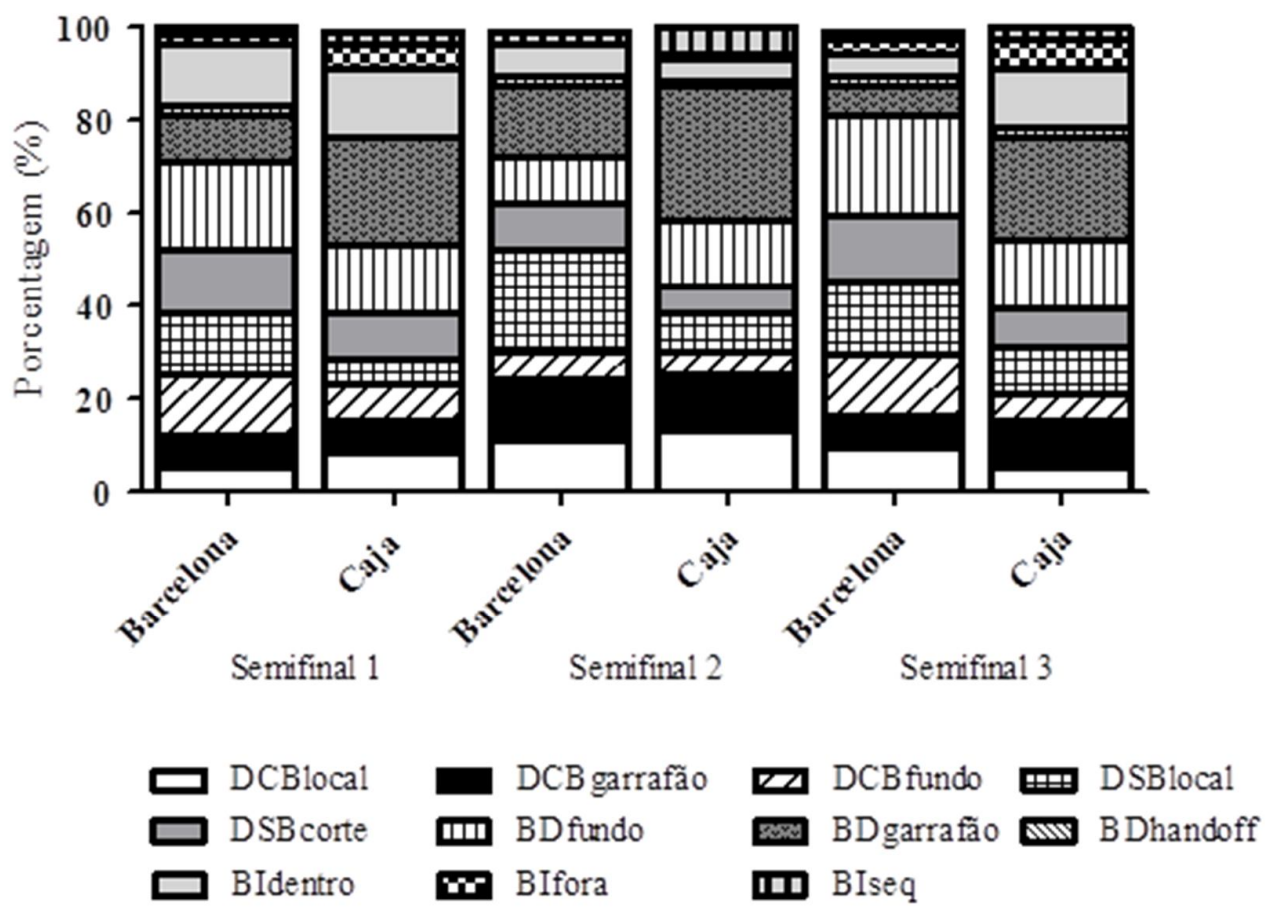

Figura 55: Percentual de ocorrência das dinâmicas de criação de espaço (DCEs) realizadas pelas equipes semifinalistas. Onde: DBCDlocal: Desmarque com Bola com Drible sem deslocamento; DCBgarrafão: Desmarque com Bola em direção ao garrafão; DCBfundo: Desmarque com Bola em direção à linha de fundo; DSBlocal: Desmarque sem Bola pela permanência em região sem marcação; DSBcorte: Desmarque sem Bola com corte para região sem defesa; Bdfundo: Bloqueio Direto orientado para o fundo da quadra; Bdgarrafão: Bloqueio Direto orientado para o garrafão; BDhandoff: Bloqueio Direto com passagem da bola de mão para mão; BIdentro: Bloqueio Indireto orientado para região interior da oposição; Bifora: Bloqueio Indireto orientado para região exterior da oposição; BIseq: Bloqueio Indireto sequencial. 
De forma complementar, para que se possa constatar não apenas as diferenças entre jogos consecutivos contra um mesmo adversário mas também o efeito da mudança do oponente, a Figura 56 indica as DCEs utilizadas na três partidas finais entre Barcelona e Bilbao Biskaia.

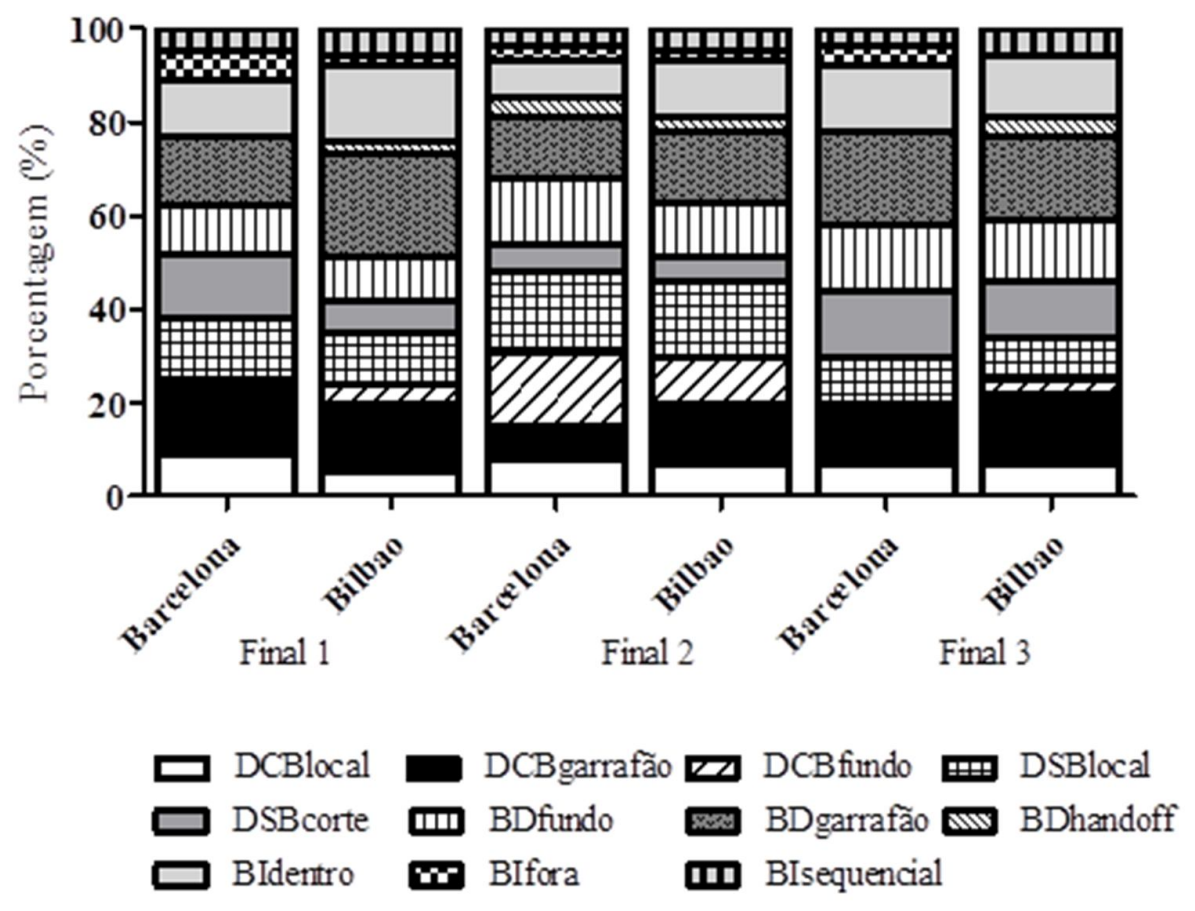

Figura 56: Percentual de ocorrência das dinâmicas de criação de espaço (DCEs) realizadas pelas equipes finalistas. Onde: DBCDlocal: Desmarque com Bola com Drible sem deslocamento; DCBgarrafão: Desmarque com Bola em direção ao garrafão; DCBfundo: Desmarque com Bola em direção à linha de fundo; DSBlocal: Desmarque sem Bola pela permanência em região sem marcação; DSBcorte: Desmarque sem Bola com corte para região sem defesa; Bdfundo: Bloqueio Direto orientado para o fundo da quadra; Bdgarrafão: Bloqueio Direto orientado para o garrafão; Bdhandoff: Bloqueio Direto com passagem da bola de mão para mão; Bidentro: Bloqueio Indireto orientado para região interior da oposição; 
Bifora: Bloqueio Indireto orientado para região exterior da oposição; Biseq: Bloqueio Indireto sequencial.

A Figuras 57 apresenta uma síntese do efeito da oposição nos padrões táticos apresentados pela equipe. Ela apresenta as três DCEs mais empregadas pela equipe do Barcelona nos dois primeiros jogos da semi-final, diante do Caja Laboral. O eixo Y da esquerda tem correspondência com a frequência absoluta (barra branca em todos os gráficos) da DCE de cada um dos gráficos. As demais barras possuem correspondência com a frequência relativa, cujo percentual está indicado no eixo Y da direita. $\mathrm{Na}$ progressão das cores utilizadas, o cinza mais claro indica a proporção de vezes em que a DCE do gráfico em questão foi empregada para iniciar uma tentativa de ruptura (i.e., primeiro DCE de uma eventual sequência, caso necessária). As demais colunas têm o foco no desfecho da oposição com o uso da referida DCE. A coluna denominada "Contenção" indica o percentual em que a DCE foi contida pela equipe adversária. Já a coluna "Novo DCE" indica a frequência relativa com que a execução da DCE levou à execução subsequente de um outro. Finalmente, a coluna negra indica a porcentagem de vezes em que a DCE gerou uma finalização. No eixo X encontram-se as DPEs que, somadas, corresponderam a 90\% dos comportamentos de contenção da ação ofensiva específica apresentada em cada gráfico. Na primeira semifinal as DCEs e DPEs mais frequentes foram: i) BD para o fundo com os defensor do receptor do bloqueio e do bloqueador reagindo, respectivamente, com a passagem por cima do bloqueio e afastando-se (Por cima e Afastado) ou passando por cima e realizando um rápido deslocamento na direção do receptor do bloqueio (Por cima e Mostrar); ii) DSB com corte e os defensores do atacante que realiza o deslocamento e faz o passe estando afastado e fora de posição em decorrência de ajudas defensivas (Afastado = Fora de posição) ou Próximo e Não orientado; iii) BI para dentro com um dos defensores realizando a saída por cima do bloqueio e o outro mantendo-se afastado ou sustentando a posição junto ao bloqueador (Por cima e Afastado ou Por cima e Sustentar), ou ainda realizando a saída pelo meio e o outro deslocando-se para inibir o deslocamento do jogador com bola (Pelo Meio e Mostrar).

Na segunda semifinal, as DCEs e DPEs mais frequentes foram: i) DCB garrafão, com o nome indicando a direção do deslocamento e as defesas mais frequentes sendo a 
Orientada ou encontrando-se fora de posição em decorrência das ajudas defensivas; ii) DSB local, encontrando-se a defesa do jogador que se desmarca, na maioria das vezes, fora de posição e o outro defensor induzindo o passador a um lado menos favorável para rotação corporal ou deslocamento (defesa Orientada); BD garrafão, com a defesa alternando entre algumas classes (Por Cima e Mostrar, Por Cima e Afastar e a Dobra no jogador com bola). 

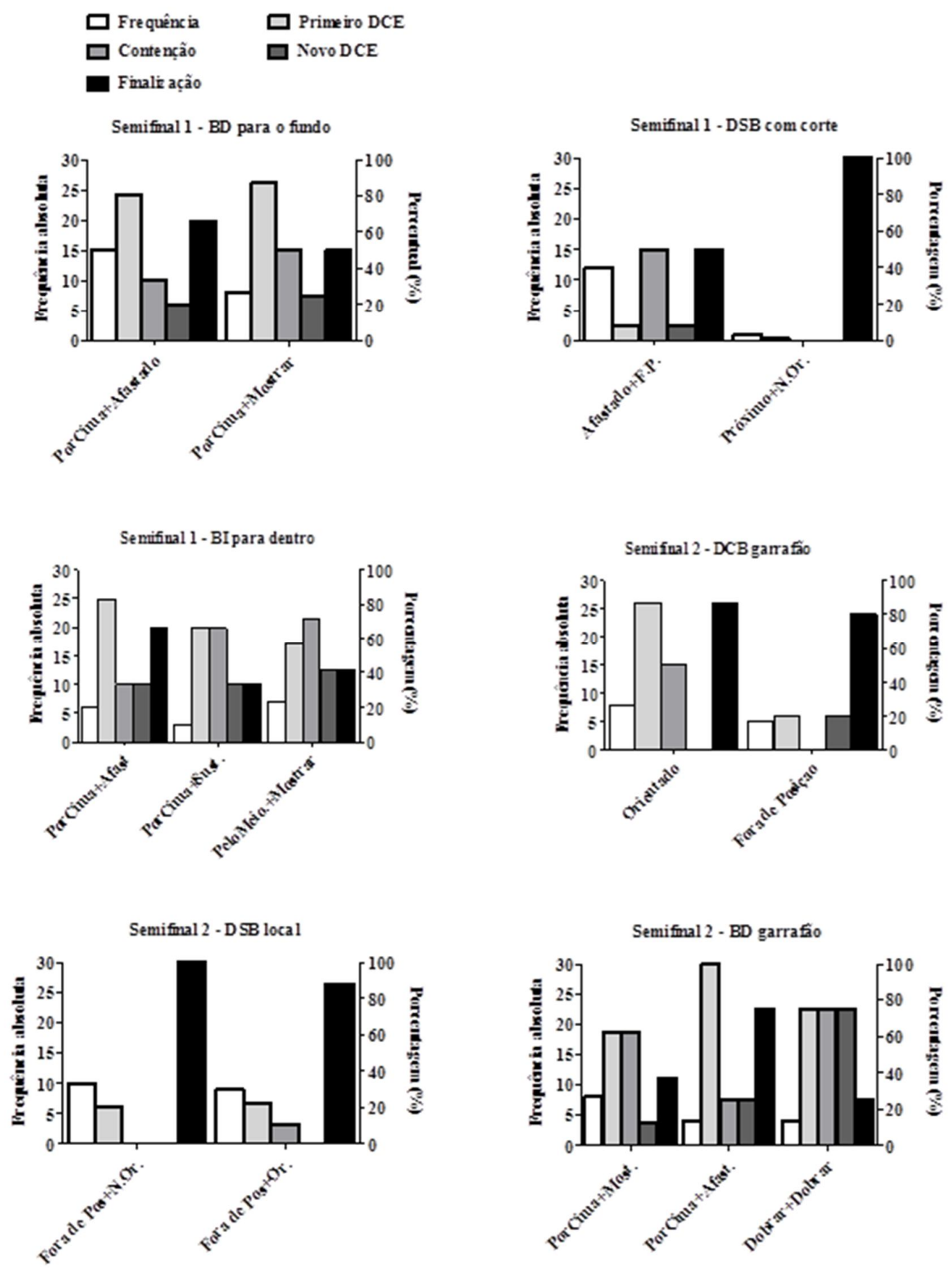

Figura 57: Frequência absoluta das três DCEs e respectivas DPEs mais recorrentes nos dois primeiros jogos semifinais do campeonato espanhol profissional de 2011 e percentual de sucesso no desfecho da oposição. 
Os comportamentos apresentados na terceira semifinal e no primeiro jogo da final são apresentados na Figura 58. No terceiro jogo semifinal observa-se: i) DSB com corte sendo defendido com as combinações Afastado e Fora de Posição, Afastado e Não orientado e Próximo e Não Orientado; ii) DSB local com as defesas Afastado e Fora de Posição e Afastado e Não Orientado; iii) BD para o fundo com as defesas Por Cima e Mostrar, Por Cima e Afastar, Dobra defensiva, Pelo Meio e Afastar. No primeiro jogo da final: i) DCB garrafão, sendo defendido com Por Cima e Mostrar, Dobra defensiva e Por Cima e Sustentar; ii) DSB com corte e as defesas Fora de Posição e Não Orientado, Foar de Posição e Orientado e Próximo e Orientado; iii) BD garrafão e as defesas Por Cima e Mostrar, Dobra defensiva, Por Cima e Sustentar. 

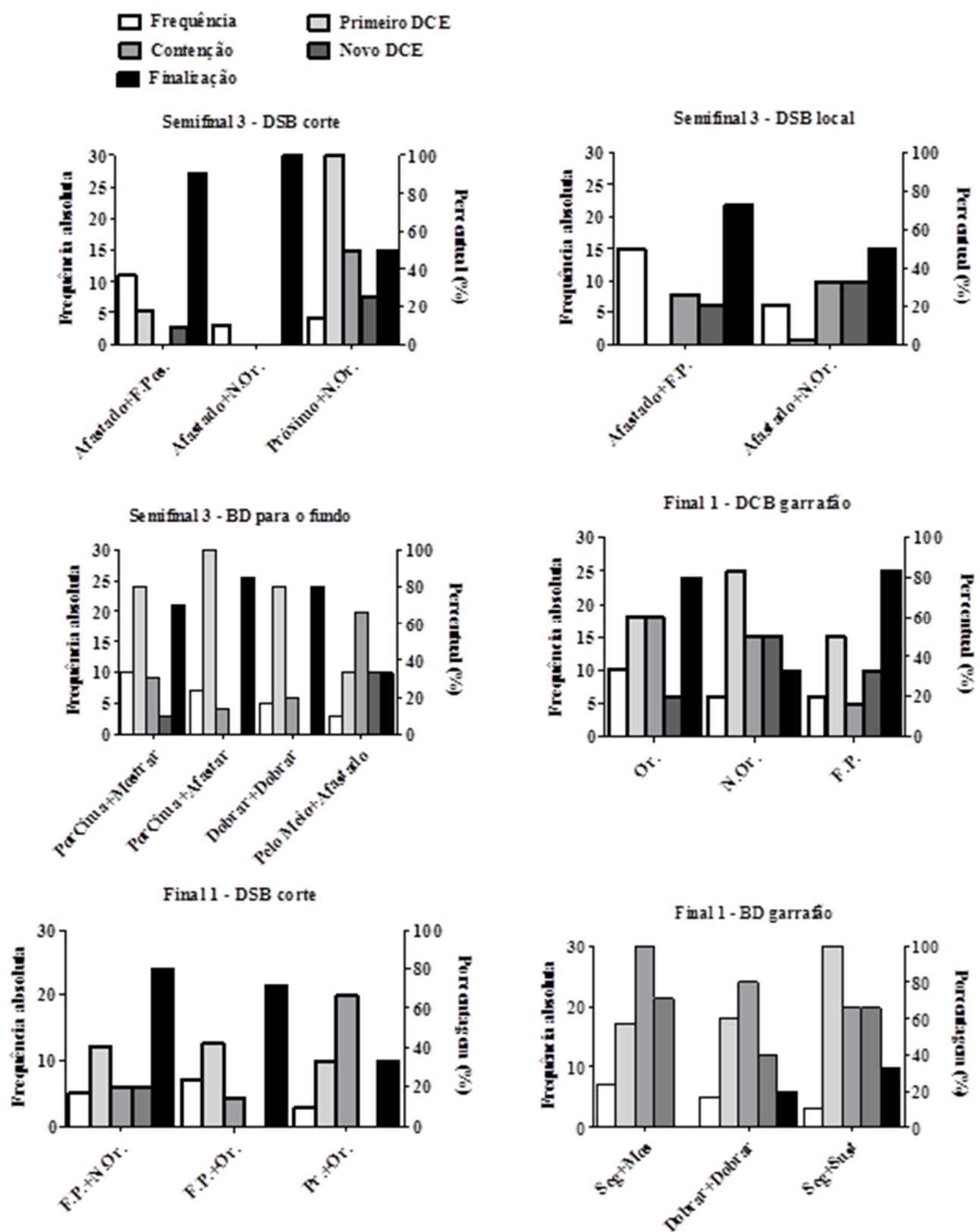

Figura 58: Frequência absoluta das três DCEs e respectivas DPEs mais recorrentes no terceiro jogo semifinal e primeiro jogo final do campeonato espanhol profissional de 2011 e percentual de sucesso no desfecho da oposição.

Por fim, os comportamentos apresentados nos dois jogos finais são apresentados na Figura 59 e descritos na sequência. No segundo jogo final foram mais frequentes: i) 
DCB para o fundo e a defesa Fora de Posição e Orientada; ii) DSB local e defesa Afastada e Não Orientada ou Afastada e Fora da Posição defensiva; iii) BD para o fundo, sendo defendido uma das Açõea combinadas Por Cima e Afastado, Por Cima e Mostrar, Troca defensiva. No último jogo, verificou-se: i) BD garrafão com a defesa Por Cima e Mostrar, Por Cima e Sustentar e Dobra defensiva; ii) BD para o fundo com as defesas Por Cima e Mostrar ou Por Cima e Sustentar; iii) Bi para dentro com a defesa Por Cima e Sustentar ou Troca defensiva. 


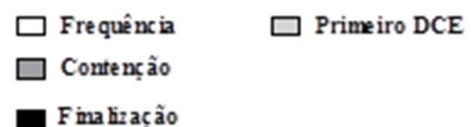

Final 2 - DCB para o fundo

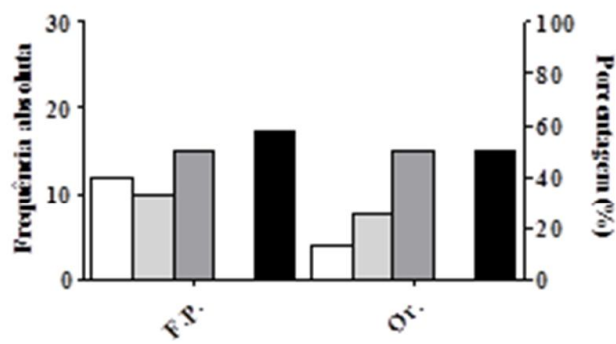

Final 2 - BD para o fundo

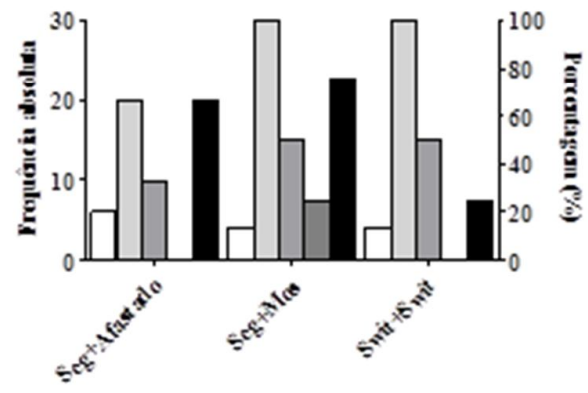

Final 3 - BD para o fundo

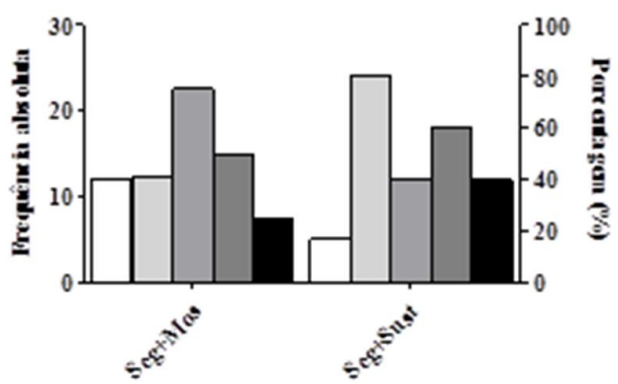

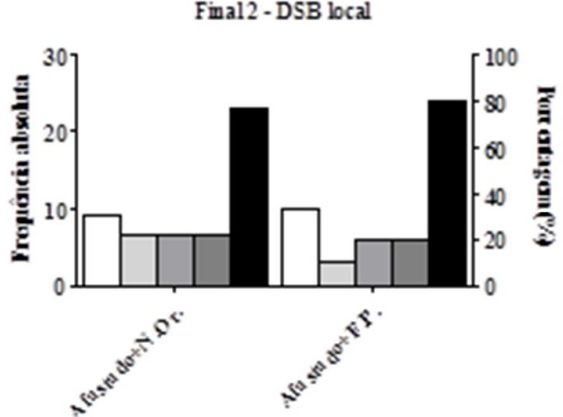

Final 3 - BD garrafáo

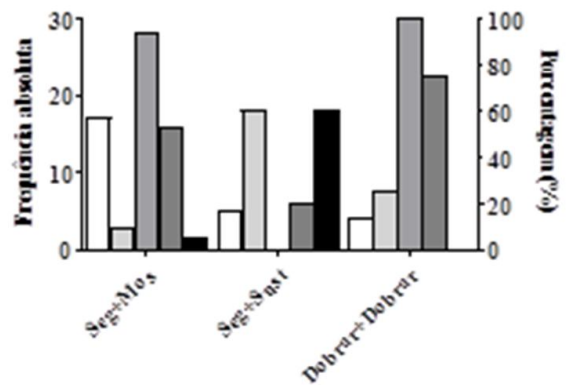

Fimal 3 - BI para dentro

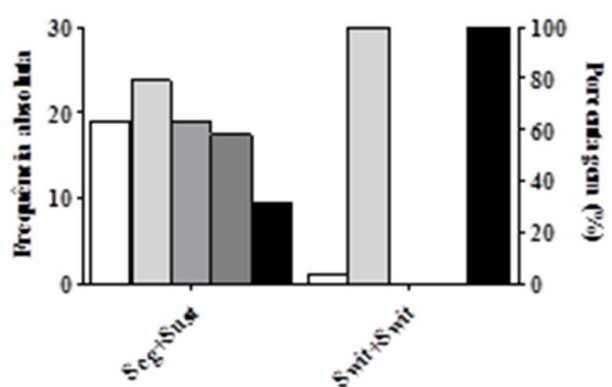

Figura 59: Frequência absoluta das três DCEs e respectivas DPEs mais recorrentes nos dois últimos jogos da final do campeonato espanhol profissional de $2011 \mathrm{e}$ percentual de sucesso no desfecho da oposição. 


\subsubsection{Discussão}

A principal contribuição da pesquisa apresentada neste capítulo foi a validação de classes de equivalência de dinâmicas de criação de espaço (DCEs) e dinâmicas de proteção do espaço (DPEs) no basquetebol. Estas classes contemplam os possíveis comportamentos ofensivos e defensivos realizados para, respectivamente, provocar uma ruptura na defesa ou proteger a própria meta. Os coeficientes do índice Kappa apresentaram valores elevados (acima de 0,70) para as análises intra- e interobservadores, indicando boa reprodutibilidade dos critérios definidores das classes de dinâmicas. Estas classes de dinâmicas suportam a aplicação da modelagem apresentada nos capítulos 3 e 4 deste trabalho a um ECI em particular, pois através delas é possível desenhar estratégias de equipes. Além disso, os experimentos com observação de equipes de basquetebol de diferentes níveis competitivos demonstrou a aplicação das DCEs e DPEs à análise da recorrência de padrões táticos no jogo de basquetebol.

Um requisito fundamental no processo de definição das classes de equivalência de DCEs e DPEs é que estas fossem exaustivas quanto à classificação dos comportamentos que ocorrem no jogo, sendo necessário contemplar todas as possibilidades de ações ofensivas para ruptura defensiva, assim como de ações defensivas para proteção da meta (NESTKE, 2004). Além disso, as classes deviam ser mutuamente desconexas, ou seja, comportamentos classificados em uma classe não deviam aparecer em outra. Por este motivo, o procedimento de validação procurou agrupar os comportamentos no menor número possível de classes, considerando que uma representação precisa do fenômeno devia conter seus atributos prinicipais (LAMES \& HANSEN, 2001). Para tanto, três atributos essenciais das ações foram considerados: i) o número de jogadores envolvidos; ii) a habilidade esportiva utilizada; iii) o contexto de decisão observado. O número de jogadores envolvidos define a complexidade da oposição (i.e., situações de 1x1, 2x2 e 3x3) e determina a habilidade esportiva que deve ser utilizada para a criação de espaço ou proteção da meta no jogo (i.e., penetrações com drible, desmarques sem bola, tipos de saídas de bloqueios diretos e indiretos, etc.). Finalmente, estas habilidades motoras podem ser executadas em contextos nos quais os 
jogadores não envolvidos com a ação na bola podem ou não ter uma decisão a priori de criar espaço para a ação dos jogadores na região da bola.

Para realizar a validação das classes de DCEs e DPEs, dois grupos de três treinadores profissionais de basquetebol (i.e., experts em basquetebol) realizaram a avaliação das versões iniciais das classes. Foi assim investigado em que medida os comportamentos observados (i.e., DCEs e DPEs) pelos experts refletiam a estrutura de classificação proposta. Em casos nos quais os treinadores profissionais discordaram na classificação das ações, as seguintes fontes de erros foram consideradas (JAMES, TAYLOR \& STANLEY, 2002): i) erro operacional: engano na digitação da classificação do evento; ii) erro de observação: falha na codificação do evento, que ocorre em situações nas quais se observa um evento e interpreta como sendo outro; e iii) erro de definição: falha na classificação de um evento, que ocorre em situações nas quais se observa um evento e o classifica de forma inapropriada devido à falta de objetividade na apresentação do critério de classificação. Se a divergência era causada pelas fontes "a" e "b" o erro era consertado. Entretanto, se era causado pela fonte "c" os critérios definidores do comportamento eram revisados enquanto a posse de bola em questão era revisitada. Este procedimento demonstrou ser efetivo para lidar com o problema semântico das definições operacionais e critérios definidores dos comportamentos observados (ODONOGHUE, 2007).

Finalmente, a reprodutibilidade intra- e inter-observadores foi acessada para determinar o grau de concordância na classificação das ações intra e inter-observadores, em três diferentes ocasiões (ODONOGHUE, 2007). Para este propósito, outro conjunto de avaliadores foi convidado para realizar a análise. Diferente da fase prévia de validação, não houve discussão sobre as classes entre os avaliadores até o término do período de análise. Os coeficientes Kappa apresentaram amplitudes de variação semelhantes e sugerem níveis elevados de concordância intra e inter-observadores para DCEs (intra: 0,76-0,85 e inter: 0,70-0,83) e para DPEs (intra: 0,92-0,97 e inter: 0,88 e 0,92), refletindo critérios bem definidos. Segundo O'DONOGHUE (2007), a compreensão dos eventos sendo classificados pelos avaliadores pode diferir entre potenciais observadores e, consequentemente, para a observação ser objetiva, os resultados devem ser independentes do observador. A similaridade dos valores de reprodutibilidade intra e inter-avaliadores indicam a ausência de erros sistemáticos de 
um mesmo avaliador ou entre avaliadores. O resultado do processo de validação indica que todos os comportamentos, ofensivos e defensivos, foram classificados em classes gerais de DCEs e DPEs, baseados em critérios precisos (JAMES, TAYLOR \& STANLEY, 2002).

Na classificação final, duas DCEs foram definidas para situações de 1x1, o DBCD e o DBSD. DBCD diferenciou-se de DBSD pelas consequências para os estados subsequentes da oposição quanto às decisões de cada jogador para reagir à ação empregada. Como o DBSD é muito restritivo em termos espaciais, a ação que o sucede é geralmente um rebote, que inclusive encontra-se em outra fase da oposição, a disputa. Por outro lado, um arremesso ou uma penetração com bola podem ocorrer após um DBCD, produzindo impacto distinto no processo de decisão das duas equipes e podendo levar à permanência da mesma fase da oposição caso não haja uma finalização na sua sequência. Ambos podem ocorrer mesmo em condições de elevada restrição espaçotemporal (i.e., pequenas distâncias e atrasos em relação ao defensor do jogador com bola). As classes defesivas definidas para a proteção de ações de DBCD e DBSD são as DPEs orientada ou neutra. A defesa "Orientada" indica um lado estratégicamente preferencial para o atacante realizar sua ação seguinte, em relação ao outro lado, cuja restrição é maior. Já no caso da defesa "Neutra” não há orientação preferencial.

Similar ao DBCD e ao DBSD mas em um contexto de decisão diferente são definidas as classes de IPe e II. No caso do DBCD e do DBSD, decisões individuais não são necessariamente coordenadas com outros jogadores da equipe. Por outro lado, IPe e II são caracterizados quando todos os demais jogadores agem a priori para criar espaço para que o jogador com bola atue com mais espaço e, ao mesmo tempo, tendo mais opções de linhas de passe. No IPe, os jogadores que não estão em posse da bola distanciam-se do jogador com bola, criando espaço na região do garrafão para a ação de penetração do jogador isolado. No II, depois da realização de um passe para o jogador no perímetro do garrafão, todos os demais jogadores movem-se para o perímetro para atrair os defensores, criando assim oportunidades de finalização na região interior ao garrafão. Nas situações em que a defesa dos jogadores conserva-se na região do garrafão para marcar o jogador com bola que ali se encontra, o espaço não defendido é criado no perímetro e um passe para um jogador livre pode ser realizado. O IPe é um caso particular de DBCD ou DBSD que ocorre no perímetro do ataque e com 
participação coletiva. Por este motivo, as DPEs para sua defesa são as mesmas já definidas paras as situações de 1x1. No caso do II, devido à região de sua ocorrência, há diferenças nas possibilidades defensivas. Dentre as DPEs definidas, caso haja bloqueio total da linha de passe, define-se a classe como defesa "Pela Frente". Se não houver impedimento para que o passe seja realizado, define-se como defesa "Por Trás". O primeiro caso pode ser adequado em situações nas quais o jogador possui grande potencial ofensivo e receber a bola possa impor risco tanto pela possibilidade de finalização quanto de distribuição da bola através de passes. No segundo caso, se o atacante não possui grande potencial ofensivo, pode ser mais adequado permitir a recepção da bola e esforçar-se para sustentar a defesa e impedir que ele progrida em direção à cesta. Situações intermediárias entre estes dois casos podem também ocorrer e as DPEs nestas situações foram classificadas como as defesas "3/4 Por Cima" ou "3/4 Por Baixo", indicando uma indução ao deslocamento do atacante em direção à linha de fundo (3/4 por cima) ou em direção ao meio da quadra (3/4 por baixo).

O DSB (e.g., cortes sem bola em direção à cesta) constitui uma ação com elevada demanda de coordenação inter-pessoal e pode ser precedida, por exemplo, de uma ação de IPe, que atrai a defesa do garrafão ou do perímetro, permitindo a penetração do jogador atacante e um passe para ele no espaço livre de defensores. Por tratar-se de uma jogada de $2 \times 2$, as classes defensivas incidem tanto sobre a defesa do passador quanto do jogador que realiza o corte. No caso do passador, a defesa novamente remete às possibilidades do $1 \times 1 \mathrm{e}$, por esse motivo, segue a mesma classificação já apresentada para DBCD e DBSD. Por outro lado, a defesa do jogador que realiza o desmarque pode ser classificada pelas DPEs "Próxima" ou "Afastada". Em função do plano estratégico coletivo da defesa, o defensor do jogador que realiza o corte pode encontrar-se muito próximo ao atacante, priorizando o impedimento da realização do corte ("Próxima"), ou mais distante, priorizando a ajuda defensiva de outras eventuais ações ofensivas (“Afastada”).

Duas classes ofensivas correspondem às ações de bloqueios, BD e BI, envolvendo situações de $2 \times 2$ e $3 \times 3$, respectivamente. Embora tanto BD quanto BI envolvam o fundamento do bloqueio, há diferenças entre eles. No primeiro são agrupadas todas as ações de bloqueios na bola (i.e., um jogador tem a posse da bola e o segundo jogador realiza um bloqueio para ele, caracterizando a ação de $2 \times 2$ ). Estas 
ações podem ocorrer em diferentes áreas da quadra ofensiva com potenciais situações de finalização sendo criadas para os dois jogadores atacantes envolvidos na ação. Após o bloqueio, o jogador com bola pode estar livre para finalizar ou o bloqueador pode receber um passe em condição ainda mais favorável. No caso do BI, este ocorre sempre que o jogador com bola realiza um passe para um companheiro de equipe, que por sua vez acaba de receber um bloqueio, caracterizando uma ação de 3x3. Estas ações dependem da coordenação entre os jogadores da equipe em pontos distantes da quadra entre si, pois o bloqueio pode ocorrer distante do jogador com bola, sendo ainda possível realizá-lo em diferentes direções (i.e., vertical, horizontal, diagonal). Portanto, o número de jogadores envolvidos e as diferenças nas opções de decisão em cada uma dessas classes são aspectos decisivos para diferenciar os comportamentos entre BD e BI. Na perspectiva defensiva, as alternativas de DPEs para o defensor do bloqueador se assemelham entre as duas classes, conforme explicado na sequência. "Sustentar" é uma opção para não dar alternativas de recepção da bola pelo bloqueador. No "Mostrar" o defensor do bloqueador faz um auxílio ao defensor do receptor do bloqueio, que restringe a possibilidade de progressão do atacante favorecido na ação. No "Abrir" o defensor do bloqueador da passagem para o defensor do bloqueado, e retorna para próximo do seu respectivo atacante. No "Afastar", o defendor do bloqueio permanece distante de seu atacante para judar na defesa do atacante receptor do bloqueio. $\mathrm{O}$ "Trocar" permite um ajuste rápido da defesa, embora possa ser desvantajoso em situações com diferenças grande de estatura entre atacantes e defensores após a troca. $\mathrm{O}$ "Dobrar" é a estratégia de maior imposição de pressão defensiva no receptor do bloqueio e, no caso do BI, ocorre apenas se este recebe a bola. No BI há ainda uma DPE que não ocorre no $\mathrm{BD}$, justamente pelo fato de no primeiro o bloqueio ocorrer para o jogador sem bola. Trata-se do "Colidir", do inglês bump, no qual o deslocamento do receptor do bloqueio é retardado devido à obstrução física não faltosa realizada pelo defensor do bloqueador.

Para o defensor do receptor do bloqueio não há diferenças nas alternativas defensivas entre BD e BI, sendo as seguintes DPEs definidas para sobrepor a obstrução impsta pelo bloqueio e seguir defendendo o atacante bloqueado. Na saída do bloqueio "Por Cima", o defensor é capaz de retomar a defesa doa atacante com mais rapidez, minimizando o efeito do bloqueio. "Pelo Meio" pode ocorrer para situações nas quais a 
saída "Por Cima" não foi possível por mérito ofensivo, ocorrendo um ajuste à situação. Ainda, pode ocorrer de maneira planejada quando o receptor do bloqueio tem bom potencial para penetração e baixo aproveitamento em arremessos e uma defesa mais recuada pode facilitar sua defesa. Nesta circunstância de pequeno risco em dar distância ao atacante que recebe o bloqueio é também possível a saída "Por Baixo", na qual as ações de penetração podem se rmais facilmente contidas. "Trocar" e "Dobrar", conforme mencionado para as DPEs da defesa do bloqueador, são classes que permitem, respectivamente, um ajuste rápido e uma intensificação da pressão no jogador com bola. "Inverter" é uma alternativa para inibir a consumação do bloqueio pois ao percebe-lo constituído, a partir do posicionamento do bloqueador, o defensor do suposto receptor altera seu posicionamento impedindo o deslocamento na direção do bloqueio. É uma ação que depende da coordenação precisa entre os dois defensores envolvidos para não haver a possibilidade de desmarcação do receptor do bloqueio na direção contrária, após o reposicionamento do seu defensor para evitar o bloqueio. Particularmente no BI, a defesa do passador segue a mesma classificação das demais ações de $1 \mathrm{x} 1$ já descritas. A coordenação entre ações dos defensores tem uma função muito importante e bem definida nas unidades estratégicas especificadas. É muito frequente, por exemplo, definições estratégicas que determinam para a defesa de um determinado atacante com bola, em situação de BD, a defesa "Por Cima" do bloqueio, enquanto o defensor do bloqueador realiza a ação de "Mostrar".

As classes de DCEs e DPEs acima descritas representam uma especificação fundamental para a formalização do conceito de estratégia pois materializam, no contexto de um ECI, as possibilidades estratégicas para desenho de estados a partir da estrutura formalizada no $\mathrm{EST}_{\mathrm{M}}$. São dinâmicas pertencentes a estas classes que se aplicam aos jogadores de cada unidade estratégica que, de forma orquestrada, geram a ação coletiva de uma equipe.

Em razão desta característica das DCEs e DPEs, estas classes caracterizam também importantes focos de análise do conteúdo da oposição em um jogo. Através delas é possível investigar a recorrência de comportamentos que informam sobre o perfil de determinadas sequências de estados da estratégia de uma equipe. Nesta perspectiva da análise do jogo, as DCEs e DPEs expandem diversos estudos sobre a análise de padrões táticos em jogos de basquetebol (CRUZ \& TAVARES, 1998; 
MEXAS, TSITSKARIS, KYRIAKOU \& GAREFIS, 2005; SILVA, 1998; TSAMOURTZIS, KARYPIDIS \& ATHANASIOU, 2005). Nestes estudos, há foco predominante sobre o ataque e não na oposição, e as dinâmicas coletivas analisadas (e.g., frequência de contra-ataques e ataques posicionados de uma equipe) não consideraram as interações individuais e grupais que levaram à ação coletiva. Porém, a constituição das DCEs e DPEs não é suficiente para a análise da oposição no jogo de basquetebol.

Para que as dinâmicas validadas possam ser utilizadas para análise de jogos é necessário modelar as interações entre elas e os possíveis desfechos dessas interações. Dessa forma, as consequências das interações entre as classes ofensivas e defensivas de dinâmicas podem ser quantificadas pois os resultados possíveis da oposição são conhecidos. Para tanto, a análise de dezenas de jogos de diferentes níveis competitivos deu suporte ao desenvolvimento de fluxos lógicos construídos com a linguagem formal MNPN que representam as interações da oposição e suas possibilidades de resultados. Nestes fluxos são contempladas também as ajudas primárias e secundárias, fornecendo suporte à compreensão da ação coletiva do ataque e da defesa.

Com as DCEs e DPEs validadas e as possibilidades de oposição modeladas, foi possível aplicar as classes de comportamentos ofensivos e defensivos à análise de jogos. Os contextos de disputa analisados foram: i) seleções nacionais que disputaram as quartas de final do torneio olímpico em 2008; ii) equipes paulistas do pré-mini ao adulto que disputaram o campeonato estadual em 2007; iii) equipes semi-finalistas e finalistas do campeonato espanhol profissional masculino de 2011. O resultado destas análises demonstrou maneiras pelas quais as DCEs e DPEs podem ser utilizadas por treinadores para aperfeiçoar suas estratégias, pelas informações obtidas nos jogos, além de identificar o perfil estratégico adversário.

\section{Seleções nacionais no torneio olímpico}

No contexto das seleções nacionais, a DCE com maior ocorrência foi o bloqueio direto (BD), tendo ocorrido em $34.8 \%$, o que corrobora a observação empírica de diversos treinadores de basquetebol. A predominância do BD é possivelmente relacionada à sua eficiência em propiciar espaço ao atacante com bola para finalizar de 
maneira simples, ou ainda pela possibilidade de algum outro atacante obter condição adequada de finalização em decorrência da rotação defensiva ocasionada pela ação do bloqueio. Para o atacante com bola, o BD cria espaço em um intervalo de tempo curto, porém suficiente muitas vezes para que jogadores de alto nível obtenham elevado índice de aproveitamento. Atualmente, defesas eficientes são capazes de reduzir o espaço e o tempo para a equipe atacante criar oportunidades de finalização (ANGEL, EVANGELOS \& ALBERTO, 2006), tornando o BD uma alternativa ofensiva útil e eficiente.

Outra DCE com elevada recorrência entre as equipes de alto nível foi o isolamento interior (II). Sua proximidade da cesta aumenta o potencial de finalização e a possibilidade do jogador com bola sofrer uma falta que resulte em lances livres. O perfil ofensivo de alguns jogadores influencia o aumento de ocorrência dessa dinâmica na estratégia da equipe. Este parece ser o caso da China, por causa do seu pivô dominante no torneio analisado. A análise do mapa de correspondência simétrico indica que II esta muito próximo à China (Figura 43). De maneira semelhante, o IPe está muito próximo aos EUA, indicando a recorrência desta estratégia que favorece o jogo de 1x1, no qual os americanos tradicionalmente se destacam. É também interessante constatar que a Argentina foi a seleção nacional que ficou localizada com maior prximidade à intersecção dos eixos do mapa de correspondência (Figura 6), indicando a menor contribuição para constituição dos eixos do mapa e, consequentemente, a distribuição mais equilibrada de ocorrência de DCEs.

As duas equipes que disputaram a medalha de ouro, Espanha e Estados Unidos, apresentaram diferentes ênfases de DPEs em suas estratégias (Figura 42). Os Estados Unidos basearam seu jogo em IPe, DBCD e BD, enquanto a Espanha apresentou um padrão mais homegêneo entre II, BD e BI, ainda assim com uma prevalência de BI. É possível que a frequência elevada de ações individuais (DBCD) ou coletivas mas voltadas para auxiliar um jogador em particular (IPe) dos Estados Unidos seja consequência do grande potencial físico e técnico de seus jogadores, que permite tirar vantagem de pequenas janelas temporais para realizar a finalização. Em comparação, a Espanha pode ter tirado vantagem das ações de bloqueios indiretos (BIs) pois esta classe envolve três jogadores e permite maior diversidade de comportamentos depois que a técnica de bloqueio é executada. Além disso, a elevada recorrência de ações de II e Bd é 
compatível com a concepção de jogo espanhola de múltiplas soluções para a ação ofensiva.

Equipes paulistas do pré-mini ao adulto

Quando analisadas as categorias de base, o principal resultado da análise das equipes de diferentes faixas etárias do basquetebol paulista foi que todas elas apresentaram perfil semelhante de atuação, quanto à frequência de DCEs utilizadas, sua eficiência e grau de cooperação. Apenas o tipo de defesa pareceu modular as recorrências de DCEs, verificando-se predomínio de Desmarque com Bola com Drible e Bloqueio Direto contra defesa individual e Desmarque com Bola com Drible e Desmarque sem Bola contra defesa por zona. A eficiência das DCEs também apresentou padrão homogêneo entre as faixas etárias.

Já o tipo de defesa praticado nos ataques posicionados sofreu alterações em função da faixa etária. Verificou-se predomínio da defesa por zona entre os mais jovens (pré-mini e mini, $\mathrm{p}<0,05)$ e predomínio da defesa individual entre os mais velhos (juvenil e adulto, $\mathrm{p}<0,05$ ), sendo que o aumento da participação da defesa individual é gradual ao longo das faixas etárias (FIGURA 2). Estes dois tipos de defesa possuem diferenças em suas concepções teóricas, assim como em suas dinâmicas, que implicam na defesa de um jogador específico (defesa individual) ou zona da quadra específica (defesa por zona). É possível que um motivo para o predomínio de defesa por zona entre os mais jovens seja a vantagem estratégica adquirida ao concentrar os defensores em regiões mais próximas à cesta, forçando o ataque a finalizar a partir de regiões mais distantes, nas quais a eficiência é menor para indivíduos mais jovens conforme demonstrado por (OKAZAKI, RODACKI, DEZAN \& SARRAF, 2006).

Para cada um dos tipos de defesa(i.e., individual ou por zona), não foram verificadas diferenças nas frequências de DCEs entre as faixas etárias. Estes resultados indicam que, embora a amostra investigada tenha sido composta por todo o espectro de níveis de experiência possível (i.e. pré-mini ao adulto), as ações preferenciais utilizadas para vencer a oposição e gerar finalização foram semelhantes, quando considerado um tipo de defesa em particular. Decorre desta constatação a possível existência de DCEs preferenciais em detrimento de outras. As DCEs preferenciais para ataques contra 
defesa individual (Desmarque com Bola com Drible e Bloqueio Direto) corroboram os resultados encontrados no torneio olímpico de 2008, descrito acima, assim como com os resultados de Remmert (2003), cuja amostra apresentou predominância dos mesmos tipos de ações nas tentativas de ruptura da defesa. Contra defesa por zona, em nossos resultados o Desmarque com Bola se mantém como uma ação predominante, além do Desmarque sem Bola. Uma vez que defesas por zona protegem áreas específicas da quadra, a ocupação de espaços vazios da quadra pelos atacantes faz com que o Desmarque sem Bola seja uma ação recorrente na tentativa de ruptura do sistema defensivo. Entretanto, contra nenhum dos tipos de defesa as DCEs mais utilizadas apresentaram eficiência superior às demais DCEs (Figura 47). Esta evidência indica uma possível incoerência nas instâncias de decisão estratégica e tática das equipes, quanto à escolha e execução de um conjunto restrito de ações ofensivas de ruptura defensiva que não resultaram em maior eficiência que as outras DCEs menos utilizadas.

É possível associar a utilização preferencial de certas DCEs a algumas características da oposição. No caso da predominância de Desmarque com Bola com Drible em relação a todas as demais DCEs verificadas do pré-mini ao infantil contra defesa individual e do pré-mini ao adulto contra defesa zona, com exceção feita ao Desmarque sem Bola, dois fatores podem ser relacionados. Nas faixas etárias mais novas a defesa possui maior fragilidade, sendo frequente que os jogadores apresentem falta de condicionamento para manter uma boa postura defensiva e movimentar-se com velocidade nos deslocamentos laterais. Além disso, nestas idades a tática coletiva defensiva (i.e. ajudas e rotações) costuma ser simplificada aumentando as chances de sucesso de ações ofensivas individuais. Ainda, nestas idades é esperado que os atacantes tenham menor capacidade de coordenar suas ações conjuntas, o que pode contribuir para explicar a menor frequência de bloqueios e isolamentos, recorrendo-se então a ações individuais por meio do Desmarque com Bola com Drible. É comum também que certas equipes possuam jogadores mais hábeis que os demais, os quais recorrem ao Desmarque com Bola com Drible para finalizar o ataque. Este argumento pode contribuir inclusive para explicar porque o Desmarque com Bola com Drible, embora tenha diminuído com o aumento da idade, continuou como uma das DCEs mais utilizadas até a categoria adulta, correspondendo a 51\% no pré-mini, $39 \%$ no infantil e 
$27 \%$ no adulto contra defesa individual e $47 \%$ no pré-mini, $47 \%$ no infantil e $32 \%$ no adulto contra defesa por zona.

A frequência do Bloqueio Direto contra defesa individual pode ser explicada por argumento semelhante, pois se trata de uma DCE que favorece a ação de um jogador habilidoso em posse de bola que se vale de um bloqueio (i.e. obstrução do deslocamento de seu defensor realizado por um de seus companheiros de equipe) para ensejar uma boa situação de finalização para si ou para o colega que efetuou o bloqueio. O perfil crescente, embora não significantemente diferente de sua utilização - pré-mini: 13\%, infantil: $21 \%$ e adulto: $29 \%$ - indica a necessidade de maior elaboração do ataque em relação à ação de Desmarque com Bola com Drible para vencer a oposição defensiva, mas também uma ênfase na utilização do potencial ofensivo dos melhores jogadores, já que DCEs envolvendo a coordenação de mais jogadores (e.g., Bloqueio Indireto, Isolamento Interior, Isolamento no Perímetro) não foram tão frequentes quanto o Bloqueio Direto, em especial em categorias mais velhas. A elevada frequência de utilização do Bloqueio Direto em equipes de diferentes idades já havia sido verificada em outros estudos (REFOYO, DOMINGUEZ, SAMPEDRO \& DEL CAMPO, 2009; ROMERO, 2010).

Nossos resultados demonstram uma pequena tendência ao aumento da diversidade das DCEs com o aumento da faixa etária, o que pode refletir a aprendizagem de outras formas de atuar. Assim, o prolongamento do tempo de prática pode, mesmo que de forma não planejada e controlada, contribuir para a diversificação das ações de jogo. Esta diversificação parece ser positiva, pois implica em maior imprevisibilidade da ação ofensiva da equipe frente ao adversário.

A ação de Isolamento no Perímetro apresentou no mirim os maiores valores de eficiência dentre as DCEs em todas as idades (contra defesa individual e zona, respectivamente: $77 \%$ e 66\%). Já o Isolamento Interior apresentou comportamento semelhante contra defesa individual, com o índice de $79 \%$ de eficiência, mas não contra defesa zona, cuja eficiência foi de $33 \%$. O resultado inferior obtido contra defesa zona corrobora com a perspectiva de utilização desta defesa para limitar as possibilidades de ações no interior do garrafão, que é o objetivo do Isolamento Interior. De modo geral, os resultados de eficiência nos isolamentos podem ter relação com a presença de um ou mais jogadores com alta produtividade nas ações de 1x1 no interior do garrafão ou no 
perímetro, gerando mais ações de isolamento por parte da equipe. Porém, nem todas as equipes possuem jogadores com estas características, assim como defesas elaboradas podem ter melhores condições de neutralizá-las. Isso pode explicar a variação da eficiência encontrada para essas DCEs nas demais idades.

É possível concluir que há homogeneidade nas ações ofensivas de ruptura do sistema defensivo entre as diferentes faixas etárias, sendo semelhantes tanto as frequências das DCEs, quanto o aproveitamento das oportunidades de finalização decorrentes. Estes resultados contrariam a expectativa de aumento da complexidade e diversificação das ações com o aumento da experiência competitiva dos jogadores.

\section{Equipes profissionais adultas espanholas}

Os resultados desta aplicação das DCEs e das DPEs confirmam a relevância da informação sobre a oposição, ao invés de uma única das equipes, para o entendiemtno do jogo. Isto torna-se possível com a definição das DCEs, DPEs, a modelagem dos desfechos da oposição. Embora ainda necessite desenvolver o conhecimento sobre desenhos experimentais que contribuam para o aprofundamento do conhecimento sobre o jogo.

Com a análise da série de play-offs foi possível constatar recorrências de padrões ofensivos tais como os bloqueios diretos e os desmarques sem bola, que já haviam sido verificados nos outros estudos precedentes, mas também os padrões defensivos para conter estas ações, que parecem também serem recorrentes nos planos estratégicos de diferentes equipes. Por exemplo, é o que ocorre em resposta ao BD, para o qual as duas equipes que enfrentaram o Barcelona utilizaram com frequência a saída Por Cima e o movimento de Mostrar ou Afastar do bloqueador.

$\mathrm{O} \mathrm{EST}_{\mathrm{M}}$ e o modelo da dinâmica do jogo fornecem os delimitadores para a elaboração de uma estratégia adequada às necessidades de uma equipe de um ECI e, de maneira complementar, as DCEs e DPEs informam o conteúdo a ser especificado para as ações dos jogadores em suas respectivas unidades estratégicas. As DCEs e DPEs impactam também na análise dos jogos e elaboração das sessões de treinamento pois assim como em relação ao desenho de estratégias, as classes de dinâmicas são os elementos constitutivos dos conteúdos analisados e treinados. 
A maneira usual de se obter indicadores de desempenho para análise do jogo não considera as interações dinâmicas nas quais estes ocorrem (LAMES \& MCGARRY, 2007). As análises são focadas nas frequências relativas das ações de jogo, o que não dá suporte à compreensão do contexto sequencial do jogo (HUGHES \& BARTLETT, 2002; MCGARRY et al., 2002). Por outro lado, as DCEs e as DPEs, em conjunto com a modelagem dos possíveis desfechos da oposição, fornecem critérios objetivos para a avaliação da natureza sequencial dos eventos de ruptura e as formas de contê-los, que podem assim conduzir a uma oportunidade de finalização ou à retomada da posse de bola. 


\section{DISCUSSÃO GERAL}

A contribuição fundamental do presente estudo foi apresentar uma abordagem formal para o entendimento do jogo em ECIs, que permite a testagem e aperfeiçoamento dos seus elementos estruturais por meio de experimentos quantitativos. Os principais conceitos formalizados foram a estrutura dinâmica da estratégia e da oposição, além das classes de comportamentos ofensivos e defensivos através das quais uma estratégia pode ser especificada e a oposição é realizada. As estruturas dinâmicas da estratégia e da oposição são generalizáveis para qualquer ECI, já as classes de comportamento, embora se trate de um conceito presente em todos os ECIs, adquire relevância prática quando instanciado a um esporte em particular. O modelo proposto constitui uma contribuição original à teoria dos esportes coletivos de invasão, tanto pelos avanços imediatos no entendimento das características estruturais desses esportes quanto pelos possíveis desdobramentos tecnológicos, que podem igualmente contribuir no processo de ensino-aprendizado nos mais diversos níveis competitivos.

Os conceitos aqui formalizados até então haviam sido estudados por diferentes autores, porém com dois tipos de limitação principais. Primeiro, há diversos estudos experimentais que foram capazes de isolar e investigar com profundidade as propriedades de um aspecto específico dos ECIs porém, dado o caráter analítico dessas investigações, as implicações para uma teoria sobre os ECIs não podem ser bem localizadas (BORRIE, JONSSON \& MAGNUSSON, 2002; DUMANGANE, ROSATI \& VOLOSSOVITCH, 2009; PASSOS et al., 2008; PASSOS et al., 2011; SEABRA \& DANTAS, 2006). Segundo, estudos mais abrangentes, voltados para o entendimento do fenômeno em seus aspectos mais globais, não foram capazes de formalizar os conceitos apresentados de maneira a dar suporte a estudos experimentais que sejam capazes de testar empiricamente as idéias concebidas (GREHAIGNE \& GODBOUT, 1995; LEBED, 2007; MCPHERSON, 1999a 990; MCPHERSON, 1999b; MCPHERSON, 2000). Com isso o presente estudo se constitui em uma abordagem original e com múltiplos desdobramentos para a pedagogia dos ECIs.

A formalização das especificações estratégicas em um estado e sua representação por meio de um grafo são incomuns no contexto esportivo atual e tornaram-se possíveis com a definição do $\mathrm{EST}_{\mathrm{M}}$. A maneira convencional de se 
apresentar uma estratégia formulada é por meio de sequências de diagramas de cada movimentação planejada, dissociadas entre si (e.g., jogada 1, jogada 2 , jogada 3 , etc). A apresentação de todas as opções planejadas de maneira integrada em um grafo, conforme proposto neste trabalho, além da representação integrada permite uma decomposição estruturada de seus elementos. A estratégia pode ser particionada no grafo através de sub-grafos relativos às fases do jogo. Dentro de cada sub-grafo ainda, as sequências de estados podem ser orientadas para situações específicas da oposição. Por exemplo, no sub-grafo do ataque, há sequências para atuar contra defesa zona ou individual. Finalmente, estas sequências podem ser interpretadas a partir dos estados e das regras de ação contidas em cada um deles. Esta estrutura suporta, em termos científicos, análises da complexidade das estratégias e comparações entre elas, por meio de metodologias bem consolidadas na teoria de grafos. Na prática profissional, a visualização de sua topologia permite ao treinador interpretar seu planejamento de maneira global e analisar possíveis deficiências quanto a sequências de estados com um menor número de variações ou regiões do grafo menos densas, indicando uma parte mais vulnerável da estratégia e a provável necessidade de planejar especificações adicionais para lidar com certas situações da oposição.

Outra implicação para a atividade do treinador se verifica no processo de treinamento. Isso porque a aprendizagem objetivada com o treinamento pode se tornar mais eficiente se os conteúdos a serem ensinados forem definidos com maior precisão. Além disso, em decorrência da lógica de decomposição top-down da estratégia, o nível de resolução do objetivo de uma sessão de treinamento pode ser ajustado sem perda de precisão. É possível elaborar o conteúdo do treinamento com foco no aprendizado da concatenação das regras de ação dos jogadores em uma breve sequência de estados importantes. Ou, com menor resolução, pode-se aperfeiçoar um conjunto amplo de sequências de estados destinados a alguma situação (e.g., múltiplas movimentações para uma defesa "pressão").

Se por um lado a formalização da estratégia e sua consequente representação pelo grafo confere uma estrutura a partir da qual se pode elaborar sessões de treinamento mais precisas, a formalização da dinâmica do jogo permite acessar com maior precisão o objetivo principal do processo de treinamento que é a orquestração coletiva. Além das restrições ao desempenho da equipe impostas pelo adversário, a 
orquestração coletiva pode ser limitada também pelas divergências de interpretação do contexto pelos próprios jogadores e, consequentemente, a seleção do próximo estado pode ser prejudicada. Logo, o foco do processo de treinamento é o desenvolvimento da orquestração coletiva frente aos conteúdos do planejamento proposto. A modelagem da dinâmica da oposição detalha os principais momentos do planejamento e da execução da estratégia nos quais a orquestração deve ocorrer.

$\mathrm{Na}$ interface $\mathrm{EST}_{\mathrm{M}}$ com o processo de treinamento, um desafio para pesquisas futuras é a elaboração e ensino de estratégias para esportes de campo grande que sejam tão completas quanto as estratégias para esportes de campo pequeno. A completude parece ser um critério adequado para comparar as estratégias, ou seja, estratégias mais completas são aquelas que possuem especificações para maior número de situações distintas da oposição. Para tanto, é preciso compreender melhor o limite da complexidade para que as especificações sejam viáveis, ou seja, os jogadores consigam orquestrá-las. Além disso, o aprofundamento do conhecimento sobre o processo de treinamento deverá contribuir para o entendimento dos fatores limitantes de aprendizagem que possam dificultar assimilação de planejamentos mais complexos, assim como os tempos de aprendizagem necessários.

A formalização da estratégia e da dinâmica do jogo tem também implicações para a análise do jogo. A mesma estrutura de decomposição dos conteúdos que suporta a estruturação de uma sessão de treinamento pode direcionar os focos de análise da oposição no jogo, com medidas em diferentes níveis de resolução, de ações individuais a jogadas coletivas. As estatísticas desse grande conjunto de medidas deve contribuir para a interpretação das causas de êxito ou fracasso frente ao adversário em diferentes circunstâncias de um jogo.

A informação gerada pela análise do jogo aumenta se o conhecimento sobre a estratégia do adversário também estiver disponível. A relevância do uso do grafo estratégico adversário na análise dos padrões gerados na oposição aponta para o problema complexo da inferência de estratégias de equipes a partir da observação do jogo. A abordagem desse problema estatístico complexo requer o uso do formalismo definido pelo $\mathrm{EST}_{\mathrm{M}} \mathrm{e}$, possivelmente, outras metodologias complementares que acessem a concepção do jogo das comissões técnicas de ambas as equipes por meio de pesquisas qualitativas que utilizem questionários semi-estruturados. A complementaridade de 
metodologias quantitativas e qualitativas para entendimento de um fenômeno que pode ser descrito fisicamente mas que, ao mesmo tempo, é desempenhado motivado por causas desconhecidas à observação externa se apresenta como um desafio científico dos mais interessantes, que alimenta debates em diversas áreas do conhecimento e que neste momento pôde ser formulado como um questionamento pertinente também nos ECIs.

Os desdobramentos da formalização proposta descritos acima indicam o impacto do modelo no entendimento de todo o processo competitivo, definido pelos seguintes elementos principais: i) elaboração da estratégia; ii) treinamento; iii) jogo; iv) análise do jogo. Este entendimento do processo competitivo é denominado ciclo de vida da estratégia, pois representa um sistema fechado, cuja causa primária para sua existência é o jogo mas cujos eventos são, em grande parte, delimitados pela estratégia concebida para orientar os comportamentos na oposição.

O ciclo de vida da estratégia possui a seguinte dinâmica. Na pré-temporada, levando em conta os jogadores disponíveis e outros aspectos como disponibilidade de tempo de treinamento a estratégia é elaborada. Após, as especificações são ensinadas ao longo das sessões de treinamento, no início de maneira mais geral e, a medida que ocorrem os jogos, de forma mais específica às características do próximo adversário. Desde o momento do jogo mas, principalmente após, é realizada a análise do jogo, que gera informações sobre os pontos fortes e fracos do desempenho da equipe. Estes dados são armazenados, alimentando um banco de dados que pode ser utilizado para a tomada de decisão da comissão técnica quanto a possíveis aperfeiçoamentos da estratégia planejada ou mesmo para subsidiar a decisão do sub-sistema a ser empregado no próximo jogo (i.e., SC-EST jogo seguinte). O ciclo de vida da estratégia é encerrado após o último jogo da temporada.

A definição dos elementos principais do processo competitivo em ECIs pelo ciclo de vida da estratégia torna mais precisa a noção dos potenciais focos de investigação para esse tipo de esporte. A ampliação do arcabouço teórico sobre cada um desses elementos pode constituir vasta linha de pesquisa para cientistas dedicados à temática dos esportes de invasão. O regulamento específico de cada ECI restringe o conjunto de habilidades motoras possíveis em cada um desses esportes. Assim, para que a modelagem desenvolvida possa ser aplicada a um esporte, os conteúdos específicos dos esportes devem ser levados em consideração. As classes de equivalência de 
dinâmicas ofensivas e defensivas definidas, assim como as possibilidades de desfecho da oposição a partir da execução dessas dinâmicas permite que as relações entre o modelo proposto e o processo de treinamento e a análise do jogo sejam estabelecidas. Até o momento, esta prática é bastante subjetiva nos meios profissionais, pois a estrutura de delimitação dos comportamentos não era evidente. E mesmo no basquetebol, esporte no qual as DCEs e DPEs foram definidas, há ainda possibilidades de novas investigações sobre $\mathrm{o}$ assunto. A taxionomia proposta contém os comportamentos ofensivos e defensivos referentes a criação e proteção do espaço, ou seja, vinculados à momentos de tentativa e eventual consumação de rupturas na oposição. Porém, em esportes como o próprio basquetenbol e ainda mais claramente em esportes como o futebol, uma sub-fase ofensiva que precede a ruptura é muito importante. Nesta sub-fase, denominada prospecção, que intuitivamente transmite a idéia de procura por espaço, há uma busca por oportunidades de ruptura ou, inversamente, redução de espaços para fortalecer a proteção da meta. Por exemplo, a equipe de futebol do Barcelona, que no período de 2010 a 2012 notabilizou-se pela conservação da bola e procura por espaços adequados (SEABRA, 2010), teve na utilização adequada desta fase do jogo um diferencial de seu desempenho. É através dessas classes de comportamentos que sessões de treinamento da equipe podem ser planejadas e conduzidas, nas quais ocorrerá o aprendizado da estratégia planejada, além de analisados em jogos da equipe. Portanto, as classes de comportamento constituem uma biblioteca de comportamentos que pode ser objetivamente consultada para definição das especificações estratégicas, conteúdos de treinamento e focos de análise do jogo. Trata-se de uma abordagem eficiente do grande universo de comportamentos que podem ocorrer em um jogo, limitando-os a um conjunto possível de se utilizar. A metodologia de concepção das DCEs e DPEs não encontra paralelo em outros esportes mas os resultados alcançados podem motivar iniciativas nessa direção. 


\section{CONCLUSÃO}

Os resultados da modelagem descrita nesta tese contribuem para traduzir objetivamente a complexidade do desempenho estratégico-tático nos ECIs, visando sua compreensão, explicação e predição. A utilização da teoria dos sistemas dinâmicos como arcabouço teórico para definição do fenômeno é consistente referencial para o progressivo aperfeiçoamento do modelo proposto.

Do ponto de vista aplicado, os resultados obtidos podem oferecer suporte metodológico para orientar treinadores em vários segmentos de suas atuações. Primeiro, no planejamento estratégico, por definir um método para desenho e análise de estratégias. Segundo, no treinamento de uma estratégia, pois os resultados da modelagem tornam objetiva a estrutura de decomposição dos conteúdos estratégicos, indicando como delimitar objetivos de treinamento com precisão. Finalmente, na análise do desempenho pois a integração da estratégia com a dinâmica do jogo e a definição dessa complexa estrutura contribui para que se compreenda quais podem ser os focos mais relevantes de análise da interação entre as equipes em um jogo.

Os modelos da estratégia e do jogo contribuem também para avanços tecnológicos que futuramente poderão impactar o processo de ensino-aprendizagem dos ECIs. Os resultados obtidos permitem, por exemplo, desenvolver pesquisas que levem à concepção de programas de computador capazes de auxiliar treinadores a desenharem suas estratégias. Além de editar as estratégias, este tipo de programa computacional poderá ser capaz de aplicar os delimitadores do $\mathrm{EST}_{\mathrm{M}}$ e os elementos da dinâmica da oposição, por exemplo, para requisitar propriedades topológicas essenciais e completar especificações parciais de caminhos em cada fase do jogo. Ainda, as classes de comportamentos ofensivas, defensivas e do confronto, instanciadas no basquetebol, poderão atuar como bibliotecas de possibilidades de comportamentos especificáveis em cada uma dessas situações planejadas na estratégia. Este ambiente de interatividade poderá contribuir para a formação do treinador, valendo-se do rigor metodológico para desenvolvimento de suas estratégias e das alternativas de interfaces tecnológicas atuais. Dessa forma, é possível divisar uma interessante linha de pesquisa relacionada à temática deste trabalho e inspirada na motivação inicial para realizá-lo, ou seja, proporcionar uma prática mais fundamentada e, consequentemente, de melhor qualidade nos diferentes níveis competitivos dos esportes coletivos. 


\section{REFERÊNCIAS BIBLIOGRÁFICAS}

ANGEL, G. M.; EVANGELOS, T.; ALBERTO, L. Defensive systems in basketball ball possessions. International Journal of Performance Analysis in Sport, v. 6, p. 98-107, 2006.

BARRIS, S. Automatic tracking and the analysis of human movement. International Journal of Performance Analysis in Sports, v. 8, n. 2, p.102-113, 2008.

BARRIS, S.; BUTTOM, C. A review of vision-based motion analysis in sport. Sports Medicine, v. 38, n. 12, p. 1025-1043, 2008.

BAYER, C. La enseñanza de los juegos desportivos colectivos. Barcelona, Hispano Europea, 1986.

BEETZ, M.; KIRCHLECHNER, B.; LAMES, M. Computerized real-time analysis of football games IEEE Pervasive Computing, v. 4, n. 3, p. 32-39, 2005.

BETRAN, J. O. De los juegos colectivos a los deportes de equipo. Apunts Educación Fisica y Deporte, v. 64, p. 3-4, 2001.

BETRAN, J. O.; CAMÍ, J. T. Genesis y etapas evolutivas del baloncesto como deporte contemporáneo. Tablas cronológicas (1891-1992). Apunts: Educacion Fisica e Deportes, v. 34, p. 6-42, 1993.

BOLSTAD, W. M. Introduction to Bayesian statistics. New Jersey, John Wiley and Sons, 2007.

BORRIE, A.; JONSSON, G. K.; MAGNUSSON, M. S. Temporal pattern analysis and its applicability in sport: an explanation and exemplar data. Journal of Sports Sciences, v. 20, n. 10, p. 845-852, 2002.

BOURBOUSSON, J.; SEVE, C.; MCGARRY, T. Space-time coordination dynamics in basketball: part 1. intra- and inter-couplings among player dyads. Journal of Sports Sciences, v. 28, n. 3, p. 339-347, 2010.

CANNON-BOWERS, J. A.; BOWERS, C. Applying work team results to sports teams: opportunities and cautions. International Journal of Sport and Exercise Psychology, v. 4, p. 363-369, 2006.

CARLING, C. Influence of oposition team formation on physical and skill-related performance in a professional soccer match. European Journal of Sport Science, v. 11, n. 3, p. 155-164, 2011.

CARLING, C.; BLOOMFILED, J.; NELSEN, L.; REILLY, T. The role of motion analysis in elite soccer. Sports Medicine, v. 38, n. 10, p. 839-862, 2008. 
CRUZ, J. ; TAVARES, F. Notational analysis of the offensive patterns in cadets basketball teams in Hughes, M. and Tavares, F. (Ed.), Notational Analysis of Sport IV. Proceedings of the IV World Congress (pp. 112-119). Oporto, Portugal: FCDEFUP. , 1998.

DUMANGANE, M.; ROSATI, N.; VOLOSSOVITCH, A. Departure from independence and stationarity in a handball match. Journal of Applied Statistics, v. 36, n. 7, p. 723-741, 2009.

ERIKSSON, H. E.; PENKER, M. Business Modeling with UML: business patterns at work. New York, John Wiley and Sons, 2000.

FIORE, S. M.; SALAS, E. Team cognition and expert teams: developing insights from cross-disciplinary analysis of exceptional teams. International Journal of Sport and Exercise Psychology, v. 4, n. 369-375, p., 2006.

FONSECA, R. P.; SALLES, J. F.; PARENTE, M. A. M. P. Development and content validity of the brazilian brief neurophysiological assessment battery neupsilin. Psychology and Neuroscience, v. 1, n. 1, p. 55-62, 2008.

FRANKS, I.; MILLER, G. Eyewitness testimony in sport. Journal of Sport Behavior, v. 9, p. 38-45, 1986.

FU, K. S. Syntactic Methods in Pattern Recognition. New York, Academic Press, 1974.

GREHAIGNE, J. F.; BILLARD, M.; GUILLON, R. ; ROCHE, J. Vers une autre conception de l'enseignement des sports collectifs in Méthodologie et Didactique de I'EPS, Clermond-Ferrand: Editions AFRAPS, 1988.

GREHAIGNE, J. F.; BOUTHIER, D.; DAVID, B. Dynamic-system analysis of opponent relationships in collective actions in soccer. Journal of Sports Sciences, v. 15, n. 2, p. 137-149, 1997.

GREHAIGNE, J. F.; CATY, D. G. Modelling ball circulation in invasion team sports: a way to promote learning games through understanding. Physical Education and Sport Pedagogy, v. 15, n. 3, p. 257-270, 2010.

GREHAIGNE, J. F.; GODBOUT, P. Tactical knowledge in team sports from a constructivist and cognitivist perspective. Quest, v. 47, p. 490-505, 1995.

GREHAIGNE, J. F.; GODBOUT, P.; BOUTHIER, D. The foundations of tactics and strategy in team sports. Journal of Teaching in Physical Education, v. 18, p. 159-174, 1999. 
GREHAIGNE, J. F.; LAROCHE, J. Y. Quelques fondements et présupposés theoriques d'une démarche [some theoretical bases and assumptions of an approach] EPS Dossier v. 17, p. 12-15, 1994.

HUGHES, M.; BARTLETT, R. The use of performance indicators in performance analysis. Journal of Sport Sciences, v. 20, p. 739-754, 2002.

JAMES, N.; TAYLOR, J.; STANLEY, S. Reliability procedures for categorical data in performance analysis. International Journal of Performance Analysis in Sport, v. 7, p. 1-11, 2002.

KLAASSEN, F.; MAGNUS, J. Are points in tennis independent and identically distributed? Evidence from a dynamic binary panel data model. Journal of American Statistical Association, v. 96, p. 1-26, 2001.

KRAUSE, J.; PIM, R. Coaching Basketball. New York, McGraw Hill, 2002.

LAMAS, L.; DE ROSE JR., D.; SANTANA, F.; ROSTAISER, E.; NEGRETTI, L.; UGRINOWITSCH, C. Space creation dynamics in basketball offence: validation and evaluation of elite teams International Journal of Performance Analysis in Sports, v. 11, p. 71-84, 2011.

LAMES, M. Modelling the interaction game sports: relative phase and moving correlation. The 8th Australasian Conference on Mathematics and Computers in Sport, p. 556-560, 2006.

LAMES, M.; HANSEN, G. Designing observational systems to support top-level teams in game sports. International Journal of Performance Analysis in Sports, v. 1, n. 1, p. 83-90, 2001.

LAMES, M.; MCGARRY, T. On the search for reliable performance indicators in game sports. International Journal of Performance Analysis in Sport, v. 7, n. 1, p. 62-79, 2007.

LANDIS, J. R.; KOCH, G. G. The measurement of observer agreement for categorical data. Biometrics, v. 33, p. 159-174, 1977.

LEBED, F. A dolphin only looks like a fish: players' behavior analysis is not enough for game understanding in the light of systems approach - a response to the reply by McGarry and Franks European Journal of Sport Science, v. 7, n. 1, p. 55-62, 2007.

MAHLO, F. O Acto Táctico no Jogo. Lisboa, Compendium, 1969.

MCGARRY, T.; ANDERSON, D. I.; WALLACE, S. A.; HUGHES, M. D.; FRANKS, I. M. Sport competition as a dynamical self-organizing system. Journal of Sports Sciences, v. 20, n. 10, p. 771-781, 2002. 
MCGARRY, T.; FRANKS, I. In search of invariant athletic behaviour in sport: an example from championship squash match-play. Journal of Sports Sciences, v. 14, n. 5, p. 445-456, 1996.

MCPHERSON, S. Expert-novice differences in performance skills and problem representations of youth and adults during tennis competition. Research Quarterly for Exercise and Sport, v. 70, n. 3, p. 233-263, 1999a.

MCPHERSON, S. Tactical differences in problem representations and solutions in collegiate varsity and beginner female tennis players. Research Quarterly for Exercise and Sport, v. 70, n. 4, p. 369-384, 1999b.

MCPHERSON, S. Expert-novice differences in planning strategies during collegiate singles tennis competition Journal of Sport and Exercise Psycholgy, v. 22, p. 39-62, 2000 .

MEXAS, K.; TSITSKARIS, G.; KYRIAKOU, D.; GAREFIS, A. Comparison of effectiveness of organized offenses between two different championships in high level basketball. International Journal of Performance and Game Analysis, v. 5, n. 1, p. $72-82,2005$.

NESTKE, A. Action chains, relations, and rates: a conceptual framework and mathematical model for the analysis of sport games. International Journal of Performance Analysis in Sport, v. 4, n. 1, p. 4-22, 2004.

ODONOGHUE, P. Reliability issues in performance analyis. International Journal of Performance Analysis in Sports, v. 7, n. 1, p. 20-27, 2007.

OGATA, K. Discrete-time Control Systems. Englewood Cliffs (NJ), Prentice Hall, 1986.

OKAZAKI, V. H. A.; RODACKI, A. L. F.; DEZAN, V. H.; SARRAF, T. A. Coordenação do arremesso de jump no basquetebol de crianças e adultos. Revista Brasileira de Biomecânica, v. 7, p. 15-22, 2006.

PASSOS, P.; ARAUJO, D.; DAVIDS, K.; GOUVEIA, L.; MILHO, J.; SERPA, S. Information-governing dynamics of attacker-defender interactions in youth rugby union. Journal of Sports Sciences, v. 26, n. 13, p. 1421-1429, 2008.

PASSOS, P.; MILHO, J.; FONSECA, S.; BORGES, J.; ARAUJO, D.; DAVIDS, K. Interpersonal distance regulates functional grouping tendencies of agents in team sports. Journal of Motor Behavior, v. 43, n. 2, p. 155-163, 2011.

PEDERSEN, H. K.; COOKE, N. J. From battle plans to football plays: extending military team cognition to football. International Journal of Sport and Exercise Psychology, v. 4, p. 422-446, 2006. 
PERS, J.; BON, M.; KOVACIC, S. Observation and analysis of large-scale human motion Human Movement Science, v. 21, p. 295-311, 2002.

PERSE, M.; KRISTAN, M.; KOVACIC, S.; VUCKOVIC, G.; PERS, J. A trajectorybased analysis of coordinated team activity in a basketball game. Computer Vision and Image Understanding, v. 113, n. 5, p. 612-621, 2009.

PHILLIPS, D. Evolution of international basketball rules and their effect upon the game. Faculty of Springfield College. Springfield, MA, Springfield College. PhD: 308.(1990)

REFOYO, I.; DOMINGUEZ, J.; SAMPEDRO, J.; DEL CAMPO, J. Análisis de la decisión táctica en el bloqueo directo: una comparación entre selecciones internacionales absolutas y clubes. . Cuardernos de Psicologia del Deporte, v. 9, n. Suplemento 1, p., 2009.

REIMER, T.; PARK, E. S.; HINSZ, V. B. Shared and coordinated cognition in competitive and dynamic task environments: an information-processing perspective for team sports. International Journal of Sport and Exercise Psychology, p. 376-400, 2006.

REMMERT, H. Analysis of group tactical offensive behavior in elite basketball on the basis of a process oriented model. European Journal of Sport Science, v. 3, n. 3, p. 1$14,2003$.

RENTSCH, J. R.; DAVENPORT, S. W. Sporting a new view: team member schema similarity in sports. International Journal of Sport and Exercise Psychology, v. 4, p. 401-421, 2006.

RIERA, J. R. Estrategia, táctica y técnica deportivas. Apunts, v. 39, p. 45-56, 1995.

ROMERO, J. Análisis de la decisión táctica en deportes colectivos: una aplicación al bloqueo directo en baloncesto. Madrid, Universidad Politécnica de Madrid. PhD: 247.(2010)

SAMPEDRO, J. Fundamentos de la Táctica Deportiva. Gymnos Editorial, Madrid, 1999.

SEABRA, A.; DANTAS, L. E. P. B. T. Space definition for match analysis in soccer International Journal of Performance Analysis in Sports, v. 6, n. 2, p. 97-113, 2006.

SEABRA, F. Identificação e análise de padrões de circulação da bola no futebol. Departamento de Esporte. São Paulo, Universidade de São Paulo. Mestrado.(2010)

SILVA, J. C. Analysis of basketball structure and the output in male junior teams in Hughes, M. and Tavares, F. (Ed.), Notational Analysis of Sport IV. Proceedings of the IV World Congress (pp. 120-122). Oporto. Portugal:FCDEF-UP, 1998. 
SMITH, D.; SPEAR, B. Multiple Offense and Defense, Prentice Hall Trade, 1981.

THORPE, R.; BUNKER, D.; ALMOND, L. Rethinking Games Teaching. Loughborough, Loughborough University of Technology, 1986.

TSAMOURTZIS, E.; KARYPIDIS, A.; ATHANASIOU, N. Analysis of fast breaks in basketball. International Journal of Performance Analysis in Sport, v. 5, n. 17, p. 17-22, 2005.

WARD, P.; ECCLES, D. W. A commentary on "team cognition and expert team": emerging insights into performance for exceptional team". International Journal of Sport and Exercise Psychology, v. 4, p. 463-483, 2006.

WINTER, F. The Triple Post Offense. Englewood Cliffs, N.J., Prentice-Hall, 1962.

WOODEN, J. Practical Modern Basketball. New York, Ny, The Ronald Press Company, 1966. 